\title{
Properties and acid risk assessment of soils in two parts of the Cherry River watershed, West Virginia
}

\author{
Cara L. Sponaugle \\ West Virginia University
}

Follow this and additional works at: https://researchrepository.wvu.edu/etd

\section{Recommended Citation}

Sponaugle, Cara L., "Properties and acid risk assessment of soils in two parts of the Cherry River watershed, West Virginia" (2005). Graduate Theses, Dissertations, and Problem Reports. 2227. https://researchrepository.wvu.edu/etd/2227

This Thesis is protected by copyright and/or related rights. It has been brought to you by the The Research Repository @ WVU with permission from the rights-holder(s). You are free to use this Thesis in any way that is permitted by the copyright and related rights legislation that applies to your use. For other uses you must obtain permission from the rights-holder(s) directly, unless additional rights are indicated by a Creative Commons license in the record and/ or on the work itself. This Thesis has been accepted for inclusion in WVU Graduate Theses, Dissertations, and Problem Reports collection by an authorized administrator of The Research Repository @ WVU. For more information, please contact researchrepository@mail.wvu.edu. 


\title{
Properties and Acid Risk Assessment of Soils in Two Parts of the Cherry River Watershed, West Virginia
}

\author{
Cara L. Sponaugle \\ Thesis submitted to the \\ Davis College of Agriculture, Forestry, and Consumer Sciences \\ at West Virginia University \\ in partial fulfillment of the requirements for the degree of \\ Master of Science \\ in \\ Plant and Soil Sciences \\ Jeff Skousen, Ph.D., Chair \\ John Sencindiver, Ph.D. \\ James Thompson, Ph.D. \\ Pamela Edwards, Ph.D. \\ Division of Plant and Soil Sciences
}

Morgantown, West Virginia 2005

Keywords: soil acidification, acid deposition, Ca:Al molar ratio, forest soils 


\begin{abstract}
Properties and Acid Risk Assessment of Soils in Two Parts of the Cherry River Watershed, West Virginia
\end{abstract}

Cara L. Sponaugle

The Cherry River watershed project area is underlain by acid-forming geology. The objectives of this study were to determine the physical and chemical properties of the soils, classify the soils, and to assess the acid risk to the forests. Sixty-seven soil pedons were sampled by horizon across six landscape positions and the soil samples were analyzed. The soils of the watershed were all acid. The east area soils were more acid than the west area soils. The shoulder soils showed the highest risk and the floodplain soils showed the lowest risk of forest productivity decline. While both areas showed high acidification and forest productivity risk, the east area soils have higher risk for forest productivity decline in the future. While a few forest regeneration failures are known to have occurred after harvesting in this area, further acidification potentially will reduce the regeneration of a marketable timber stand. 


\section{Acknowledgments}

There are several people who deserve thanks for the help that they have given me on this project.

To start, I would like to thank my committee: Dr. Jeff Skousen, Dr. John Sencindiver, Dr. James Thompson, and Dr. Pamela Edwards. This project would have never become what it did without the guidance and support of all of you.

I would like to thank Stephanie Connolly for taking me under her wing at the Forest Service and for giving me the opportunity to work and learn under her guidance. It has been a pleasure and hopefully will continue.

I would like to thank the staff of the Monongahela National Forest for all of the help and training that I have received while working with them. A special thanks goes to the GIS staff for all the patience that was needed to put up with me.

Pam and Freddie.

You took me in and welcomed me into your home for two summers. I can never thank the two of you enough.

Mom and Dad.

Everything that I have ever accomplished is due to you. You two have been my role models, support group, and the heros of my life.

Derek.

My fiancé. I never would have been able to do this without you. You have given me the best gift, your love and support. You took care of me when I was too busy and stressed out to do so myself.

Sara.

All I have to say is thanks for being there and you know all the rest. 


\section{TABLE OF CONTENTS}

$\underline{\text { Page }}$

Chapter 1. Introduction, Literature Review, Materials and Methods ...........1

Introduction................................................................. 1

Literature Review...........................................................4

An Overview of Forest Productivity .....................4

Acid Deposition .................................................6

Soil Acidification.................................................. 9

Ca:Al Molar Ratio.............................................11

Tree Response to Soil Acidification ......................13

Materials and Methods.....................................................14

Project Area Description......................................14

Field and Laboratory Methods............................23

Chapter 2. Physical Soil Properties............................................................30

Results and Discussion ................................................ 30

East versus West Areas ..........................................30

Landscape Positions...............................................31

East Area ....................................................31

West Area....................................................32

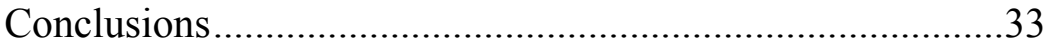

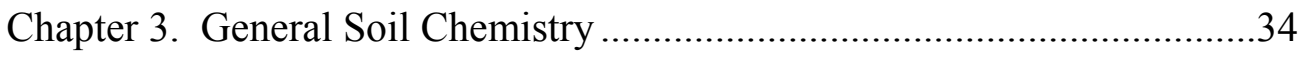

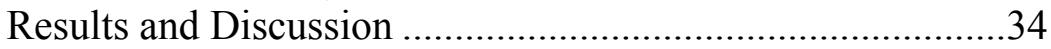

East versus West Areas ............................................34

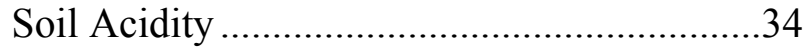

Base Cations................................................37

Acid Cations..................................................38

Carbon and Nitrogen.................................40

Landscape Positions...........................................41

East Area ....................................................41

Soil Acidity ......................................41

Base Cations.....................................42

Acid Cations.......................................43

Carbon and Nitrogen........................44

West Area.................................................45

Soil Acidity .......................................45

Base Cations.....................................46

Acid Cations......................................47

Carbon and Nitrogen.........................48

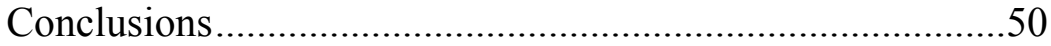

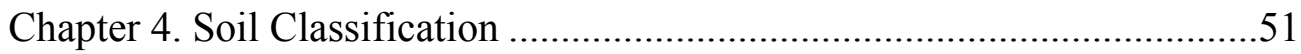


Chapter 5. Acid Risk Assessment and Management Implications ...............53

Acid Risk Assessment.........................................................53

East versus West Areas ............................................54

Landscape Positions...............................................55

Risk by Soil Pit ...................................................56

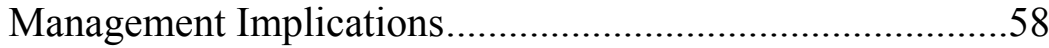

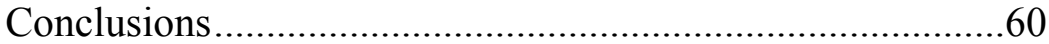

Chapter 6. Bibliography .....................................................................62

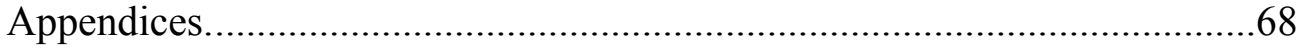

Appendix A. Soil Description Guidelines ...................................68

Appendix B. Full Characterization Profile Descriptions .................69

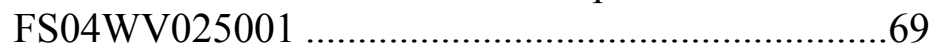

FS04WV025002 ….............................................. 71

FS04WV025003 ....................................................73

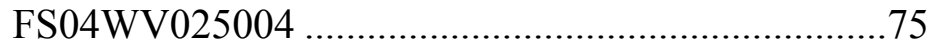

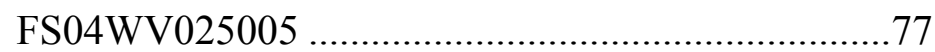

FS04WV025010 …..............................................79

FS04WV025019 ….............................................81

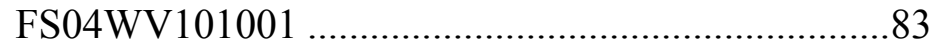

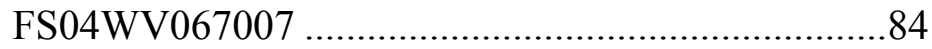

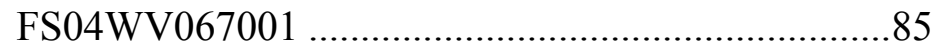

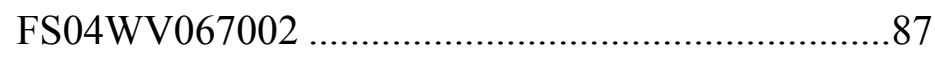

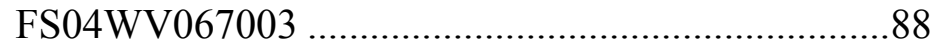

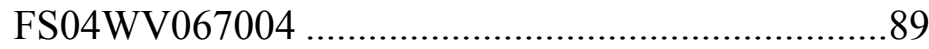

FS04WV067005 ….............................................91

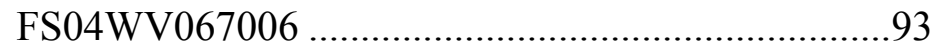

FS04WV067017 ….............................................95

Appendix C. Satellite Pit Descriptions ........................................96

Appendix D. Physical Properties Data..........................................122

Appendix E. Acidity and buffering Data ....................................130

Appendix F. Base Cation Data.........................................................138

Appendix G. Acid Cation Data ..................................................146

Appendix H. Carbon and Nitrogen Data........................................154

Appendix I. Acid Risk Data.........................................................162 


\section{LIST OF TABLES}

Table 1.1. General section of the Pottsville Group for the project areas of the Cherry River watershed (from Price, 1939) 15

Table 1.2. Soil mapping units for the projects areas of the Cherry River watershed

Table 1.3. Water quality data from several streams in the Cherry River watershed.

Table 1.4. A comparison of soils, tree types, geology, and precipitation information between the east and west project areas......

Table 1.5. Landscape positions by project area .25

Table 2.1. Mean texture and bulk density data for the soils by horizon for east and west areas

Table 2.2. Texture and bulk density data for east area landscape positions

Table 2.3. Texture and bulk density data for west area landscape positions

Table 3.1. Acidity parameters by horizon compared between watershed areas.

Table 3.2. Mean base cation concentrations by horizon compared between watershed areas...................................................38

Table 3.3. Mean acid cation concentrations by horizon compared between watershed areas

Table 3.4. Mean carbon and nitrogen by horizon compared between watershed area.

Table 3.5. Mean soil acidity parameters for the east area landscape positions

Table 3.6. Mean base cation concentrations for the east area landscape positions

Table 3.7. Mean acid cation concentrations for the east area landscape positions 
Table 3.8. Mean carbon and nitrogen for the east area landscape positions

Table 3.9. Mean soil acidity parameters for the west area landscape positions

Table 3.10. Mean base cation concentrations for the west area landscape positions

Table 3.11. Mean acid cation concentrations for the west area landscape positions .48

Table 3.12. Mean carbon and nitrogen for the west area landscape positions

Table 4.1. Subgroup classification and family classes for the Cherry River watershed soils

Table 5.1. Thresholds used for risk assessment in the Cherry River watershed

Table 5.2. The soil acidification parameters used for the acid risk assessment of the soils in Cherry River watershed for the east and west project areas by horizon.

Table 5.3. Risk to forest productivity by landscape position based on $\mathrm{Ca}: \mathrm{Al}$ molar ratios and \% BSECEC in the upper B horizon

Table 5.4. The percentages of soil pits for each level of risk in each project area. Risk assessment was based on the upper B horizon data. 


\section{LIST OF FIGURES}

Figure 1.1. The location of the Cherry River watershed within

the Monongahela National Forest in West Virginia. 2

Figure 1.2. Project areas within the Cherry River watershed. 3

Figure 1.3. Total nitrogen deposition from 1989 to 2003 at Cedar Creek, WV......

Figure 1.4. Total sulfur deposition from1989 to 2003 at Cedar Creek, WV. 8

Figure 1.5. Elevation map of the Cherry River watershed. 19

Figure 1.6. Wet sulfate deposition for the Cherry River watershed.

Figure 1.7. Location of streams sampled in the Cherry River watershed.

Figure 1.8. Landscape positions on which soils were sampled. .24

Figure 1.9. Soil pit locations on the Cherry River watershed in West Virginia.

Figure 3.1. The relationship between soil $\mathrm{pH}$ and effective cation exchange capacity (ECEC). .36

Figure 3.2. Soil $\mathrm{pH}$ with depth for both project areas................................37

Figure 3.3. The iron and aluminum content of the soils in relation to soil $\mathrm{pH}$..... .40

Figure 5.1. The acid risk by soil sampling location. .57 


\section{Chapter 1. \\ Introduction, Literature Review, Materials and Methods}

\section{Introduction}

Acid deposition has played a large role in the acidification of soils in the eastern United States (Binkley et al., 1998). The Monongahela National Forest (MNF) lies downwind of many industries that produce the highest sulfur dioxide emissions in the nation, including those within Ohio, Pennsylvania, Indiana, Illinois, and West Virginia (NADP, 2005). In addition to high deposition of these emissions, the low buffering capacities of certain geologies and soils on the forest have led to increased acidity in streams and possible nutrient depletion of soils (Connolly et al., 2004).

The Cherry River watershed, which lies within the Monongahela National Forest in West Virginia (Figure 1.1), has some of the highest rates of acid deposition in the state (NADP-NRSP-3, 2005). The eastern portion of the watershed has higher loadings of deposition and transitions to lower loads in the western portion of the watershed. Streams on the eastern side show an average $\mathrm{pH}$ of 4.7 and acid neutralizing capacity (ANC) of $-16.1 \mu \mathrm{eq} \mathrm{L}^{-1}$, while streams on the western side have an average $\mathrm{pH}$ of 5.8 and ANC of $4.0 \mu \mathrm{eq} \mathrm{L} \mathrm{L}^{-1}$. This watershed also lies on the Pottsville geology, which is characterized by high moisture, acidic conditions, and low nutrient levels (Rice et al., 1992). The high acid deposition loads combined with acidic geology make the Cherry River watershed an area of concern for soil acidification and nutrient depletion especially with regard to conducting land management activities. 


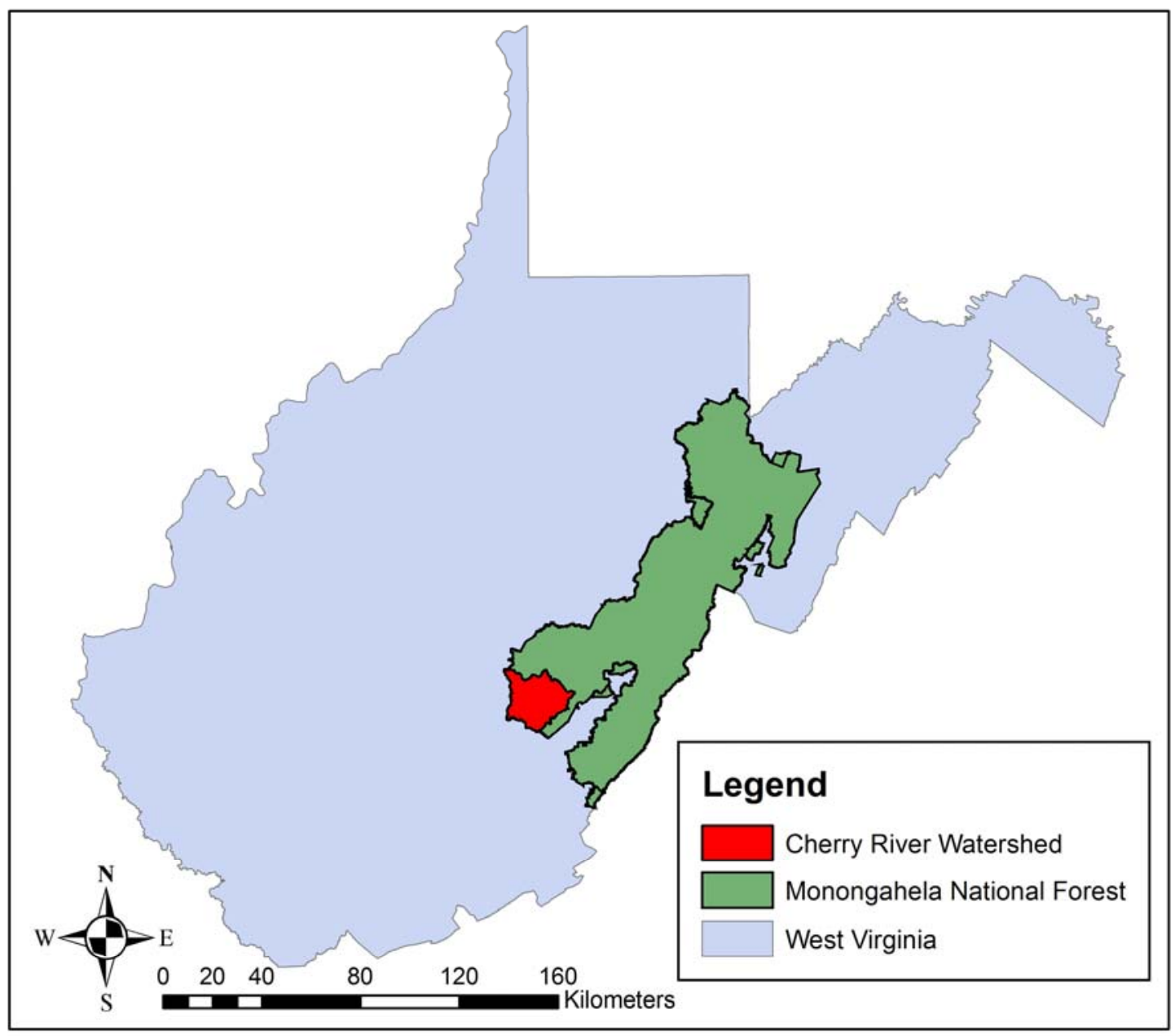

Figure 1.1. The location of the Cherry River watershed within the Monongahela National Forest in West Virginia.

It is important to identify soil acidification parameters that can assist in management decisions for forests throughout the East, particularly for those states that have large forest-based industries. For example, West Virginia forests are a source of over $\$ 4.2$ billion dollars annually: $\$ 3.2$ billion from wood products and $\$ 1$ billion from forest-based tourism. In 1995, one billion board feet were harvested in West Virginia and annual growth still exceeded annual harvests (Adams et al., 2000). 
The objectives of this project were to determine the physical and chemical properties of the soils of the two project areas (Figure 1.2), to classify the soils to the Subgroup level of taxonomy, and to evaluate the differences in soils between the two areas. Acid risk to forest productivity and sustainability was determined using the $\mathrm{Ca}: \mathrm{Al}$ molar ratio and base saturation of the effective cation exchange capacity (BSECEC) and compared among watershed areas, landscape positions, and sampling sites.

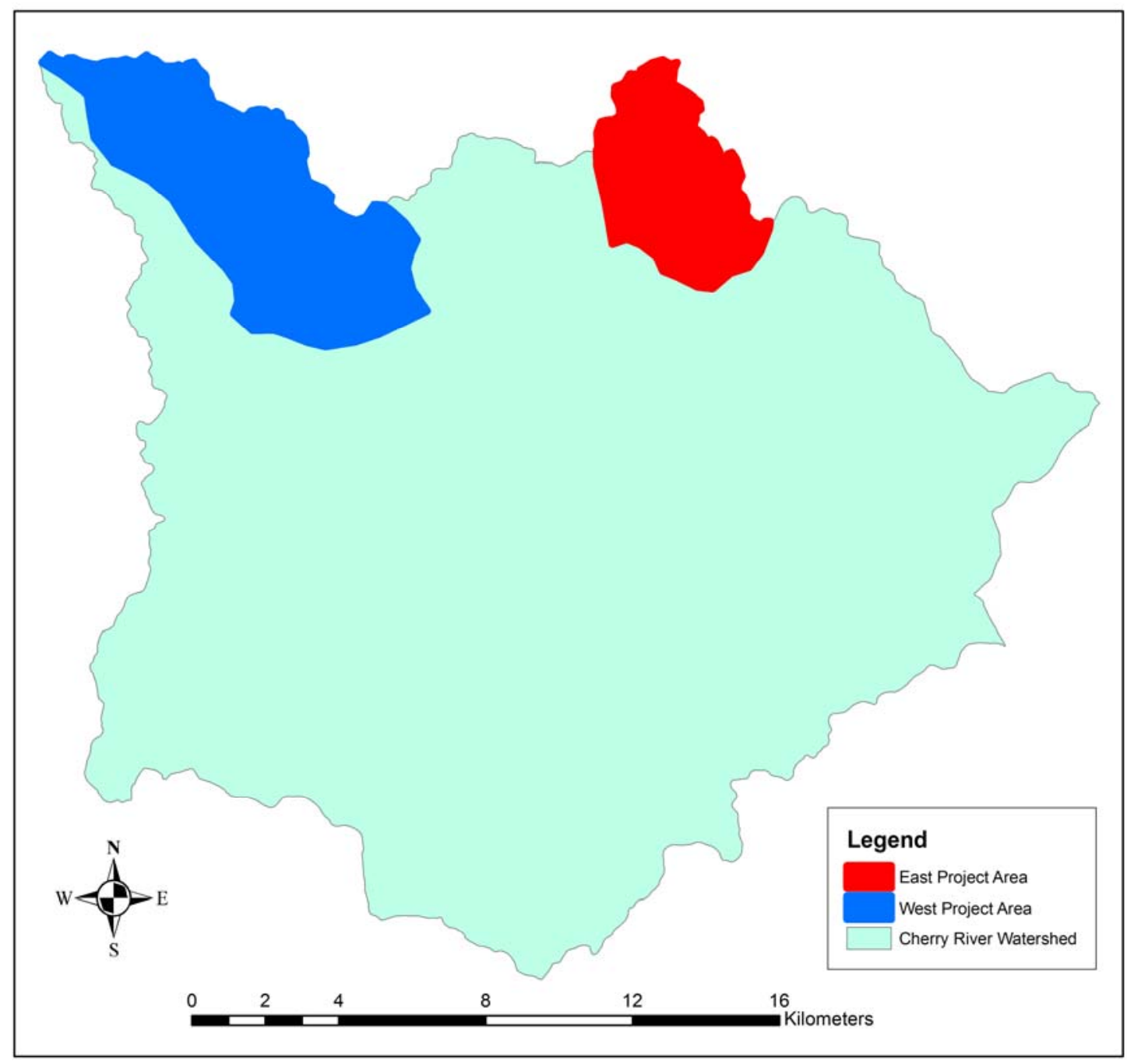

Figure 1.2. Project areas within the Cherry River watershed. 


\section{Literature Review}

\section{An Overview of Forest Productivity:}

Forest productivity and sustainability have been issues of concern in recent years. Forest health decline and decreasing species diversity have been observed across North America and Europe (Binkley et al., 1998). Forest productivity throughout eastern United States and Canada has been declining for the past several decades (Bailey et al., 2004). Several factors influence the productivity and sustainability of forests, including disease, insect infestations, soil moisture, nutrient status, and acidic deposition. These factors rarely act independently, but more often are interrelated (Binkley et al., 1998; Duchesne et al., 2003). For example, nutrient availability for forest trees can be affected deleteriously in areas subject to chronic, high levels of acidic deposition, which in turn can make those same trees susceptible to diseases or insect damage. Federer et al. (1989) stated "continual depletion of the total amount of any nutrient must sooner or later decrease its availability and, consequently, forest productivity." Thus, soil chemistry can play a key role in overall forest health, both directly and indirectly.

Some soil chemical factors that affect forest health and sustainability relative to acidic deposition are base cations (calcium, magnesium, potassium, sodium), effective cation exchange capacity, nutrient availability, acidity, nitrogen and sulfate saturation, and toxic metals, including aluminum and manganese (Adams et al., 2000). Base cations are important to sustaining forest health because they are macronutrients; calcium is particularly important because it is the primary component of bole wood. Base cations also aid in neutralizing soil acidity, thereby making other nutrients more available to forest vegetation. 
The main inputs of calcium to soils are weathering, litter fall, and atmospheric deposition (Huntington, 2000). However, the rate at which calcium is replaced by weathering tends to be very slow compared to rates of deposition, uptake, and leaching (USGS, 1999). Schnably (2003) found that the potential replenishment of soil calcium in Appalachia is low due to the highly weathered status of these soils. Soils most susceptible to calcium depletion are older soils that form from base-poor geology. Soils derived from limestone and dolomitic bedrock are the least susceptible to calcium depletion (Huntington et al., 2000).

Specific criteria need to be established for the assessment of forest ecosystem impacts on localized scales. Holmberg et al. (2001) stated, "In general, it would be easier to use a criterion concerning the behaviour of the system as a whole, rather than one isolated feature, such as forest health. The fact that the link between forest health and changes in soil variables is ambiguous supports the use of a simpler criterion, relating to a higher level in the system hierarchy."

Several soil chemical factors, including Ca:Al molar ratio and base saturation, have been related to soil nutrient condition, with fewer of these factors related to forest health. Cronan and Grigal (1995) noted that base saturation of the effective cation exchange capacity (BSECEC) of $\leq 15 \%$ typically is associated with some level of forest decline. However, while relationships have been found, threshold values for each across various situations (i.e., climate, topographic, deposition, soil conditions, bedrock/parent material, physiography, etc.) have not been identified. Consequently, threshold values or at least levels of concern need to be defined regionally or more broadly to model and predict forest productivity (Federer et al., 1989). 


\section{Acid Deposition}

By the 1950s, acid deposition was thought to be widespread across the northeastern United States (Bailey et al., 2005). The largest contributors to acid deposition are fossil fuel burning power generation plant emissions (EPA, 1998). Acid deposition is formed when sulfur dioxide and nitrogen oxides react with water and oxygen in the atmosphere to form acidic compounds (EPA, 1998). These compounds then fall to the earth in either dry or wet forms as sulfuric and nitric acids. Sixty percent of the precipitation acidity in United States is from sulfuric acid (Sparks, 2003). Nitric acid makes up the majority of the other 40 percent of precipitation acidity. Acidic compounds are only some of the ions in atmospheric deposition. Others include calcium $(\mathrm{Ca})$, magnesium $(\mathrm{Mg})$, potassium $(\mathrm{K})$, sodium $(\mathrm{Na})$, ammonium $\left(\mathrm{NH}_{4}\right)$, and chloride $(\mathrm{Cl})$.

There are three sites in WV that participate in the National Atmospheric Deposition Program (NADP) that monitor wet deposition inputs: Babcock State Park operated by United States Geologic Service (USGS), Cedar Creek State Park operated by United States Environmental Protection Agency (USEPA), and Parsons operated by the US Forest Service, Northeastern Research Station. Only Cedar Creek and Parsons participate in dry deposition collections in USEPA's Clean Air Status and Trends Network (CASTNET). The closest site collecting both wet and dry deposition data to Cherry River is the Cedar Creek State Park site. The 2004 annual mean rates of wet nitrogen $(\mathrm{N})$ and sulfate $\left(\mathrm{SO}_{4}\right)$ deposition for Cedar Creek State Park were $12.0 \mathrm{~kg} \mathrm{ha}^{-1}$ and $18.5 \mathrm{~kg} \mathrm{ha}^{-1}$, respectively (NADP, 2005). Figures 1.3 and 1.4 show the deposition trends (wet and dry) for the Cedar Creek site from 1989 to 2003. USEPA identified the 
Mid-Appalachian region, including WV, to be a sensitive region in their 1998 National Air Quality and Emissions Trend Report, even though deposition of nitrogen and sulfur compounds in this region have been decreasing since the mid 1990s (EPA, 1998).

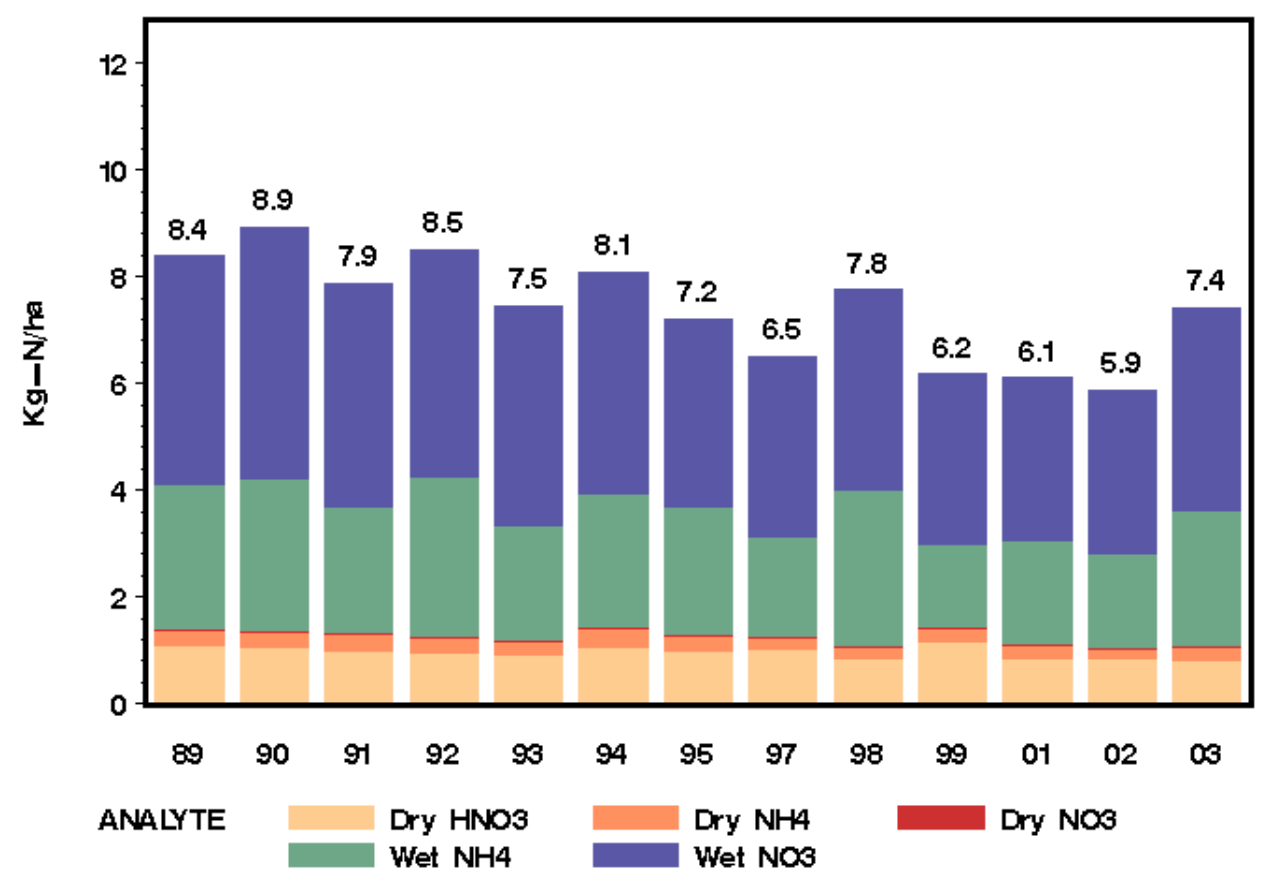

Figure 1.3. Total nitrogen deposition from 1989 to 2003 at Cedar Creek, WV (from CASTNET/NADP-NTN). 


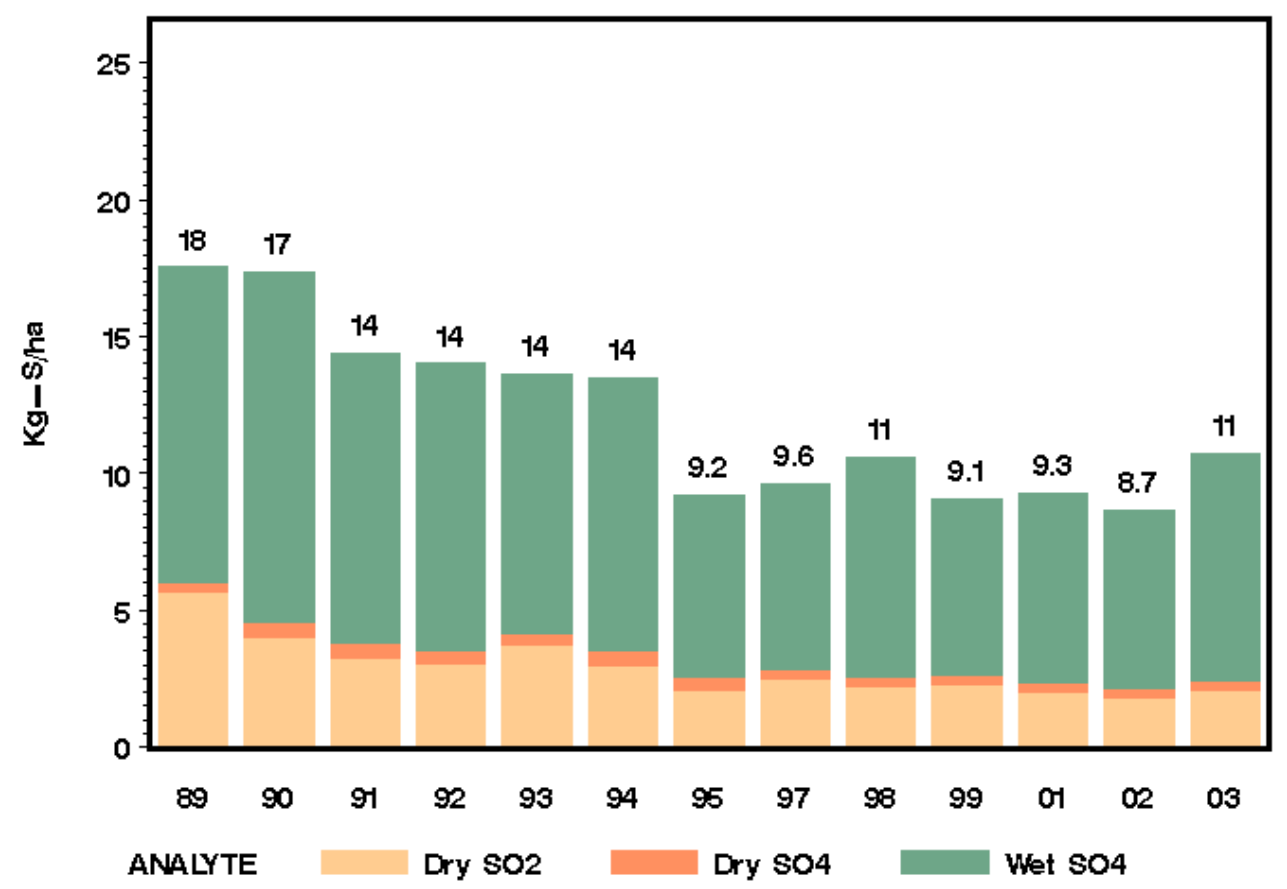

Figure 1.4. Total sulfur deposition from 1989 to 2003 at Cedar Creek, WV (from CASTNET/NADP-NTN).

As shown by Figures 1.3 and 1.4, the total sulfur deposition has decreased by nearly half from 1989 to 2003 due to emission controls that have been set by legislation (EPA, 1998). However, total nitrogen deposition has remained at relatively steady levels for the same time period.

Decreases in the emissions of sulfate and nitrogen oxides were expected to slow acidification of soils and water; however, emissions of base cations, which neutralize the acids, also declined. The annual mean rate of wet base cation deposition in 2004 at Cedar Creek State Park was $2.1 \mathrm{~kg} \mathrm{ha}^{-1}$, which translated to base cation deposition being over 10 times less than acidic anion deposition (NADP, 2005). Therefore, even with the decreases in deposition, the net result was that acidic inputs to soil and water increased. 


\section{Soil Acidification}

In the soil, hydrogen ions dissociate from the sulfate and nitrate ions initially deposited as sulfuric and nitric acids. The dissociated hydrogen ions provide acidity to the soil, which results in $\mathrm{pH}$ decreases (Sparks, 2003). The addition of $\mathrm{H}^{+}$into the soils by acid deposition further results in soil acidification by displacing base cations from soil exchange sites (Sparks, 2003), as illustrated below using calcium in the example:

$$
2 \mathrm{H}^{+}+\mathrm{SO}_{4}{ }^{2-}+\mathrm{Ca}^{2+} \text { (on exchange sites) } \rightarrow \mathrm{Ca}^{2+}+\mathrm{SO}_{4}{ }^{2-}+2 \mathrm{H}^{+} \text {(on exchange sites) }
$$

Upon becoming displaced from soil exchange sites, base cations pair with sulfate or nitrate anions to maintain the electroneutrality of the soil solution and can be leached from the soil by subsurface water moving laterally or vertically. Often the result is increased leaching losses to streams so that base cations are permanently lost from watershed soils. As base cations become depleted, additional hydrogen ion inputs release acidic cations from the soil, principally aluminum (Al), but also other metals such as manganese (Mn) and iron (Fe) (Bache, 1986).

Soil acidification reflects an increase of acid cations accompanied by a decrease in base cations (Yanai, 2005). While soil weathering, soil biotic processes, and vegetative uptake are naturally-acidifying processes (Gbondo-Tugbawa and Driscoll, 2003 ) and acid deposition explains only about $38 \%$ of acidic input to ecosystems (Markewitz et al., 1998), there is evidence that acidic deposition has accelerated acidification of some soils. For example, a study of soil acidification in the upper $60 \mathrm{~cm}$ of soil in the Calhoun Experimental Forest in South Carolina has shown an accelerated rate of acidification caused by atmospheric deposition from 1962 to 1990 (Markewitz et al., 1998). In England, Blake et al. (1999) determined from a century-long study that 
acidic deposition was the main cause of soil acidification in the Geescroft Wilderness and acid deposition had greatly accelerated soil acidification. Calcium has leached at double the natural rate in forests affected by acid deposition (Joslin et al., 1992). If leaching continues at current rates, it is thought that in 150 years there will only be enough calcium in the soil for one hardwood rotation to reach marketable size in the Panola Mountain watershed in Georgia (USGS, 1999). From a model simulation, GbondoTugbawa and Driscoll (2003) found that there has been 20\% depletion of soil calcium over the past 40 years in the Hubbard Brook Experimental Forest in New Hampshire.

Acidification of soils increases cation leaching, decreases soil $\mathrm{pH}$ and base saturation, and negatively affects many biological processes (Adams and Kochenderfer, 1998). Adams and Kochenderfer (1998) found that the nitrogen content in trees increased from the artificial acidification of forest soils. In another study, Adams (1999) found that calcium losses were particularly large when a forest soil was artificially acidified compared to a non-forest soil. A nine-year acidification study at Bear Brook watershed in Maine found accelerated losses of base cations from the soil into the streams due to fertilizer additions of nitrogen and sulfur (Fernandez et al., 2003). Lawrence et al. (1999) also performed an experiment that showed that calcium concentrations in leachate increased as acid concentrations increased.

The loss of base cations due to acidic deposition also is supported by other studies (Bailey et al., 2005). In an experiment using archived samples from 1967 and resampling in 1997, 1998, and 1999, Bailey et al. (2005) found that forest soils in the Allegheny National Forest had decreases in $\mathrm{pH}$ and exchangeable calcium and magnesium, and increases in exchangeable aluminum, though these trends were not observed over the 
three-year sampling period. They found that the majority of the change in calcium and magnesium could not be accounted for by forest growth, and they concluded that acid deposition was the driving force behind the cation leaching in the soil.

Another long term forest soils study shows similar results. Drohan and Sharpe (1997) resampled soils in Pennsylvania that had been initially sampled 14 to 36 years prior. They found that the upper soil horizons $(\mathrm{O}$ and $\mathrm{A})$ showed decreases in $\mathrm{pH}$, exchangeable calcium, and exchangeable magnesium with increased exchangeable aluminum in the A horizons. The main causes for the increased acidification and loss of base cations from these soils were forest uptake and acidic deposition (Drohan and Sharpe, 1997).

Base cations are replenished in forest soils to some degree by mineralization of litter fall, atmospheric deposition, and weathering (Jenkins, 2002; Johnson and Todd, 1990). Slope position also plays an important role in determining base cation levels. Lower slope positions accumulate more litter fall due to wind and gravity than higher slope positions (Johnson and Todd, 1990), therefore lower slope positions should have higher base cation concentrations.

\section{Ca:Al Molar Ratio}

The Ca:Al molar ratio is an indicator of the risk for forest decline due to aluminum antagonism and toxicity (Cronan and Grigal, 1995). Natural soil acidification, intensive tree harvesting, and acid deposition all deplete base cations, and thus, potentially increase soil-solution aluminum. Impaired uptake of already depleted calcium and magnesium supplies, growth reductions, and increased root mortality and turnover all are problems caused by high aluminum concentrations in soil (Cronan and Grigal, 1995). 
Soils with low Ca:Al molar ratios are more likely to have forest decline due to aluminum antagonism and toxicity. Cronan and Grigal (1995) estimated that a Ca:Al molar ratio of 1.0 results in a $50 \%$ risk of adverse impacts on forest; a Ca:Al molar ratio of 0.5 to 0.6 creates a 75\% risk of adverse impacts on forest; while a $\mathrm{Ca}$ :Al molar ratio of 0.2 gives a 95\% or greater risk of adverse impacts on forest. Jenkins (2002) found that soils in the Otter Creek watershed on the Monongahela National Forest in West Virginia commonly have a Ca:Al molar ratio of $<0.2$, along with a base saturation of the effective cation exchange capacity (BSECEC) of $<15 \%$. He interpreted these findings to mean that the associated forests are at 100\% risk for decline.

Lyon and Sharpe (1999) found that the Ca:Al molar ratios in forest soils of Pennsylvania had the highest risk in the B horizons. The B horizons were determined to be the upper rooting zone of most tree species in the study (Lyon and Sharpe, 1999). The $\mathrm{Ca}$ :Al molar ratios of the organic horizons were well above the threshold levels and not at risk. This was expected because both momomeric and polymeric aluminum are complexed with organic compounds and calcium is leached slowly from organic horizons (Lyon and Sharpe, 1999). After finding the Ca:Al molar ratios for several sites in Pennsylvania, Lyon and Sharpe (1999) compared them to the status of sugar maple (Acer saccharum Marsh.) "* in the areas the samples were taken. For declining stands, the median Ca:Al molar ratios were 13.2, 0.66, and 0.31 , respectively, for the $\mathrm{O}$ horizon, $\mathrm{A}$ horizon, and B horizon. For non-declining stands, the median Ca:Al molar ratios were 17.6, 1.93, 10.8, respectively, for the O horizon, A horizon, and B horizon. The A and B horizon values were significantly lower in the declining forests.

\footnotetext{
"Scientific names from Strausbaugh and Core, 1977.
} 


\section{Tree Response to Soil Acidification}

It is difficult to attribute tree decline and mortality to a single cause (Bailey et al., 2004). Sugar maple has declined significantly in the eastern U.S. in past years, and its response to changes in soil chemistry has been researched extensively. Sugar maple seems to be the species that is lost from stands first during soil acidification (Bailey et al., 2004). They found a correlation between foliar calcium and magnesium and soil exchangeable cations in New York and Pennsylvania. By using the base cation to aluminum ratio, the relationships between foliar and soil parameters were explained even further, suggesting that $\mathrm{Ca}$ :Al molar ratios are useful for predicting forest decline. Soil $\mathrm{pH}$ also was correlated with base cation concentrations in each horizon. Bailey et al. (2004) determined that the chemistry of the upper B horizon provided the best correlations for all factors.

Two other studies have focused on the effects of acidification on Appalachian forests using a variety of tree species. DeWalle et al. (1991) used tree rings to assess responses to soil chemistry changes. While elements translocate across the rings of some trees, sapwood had the greatest correlation with soil chemistry. Sapwood also was correlated most strongly to soil chemistry when $\mathrm{Ca}: \mathrm{Mn}, \mathrm{Mg}: \mathrm{Mn}$, and $\mathrm{Ca}: \mathrm{Al}$ ratios in soil were compared to tree ring chemistry (DeWalle et al., 1999). In that study, the Ca:Mn and $\mathrm{Mg}: \mathrm{Mn}$ ratios correlated most strongly to current soil chemistry. 


\section{Materials and Methods}

\section{Project Area Description}

The Cherry River watershed is located in Nicholas, Webster, and Greenbrier Counties of West Virginia. The watershed is predominantly forested and had timber harvests since the turn of the $20^{\text {th }}$ century (Reger, 1921). The rugged terrain of the watershed limits land use, though small family farms are scattered throughout the watershed in valleys and on ridge tops.

The predominant forest type is eastern deciduous hardwoods. The dominant tree types of the east project area are black cherry (Prinus serotina Ehrh.), sugar maple, red maple (Acer rubrum L.), American beech (Fagus grandifolia Ehrh.), and yellow poplar (Liriodendron tulipifera L.). There are large patches of hay-scented fern (Dennstaedtia punctilobula (Michx.) Moore) found in this area, which may be a possible indicator of soil acidification (Demchik and Sharpe, 1999). The west project area's dominant tree species are red oak (Quercus rubra L.), white oak (Quercus alba L.), and hickory (Carya spp. Nutt.).

The surface geologies of the study areas are comprised of the Kanawha and New River Formations of the Pottsville Group (Table 1.1). The Pottsville Group belongs to the Pennsylvanian period of the Paleozoic Era. The Kanawha Formation consists of $61.5 \%$ sandstone, $30.3 \%$ shale, $6.4 \%$ coal, and $1.8 \%$ impure and siliceous limestone (Reger, 1921). The New River Formation consists of 73.75\% sandstone, $22.5 \%$ shale, and $3.75 \%$ coal (Reger, 1921). The Kanawha Formation, which tends to be slightly more acid-forming than the New River Formation, is found only to a depth of $71 \mathrm{~m}$ (250 feet) in the east project area along ridge lines and on side slopes (Price, 1939). The upper most 
portion of this geology is the Lower Gilbert Sandstone which was identified near Hanging Rock (Price, 1939). Hanging Rock is located in the east project area at the highest point of the watershed. The Kanawha Formation is mapped as occurring on the ridges of the west project area; however, no members of this formation were recorded in measured sections (Reger, 1921) of the area or noted on field visits (Tracy, 2005). The New River Formation of the Pottsville covers the west project area with the Upper Nuttall Sandstone along the ridges (Reger, 1921). The formations of the Pottsville Group have a greater percentage of shale in the western part of the Gauley Ranger District (Tracy, 2005). The New River Formation consists of only $30 \%$ sandstone in the location of the west project area compared to $74 \%$ in other areas (Tracy, 2005). Surface water $\mathrm{pH}$ in the west project area was much higher $(\geq 6.0)$ than the surface waters from areas with higher sandstone content (4.0 - 5.0), like those found in the east project area (Tracy, 2005).

Table 1.1. General section of the Pottsville Group for the project areas of the Cherry River watershed (from Price, 1939). Rocks found in the Kanawha and New River Formations are given in order of depth from the surface for the watershed. Depth is in meters; feet given in parenthesis.

\begin{tabular}{llr}
\hline Kanawha Formation - 72 m (235 ft) & Thickness & \multicolumn{1}{l}{ Total } \\
\hline Sandstone, Lower Gilbert, massive, gray & $9-24(30-80)$ & $24(80)$ \\
\hline Shale, Gilbert, dark, laminated & $0-1.5(0-5)$ & $25(85)$ \\
\hline Shale, sandy & $0-6(0-20)$ & $31(105)$ \\
\hline Sandstone, Dotson, massive, gray & $6-20(20-65)$ & $51(170)$ \\
\hline Shale, sandy, dark & $1.5-5(5-15)$ & $56(185)$ \\
\hline Sandstone, Lower Dotson, massive, gray & $3-8(10-25)$ & $64(210)$ \\
\hline Shale, Douglas, dark, sandy, laminated & $1.5-5(5-15)$ & $69(225)$ \\
\hline Shale, gray and sandy & $0-3(0-10)$ & $72(235)$ \\
\hline New River Formation - 287 m (940 ft) & & \\
\hline $\begin{array}{l}\text { Sandstone, Upper Nuttall, massive to heavy and } \\
\text { current-bedded, grayish-white to brown }\end{array}$ & $15-21(50-70)$ & $91(300)$ \\
\hline Shale, dark, sandy & $0-6(0-20)$ & $98(320)$ \\
\hline $\begin{array}{l}\text { Coal, laeger "B", multiple-bedded, soft } \\
\text { Sandstone, Lower Nuttall, massive medium-grained, } \\
\text { gray to brown }\end{array}$ & $0-0.3(0-15-30$ & $98(320)$ \\
\hline
\end{tabular}


Coal, laeger "A", slaty

$0-0.3(0-1) \quad 128(420)$

Shale, Upper laeger, dark

$12-15(40-50) \quad 140(460)$

Coal, Hughes Ferry, single-bedded

$0.3-0.6(1-2) \quad 140(462)$

Shale, sandy

$0-1.5(0-5)$

$142(467)$

Sandstone, Middle laeger, grayish-white, medium-

grained

$3-14(10-45) \quad 156(512)$

Shale, sandy

$3-12(10-40)$

$159(522)$

Coal, Lower laeger, double-bedded

$0-0.6(0-2)$

$160(524)$

Fire clay shale

$0-0.3(0-1)$

$160(525)$

Sandstone, Lower laeger, gray and brown

$1.5-5(5-15)$

$165(540)$

Shale, Lower laeger, dark-gray

$5-11(15-35)$

$176(575)$

Sandstone, Harvey Conglomerate, medium-grained to coarse, grayish-white to brown, lenticular

Shale, Sandy Huff, dark-gray

$6-18(20-60)$

$181(595)$

Coal, Castle, single bedded, soft, columnar

$0-8(0-25)$

$189(620)$

Sandstone, Guyandot, massive, grayish-white, coarsegrained

$0-0.6(0-2)$

$189(620)$

Shale, Skelt, sandy and dark

$9-15(30-50)$

$204(670)$

Coal, Sewell "B", slaty, impure

$0-1.5(0-5)$

$205(675)$

Shale, sandy

$0-1(0-3)$

$206(678)$

Coal, Sewell "A", double-bedded, soft, columnar

$6-9(20-30)$

$216(708)$

Sandstone, Lower Guyandot, massive coarse-grained,

grayish-white

$0-0.6(0-2)$

$216(710)$

$3-9(10-30)$

$225(740)$

Shale, Hartridge, dark, with plant fossils carrying fresh

or brackish-water fossil shells

$0-1.5(0-5)$

$227(745)$

Coal Sewell, generally double-bedded, soft, columnar

$0.6-2(2-7)$

$229(752)$

Shale, gray, sandy, lenticular

$1.5-12(5-40)$

$231(757)$

Sandstone, Welch, massive to current-bedded, grayish-

white

6-14 (20-45) $244(802)$

Shale, dark, agrillaceous, lenticular

$0-1(0-3)$

$245(805)$

Coal, Welch, multiple-bedded, soft, columnar

$0-0.6(0-2)$

$246(807)$

Shale, gray, sandy

$0-1.5(0-5)$

$247(812)$

Sandstone, Upper Raleigh, heavy to current bedded,

grayish-white to brown

$15-23(50-75)$ $262(862)$

Coal, Little Raleigh "A", impure

$0-0.3(0-1)$ $263(863)$

Shale, sandy, lenticular

$0-8(0-25)$

$270(888)$

Coal, Little Raleigh, multiple-bedded, soft, columnar

$0.6-1(2-4)$

$271(890)$

Shale, sandy, lenticular

$1.5-5(5-15)$

$272(895)$

Sandstone, Lower Raleigh, massive to current-bedded, lenticular

$15-30(50-100)$

303 (995)

Coal, Beckley "Rider"

$0-0.6(0-2)$

304 (997) 
Shale, dark-gray, argillaceous, lenticular $0-6(0-20)$ $310(1017)$

Coal, Beckley, multiple-bedded, soft, columnar

$0-1(0-3)$ $311(1020)$

Sandstone, Quinnimont, lenticular $0-21(0-70)$ $332(1090)$

Shale, Quinnimont, dark-gray, siliceous to argilaceous, laminated, lenticular $1.5-12(5-40)$ $334(1095)$

Coal, Fire Creek, "Quinnimont", multiple-bedded, soft, columnar $0-2(0-7)$ $336(1102)$

Shale, sandy, with sandstone layers $3-8.5(10-28)$ $344(1130)$

Coal, Little Fire Creek, multiple-bedded, soft, columnar $0-0.6(0-2)$ $345(1132)$

Sandstone, Pineville, massive to current-bedded

$9-15(30-50)$
$360(1182)$ Shale, sandy $0-6(0-20)$ $360(1182)$

Coal, No. 9 Pocahontas, multiple bedded, soft, columnar $0-0.6(0-2)$ $360(1182)$ Shale and sandstone mixed $1-5(4-15)$ $362(1186)$ Coal, No. 8 Pocahontas, impure soft, columnar $0-1(0-4)$ $363(1190)$

The elevation of the Cherry River watershed varies from 570 to 1375 meters (1875 to 4510 feet) above sea level, with the east area at 790 to 1210 meters (2600 to 3925 feet) and the west area at 570 to 1000 meters (1875 to 3135 feet) (Figure 1.5). Frigid soils are present in the higher elevations of the watershed. Frigid soils are soils that have a mean annual soil temperature of less that $8^{\circ} \mathrm{C}$ (Brady and Weil, 2002). However, due to the different dates of soil mapping and the accepted protocol at the time of mapping among the counties, not all of the high elevation soils were mapped as frigid soils. Only the Greenbrier and Webster County Soil Surveys included frigid soils. The east project area was split between Nicholas (Soil Survey Staff, 1992), Webster (Soil Survey Staff, 1998), and Greenbrier County (Soil Survey Staff, 2002) soil surveys, while the west project area was located completely within the Nicholas County Soil Survey. 


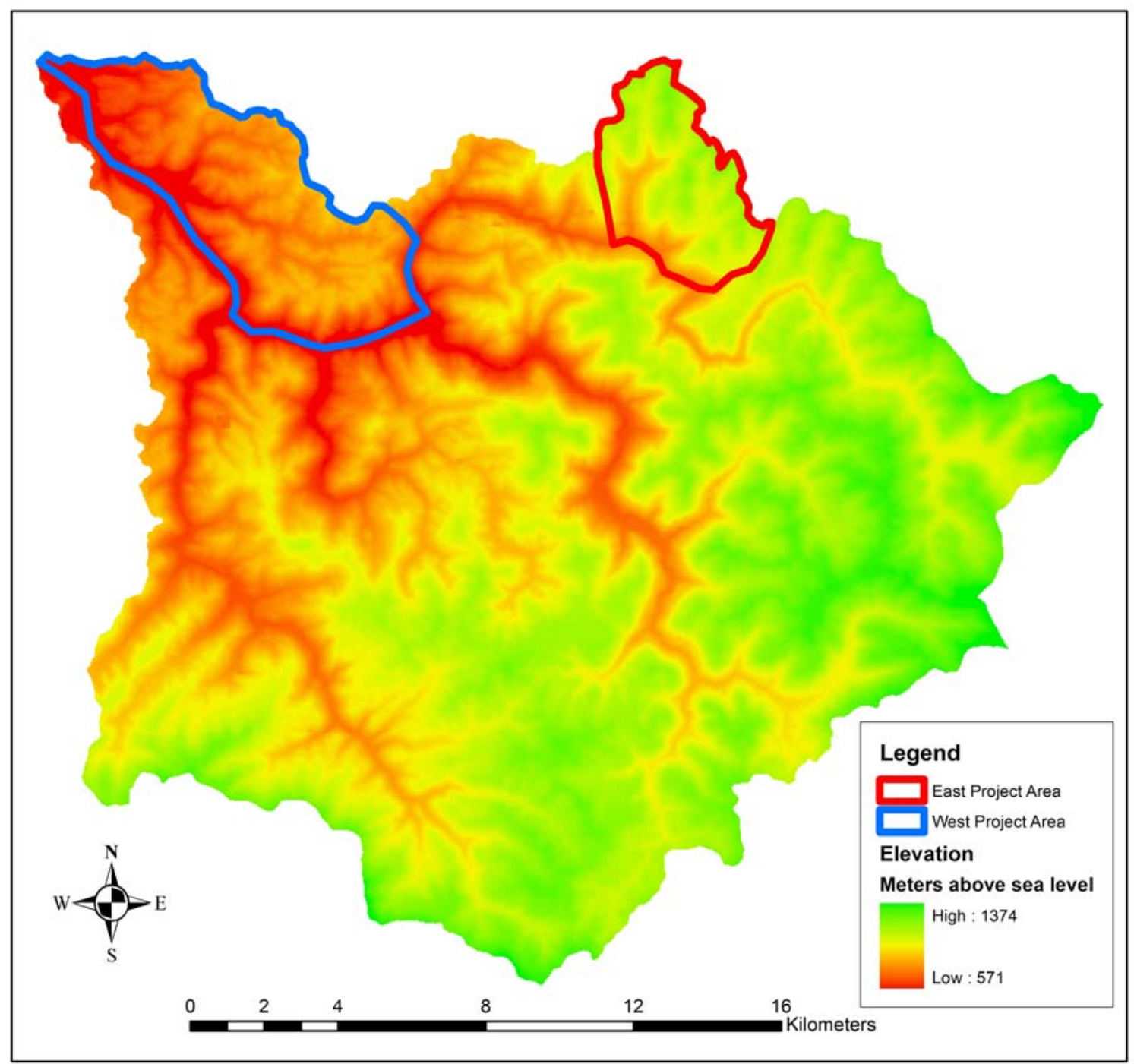

Figure 1.5. Elevation map for the Cherry River watershed.

In a study by Mount and Paetzold (2002), soil temperatures were determined for both project areas; the east area soils were determined to be frigid while the west area soils were found to be mesic. The major soils mapped in the east project area were Mandy (loamy-skeletal, mixed, active, frigid Typic Dystrudepts) and Snowdog (fineloamy, siliceous, active, frigid Typic Fragiudepts); the west project area was mapped predominately as Buchanan (fine-loamy, mixed, semiactive, mesic Aquic Fragiudults) and Gilpin (fine-loamy, mixed, active, mesic Typic Hapludults) (Table 1.2). 
Table 1.2. Soil mapping units for the project areas of the Cherry River watershed.

\begin{tabular}{|c|c|c|}
\hline $\begin{array}{l}\text { Project } \\
\text { Area }\end{array}$ & Dominant Soil Mapping Units & $\begin{array}{l}\text { Generic } \\
\text { Mapping Unit }\end{array}$ \\
\hline West & Buchanan Loam, 3 to 8 Percent Slopes & Buchanan \\
\hline West & $\begin{array}{l}\text { Buchanan Channery Fine Sandy Loam, } 15 \text { to } 35 \text { Percent Slopes, } \\
\text { Very Stony }\end{array}$ & Buchanan \\
\hline West & $\begin{array}{l}\text { Buchanan Channery Fine Sandy Loam, } 8 \text { to } 15 \text { Percent Slopes, } \\
\text { Very Stony }\end{array}$ & Buchanan \\
\hline West & Gilpin Channery Silt Loam, 15 to 25 Percent Slopes & Gilpin \\
\hline West & Gilpin Silt Loam, 15 to 25 Percent Slopes & Gilpin \\
\hline West & Gilpin Silt Loam, 15 to 35 Percent Slopes, Stony & Gilpin \\
\hline West & Gilpin Silt Loam, 25 to 35 Percent Slopes & Gilpin \\
\hline West & Gilpin Silt Loam, 3 to 15 Percent Slopes, Stony & Gilpin \\
\hline West & Gilpin Silt Loam, 3 to 8 Percent Slopes & Gilpin \\
\hline West & Gilpin Silt Loam, 35 to 70 Percent Slopes, Stony & Gilpin \\
\hline West & Gilpin Silt Loam, 8 to 15 Percent Slopes & Gilpin \\
\hline West & Gilpin-Buchanan Complex, 35 to 70 Percent Slopes, Very Stony & $\begin{array}{l}\text { Gilpin- } \\
\text { Buchanan }\end{array}$ \\
\hline East & $\begin{array}{l}\text { Mandy Channery Silt Loam, } 15 \text { to } 35 \text { Percent Slopes, Extremely } \\
\text { Stony }\end{array}$ & Mandy \\
\hline East & Mandy Channery Silt Loam, 15 to 35 Percent Slopes, Very Stony & Mandy \\
\hline East & $\begin{array}{l}\text { Mandy Channery Silt Loam, } 3 \text { to } 15 \text { Percent Slopes, Extremely } \\
\text { Stony }\end{array}$ & Mandy \\
\hline East & Mandy Channery Silt Loam, 3 to 15 Percent Slopes, Very Stony & Mandy \\
\hline East & $\begin{array}{l}\text { Mandy Channery Silt Loam, } 35 \text { to } 55 \text { Percent Slopes, Extremely } \\
\text { Stony }\end{array}$ & Mandy \\
\hline East & Mandy Channery Silt Loam, 35 to 55 Percent Slopes, Very Stony & Mandy \\
\hline East & Mandy Channery Silt Loam, 55 to 80 Percent Slopes, Very Stony & Mandy \\
\hline East & Snowdog Channery Loam, 15 to 35 Percent Slopes, Rubbly & Snowdog \\
\hline East & Snowdog Silt Loam, 15 to 35 Percent Slopes, Extremely Stony & Snowdog \\
\hline East & Snowdog Silt Loam, 3 to 15 Percent Slopes, Extremely Stony & Snowdog \\
\hline East & Snowdog Silt Loam, 35 to 55 Percent Slopes, Extremely Stony & Snowdog \\
\hline
\end{tabular}

The precipitation of the east and west areas of the watershed differs by an average of $13 \mathrm{~cm}$ (5 in). An EPA 30-yr average annual precipitation database shows that the east area receives 130 to $145 \mathrm{~cm}$ (51 to $57 \mathrm{in})$ per year with an average of $137 \mathrm{~cm}$ (54 in) and the west area receives 117 to $132 \mathrm{~cm}$ (46 to $52 \mathrm{in}$ ) per year with an average of $125 \mathrm{~cm}$ (49 in) (NADP, 2005). 
Using a wet sulfate deposition model based on National Oceanic and Atmospheric Administration (NOAA) precipitation data, topographic variables that affect precipitation, and NADP precipitation chemistry data created by Grimm and Lynch (2004), there were differences in sulfate deposition between the two project areas (Figure 1.6); the east area receives 26 to $31 \mathrm{~kg} \mathrm{ha}^{-1} \mathrm{yr}^{-1}$, and the west area receives 23 to $28 \mathrm{~kg} \mathrm{ha}^{-}$ ${ }^{1} \mathrm{yr}^{-1}$. As wet sulfate deposition has been estimated to account for half of total sulfate deposition (Driscoll et al, 2001), the east area receives approximately $60 \mathrm{~kg} \mathrm{ha}^{-1} \mathrm{yr}^{-1}$, and the west area receives approximately $50 \mathrm{~kg} \mathrm{ha}^{-1} \mathrm{yr}^{-1}$.

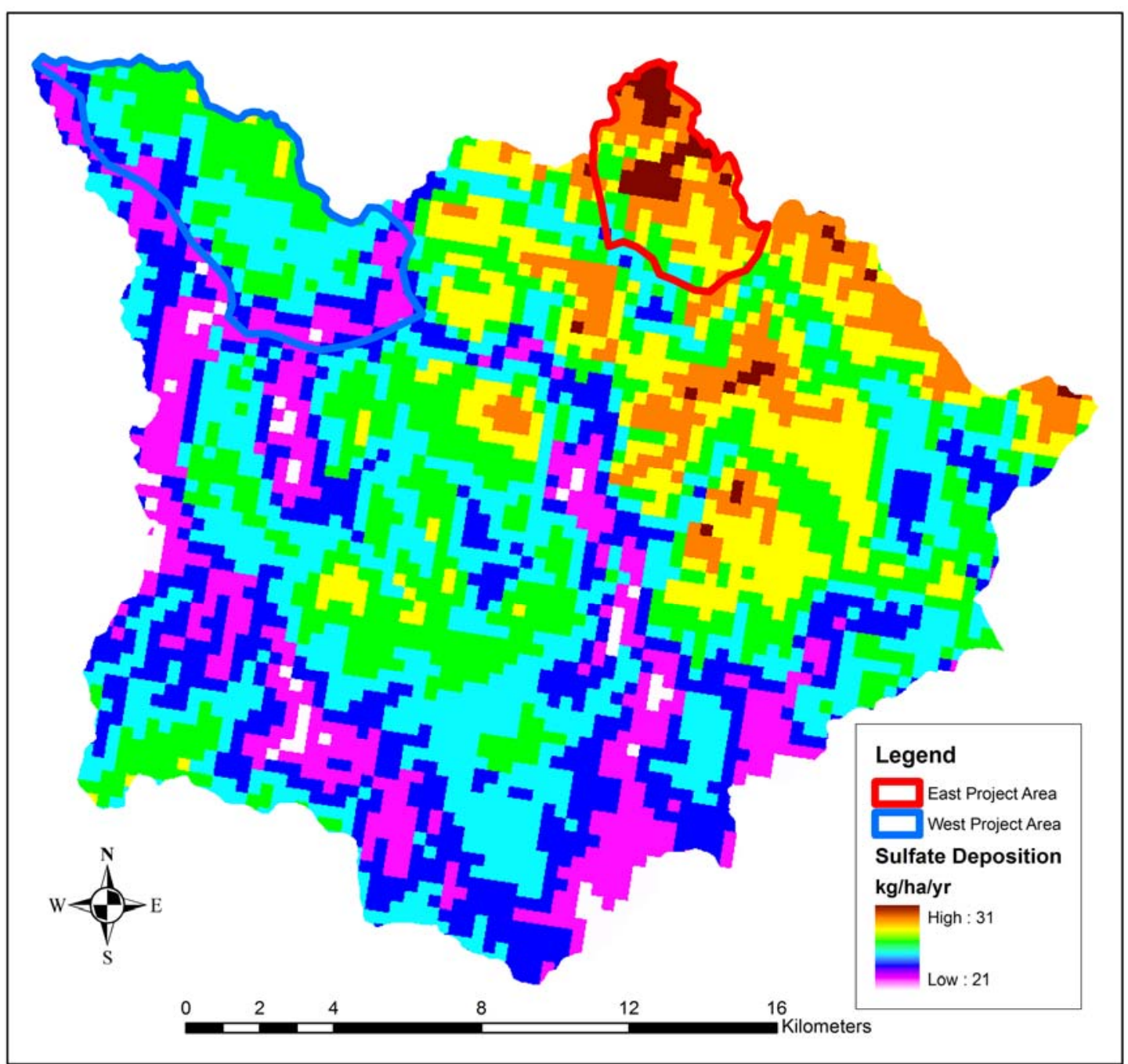

Figure 1.6. Wet sulfate deposition for the Cherry River watershed. 
While acidic deposition does not vary much across the watershed, stream water acidity increases east to west in the watershed (Table 1.3, Figure 1.7). A study conducted in the Neversink watershed in the Catskill Mountains of New York showed that the acid neutralizing capacity (ANC) of streams can be related to acidic deposition trends related to elevation (Lawrence et al., 1999). These differences presumably are due to the differences in elevation and soil and geologic differences across the watershed.

Table 1.4 gives a general overview of the east and west area differences discussed in this section.

Table 1.3. Water quality data from several streams in the Cherry River watershed. The streams are listed in order from east to west (see Figure 1.7). The data were generated from water samples taken in spring 2005.

\begin{tabular}{|c|c|c|c|c|c|c|c|}
\hline $\begin{array}{l}\text { Project } \\
\text { Area }\end{array}$ & Waterbody & $\mathbf{p H}$ & ANC* & $\mathbf{N a}$ & $\mathbf{K}$ & $\mathrm{NO}_{3}$ & $\mathrm{SO}_{4}$ \\
\hline & & & & & ueq $L$ & & \\
\hline \multirow[t]{5}{*}{ East } & Bear Run & 5.23 & -0.7 & 9.1 & 10.0 & 46.4 & 281.1 \\
\hline & Rabbit Run & 4.5 & -30.0 & 7.4 & 7.4 & 42.8 & 101.4 \\
\hline & Hunters Run & 5.06 & -14.2 & 7.0 & 6.9 & 27.1 & 82.5 \\
\hline & Desert Branch & 5.35 & -1.1 & 8.7 & 7.4 & 25.7 & 89.1 \\
\hline & Windy Run & 4.5 & -34.9 & 7.0 & 6.9 & 29.3 & 97.6 \\
\hline \multirow[t]{5}{*}{ West } & Morris Creek & 6.14 & 12.8 & 20.0 & 11.8 & 27.1 & 92.2 \\
\hline & Holcomb Run & 5.58 & -0.1 & 12.6 & 10.2 & 25.7 & 93.7 \\
\hline & Buckheart Run & 5.48 & -7.5 & 23.9 & 11.8 & 23.6 & 87.0 \\
\hline & Coal Siding Run & 6.08 & 24.5 & 15.2 & 12.3 & 30.7 & 121.0 \\
\hline & Curtain Run & 5.47 & -9.5 & 10.9 & 10.2 & 18.6 & 98.3 \\
\hline
\end{tabular}




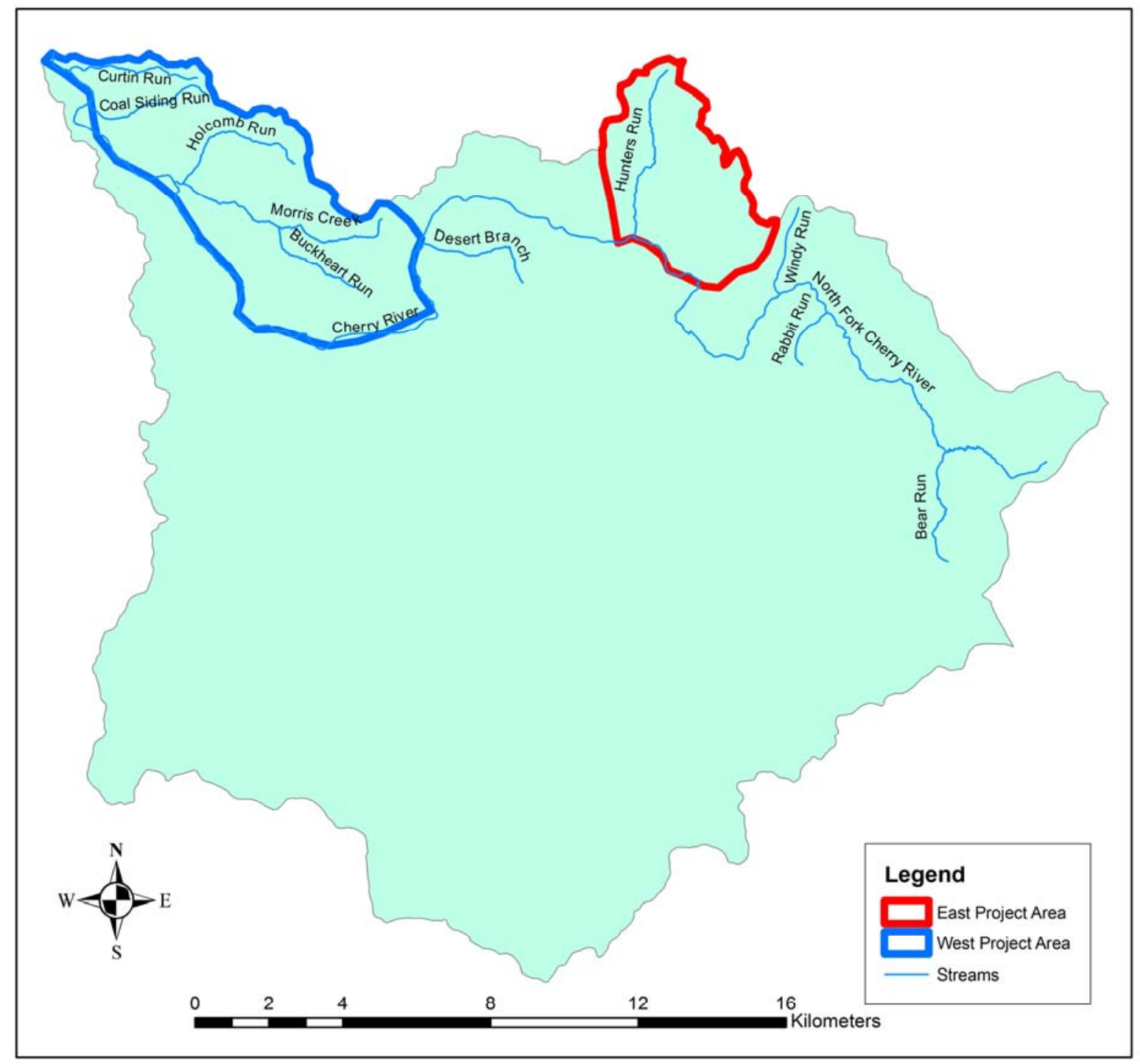

Figure 1.7. Location of streams sampled in the Cherry River watershed. 
Table 1.4. A comparison of soils, tree types, geology, and precipitation information between the east and west project areas.

\begin{tabular}{|c|c|c|}
\hline Project Area & East Area & West Area \\
\hline $\begin{array}{l}\text { Dominant Soil Mapping } \\
\text { Units }\end{array}$ & Mandy, Snowdog & Gilpin, Buchanan \\
\hline Dominant Tree Species & $\begin{array}{l}\text { Black cherry, Maple, American } \\
\text { beech, Yellow poplar }\end{array}$ & Oak, Hickory \\
\hline Bedrock Types & Gray sandstone, black shale & Red sandstone, gray shale \\
\hline Elevation & $790-1210 \mathrm{~m}(2600-3925 \mathrm{ft})$ & $570-1000 \mathrm{~m}(1875-3135 \mathrm{ft})$ \\
\hline Geology Group & Pottsville & Pottsville \\
\hline Geology Formation & Kanawha & New River \\
\hline Forest Type & Eastern deciduous hardwood & Eastern deciduous hardwood \\
\hline Precipitation & $\begin{array}{l}130-145 \mathrm{~cm}(51-57 \mathrm{in}) ; \\
\text { Avg. } 137 \mathrm{~cm}(54 \mathrm{in})\end{array}$ & $\begin{array}{l}117-132 \mathrm{~cm}(46-52 \mathrm{in}) ; \\
\text { Avg. } 125 \mathrm{~cm}(49 \mathrm{in})\end{array}$ \\
\hline Modeled wet sulfate & $26-31 \mathrm{~kg} \mathrm{ha}^{-1} \mathrm{yr}^{-1}$ & $23-28 \mathrm{~kg} \mathrm{ha}^{-1} \mathrm{yr}^{-1}$ \\
\hline
\end{tabular}

\section{Field and Laboratory Methods}

Two types of soil pits were dug in the summer of 2004 in the east and west project areas of the Cherry River watershed: full characterization pits and satellite pits. Sixteen full characterization pits were excavated to $150 \mathrm{~cm}$ (60 in) or bedrock and a complete soil description was recorded (description guidelines provided in Appendix A, descriptions provided in Appendix B). Fifty-one satellite pits were excavated through the top three horizons of the soil (A, BA or $\mathrm{AB}$ or $\mathrm{A} 2$, and $\mathrm{B})$, which extended to a depth of 30.5 to $50 \mathrm{~cm}$ (12 to $20 \mathrm{in}$ ), and brief descriptions, including soil color, texture, and structure, were noted (descriptions provided in Appendix C). 
There were five criteria used for selecting sites. First, the site had to be on U.S. Forest Service property. Second, the site needed to be relatively accessible by a Forest Service road. Third, the site needed to be representative of the landscape position on which it was found. Fourth, the site could not to be located below a road culvert or other type of cross drain. And finally, the site needed to show no signs of recent disturbance.

Six landscape positions were identified for use in this project: ridge top, shoulder, back slope, bench, foot slope, and floodplain (Figure 1.8). Full characterization pits were excavated in each of these landscape positions in both project areas. In the east project area, nine full characterization pits were located: one on the ridge top, two on shoulders, two on back slopes, one on a bench, two on foot slopes, and one in a floodplain. The west project area had seven sites: two ridge top, one shoulder, one back slope, one bench, one foot slope, and one floodplain. Satellite pits also were located on each of these landscape positions in both project areas: 27 in the east project area and 23 in the west project area. (Table 1.5).

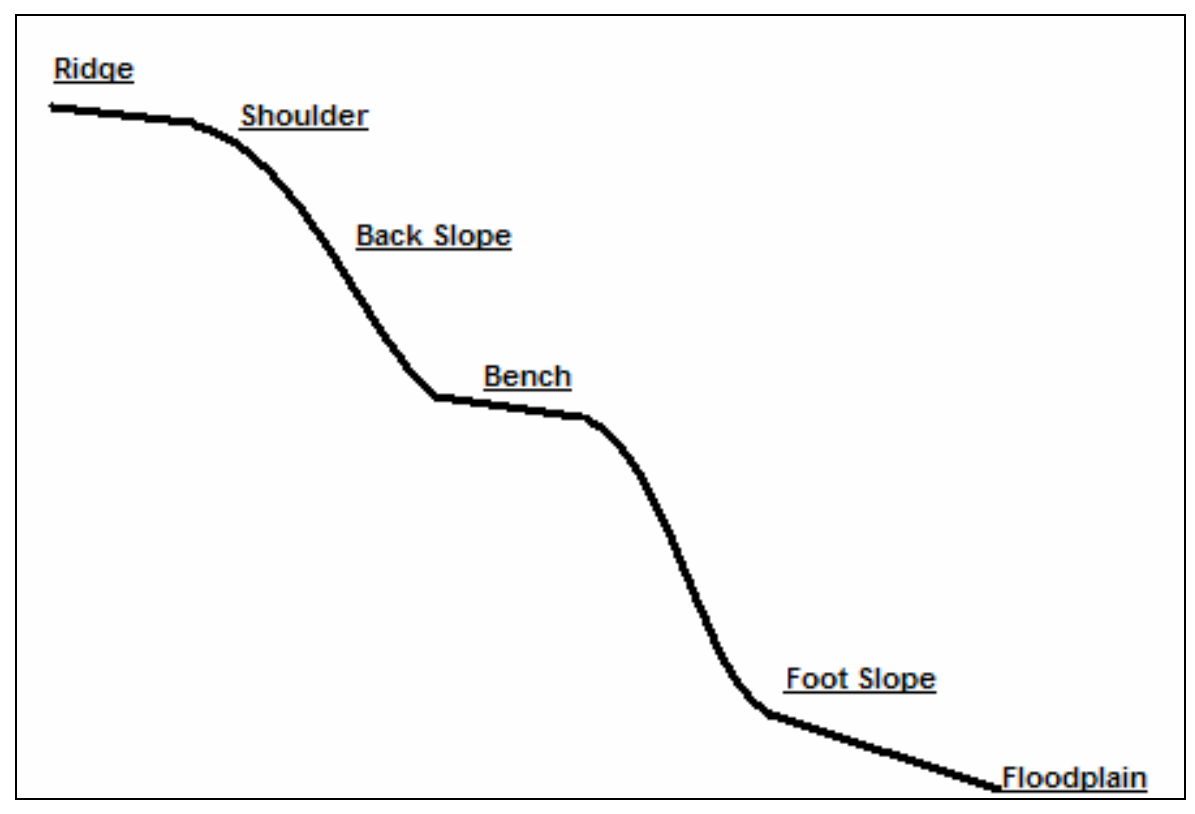

Figure 1.8. Landscape positions on which soils were sampled. 
After field evaluation the parent material of all soil pits was identified as residuum, colluvium, or alluvium. Residuum is the parent material of a soil that has formed in place. Colluvium is the parent material of a soil that has moved down slope due to gravity. Alluvium is the parent material of a soil that has formed from deposits from moving water. Ridge top pits, some of the back slope pits, and some of the bench pits were residuum. The remaining back slope and bench pits were colluvium along with the foot slope pits. Floodplain pits were classified as alluvium.

Table 1.5. Number of soil pits in each landscape position by project area

\begin{tabular}{lcccc}
\hline Landscape Position & \multicolumn{2}{c}{ East project area pits } & \multicolumn{2}{c}{ West project area pits } \\
\hline Ridge & Full & Satellite & Full & Satellite \\
Shoulder & 2 & 4 & 2 & 6 \\
Back Slope & 2 & 3 & 1 & 4 \\
Bench & 2 & 7 & 1 & 5 \\
Foot Slope & 1 & 6 & 1 & 4 \\
Floodplain & 1 & 4 & 1 & 3 \\
\hline & 1 & 3 & 1 & 2 \\
Total & 9 & 27 & 7 & 24 \\
\hline
\end{tabular}

Soil pits were identified using a 5-part code. "FS" was used to specify that all samples were collected from Forest Service lands. A two digit number was used to designate the year of collection (i.e., "04" for 2004). "WV" was used to show the sample was collected in West Virginia. The fourth part of the code was the three digit NRCS County SURGO code (http://www.ncgc.nrcs.usda.gov/products/datasets/ssurgo /index.html), and the fifth part of the code (three digit) was used to identify the sample number within the county. For example, the first pit in Nicholas County was labeled FS04WV067001.

The coordinates for each pit were recorded in Universal Transverse Mercator (UTM) North American Datum of 1983 (NAD83) Zone North 17 using a Magellan 
SporTrak GPS unit (Forestry Suppliers Inc., Jackson, MS). GPS readings were taken

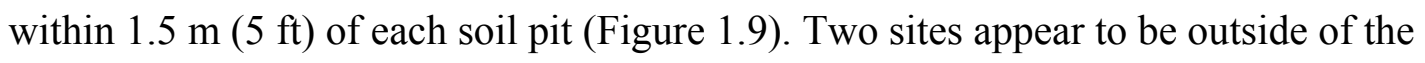
watershed. The site near the east area was on the ridgeline forming the border of the watershed and therefore in the project area. The site near the west area was located in the Cranberry River watershed. However, due to the similarity of the location to the west project area, the data was used.

In summer 2004, soils from the pits were sampled by horizon starting with the bottom of the soil profile. A soil knife was used to chip or excavate the soil into a dust pan. The sample was taken from multiple areas across the soil pit face until an estimated mass $>2 \mathrm{~kg}$ was obtained. This large sample then was divided into four subsamples, three of which were sent for analysis to West Virginia University, The Pennsylvania State University Agricultural Analytical Services Laboratory, and the University of Maine Analytical Laboratory. The fourth subsample was retained as an archive sample.

In summer 2005, bulk density samples of surface horizons were collected by the frame excavation method at all 16 full characterization pits (Grossman et al. 2001). Bulk density by the clod method (Soil Survey Staff, 1996) was measured on subsurface horizons with three clods taken per horizon.

At The Pennsylvania State University Agricultural Analytical Services Laboratory, aluminum and calcium were determined by $0.1 \mathrm{M} \mathrm{SrCl}_{2}$ extraction (Joslin and Wolfe, 1989). The Ca:Al molar ratio used to assess risk for forest productivity decline was calculated from this extraction. The University of Maine Analytical Laboratory determined soil $\mathrm{pH}$ measured in distilled water, organic matter by loss on ignition (LOI), percent total carbon (TC) and percent total nitrogen (TN) by dry 
combustion. Maine also determined extractable calcium, potassium, magnesium, aluminum, iron, manganese, and sodium by ammonium acetate extraction, exchangeable acidity by potassium chloride extraction, and effective cation exchange capacity (ECEC) by summation of calcium, potassium, magnesium, sodium by ammonium acetate, and exchangeable acidity by potassium chloride in meq $100 \mathrm{~g}^{-1}$. At West Virginia University, soil texture by pipette method (method 3A1a), bulk density by the frame excavation method (method 3B5), and bulk density by the saran-coated clod method (method 3B1) were determined (Soil Survey Staff, 1996).

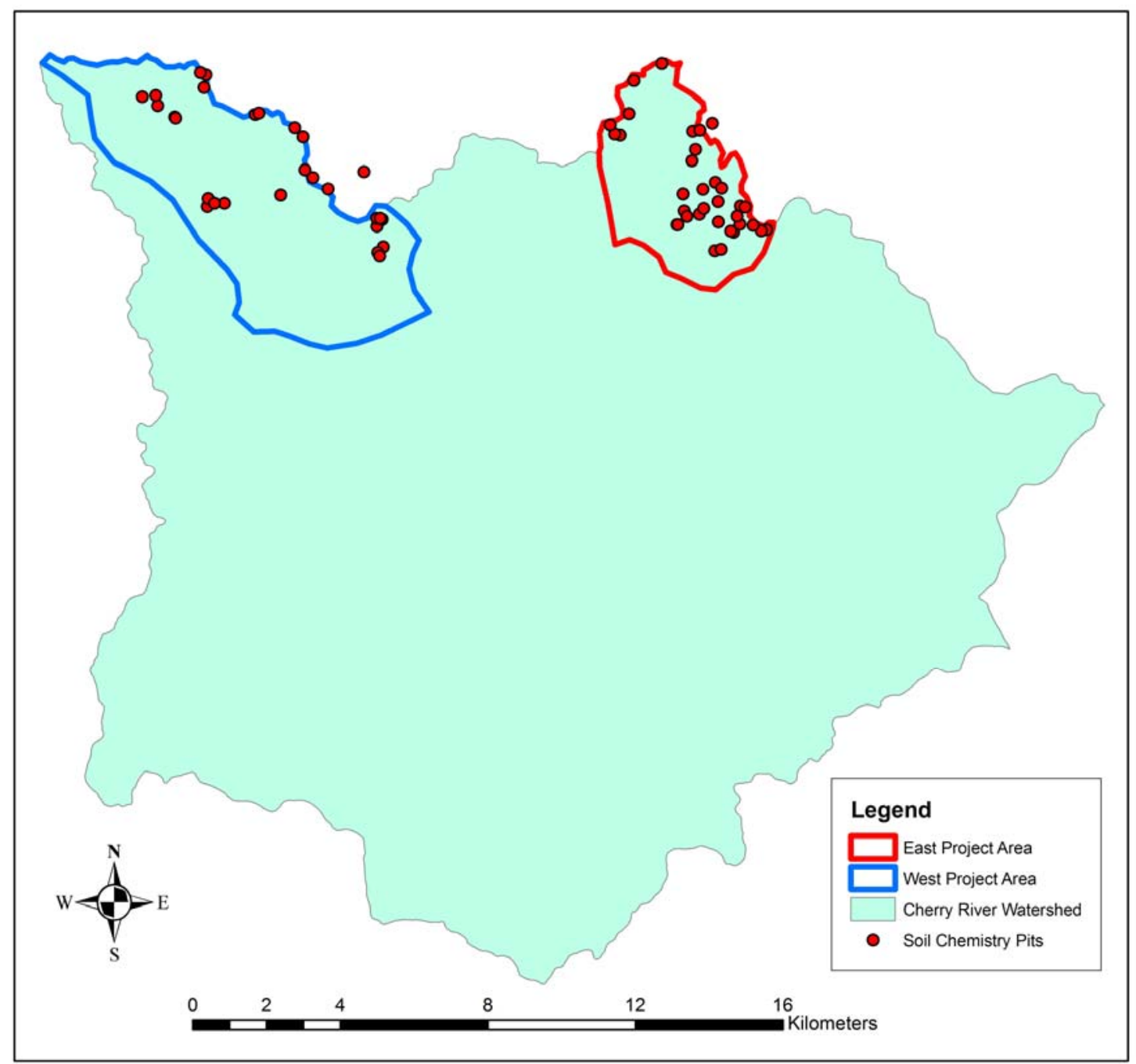

Figure 1.9. Soil pit locations on the Cherry River watershed in West Virginia. 
Base saturation of the effective cation exchange capacity (BSECEC) was calculated by summation of base cations (ammonium acetate) divided by the ECEC. Base saturation values were used in conjunction with the $\mathrm{Ca}$ :Al molar ratios to assess risk to forest productivity. Risk was determined using the criteria set by Cronan and Grigal (1995): a 50\% risk exists for aluminum toxicity if the $\mathrm{Ca}$ :Al molar ratio is $\leq 1.0$; a $75 \%$ risk exists if the $\mathrm{Ca}: \mathrm{Al}$ molar ratio is $\leq 0.5$; a $95 \%$ risk exists when the $\mathrm{Ca}$ :Al molar ratio is $\leq 0.2$. If the $\mathrm{BSECEC}$ is $\leq 15 \%$ when the $\mathrm{Ca}$ : $\mathrm{Al}$ molar ratio is $\leq 0.2$, there is a $100 \%$ risk of aluminum toxicity.

For classification of the soils, the BSECEC was assumed to represent the base saturation of the cation exchange capacity (CEC). In standard soil survey classification, two methods are used to determine CEC: the first being, ammonium acetate extraction at $\mathrm{pH} 7$, and the second, summation of base cations extracted by ammonium acetate and acidity extracted by barium chloride-triethanolamine (Soil Survey Staff, 2003). The base cation extraction used by Soil Survey is the same as in this study. Both Soil Survey standard methods overestimate the CEC of acid soils (Skinner et al., 2001; Thomas, 1982). The ECEC used in this study provided an estimate of CEC at field $\mathrm{pH}$ that is lower than the standard methods. Therefore, the BSECEC as determined in the present study should give a higher percent base saturation than using the CEC methods (Skinner et al., 2001; Thomas, 1982). All BSECEC found for these soils were less than 35\% or $60 \%$, and therefore the methods used in the present study are predicted to give similar results as standard methods for the classification of the soils.

Analysis of variance (ANOVA) was used to make several comparisons. The SAS GLM procedure was used to compare the east and west values of the A, transition, and 
uppermost B horizons. The sample size of the lower horizons was too small to analyze statistically. No comparisons were made between $\mathrm{C}$ horizons of the project areas because there were no $\mathrm{C}$ horizons sampled in the east area. The SAS GLM procedure also was used to compare the A horizon to the upper B horizon. The data were not analyzed statistically among landscape positions due to the small sample sizes when the positions were split between project areas; however, trends were identified visually. Regression slopes of related parameters were tested against $\mathrm{pH}$ to determine if they were significantly different from zero. 


\section{Chapter 2. \\ Physical Soil Properties}

\section{Results and Discussion}

\section{Physical Properties}

The physical properties analyzed for this study were texture and bulk density. Bulk densities were determined for only the full characterization pits.

\section{East versus West}

The mean soil physical properties are shown by horizon in Table 2.1 for the east and west project area comparison. Both sand and clay percentages were significantly different between project areas for all of the soil horizons, except the BC horizons. The silt percentages were significantly different between areas only in the B horizons. In the $\mathrm{BC}$ horizons, the mean percentages for sand, silt, and clay were not statistically different between project areas.

Clay content was higher in east area soils, while sand was higher in west area soils. Therefore, it is assumed that the soils of the east area were formed from parent material such as shale or mudstone, and the west area soils were formed from coarser parent material like sandstone.

Mean clod bulk densities for the project areas were statistically different (Table 2.1). The east area soils were less dense in the subsurface horizons than those of the west areas. Soils in the east also had higher organic matter content throughout the horizons (Chapter 3), contributing to the lower bulk densities. Frigid soils in Virginia were found to have lower bulk densities than mesic soils (Miller et al., 2004). However, frame bulk density values were not statistically different between areas. 
Table 2.1. Mean texture and bulk density data for the soils by horizon for east and west areas.

\begin{tabular}{llccccc}
\hline Project Area & Horizon & $\begin{array}{c}\text { Sand } \\
\mathbf{\%}\end{array}$ & $\begin{array}{c}\text { Silt } \\
\mathbf{\%}\end{array}$ & $\begin{array}{c}\text { Clay } \\
\mathbf{\%}\end{array}$ & \multicolumn{2}{c}{$\begin{array}{c}\text { Bulk Density } \\
\mathbf{g} \mathbf{~ c m}^{-3}\end{array}$} \\
\hline & & & & & Clod & Frame \\
\hline Range & & & & & $0.78-$ & $0.26-$ \\
\hline East & A & $7-84$ & $12-72$ & $1-44$ & 1.82 & 1.23 \\
West & A & $42^{*}$ & 47 & $23^{*}$ & -- & 0.69 \\
\hline East & Transition & $33^{*}$ & 42 & $15^{*}$ & -- & 0.61 \\
West & Transition & $42^{*}$ & 40 & $18^{*}$ & $1.07^{*}$ & 0.85 \\
\hline East & Upper B & $27^{*}$ & $45^{*}$ & $28^{*}$ & $1.22^{*}$ & 0.77 \\
West & Upper B & $42^{*}$ & $41^{*}$ & $17^{*}$ & $1.38^{*}$ & -- \\
\hline East & Lower B & $26^{*}$ & $53^{*}$ & $21^{*}$ & $1.45^{*}$ & -- \\
West & Lower B & $41^{*}$ & $42^{*}$ & $17^{*}$ & $1.52^{*}$ & -- \\
\hline East & BC & 38 & 42 & 19 & $1.33^{*}$ & -- \\
West & BC & 38 & 47 & 15 & $1.58^{*}$ & -- \\
\hline East & C & -- & -- & -- & -- & -- \\
West & C & 69 & 22 & 9 & 1.72 & -- \\
\hline
\end{tabular}

* shows significant difference between east and west at $\alpha=0.05$.

Bulk densities increased with depth in the soil for both project areas. This is a common trend in natural soils (Brady and Weil, 2002; Logsdon and Cambardella, 2000) because the gravitational pressure of the upper horizons compacts the lower soil horizons, thereby increasing the bulk density. Soils studied in Otter Creek, West Virginia, showed the same trend (Schnably, 2003).

\section{Landscape Positions \\ East Area}

The texture and bulk density data of the east landscape positions are shown in Table 2.2. There were no apparent differences between landscape positions for the physical properties of the east area. The floodplain soil was not sampled for bulk density in the east area due to high water in the soil pit that could not be pumped out. 
Table 2.2. Texture and bulk density data for east area landscape positions.

\begin{tabular}{|c|c|c|c|c|c|c|}
\hline \multirow[t]{2}{*}{$\begin{array}{l}\text { Landscape } \\
\text { Position }\end{array}$} & \multirow[t]{2}{*}{ Horizon } & \multirow[t]{2}{*}{$\begin{array}{c}\text { Sand } \\
\%\end{array}$} & \multirow[t]{2}{*}{$\begin{array}{c}\text { Silt } \\
\%\end{array}$} & \multirow[t]{2}{*}{$\begin{array}{c}\text { Clay } \\
\% \\
\end{array}$} & \multicolumn{2}{|c|}{$\begin{array}{c}\text { Bulk Density } \\
\mathrm{g} \mathrm{cm}^{-3} \\
\end{array}$} \\
\hline & & & & & Clod & Frame \\
\hline Range & & $7-84$ & $12-72$ & $1-44$ & $\begin{array}{c}0.78- \\
1.82\end{array}$ & $\begin{array}{c}0.26- \\
1.23\end{array}$ \\
\hline Ridge & $\mathrm{A}$ & 25 & 55 & 20 & -- & 0.83 \\
\hline Shoulder & A & 21 & 53 & 26 & -- & 0.65 \\
\hline Back slope & A & 33 & 44 & 22 & -- & 0.47 \\
\hline Bench & A & 37 & 43 & 20 & -- & 0.36 \\
\hline Foot slope & A & 31 & 48 & 21 & -- & 1.23 \\
\hline Floodplain & A & 34 & 33 & 33 & -- & -- \\
\hline Ridge & Transition & 30 & 44 & 26 & 1.17 & -- \\
\hline Shoulder & Transition & 21 & 54 & 26 & 1.18 & -- \\
\hline Back slope & Transition & 29 & 42 & 29 & 1.01 & -- \\
\hline Bench & Transition & 46 & 32 & 22 & 0.78 & -- \\
\hline Foot slope & Transition & 29 & 47 & 24 & 1.09 & -- \\
\hline Floodplain & Transition & 42 & 33 & 24 & -- & -- \\
\hline Ridge & Upper B & 22 & 48 & 30 & 1.38 & -- \\
\hline Shoulder & Upper B & 21 & 48 & 31 & 1.27 & -- \\
\hline Back slope & Upper B & 27 & 44 & 29 & 1.13 & -- \\
\hline Bench & Upper B & 34 & 41 & 25 & 1.03 & -- \\
\hline Foot slope & Upper B & 24 & 49 & 27 & 1.21 & -- \\
\hline Floodplain & Upper B & 36 & 36 & 28 & -- & -- \\
\hline Ridge & Lower Horizons & 12 & 66 & 21 & 1.39 & -- \\
\hline Shoulder & Lower Horizons & 26 & 55 & 19 & 1.41 & -- \\
\hline Back slope & Lower Horizons & 45 & 36 & 19 & 1.19 & -- \\
\hline Bench & Lower Horizons & 24 & 48 & 28 & 1.59 & -- \\
\hline Foot slope & Lower Horizons & 38 & 46 & 16 & 1.58 & -- \\
\hline Floodplain & Lower Horizons & 44 & 41 & 15 & -- & -- \\
\hline
\end{tabular}

\section{West Area}

The data for the physical properties for the west area landscape positions are shown in Table 2.3. The floodplain soils appeared to have less silt in the upper three horizons than the other landscape positions. There were no apparent trends in other physical properties. 
Table 2.3. Texture and bulk density data for west area landscape positions.

\begin{tabular}{|c|c|c|c|c|c|c|}
\hline \multirow[t]{2}{*}{$\begin{array}{l}\text { Landscape } \\
\text { Position }\end{array}$} & \multirow{2}{*}{ Horizon } & \multirow[t]{2}{*}{$\begin{array}{c}\text { Sand } \\
\%\end{array}$} & \multirow[t]{2}{*}{$\begin{array}{c}\text { Silt } \\
\%\end{array}$} & \multirow[t]{2}{*}{$\begin{array}{c}\text { Clay } \\
\%\end{array}$} & \multicolumn{2}{|c|}{$\begin{array}{c}\text { Bulk Density } \\
\mathrm{g} \mathrm{cm}^{-3}\end{array}$} \\
\hline & & & & & Clod & Frame \\
\hline Range & & $7-84$ & $12-72$ & $1-44$ & $\begin{array}{c}0.78- \\
1.82 \\
\end{array}$ & $\begin{array}{c}0.26- \\
1.23 \\
\end{array}$ \\
\hline Ridge & A & 39 & 47 & 14 & -- & 0.68 \\
\hline Shoulder & A & 55 & 31 & 14 & -- & 0.56 \\
\hline Back slope & A & 39 & 44 & 17 & -- & 0.49 \\
\hline Bench & A & 33 & 50 & 17 & -- & 0.56 \\
\hline Foot slope & A & 36 & 44 & 20 & -- & 0.58 \\
\hline Floodplain & A & 56 & 34 & 9 & -- & 0.70 \\
\hline Ridge & Transition & 43 & 39 & 18 & 1.19 & -- \\
\hline Shoulder & Transition & 54 & 33 & 13 & 1.21 & -- \\
\hline Back slope & Transition & 37 & 44 & 19 & 1.52 & -- \\
\hline Bench & Transition & 34 & 45 & 21 & 1.30 & -- \\
\hline Foot slope & Transition & 32 & 47 & 22 & 1.00 & -- \\
\hline Floodplain & Transition & 63 & 25 & 12 & 1.28 & -- \\
\hline Ridge & Upper B & 41 & 41 & 18 & 1.45 & -- \\
\hline Shoulder & Upper B & 51 & 35 & 14 & 1.25 & -- \\
\hline Back slope & Upper B & 38 & 44 & 19 & 1.55 & -- \\
\hline Bench & Upper B & 28 & 52 & 20 & 1.44 & -- \\
\hline Foot slope & Upper B & 36 & 44 & 20 & 1.27 & -- \\
\hline Floodplain & Upper B & 61 & 29 & 10 & 1.22 & -- \\
\hline Ridge & Lower Horizons & 51 & 37 & 12 & 1.65 & -- \\
\hline Shoulder & Lower Horizons & 35 & 51 & 13 & 1.53 & -- \\
\hline Back slope & Lower Horizons & 62 & 26 & 12 & 1.56 & -- \\
\hline Bench & Lower Horizons & 32 & 52 & 15 & 1.65 & -- \\
\hline Foot slope & Lower Horizons & 25 & 54 & 21 & 1.44 & -- \\
\hline Floodplain & Lower Horizons & 60 & 26 & 14 & 1.43 & -- \\
\hline
\end{tabular}

\section{Conclusions}

The physical properties of the soils showed few differences between project areas and no apparent trends among landscape positions. The west area had coarser textured soils than the east area. The bulk density of the east area subsoils was less than that of the west area, which was attributed to organic matter incorporation (Chapter 3). 


\section{Chapter 3. \\ General Soil Chemistry}

\section{Results and Discussion}

\section{$\underline{\text { East area versus West area }}$}

General soil chemistry variables are divided into sets for examination: these include soil acidity, base cations, acid cations, and carbon and nitrogen. Each set of variables was compared between watershed areas in the $\mathrm{A}$, transition $(\mathrm{AB}, \mathrm{BA}, \mathrm{BE}$, or $\mathrm{AE})$, and upper B horizons. Due to the small number of samples in the lower horizons, they were not analyzed statistically.

\section{Soil Acidity}

The parameters included in the soil acidity set are $\mathrm{pH}$, acidity, effective cation exchange capacity (ECEC), and base saturation of the effective cation exchange capacity (BSECEC). Mean acidity and ECEC were significantly higher in the east than in the west for the A, transition, and upper B horizons (Table 3.1), and mean $\mathrm{pH}$ was significantly lower in the east for the same horizons. The BSECEC of the transition and upper B horizons was significantly higher in the west than in the east. The BSECEC also was higher in the west in the lower $\mathrm{B}$ and $\mathrm{BC}$ horizons. These differences are explainable by geology with higher base status in the west area.

Soil $\mathrm{pH}$ increased with depth, and acidity and ECEC decreased with depth. BSECEC showed no consistent trend (Table 3.1). For all of the variables, the A horizon and upper B horizon were significantly different between areas. 
Table 3.1. Acidity by horizon compared between watershed areas.

\begin{tabular}{lccccc}
\hline Area & Horizon & Soil pH & Acidity & ECEC & BSECEC \\
\cline { 3 - 6 } & & & $\mathbf{m e q ~ 1 0 0 g}^{-1}$ & $\mathbf{M e q ~ 1 0 0 g}^{-1}$ & $\%$ \\
\hline Range & A & $3.1-5.1$ & $0.4-16.4$ & $1.1-27.3$ & $2.1-75.0$ \\
West & A & $4.0+* *$ & $9.4+* *$ & $10.7+* *$ & $12.9+$ \\
East & Transition & $4.1^{* *}$ & $8.5^{* *}$ & $7.2+* *$ & $15.1+$ \\
West & Transition & $4.3^{* *}$ & $4.3^{* *}$ & $9.0^{* *}$ & $5.9^{*}$ \\
\hline East & Upper B & $4.3+*$ & $6.9+* *$ & $7.3+* *$ & $7.9^{*}$ \\
West & Upper B & $4.5+*$ & $3.7+* *$ & $4.0+* *$ & $7.0+* *$ \\
\hline East & Lower B & 4.6 & 4.7 & 5.0 & 5.5 \\
West & Lower B & 4.5 & 4.2 & 4.5 & 7.2 \\
\hline East & BC & 4.6 & 4.2 & 4.5 & 7.3 \\
West & BC & 4.5 & 3.3 & 3.6 & 9.9 \\
\hline East & C & -- & -- & -- & - \\
West & C & 4.7 & 1.6 & 2.1 & 28.6 \\
\hline
\end{tabular}

* shows significant difference between project areas at $\alpha=0.05$.

$* *$ shows significant difference between project areas at $\alpha=0.0001$.

+ shows significant difference between $A$ and Upper B horizon at $\alpha=0.05$.

The effective cation exchange capacity (ECEC) was partially explained by soil $\mathrm{pH}$ (Figure 3.1). As pH increased, ECEC decreased. However, the normal trend for soils is an increase in ECEC as $\mathrm{pH}$ increases (Brady and Weil, 2002). The low range of $\mathrm{pH}$ values maintained an aluminum-controlled ECEC rather than base-cation controlled ECEC which occurs at a pH of $\geq 5.5$ (Brady and Weil, 2002). With these soils, higher ECEC values were found in the east area where soil $\mathrm{pH}$ values are lower. C.E. Johnson (2002) also found this negative relationship in soils in the northeastern United States. The trend was explained by $\mathrm{pH}$ and organic matter relationships. It was seen that the carboxyl groups in humus provided $\mathrm{H}^{+}$increasing the ECEC and buffering capacity retaining the higher $\mathrm{pH}$ (Johnson, 2002). 


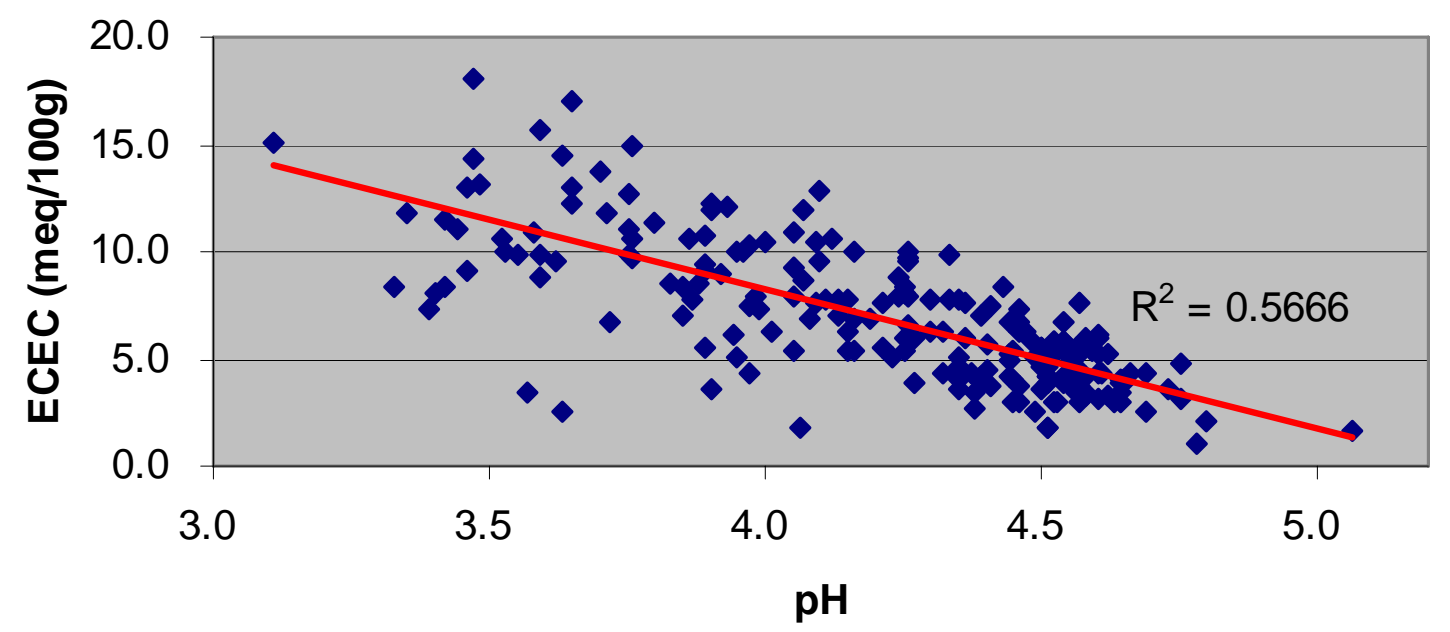

Figure 3.1. The relationship between soil $\mathrm{pH}$ and effective cation exchange capacity (ECEC) for both project areas in the Cherry River watershed. The slope of the regression line is significantly different than zero.

Soil pH in the Cherry River watershed increased with depth (Figure 3.2). This pattern is explained by the incorporation of organic matter and deposition of acids to the surface. Organic matter inputs provide nutrients as well as organic acids to the soil (Brady and Weil, 2002; Johnson, 2002). The lower soil horizons apparently have retained nutrients as a result of the weathering process and accumulation from leaching from higher horizons. Typically, the $\mathrm{pH}$ of most soils in the northeast decrease with depth due to the low base status parent material of the region (Drohan and Sharpe, 1997). The increase with depth suggests that the majority of acidic inputs to the soils came from acidic deposition and biochemical processes occurring near the soil surface. 


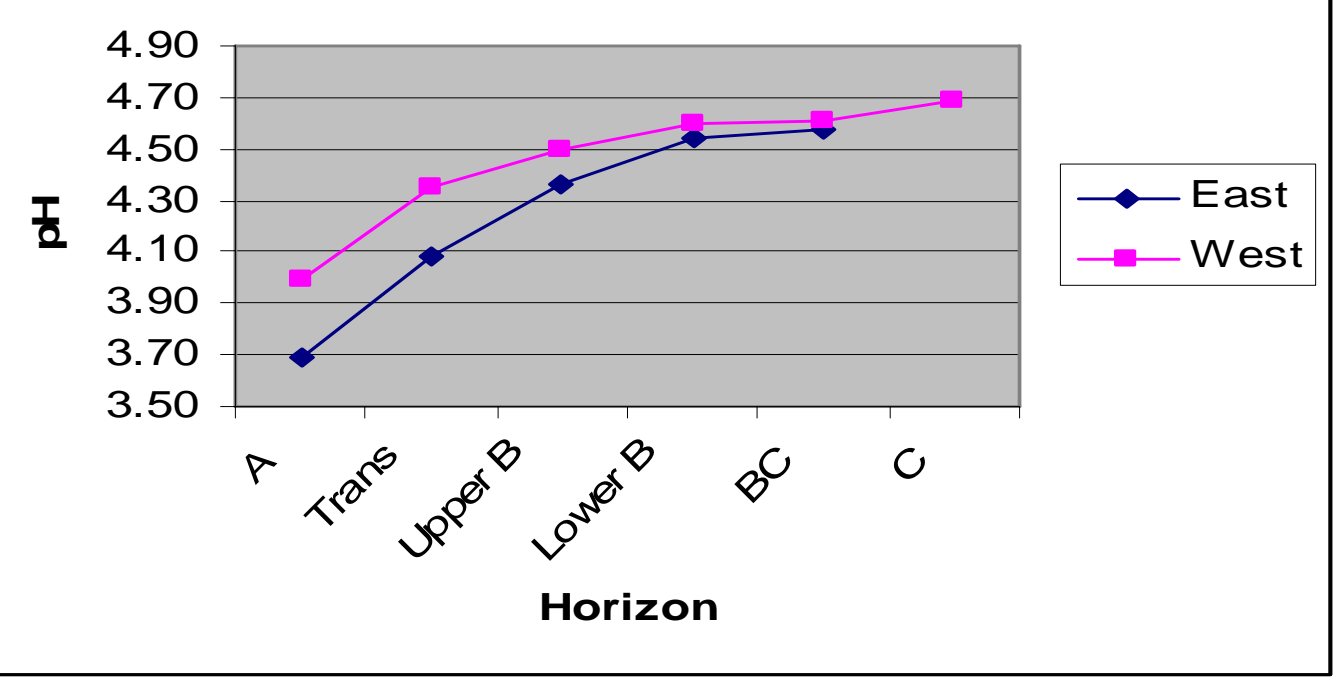

\section{Figure 3.2. Soil pH with depth for both project areas.}

\section{Base Cations}

Base cations are the weak acid cations found on soil exchange sites. These cations are calcium, magnesium, potassium, and sodium. Calcium was the dominant base cation in these soils, and potassium was the second most abundant (Table 3.2).

The east area had higher concentrations than the west of each cation in the upper three horizons, but the only significant difference in the A horizon was magnesium concentration. Calcium, magnesium, and potassium were all significantly different between areas in the transition horizon. Magnesium, potassium, and sodium were significantly different between areas in the upper B horizon. In the lower B and BC horizons, the west area had higher values of calcium, magnesium, and sodium. This pattern could be attributed to the higher base status parent material found in the west area. Also, the composition of tree species from east to west in the watershed may have affected the base cation concentrations (Prescott, 2002). Maple species, especially sugar maple, which are more prevalent in the east area, have higher amounts of the base cations 
in leaf litter than oak species (Washburn and Arthur, 2003), which are more common in the west area (see Table 1.4).

Table 3.2. Mean base cation concentrations by horizon compared between watershed areas.

\begin{tabular}{llcccc}
\hline Area & Horizon & Ca & Mg & K & Na \\
\cline { 3 - 6 } & & \multicolumn{4}{c}{$\mathbf{~ m g ~ k g}^{-1}$} \\
\cline { 3 - 6 } & Range & $8.0-905.3$ & 120.7 & $12.4-$ & $2.0-$ \\
\hline East & A & $160.4+$ & $36.7+^{*}$ & $79.8+$ & $12.4+$ \\
West & A & $136.7+$ & $26.5+^{*}$ & $77.9+$ & $11.6+$ \\
\hline East & Transition & $44.9^{*}$ & $14.5^{* *}$ & $45.4^{*}$ & 8.2 \\
West & Transition & $41.3^{*}$ & $8.2^{* *}$ & $40.2^{*}$ & 7.8 \\
\hline East & Upper B & $34.9+$ & $10.2+^{*}$ & $36.4^{*}$ & $8.6+^{* *}$ \\
West & Upper B & $28.3+$ & $6.2+^{*}$ & $30 .+^{*}$ & $6.1+^{* *}$ \\
\hline East & Lower B & 19.6 & 5.9 & 36.4 & 5.7 \\
West & Lower B & 25.1 & 11.0 & 30.8 & 5.9 \\
\hline East & BC & 24.9 & 9.0 & 36.5 & 5.8 \\
West & BC & 37.4 & 11.5 & 29.5 & 4.4 \\
\hline East & C & -- & -- & -- & -- \\
West & C & 42.2 & 22.2 & 17.77 & 3.3 \\
\hline shy
\end{tabular}

$*$ shows significant difference between project areas at $\alpha=0.05$.

** shows significant difference between project areas at $\alpha=0.0001$.

+ shows significant difference between $A$ and Upper $B$ horizon at $\alpha=0.05$.

All four base cations were significantly different between the A and upper B

horizons in both the east and west areas. Calcium and magnesium both decreased initially with depth and then increased in the lowest two horizons. Jenkins (2000) also found that calcium and magnesium decreased with depth in soils formed from the Pottsville geology. Calcium and magnesium sources for these soils were litter fall, parent material weathering, and ambient deposition (Jenkins, 2002; Johnson and Todd, 1990). Potassium and sodium decreased with depth throughout the entire profile.

\section{Acid Cations}

The acid cations included aluminum (Al), iron (Fe), and manganese (Mn). Aluminum and iron were significantly higher in the east area than the west area for the 
upper three horizons (Table 3.3). This difference also occurred for the lower B and BC horizons. No differences were found for manganese.

The acid cations were significantly higher in the A horizon than the upper B horizon in both areas. Aluminum and iron decreased with depth throughout the soil profile, while manganese generally decreased with depth but without the consistency of aluminum and iron. The aluminum and iron decreases were partially explained by the $\mathrm{pH}$ and acidity of the soils (Figure 3.3). As pH decreases below 5.5, aluminum controls the acidity and ECEC of a soil system (Skyllberg, 1999). Between pH 4.0 and 5.5, hydrolysis and dissolution of aluminum and iron hydroxyoxide minerals occurs (Skyllberg, 1999). These processes release iron and aluminum oxides into the soil solution. The low $\mathrm{pH}$ range of 3.0-5.0 in these soils promoted these reactions, thus releasing increasingly greater quantities of aluminum and iron. The east area had a lower $\mathrm{pH}$ and higher acidity content than the west area that corresponded to higher aluminum and iron contents (Table 3.3). Jenkins (2000) found similar results on soils formed from the same geology in other areas of West Virginia. 
Table 3.3. Mean acid cation concentrations by horizon compared between watershed areas.

\begin{tabular}{lcccc}
\hline Area & Horizon & $\mathbf{A l}$ & $\mathbf{F e}$ & $\mathbf{M n}$ \\
\cline { 3 - 5 } & & & $\mathbf{m g ~ k g}^{-1}$ & \\
\cline { 3 - 5 } & & $27.3-$ & $0.3-$ & $0.3-$ \\
& Range & 1142.1 & 142.7 & 223.2 \\
\hline East & A & $650.1+* *$ & $50.9^{* *}$ & $44.7+$ \\
West & A & $538.1^{* *}$ & $23.4^{* *}$ & $77.1+$ \\
\hline East & Transition & $616.5^{* *}$ & $30.1^{* *}$ & 13.9 \\
West & Transition & $335.3^{* *}$ & $4.3^{* *}$ & 17.3 \\
\hline East & Upper B & $500.5+* *$ & $14.7+^{* *}$ & $9.5+$ \\
West & Upper B & $324.7+* *$ & $5.2+^{* *}$ & $4.9+$ \\
\hline East & Lower B & 355.6 & 3.3 & 7.2 \\
West & Lower B & 295.1 & 4.0 & 4.6 \\
\hline East & BC & 303.10 & 3.3 & 11.8 \\
West & BC & 248.5 & 3.3 & 11.8 \\
\hline East & C & -- & -- & -- \\
West & C & 112.8 & 3.9 & 3.7 \\
\hline
\end{tabular}

* shows significant difference between project areas at $\alpha=0.05$.

$* *$ shows significant difference between project areas at $\alpha=0.0001$.

+ shows significant difference between $A$ and Upper $B$ horizon at $\alpha=0.05$.

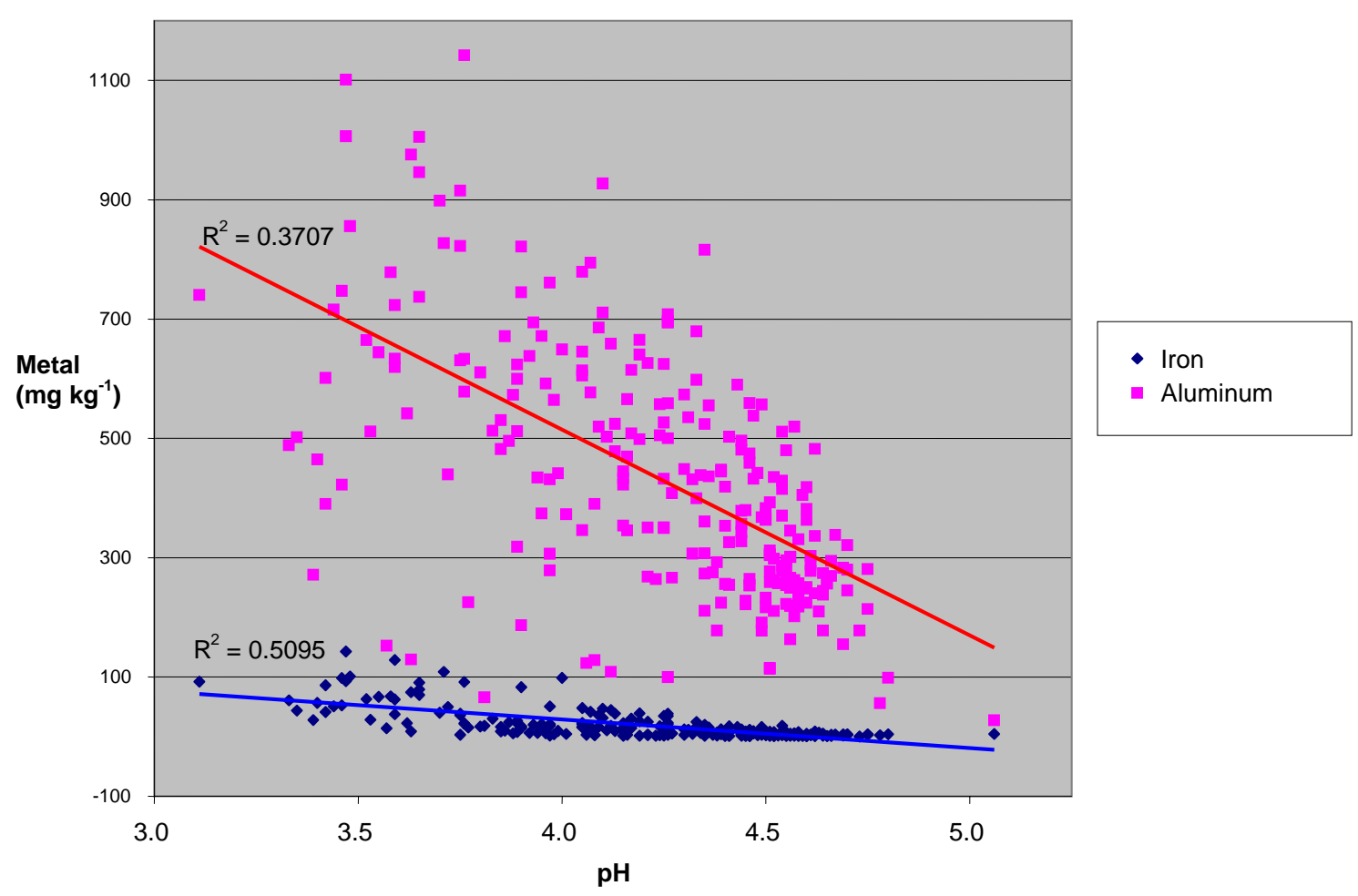

Figure 3.3. Iron and aluminum relationships with soil $\mathrm{pH}$ for both east and west areas. The slopes of both regression lines are significantly different than zero. 


\section{Carbon and Nitrogen}

Table 3.4 shows the mean percentages of carbon and nitrogen by horizon for both project areas. As is common for most soils, the organic matter content was highest at the surface and decreased with depth in the soil profile (Yang et al., 2004). LOI, TC, and TN were all significantly different between the A and upper B horizons in both areas.

The east area had significantly higher amounts of organic matter (LOI), total organic carbon, and total organic nitrogen in the upper three horizons compared to the west area. Higher values also continued in the lower B and BC horizons. The higher organic matter content in the east area could be attributed to lower soil temperatures.

Table 3.4. Mean carbon and nitrogen by horizon for both watershed areas.

\begin{tabular}{llccc}
\hline Area & Horizon & LOI & TN & TC \\
\hline & & \multicolumn{3}{c}{$\%$} \\
\cline { 3 - 5 } & & $1.0-$ & $0.1-$ \\
& Range & 34.0 & $0.0-0.9$ & 18.5 \\
\hline East & $\mathrm{A}$ & $15.8+^{*}$ & $0.5+^{*}$ & $7.5+^{*}$ \\
West & $\mathrm{A}$ & $15.6+^{*}$ & $0.4+^{*}$ & $8.1+^{*}$ \\
\hline East & Transition & $8.6^{*}$ & $0.2^{*}$ & $3.4^{*}$ \\
West & Transition & $6.6^{*}$ & $0.1^{*}$ & $2.6^{*}$ \\
\hline East & Upper B & $7.2+^{* *}$ & $0.2+^{* *}$ & $2.4+^{* *}$ \\
West & Upper B & $4.5+^{*}$ & $0.1+^{* *}$ & $1.3+^{* *}$ \\
\hline East & Lower B & 5.3 & 0.1 & 1.3 \\
West & Lower B & 3.8 & 0.1 & 0.6 \\
\hline East & BC & 4.2 & 0.1 & 0.7 \\
West & BC & 2.9 & 0.0 & 0.3 \\
\hline East & C & -- & - & -- \\
West & $\mathrm{C}$ & 1.5 & 0.0 & 0.3 \\
\hline * shows significant difference between project areas at $\boldsymbol{\alpha}=\mathbf{0 . 0 5 .}$ \\
** shows significant difference between project areas at $\boldsymbol{\alpha}=\mathbf{0 . 0 0 0 1}$ \\
+ shows significant difference between A and Upper B horizon at $\boldsymbol{\alpha}=\mathbf{0 . 0 5}$.
\end{tabular}

The frigid soil temperatures in the east area should have slowed biological processes including organic matter decomposition (Brady and Weil, 2002; Miller et al., 2004). As a result, organic matter accumulated in the east. In the Appalachian Mountains in Virginia, 
similar results were found with frigid soils having higher organic matter accumulation and incorporation (Miller et al., 2004).

\section{Landscape Position}

East Area

Chemical Properties

The east area soil acidity parameters showed only one possible difference for the landscape positions (Table 3.5). The lower horizons of the floodplain soils appeared to have a higher BSECEC than the other landscape positions. This possibly was due to buried surface horizons in the floodplain soils. Surface horizons typically have higher organic matter content providing base cations.

Table 3.5. Mean soil acidity parameters for the east area landscape positions.

\begin{tabular}{llcccc}
\hline \multicolumn{1}{c}{$\begin{array}{c}\text { Landscape } \\
\text { Position }\end{array}$} & Horizon & Soil pH & $\begin{array}{c}\text { Acidity } \\
\text { meq 100g-1 }\end{array}$ & $\begin{array}{c}\text { ECEC } \\
\text { meq 100g }\end{array}$ & $\begin{array}{c}\text { BSECEC } \\
\text { \% }\end{array}$ \\
\hline Ridge & Range & $3.1-5.1$ & $0.4-16.4$ & $1.1-27.3$ & $2.1-75.0$ \\
Shoulder & A & 3.6 & 8.7 & 10.3 & 16.7 \\
Back slope & A & 3.8 & 9.6 & 10.9 & 11.6 \\
Bench & A & 3.7 & 9.0 & 10.9 & 16.3 \\
Foot slope & A & 3.8 & 8.4 & 9.3 & 10.9 \\
Floodplain & A & 3.7 & 8.7 & 9.8 & 11.6 \\
\hline Ridge & Transition & 3.7 & 11.2 & 12.7 & 11.8 \\
Shoulder & Transition & 4.2 & 9.3 & 9.9 & 6.8 \\
Back slope & Transition & 4.1 & 8.0 & 8.5 & 5.9 \\
Bench & Transition & 4.1 & 7.9 & 9.2 & 5.3 \\
Foot slope & Transition & 3.9 & 8.9 & 8.3 & 5.8 \\
Floodplain & Transition & 4.1 & 8.5 & 9.4 & 4.7 \\
\hline Ridge & Upper B & 4.4 & 7.2 & 7.7 & 7.6 \\
Shoulder & Upper B & 4.3 & 7.7 & 8.1 & 6.9 \\
Back slope & Upper B & 4.4 & 6.3 & 6.6 & 5.7 \\
Bench & Upper B & 4.4 & 5.9 & 6.3 & 6.2 \\
Foot slope & Upper B & 4.2 & 7.1 & 7.5 & 4.5 \\
Floodplain & Upper B & 4.2 & 8.3 & 8.7 & 6.3 \\
\hline Ridge & Lower Horizons & 4.5 & 5.5 & 5.7 & 4.0 \\
Shoulder & Lower Horizons & 4.6 & 5.2 & 5.6 & 6.6 \\
Back slope & Lower Horizons & 4.6 & 4.3 & 4.6 & 5.6 \\
Bench & Lower Horizons & 4.5 & 5.8 & 6.2 & 5.2 \\
Foot slope & Lower Horizons & 4.6 & 3.4 & 3.6 & 6.6 \\
Floodplain & Lower Horizons & 4.7 & 2.8 & 3.6 & 22.1 \\
\hline
\end{tabular}


The floodplain soils in the east area also appeared to have higher concentrations of calcium and magnesium in the lower horizons of the soil (Table 3.6). This was possibly also due to buried horizons in the floodplain soils.

Table 3.6. Mean base cation concentrations for the east area landscape positions.

\begin{tabular}{llcccc}
\hline $\begin{array}{l}\text { Landscape } \\
\text { Position }\end{array}$ & Horizon & Ca & Mg & K & Na \\
\hline & & \multicolumn{4}{c}{$\mathbf{m g ~ k g}^{-1}$} \\
\cline { 3 - 6 } & & $7.8-$ & $2.0-$ & $12.4-$ & \\
& Range & 905.3 & 120.7 & 206.4 & $2.0-35.2$ \\
\hline Ridge & $\mathrm{A}$ & 204.1 & 35.2 & 88.2 & 11.5 \\
Shoulder & $\mathrm{A}$ & 133.3 & 42.3 & 90.5 & 12.2 \\
Back slope & $\mathrm{A}$ & 248.5 & 50.2 & 84.6 & 13.7 \\
Bench & $\mathrm{A}$ & 101.2 & 26.3 & 69.2 & 9.3 \\
Foot slope & $\mathrm{A}$ & 121.0 & 30.5 & 74.4 & 11.3 \\
Floodplain & $\mathrm{A}$ & 178.6 & 42.1 & 79.4 & 15.8 \\
\hline Ridge & Transition & 72.9 & 14.8 & 48.4 & 9.3 \\
Shoulder & Transition & 40.9 & 15.2 & 54.9 & 7.1 \\
Back slope & Transition & 40.1 & 14.5 & 45.3 & 7.7 \\
Bench & Transition & 36.4 & 11.1 & 40.5 & 7.9 \\
Foot slope & Transition & 37.0 & 12.0 & 46.4 & 8.5 \\
Floodplain & Transition & 49.9 & 21.1 & 45.6 & 7.2 \\
\hline Ridge & Upper B & 55.4 & 9.4 & 40.8 & 11.6 \\
Shoulder & Upper B & 26.2 & 10.0 & 40.0 & 6.8 \\
Back slope & Upper B & 26.3 & 8.3 & 35.7 & 8.6 \\
Bench & Upper B & 36.3 & 7.9 & 33.6 & 9.1 \\
Foot slope & Upper B & 25.8 & 7.6 & 37.1 & 8.1 \\
Floodplain & Upper B & 37.0 & 14.5 & 40.0 & 7.7 \\
\hline Ridge & Lower Horizons & 13.7 & 3.8 & 39.2 & 6.3 \\
Shoulder & Lower Horizons & 29.9 & 11.5 & 41.6 & 3.8 \\
Back slope & Lower Horizons & 20.9 & 4.8 & 27.8 & 8.4 \\
Bench & Lower Horizons & 20.3 & 7.2 & 54.3 & 6.0 \\
Foot slope & Lower Horizons & 18.7 & 4.2 & 33.3 & 5.2 \\
Floodplain & Lower Horizons & 76.3 & 36.1 & 39.4 & 3.8 \\
\hline & & & & & \\
\hline & & & & \\
& & & &
\end{tabular}

Floodplain soils appeared to have higher concentrations of manganese in the lower horizons than the other landscape positions (Table 3.7). As the floodplain soils were saturated for a large portion of the year, the oxidation-reduction nature of 
manganese caused a higher concentration of this metal in the soil because manganese is more available to the soil solution in its reduced state (Brady and Weil, 2002; Singer and Havill, 1985).

Table 3.7. Mean acid cation concentrations for the east area landscape positions.

\begin{tabular}{|c|c|c|c|c|}
\hline $\begin{array}{l}\text { Landscape } \\
\text { Position }\end{array}$ & Horizon & Al & $\mathbf{F e}$ & Mn \\
\hline \multirow{2}{*}{\multicolumn{2}{|c|}{ Range }} & \multicolumn{3}{|c|}{$\mathrm{mg} \mathrm{kg}^{-1}$} \\
\hline & & $\begin{array}{l}27.3- \\
1142.1\end{array}$ & $\begin{array}{l}0.3- \\
142.7\end{array}$ & $\begin{array}{l}0.3- \\
223.2\end{array}$ \\
\hline Ridge & $\mathrm{A}$ & 573.9 & 41.6 & 54.5 \\
\hline Shoulder & A & 693.8 & 48.7 & 45.4 \\
\hline Back slope & A & 623.5 & 47.0 & 51.9 \\
\hline Bench & A & 577.8 & 30.7 & 40.8 \\
\hline Foot slope & A & 593.4 & 45.8 & 54.2 \\
\hline Floodplain & A & 797.5 & 78.3 & 38.4 \\
\hline Ridge & Transition & 663.6 & 30.6 & 11.8 \\
\hline Shoulder & Transition & 568.7 & 14.4 & 15.5 \\
\hline Back slope & Transition & 647.7 & 25.9 & 16.6 \\
\hline Bench & Transition & 548.1 & 26.9 & 11.5 \\
\hline Foot slope & Transition & 680.9 & 44.6 & 5.9 \\
\hline Floodplain & Transition & 623.9 & 35.4 & 28.2 \\
\hline Ridge & Upper B & 550.4 & 13.2 & 9.7 \\
\hline Shoulder & Upper B & 546.7 & 17.7 & 5.9 \\
\hline Back slope & Upper B & 476.4 & 8.0 & 7.9 \\
\hline Bench & Upper B & 435.4 & 10.9 & 7.6 \\
\hline Foot slope & Upper B & 521.5 & 14.5 & 10.4 \\
\hline Floodplain & Upper B & 548.3 & 23.0 & 14.8 \\
\hline Ridge & Lower Horizons & 445.9 & 4.7 & 3.1 \\
\hline Shoulder & Lower Horizons & 372.4 & 1.8 & 16.0 \\
\hline Back slope & Lower Horizons & 313.4 & 4.6 & 5.9 \\
\hline Bench & Lower Horizons & 426.2 & 2.6 & 9.1 \\
\hline Foot slope & Lower Horizons & 258.5 & 2.5 & 3.6 \\
\hline Floodplain & Lower Horizons & 178.0 & 0.3 & 40.2 \\
\hline
\end{tabular}

There were no apparent differences in the carbon and nitrogen parameters for the east area landscape positions (Table 3.8). 
Table 3.8. Mean carbon and nitrogen for the east area landscape positions.

\begin{tabular}{llccc}
\hline $\begin{array}{l}\text { Landscape } \\
\text { Position }\end{array}$ & Horizon & $\begin{array}{c}\text { LOI } \\
\text { \% }\end{array}$ & $\begin{array}{c}\text { TN } \\
\mathbf{\%}\end{array}$ & $\begin{array}{c}\text { TC } \\
\mathbf{\%}\end{array}$ \\
\hline & Range & $1.0-34.0$ & $0.1-0.3$ & $0.1-18.5$ \\
\hline Ridge & A & 15.2 & 0.5 & 7.2 \\
Shoulder & A & 15.4 & 0.5 & 6.6 \\
Back slope & A & 17.4 & 0.5 & 8.1 \\
Bench & A & 14.3 & 0.5 & 7.4 \\
Foot slope & A & 13.3 & 0.4 & 6.2 \\
Floodplain & A & 19.9 & 0.6 & 9.8 \\
\hline Ridge & Transition & 9.0 & 0.2 & 3.7 \\
Shoulder & Transition & 7.1 & 0.2 & 2.1 \\
Back slope & Transition & 8.4 & 0.2 & 3.1 \\
Bench & Transition & 8.6 & 0.2 & 4.1 \\
Foot slope & Transition & 7.3 & 0.2 & 2.6 \\
Floodplain & Transition & 10.8 & 0.3 & 4.3 \\
\hline Ridge & Upper B & 8.2 & 0.2 & 2.7 \\
Shoulder & Upper B & 6.5 & 0.1 & 1.7 \\
Back slope & Upper B & 6.8 & 0.2 & 2.1 \\
Bench & Upper B & 7.4 & 0.2 & 2.6 \\
Foot slope & Upper B & 6.4 & 0.2 & 1.9 \\
Floodplain & Upper B & 8.8 & 0.2 & 3.4 \\
\hline Ridge & Lower Horizons & 4.8 & 0.1 & 0.9 \\
Shoulder & Lower Horizons & 4.4 & 0.1 & 0.6 \\
Back slope & Lower Horizons & 5.1 & 0.1 & 1.1 \\
Bench & Lower Horizons & 7.0 & 0.1 & 2.0 \\
Foot slope & Lower Horizons & 3.6 & 0.1 & 0.6 \\
Floodplain & Lower Horizons & 2.7 & 0.0 & 0.4 \\
\hline & & & & \\
\hline
\end{tabular}

\section{West Area}

\section{Chemical Properties}

The lower horizons of the floodplain soils appeared to have a higher BSECEC than the other landscape positions (Table 3.9). This possibly was due to buried horizons in the soil. 
Table 3.9. Mean soil acidity for the west area landscape positions.

\begin{tabular}{|c|c|c|c|c|c|}
\hline $\begin{array}{c}\text { Landscape } \\
\text { Position } \\
\end{array}$ & Horizon & Soil pH & $\begin{array}{c}\text { Acidity } \\
\text { meq } 100 g^{-1}\end{array}$ & $\begin{array}{c}\text { ECEC } \\
\operatorname{meq}^{100 g^{-1}}\end{array}$ & $\begin{array}{c}\text { BSECEC } \\
\% \\
\end{array}$ \\
\hline \multicolumn{2}{|c|}{ Range } & $3.1-5.1$ & $0.4-16.4$ & $1.1-27.3$ & $2.1-75.0$ \\
\hline Ridge & $\mathrm{A}$ & 3.8 & 7.8 & 9.0 & 13.4 \\
\hline Shoulder & A & 3.9 & 5.8 & 6.5 & 11.6 \\
\hline Back slope & A & 4.2 & 6.5 & 7.6 & 14.5 \\
\hline Bench & $\mathrm{A}$ & 4.1 & 6.2 & 7.8 & 20.7 \\
\hline Foot slope & A & 4.0 & 6.9 & 8.1 & 14.1 \\
\hline Floodplain & $\mathrm{A}$ & 4.1 & 3.5 & 4.2 & 15.9 \\
\hline Ridge & Transition & 4.4 & 5.1 & 5.5 & 7.8 \\
\hline Shoulder & Transition & 4.3 & 4.1 & 4.4 & 6.7 \\
\hline Back slope & Transition & 4.5 & 3.8 & 4.2 & 8.7 \\
\hline Bench & Transition & 4.4 & 4.6 & 5.1 & 8.9 \\
\hline Foot slope & Transition & 4.2 & 5.9 & 6.3 & 6.6 \\
\hline Floodplain & Transition & 4.3 & 2.4 & 2.6 & 8.9 \\
\hline Ridge & Upper B & 4.5 & 4.3 & 4.6 & 6.6 \\
\hline Shoulder & Upper B & 4.4 & 3.4 & 3.7 & 6.9 \\
\hline Back slope & Upper B & 4.6 & 3.5 & 3.8 & 8.0 \\
\hline Bench & Upper B & 4.6 & 4.1 & 4.5 & 7.0 \\
\hline Foot slope & Upper B & 4.5 & 4.2 & 4.4 & 5.6 \\
\hline Floodplain & Upper B & 4.4 & 2.3 & 2.5 & 7.8 \\
\hline Ridge & Lower Horizons & 4.5 & 3.3 & 3.6 & 7.3 \\
\hline Shoulder & Lower Horizons & 4.4 & 3.4 & 3.6 & 4.4 \\
\hline Back slope & Lower Horizons & 4.5 & 2.3 & 2.5 & 7.5 \\
\hline Bench & Lower Horizons & 4.6 & 4.0 & 4.4 & 9.8 \\
\hline Foot slope & Lower Horizons & 4.7 & 4.1 & 4.8 & 13.2 \\
\hline Floodplain & Lower Horizons & 4.7 & 2.2 & 2.7 & 28.5 \\
\hline
\end{tabular}

There were no apparent differences among landscape positions for base cations in the west area (Table 3.10), and no apparent differences among landscape positions for acid cations in the west area (Table 3.11). 
Table 3.10. Mean base cation concentrations for the west area landscape positions.

\begin{tabular}{|c|c|c|c|c|c|}
\hline $\begin{array}{l}\text { Landscape } \\
\text { Position }\end{array}$ & Horizon & $\mathbf{C a}$ & Mg & $\mathbf{K}$ & $\mathbf{N a}$ \\
\hline & & \multicolumn{4}{|c|}{$\mathrm{mg} \mathrm{kg}^{-1}$} \\
\hline & nge & $\begin{array}{l}8.0- \\
905.3 \\
\end{array}$ & $\begin{array}{l}2.0- \\
120.7 \\
\end{array}$ & $\begin{array}{l}12.4- \\
206.4 \\
\end{array}$ & $2.0-35.2$ \\
\hline Ridge & $\mathrm{A}$ & 136.7 & 26.5 & 77.9 & 11.6 \\
\hline Shoulder & A & 69.6 & 20.5 & 53.5 & 8.2 \\
\hline Back slope & A & 127.8 & 25.5 & 72.2 & 11.7 \\
\hline Bench & A & 213.2 & 33.0 & 78.5 & 10.3 \\
\hline Foot slope & A & 149.0 & 28.1 & 53.6 & 9.7 \\
\hline Floodplain & A & 80.8 & 18.4 & 37.4 & 7.7 \\
\hline Ridge & Transition & 40.3 & 8.9 & 40.7 & 7.9 \\
\hline Shoulder & Transition & 26.7 & 7.1 & 30.8 & 5.6 \\
\hline Back slope & Transition & 33.0 & 8.6 & 37.3 & 7.5 \\
\hline Bench & Transition & 51.6 & 11.4 & 41.6 & 6.8 \\
\hline Foot slope & Transition & 44.9 & 8.2 & 37.6 & 8.0 \\
\hline Floodplain & Transition & 21.0 & 5.3 & 19.5 & 4.3 \\
\hline Ridge & Upper B & 28.3 & 6.2 & 30.0 & 6.1 \\
\hline Shoulder & Upper B & 23.7 & 5.1 & 26.2 & 5.5 \\
\hline Back slope & Upper B & 26.2 & 6.3 & 33.1 & 7.3 \\
\hline Bench & Upper B & 29.9 & 6.2 & 35.0 & 6.4 \\
\hline Foot slope & Upper B & 23.5 & 4.3 & 24.7 & 6.2 \\
\hline Floodplain & Upper B & 16.9 & 3.9 & 17.8 & 3.7 \\
\hline Ridge & Lower Horizons & 29.3 & 5.1 & 22.2 & 4.6 \\
\hline Shoulder & Lower Horizons & 8.8 & 4.3 & 25.8 & 2.3 \\
\hline Back slope & Lower Horizons & 16.8 & 3.9 & 18.9 & 3.3 \\
\hline Bench & Lower Horizons & 26.0 & 22.9 & 36.1 & 4.4 \\
\hline Foot slope & Lower Horizons & 75.3 & 13.6 & 41.3 & 5.1 \\
\hline Floodplain & Lower Horizons & 53.4 & 23.5 & 23.1 & 4.7 \\
\hline
\end{tabular}


Table 3.11. Mean acid cation concentrations for the west area landscape positions.

\begin{tabular}{|c|c|c|c|c|}
\hline $\begin{array}{l}\text { Landscape } \\
\text { Position } \\
\end{array}$ & Horizon & Al & $\mathbf{F e}$ & Mn \\
\hline \multirow{2}{*}{\multicolumn{2}{|c|}{ Range }} & \multicolumn{3}{|c|}{$\mathrm{mg} \mathrm{kg}^{-1}$} \\
\hline & & $\begin{array}{l}27.3- \\
1142.1 \\
\end{array}$ & $\begin{array}{l}0.3- \\
142.7\end{array}$ & $\begin{array}{l}0.3- \\
223.2\end{array}$ \\
\hline Ridge & $\mathrm{A}$ & 538.2 & 23.4 & 77.1 \\
\hline Shoulder & A & 405.1 & 28.1 & 40.0 \\
\hline Back slope & A & 475.6 & 15.0 & 65.9 \\
\hline Bench & $\mathrm{A}$ & 414.9 & 9.1 & 84.4 \\
\hline Foot slope & $\mathrm{A}$ & 490.6 & 13.8 & 59.1 \\
\hline Floodplain & A & 267.4 & 12.0 & 32.5 \\
\hline Ridge & Transition & 381.8 & 8.5 & 15.9 \\
\hline Shoulder & Transition & 288.3 & 8.6 & 15.1 \\
\hline Back slope & Transition & 293.0 & 5.0 & 14.9 \\
\hline Bench & Transition & 333.1 & 8.1 & 22.5 \\
\hline Foot slope & Transition & 405.2 & 7.4 & 17.9 \\
\hline Floodplain & Transition & 181.7 & 3.8 & 13.6 \\
\hline Ridge & Upper B & 324.7 & 5.2 & 4.9 \\
\hline Shoulder & Upper B & 240.7 & 5.6 & 7.0 \\
\hline Back slope & Upper B & 262.1 & 4.3 & 9.3 \\
\hline Bench & Upper B & 298.7 & 2.7 & 6.9 \\
\hline Foot slope & Upper B & 290.4 & 3.5 & 6.6 \\
\hline Floodplain & Upper B & 154.1 & 3.2 & 10.0 \\
\hline Ridge & Lower Horizons & 254.9 & 5.9 & 2.2 \\
\hline Shoulder & Lower Horizons & 273.3 & 7.1 & 0.7 \\
\hline Back slope & Lower Horizons & 181.5 & 3.6 & 0.3 \\
\hline Bench & Lower Horizons & 262.6 & 1.6 & 6.9 \\
\hline Foot slope & Lower Horizons & 300.1 & 1.8 & 12.4 \\
\hline Floodplain & Lower Horizons & 129.6 & 3.4 & 19.3 \\
\hline
\end{tabular}

There also were no apparent differences among landscape positions for carbon and nitrogen parameters for the west area (Table 3.12). 
Table 3.12. Mean carbon and nitrogen parameters for the west area landscape positions.

\begin{tabular}{llccc}
\hline $\begin{array}{l}\text { Landscape } \\
\text { Position }\end{array}$ & Horizon & $\begin{array}{c}\text { LOI } \\
\mathbf{\%}\end{array}$ & $\begin{array}{c}\text { TN } \\
\mathbf{\%}\end{array}$ & $\begin{array}{c}\text { TC } \\
\mathbf{\%}\end{array}$ \\
\hline Ridge & Range & $1.0-34.0$ & $0.0-1.0$ & $0.1-18.5$ \\
Shoulder & $\mathrm{A}$ & 15.6 & 0.4 & 8.1 \\
Back slope & $\mathrm{A}$ & 9.4 & 0.3 & 5.0 \\
Bench & $\mathrm{A}$ & 12.9 & 0.4 & 6.6 \\
Foot slope & $\mathrm{A}$ & 12.5 & 0.4 & 6.4 \\
Floodplain & $\mathrm{A}$ & 9.5 & 0.3 & 4.6 \\
\hline Ridge & $\mathrm{A}$ & 6.4 & 0.2 & 3.5 \\
Shoulder & Transition & 7.3 & 0.2 & 3.0 \\
Back slope & Transition & 5.5 & 0.1 & 2.5 \\
Bench & Transition & 6.9 & 0.2 & 2.7 \\
Foot slope & Transition & 6.8 & 0.2 & 2.8 \\
Floodplain & Transition & 6.7 & 0.2 & 2.4 \\
\hline Ridge & Transition & 3.2 & 0.1 & 1.5 \\
Shoulder & Upper B & 4.5 & 0.1 & 1.3 \\
Back slope & Upper B & 4.1 & 0.1 & 1.4 \\
Bench & Upper B & 5.4 & 0.1 & 1.7 \\
Foot slope & Upper B & 4.7 & 0.1 & 1.3 \\
Floodplain & Upper B & 4.4 & 0.1 & 1.2 \\
\hline Ridge & Upper B & 2.9 & 0.1 & 1.2 \\
Shoulder & Lower Horizons & 2.2 & 0.0 & 0.3 \\
Back slope & Lower Horizons & 2.3 & 0.0 & 0.4 \\
Bench & Lower Horizons & 1.7 & 0.0 & 0.1 \\
Foot slope & Lower Horizons & 3.9 & 0.0 & 0.2 \\
Floodplain & Lower Horizons & 3.8 & 0.1 & 0.4 \\
\hline & Lower Horizons & 2.5 & 0.1 & 0.6 \\
\hline
\end{tabular}




\section{Conclusions}

The general soil chemistry for the Cherry River watershed showed some definite trends with acid-base implications. The east area was higher in nutrient and organic matter content but also higher in acidity and acid cations, which is explained by the frigid soil temperature and higher organic matter content. There were very few possible differences seen with the landscape positions for either area. However, the buried horizons of the floodplain soils in both areas had higher BSECEC than the lower horizons of the soils in other landscape positions. 


\section{Chapter 4. Soil Classification}

Using the data presented in the previous two chapters, the full characterization pits were classified to the Subgroup level of Soil Taxonomy (Soil Survey Staff, 1975) (Table 4.1). Due to the lack of cation exchange capacity data required by Soil Taxonomy, the soils were not classified to the family level. An assumption was made in order to classify the soils to the Subgroup level. The assumption was that the soils had a base saturation of the cation exchange capacity of less than 35\%. This assumption was based on the methods used to determine BSECEC of the soils (see Chapter 1, page 27). The BSECEC was much less than $35 \%$ for all of the soils, and therefore the base saturation of the cation exchange capacity (which is used in Soil Survey procedures) was assumed to be less than $35 \%$ as well.

All but two of the soils were Inceptisols (Table 4.1). Only two argillic horizons were found in the soils. Both of these argillic horizons were found in the east area, one ridge and one shoulder soil. These soils were classified to Typic Hapludults and Typic Fragiudults, respectively. The most common Subgroup was Typic Dystrudepts (6 soils). The second most common Subgroup was the Typic Fragiudepts (3 soils) followed by Fragic Dystrudepts (2 soils). The floodplain soils and one foot slope soil had different classifications than the other soils: Oxyaquic Dystrudepts and Fluventic Dystrudepts for the floodplain soils, and Aquic Dystrudepts for the wet foot slope soil (Table 4.1). Overall, the Subgroup classification of the soils were similar throughout the watershed, with all the soils classifying as low base saturation soils with weak development of diagnostic horizons. 
While the soils were only classified to the Subgroup level, two family level classes were determined: particle size class and soil temperature class (Table 4.1). Mount and Paetzold (2002) determined soil temperatures for both project areas; the east area soils were determined to be frigid while the west area soils were found to be mesic. The particle size classes of the watershed were similar, though the west area had more rock fragments.

Table 4.1. Subgroup classification and family classes for the Cherry River watershed soils.

\begin{tabular}{|c|c|c|c|c|c|}
\hline $\begin{array}{l}\text { Project } \\
\text { Area }\end{array}$ & $\begin{array}{l}\text { Landscape } \\
\text { Position }\end{array}$ & Site ID & Subgroup & $\begin{array}{l}\text { Particle } \\
\text { Size Class }\end{array}$ & $\begin{array}{l}\text { Soil Temp. } \\
\text { Class }\end{array}$ \\
\hline East & Back slope & FS04WV025001 & Typic Dystrudepts & Fine-loamy & Frigid \\
\hline East & Back slope & FS04WV025002 & Typic Dystrudepts & Fine-loamy & Frigid \\
\hline East & Ridge & FS04WV025003 & Typic Fragiudepts & Fine-loamy & Frigid \\
\hline East & Foot slope & FS04WV025004 & Fragic Dystrudepts & Fine-loamy & Frigid \\
\hline East & Bench & FS04WV025005 & Typic Fragiudepts & Fine-loamy & Frigid \\
\hline East & Shoulder & FS04WV025010 & Typic Fragiudults & Fine-loamy & Frigid \\
\hline East & Floodplain & FS04WV025019 & $\begin{array}{l}\text { Oxyaquic } \\
\text { Dystrudepts }\end{array}$ & $\begin{array}{l}\text { Loamy- } \\
\text { skeletal }\end{array}$ & Frigid \\
\hline East & Ridge & FS04WV101001 & Typic Hapludults & Fine-loamy & Frigid \\
\hline East & Shoulder & FS04WV067007 & Typic Dystrudepts & $\begin{array}{l}\text { Coarse- } \\
\text { loamy }\end{array}$ & Frigid \\
\hline West & Back slope & FS04WV067001 & Fragic Dystrudepts & $\begin{array}{l}\text { Loamy- } \\
\text { skeletal }\end{array}$ & Mesic \\
\hline West & Ridge & FS04WV067002 & Typic Dystrudepts & $\begin{array}{l}\text { Loamy- } \\
\text { skeletal }\end{array}$ & Mesic \\
\hline West & Ridge & FS04WV067003 & Typic Dystrudepts & $\begin{array}{l}\text { Coarse- } \\
\text { loamy }\end{array}$ & Mesic \\
\hline West & Floodplain & FS04WV067004 & $\begin{array}{l}\text { Fluventic } \\
\text { Dystrudepts }\end{array}$ & $\begin{array}{l}\text { Loamy- } \\
\text { skeletal }\end{array}$ & Mesic \\
\hline West & Bench & FS04WV067005 & Typic Fragiudepts & $\begin{array}{l}\text { Loamy- } \\
\text { skeletal }\end{array}$ & Mesic \\
\hline West & Foot slope & FS04WV067006 & Aquic Dystrudepts & $\begin{array}{l}\text { Loamy- } \\
\text { skeletal }\end{array}$ & Mesic \\
\hline West & Shoulder & FS04WV067017 & Typic Dystrudepts & $\begin{array}{l}\text { Coarse- } \\
\text { loamy }\end{array}$ & Mesic \\
\hline
\end{tabular}




\title{
Chapter 5. \\ Acid Risk Assessment and Management Implications
}

\begin{abstract}
Acid Risk Assessment
The Ca:Al molar ratio of the soil solution can be used as an indicator of forest damage from aluminum stress. Ca:Al molar ratio of 1.0 results in a $50 \%$ risk of adverse impacts on forest; a $\mathrm{Ca}$ :Al molar ratio of 0.5 to 0.6 causes a $75 \%$ risk of adverse impacts on forest; a $\mathrm{Ca}$ :Al molar ratio of 0.2 gives a $95 \%$ or greater risk of adverse impacts on forest. But a ratio of 0.2 plus a BSECEC of less than $15 \%$ equates to a $100 \%$ risk of adverse forest impacts (Cronan and Grigal, 1995). These threshold values were set using tree seedling growth and mortality. Thus, this risk is interpreted to be a risk for regeneration failures thus causing forest productivity decline.

The values set by Cronan and Grigal (1995) were based on soil solution sampling. However, the calcium and aluminum data obtained from $\mathrm{SrCl}_{2}$ extraction method (Joslin and Wolfe, 1989) performed by The Pennsylvania State University Agricultural Analytical Laboratory was used for the assessment because it approximates the values obtained from soil water samples. This extraction method is thought to extract only the "plant available" calcium and aluminum. The BSECEC used in the assessment came from the extractions performed by the University of Maine.

Risk for the soils of the Cherry River watershed was set according to the thresholds shown in Table 5.1.
\end{abstract}


Table 5.1. Thresholds used for risk assessment in the Cherry River watershed.

\begin{tabular}{lcc}
\hline Risk & Ca:Al Molar Ratio & BSECEC \\
\hline $\mathbf{0} \%$ & $3.0+$ & -- \\
$>\mathbf{5 0} \%$ & $1.1-2.9$ & -- \\
$\mathbf{5 0} \%$ & $0.7-1.0$ & -- \\
$\mathbf{7 5} \%$ & $0.5-0.6$ & -- \\
$\mathbf{7 7 5} \%$ & $0.3-0.4$ & $<15.0$ \\
$\mathbf{1 0 0 \%}$ & $0.0-0.2$ & $<15.0$ \\
\hline
\end{tabular}

\section{East versus West Areas}

When the soil profiles from the east and west project areas were compared, the acid risks were similar. The risks for the transition and upper B horizons were 50\% (Table 5.2). However, the lower B and BC horizons in the east area were at a higher risk than the west. Only the A and C horizons of both areas did not suggest risk to forest productivity. Risk increased initially for the upper horizons through the upper B with depth. This trend was predicted by the decrease in organic matter with depth discussed in Chapter 3.

Table 5.2. The soil acidification parameters used for the acid risk assessment of the soils in Cherry River watershed for the east and west project areas by horizon.

\begin{tabular}{llccc}
\hline Area & Horizon & Ca:Al Molar Ratio & $\begin{array}{c}\text { BSECEC } \\
\text { \% }\end{array}$ & $\begin{array}{c}\text { Risk } \\
\mathbf{\%}\end{array}$ \\
\hline East & A & 1.4 & 12.9 & $<50$ \\
West & A & 2.0 & 15.1 & $<50$ \\
\hline East & Transition & 0.6 & 5.9 & 50 \\
West & Transition & 0.6 & 7.9 & 50 \\
\hline East & Upper B & 0.3 & 6.0 & $>75$ \\
West & Upper B & 0.3 & 7.0 & $>75$ \\
\hline East & Lower B & 0.3 & 5.5 & $>75$ \\
West & Lower B & 0.8 & 7.2 & 50 \\
\hline East & BC & 0.5 & 7.3 & 75 \\
West & BC & 3.8 & 9.9 & 0 \\
\hline East & C & -- & -- & -- \\
West & C & 6.9 & 28.6 & 0 \\
\hline
\end{tabular}


Although both project areas were underlain by Pottsville geology, the formations were slightly different. The parent material in the west project area (primarily New River Formation) has a higher base status than the parent material in the east area (primarily Kanawha Formation) (Price, 1939). There were significant differences in BSECEC between the two project areas in more than one horizon which indicated that the degree of acidification between the two areas was different (Chapter 3). The east project area had a higher percentage of risk as well as significantly higher aluminum content and lower BSECEC than the west area.

\section{Landscape Position}

The shoulder positions have a $100 \%$ risk in both areas (Table 5.3). The ridge and floodplain horizons have a $75 \%$ risk in both areas. The back slope and bench positions have a $100 \%$ risk in the west area and only a $>75 \%$ risk in the east area. The foot slopes have a $75 \%$ risk in the east area and a $>75 \%$ risk in the west area.

Table 5.3. Risk to forest productivity by landscape position based on Ca:Al molar ratios and \% BSECEC in the upper $B$ horizon.

\begin{tabular}{llccc}
\hline Area & $\begin{array}{l}\text { Landscape } \\
\text { position }\end{array}$ & $\begin{array}{c}\text { Ca:Al } \\
\text { Molar Ratio }\end{array}$ & $\begin{array}{c}\text { BSECEC } \\
\text { \% }\end{array}$ & $\begin{array}{c}\text { Risk } \\
\text { \% }\end{array}$ \\
\hline East & Ridge & 0.4 & 9.1 & $>75$ \\
& Shoulder & 0.2 & 6.4 & 100 \\
& Back slope & 0.3 & 7.2 & $>75$ \\
& Bench & 0.3 & 6.9 & $>75$ \\
& Foot slope & 0.6 & 6.8 & 75 \\
& Floodplain & 0.5 & 12.7 & 75 \\
\hline \multirow{2}{*}{ West } & Ridge & 0.5 & 8.6 & 75 \\
& Shoulder & 0.2 & 6.9 & 100 \\
& Back slope & 0.2 & 9.1 & 100 \\
& Bench & 0.2 & 11.4 & 100 \\
& Foot slope & 0.4 & 10.9 & $>75$ \\
& Floodplain & 0.3 & 19.6 & $>75$ \\
\hline
\end{tabular}


When these landscape positions are further separated into parent material categories, more trends can be seen. The BSECEC decreased with depth in the residual soils (mostly ridge and shoulder) for both project areas (Tables 3.5 and 3.9) as did the Ca:Al molar ratio. Most of these soils were mapped as Mandy and Gilpin mapping units.

The colluvial soils (most back slope and bench, and all foot slope) did not show a consistent trend in $\mathrm{Ca}: \mathrm{Al}$ molar ratios and BSECEC (Tables 3.5 and 3.9), presumably because of the mixed parent materials involved. This mixing of materials in colluvium during down slope movement gives a less defined character of weathering material. These soils were predominantly mapped as Snowdog and Buchanan mapping units.

The alluvial soils (floodplain) in both project areas were very bouldery and were present in small drainages. These soils were also included in the Snowdog and Buchanan mapping units. They had water tables present within the upper $1.5 \mathrm{~m}$ (60 in) of the profile, and therefore, remained saturated throughout much of the year. Both the $\mathrm{Ca}: \mathrm{Al}$ molar ratio and the BSECEC were above 3.0 and 15, respectively, near the surface and decreased through the $\mathrm{A}$ and $\mathrm{B}$ horizons, then they increased to similar values in the $\mathrm{BC}$ and $\mathrm{C}$ horizons (Tables 3.5 and 3.9). These soils contained buried horizons, which had elevated organic matter and base cations in the lower portions of the soil profiles.

\section{Risk by Soil Pit}

The percentage of risk by soil pits shows that the east area has a slightly higher level of acidification than the west area (Figure 5.1; Table 5.4). The percentage of pits at some level of risk in the east area is $92 \%$, while the west area has $86 \%$. The degree of risk between the two areas differs as well, with $72 \%$ of pits in the east area having greater than $75 \%$ risk compared to $55 \%$ of the west area pits having the same risk. However, the 
percentages of pits with a $75 \%$ or greater risk were similar for the two areas, $81 \%$ for the east area and $79 \%$ for the west area.

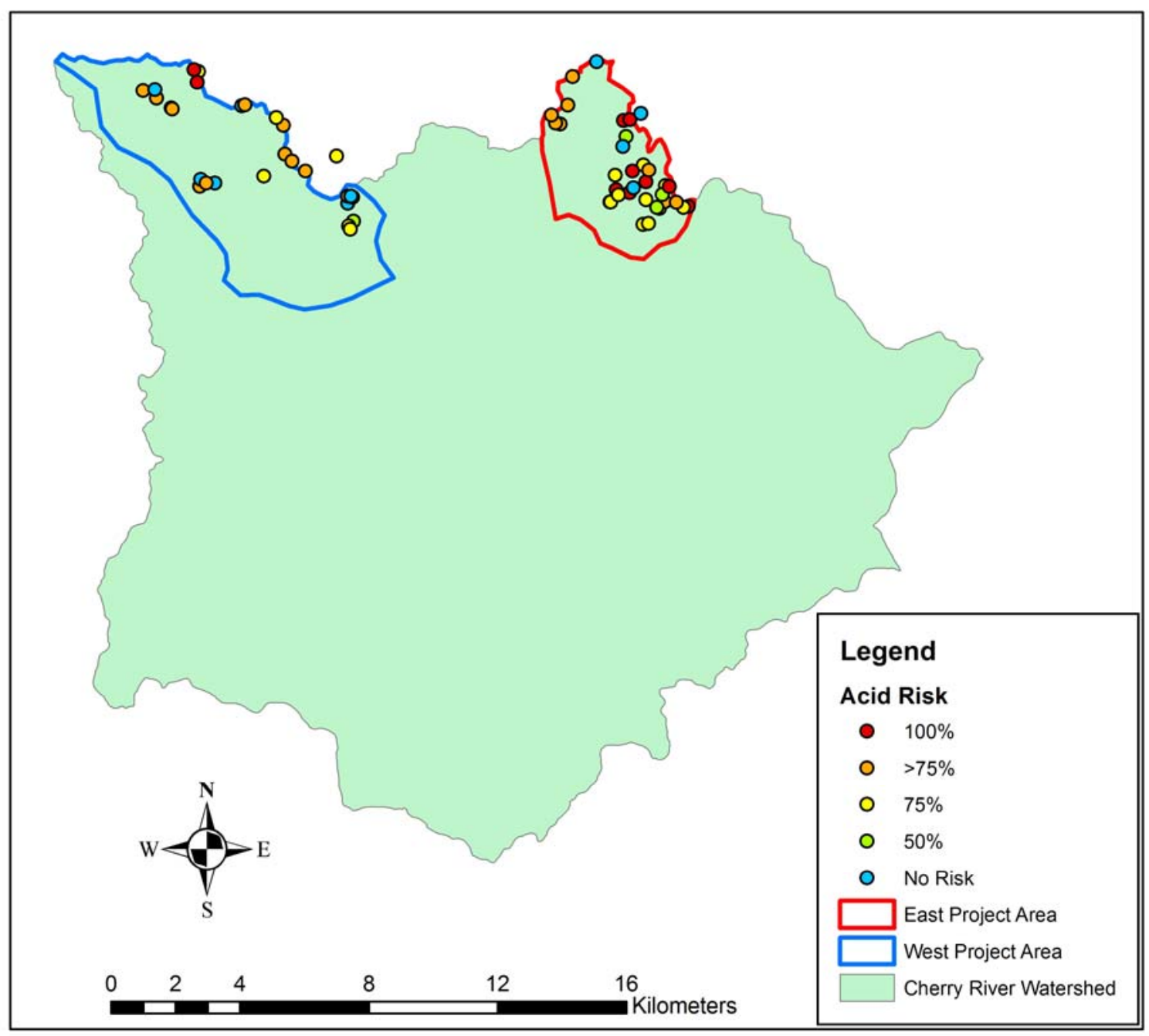

Figure 5.1. Acid risk by soil sampling location. Acid risk was based on the upper B horizon in the soil pit.

Table 5.4. The percentage of soil pits for each level of risk in each project area. Risk assessment was based on upper $B$ horizon data.

\begin{tabular}{lcc}
\hline & $\begin{array}{c}\text { East Area Pits } \\
\text { \% }\end{array}$ & $\begin{array}{c}\text { West Area Pits } \\
\text { \% }\end{array}$ \\
\hline No risk & 8 & 14 \\
$\mathbf{5 0 \%}$ risk & 11 & 7 \\
$\mathbf{7 5 \%}$ risk & 8 & 24 \\
$\mathbf{7 5 \%}$ risk & 53 & 45 \\
$\mathbf{1 0 0 \%}$ risk & 19 & 10 \\
\hline
\end{tabular}




\section{Management Implications}

This risk assessment of the soils in the watershed can lead to management implications. For example, timber harvesting practices can be modified to take into account areas with low $\mathrm{Ca}: \mathrm{Al}$ molar ratios. Harvest methods affect the nutrient cycling of the forest floor differently (Elliott and Knoepp, 2005). Methods, such as whole-tree harvesting, that remove excess organic material have more detrimental effects on nutrient availability than methods, stem-only, that leave organic material (branches, leaves, tree crowns) at the harvest site (Elliott and Knoepp, 2005). Short harvest rotations also have shown decreases in soil base cations due to the lower accumulation of organic matter and higher soil disturbance (Grigal, 2000). Likewise, soil disturbing activities, including skidding and log yarding, decrease soil productivity by removing soil organic matter and compacting the soil (Berger et al., 2004). Thus, the Ca:Al molar ratio can be used to guide the placement of soil disturbing activities and determine harvest method and rotation length.

The majority of tree roots occur within $90 \mathrm{~cm}$ of the surface of the soil with feeder roots in the upper $60 \mathrm{~cm}$ (McDaniel, 1997; Oettinger, 2005). The upper B horizons of the soils sampled in Cherry River watershed were above $60 \mathrm{~cm}$ in the zone of the feeder roots. The upper B horizon chemistry also has been correlated most strongly with foliar chemistry in sugar maple (Bailey et al., 2004). Therefore, the upper B horizon data were used for making management recommendations.

Both project areas had similar Ca:Al molar ratios and BSECEC in the upper B horizons. Therefore, the management recommendations for the areas are the same. 
Because the majority of the base cations in the watershed come from litter fall, soil disturbance should be limited as much as reasonably possible.

Methods for harvesting also should leave woody debris and slash material on site to augment nutrient and organic matter input (Mann et al., 1988). Whole-tree harvesting should be avoided, and instead stem-only or sawlog harvesting should be used. The most effective way to preserve organic matter on the soil surface is by helicopter or skyline logging. On average, helicopter and skyline logging disturb only $2.5 \%$ of a site compared to $\geq 10 \%$ for more conventional harvest methods (Grigal, 2000).

The rotation of harvest for these areas should be extended in order for the base cations in the soil to be replenished (Blanco et al., 2005). Longer rotations have the higher percentages of base cation return (Blanco et al., 2005). Because the Cherry River watershed soils have low antecedent base cation concentrations, the longest reasonable rotation should be used.

Soil disturbance should be prohibited or limited on landscape positions that have higher Ca:Al molar ratios. For positions with low $\mathrm{Ca}: \mathrm{Al}$ ratios such as the shoulder positions for both project areas and the bench and back slope positions in the west area, the mitigation costs for forest productivity would be high. Because forest productivity is at the highest risk on these positions, they would be the best places to place skid roads and log landings. Further disturbing these areas would have the least effect on productivity. The positions with lower risk should have better potential for vegetative growth, and therefore, the soil should not be disturbed (Mann et al., 1998; Grigal, 2000). Management recommendations cannot be made based on the site specific risk assessment due to the variability of the soils. Although there is a large number of soil 
pits in the watershed, the density of sampling does not show the risk to forest productivity at a sufficient level to make project level decisions. For making this type of decision, more soil samples would need to be taken within the project boundaries with a higher sample density. In general, areas that show a high density of samples with low or no risk should not have soil disturbance and should be harvested by methods like helicopter or sky-line logging. Also, areas with a high density of samples at high risk would be optimum for placement of skid roads and log landings.

One possible mitigation for these high risk areas is liming. There have been several research projects focusing on the liming of forest soils. However, the results from these studies have been mixed and many could not be replicated (Rengel, 2003). If liming is used for mitigation, there are considerations that should be taken into account. Pelletized lime and limestone sands are the only products that can currently be used in ground spreading equipment (Mizel, 2005). The liming materials that have worked the best in the studies have been dolomitic limestone (Rengel, 2003) and coarse limestone sands have been found to be more cost efficient than pelletized lime (Mizel, 2005). Detrimental effects of liming forest soils have been noted in these studies as well. Liming has been seen to cause the leaching of organic carbon and nitrogen from the soil due to increased microbial activity (Rengel, 2003). Therefore, liming is a possible mitigation for these high risk soils; however, due to the associated unknowns more research is needed. 


\section{Conclusions}

The majority of soils in the Cherry River watershed showed some level of forest productivity risk. East area soils were at a higher degree of risk than the west area soils. Ridge and shoulder soils (residual soils) showed fewer signs of base cation input than the colluvial and alluvial soils. Soils showing the highest risk to forest productivity were these located on the shoulders. These soils also had a very low pool of base cations in the soil profile. Soils on the ridge and shoulder positions were mapped as Mandy in the east and Gilpin in the west; these mapping units were at the highest risk to forest productivity. The Snowdog and Buchanan soils were mapped on the majority of the rest of the areas, including the floodplain locations. The floodplain soils showed the lowest risk to forest productivity and the highest amount of base cations.

The results of this study indicate these soils have a high risk for future regeneration of marketable timber. With harvesting and organic matter removal, base cations are removed from the system causing these soils to become more acidified. This additional acidification raises the risk of regeneration failure. Therefore, the forest potentially will not regenerate a valuable timber stand to replace the one that was removed. 


\section{Chapter 6. \\ Bibliography}

Adams, Mary B. 1999. Acidic deposition and sustainable forest management in the central Appalachians, USA, Forest Ecology and Management 122(1-2): 17-28.

Adams, Mary B. and J.N. Kochenderfer. 1998. The Fernow Whole-watershed Acidification Study: Soil Chemistry. In "The Effects of Acid Deposition on Pennsylvania's Forests." (W.E. Sharpe and J.R. Drohan, eds.) Proceedings of the 1998 PA Acidic Deposition Conference, Vol. 1. Environmental Resources Research Institute, University Park, PA.

Adams, M.B., J.A. Burger, A.B. Jenkins, and L. Zelazny. 2000. Impact of harvesting and atmospheric pollution on nutrient depletion of eastern U.S. hardwood forests. Forest Ecology and Management 138:301-319.

Bache, B.W. 1986. Aluminum mobilization in soils and waters. Journal of the Geologic Society, London 143:699-706.

Bailey, S.W., S.B. Horsley, and R.P. Long. 2005. Thirty years of change in forest soils of the Allegheny Plateau, Pennsylvania. Soil Sci. Soc. Am. J. In Process.

Bailey, S.W., S.B. Horsley, R.P. Long, and R.A. Hallett. 2004. Influence of edaphic factors on Sugar Maple nutrition and health on the Allegheny Plateau. Soil Sci. Soc. Am. J. 68:243-252.

Berger, A.L., K.J. Puettmann, and G.E. Host. 2004. Harvesting impacts on soil and understory vegetation: the influence of season of harvest and within-site disturbance patterns on clear-cut aspen stands in Minnesota. Can. J. For.Res. 34:2159-2168.

Binkley, D., C.T. Driscoll, H.L. Allen, P. Schoeneberger, and D. McAvory. 1989. Acidic deposition and forest soils: Context and case studies in the southeastern United States. Springer-Verlag, New York.

Blake, L, K.W.T Goulding, C.J.B. Mott, and A.E. Johnston. 1999. Changes in soil chemistry accompanying acidification over more than 100 years under woodland and grass at Rothamsted Experimental Station, UK. European J. of Soil Science 50:401-412.

Blanco, J.A., M.A. Zavala, J.B. Imbert, and F.J. Castillo. 2005. Sustainability of forest management practices: evaluation through a simulation model of nutrient cycling. Forest Ecology and Management 213:209-228.

Brady, N.C. and R.R. Weil. 2002. The nature and properties of soils, $3^{\text {rd }}$ ed. Prentice Hall, New Jersey. 
Clean Air Status and Trends Network (CASNET). (2005). Environmental Protection Agency. $<$ http://www.epa.gov/castnet/>.

Connolly, S.J., T.C. Cain, J.S. Vestal, and P.J. Edwards. 2004. The potential effects of acid deposition: What is a national forest to do? Proceedings of Advancing the Fundamental Sciences Conference. San Diego, CA. In Process.

Cronan, C.S., and D.F. Grigal. 1995. Use of Calcium/Aluminum ratios as indicators of stress in forest ecosystems. J. Environ. Qual. 24:209-226.

Danehy, R.J., C.G. Colson, K.B. Parrett, and S.D. Duke. 2005. Patterns and sources of thermal heterogeneity in small mountain streams within a forested setting. Forest Ecology and Management 208:287-302.

Demchik, M.C. and Sharpe, W.E. 1999. Foliar and root chemistry response of hayscented fern to liming and fertilization. Northern J. Appl. For. 16(1):33-35.

DeWalle, D.R., B.R. Swistock, R.G. Sayre, and W.E. Sharpe. 1991. Spatial variations of sapwood chemistry with soil acidity in Appalachian forests. J. Environ. Qual. 20:486-491.

DeWalle, D.R., J.S. Tepp, B.R. Swistock, W.E. Sharpe, and P.J. Edwards. 1999. Treering cation response to experimental watershed acidification in West Virginia and Maine. J. Environ. Qual. 28:299-309.

Driscoll, C.T., G.B. Lawrence, A.J. Bulger, T.J. Butler, C.S. Cronan, C. Eagar, K.F. Lambert, G.E. Likens, J.L. Stoddard, and K.C. Weathers. 2001. Acidic deposition in the northeastern United States: Sources and inputs, ecosystem effects, and management strategies. BioScience 51(3):180-198.

Drohan, J.R. and W.E. Sharpe. 1997. Long-term changes in forest soil acidity in Pennsylvania, U.S.A. Water, Air, and Soil Pollution 95:299-311.

Duchesne, L., R. Ouimet, and C. Morneau. 2003. Assessment of Sugar Maple health based on basal area growth pattern. Can. J. For. Res. 33:2074-2080.

Elliott, K.J. and J.D. Knoepp. 2005. The effects of three regeneration harvest methods on plant diversity and soil characteristics in the southern Appalachians. Forest Ecology and Management 211:296-317.

EPA (U.S. Environmental Protection Agency). 1998. National air quality and emissions trends report. EPA 454/R-00-003.

Federer, C.A., J.W. Hornbeck, L.M. Tritton, C.W. Martin, R.S. Pierce, and C.T. Smith. 1989. Long-term depletion of calcium and other nutrients in Eastern US forests. Environmental Management 13(5):593-601. 
Fernandez, I.J., L.E. Rustad, S.A. Norton, J.S. Kahl, and B.J. Cosby. 2003. Experimental acidification causes soil base-cation depletion at the Bear Brook watershed in Maine. Soil Sci. Soc. Am. J. 69:1909-1919.

Gbondo-Tugbawa, S.S., and C.T. Driscoll. 2003. Factors controlling long-term changes in soil pools of exchangeable basic cations and stream acid neutralizing capacity in a northern hardwood forest ecosystem. Biogeochemistry 63:161-185.

Grigal, D.F. 2000. Effects of extensive forest management on soil productivity. Forest Ecology and Management 138:167-185.

Grimm, J.W., and J.A. Lynch. 2004. Enhanced wet deposition estimates using modeled precipitation inputs. Environmental Monitoring and Assessment 90:243-268.

Grossman, R.B, D.S. Harms, D.F. Kingsbury, R.K. Shaw, and A.B. Jenkins. 2001. Assessment of soil organic carbon using the U.S. soil survey. p. 87 - 104. In Lal et al. (ed) Assessment Methods for Soil Carbon. Lewis Publishers, Boca Raton, Florida.

Holmberg, M., J. Mulder, M. Posch, M. Starr, M. Forsius, M. Johansson, J. Bak, H. Ilvesniemi, and H. Sverdrup. 2001. Critical Loads of Acidity for Forest Soils: Tentative Modifications. Water, Air, and Soil Pollution: Focus 1:91-101.

Huntington, T.G. 2000. The potential for calcium depletion in forest ecosystems of southeastern United States: review and analysis. Global Biogeochemical Cycles 14(2):623-638.

Huntington, T.G., R.P. Hooper, C.E. Johnson, B.T. Aulenbach, R. Cappellato, and A.E. Blum. 2000. Calcium depletion in a southeastern United States forest ecosystem. Soil Sci. Soc. Am. J. 64:1845-1858.

Jandl, R., C. Alewell, and J. Prietzel. 2004. Calcium loss in central European forest soils. Soil Sci. Soc. Am. J. 68:588-595.

Jenkins, A.B. (2002). Organic carbon and fertility of forest soils on the Allegheny Plateau of West Virginia, West Virginia University, [On-line Abstract]. Available: https://etd.wvu.edu/etd/etdDocumentData.jsp?jsp_etdId=2486

Johnson, C.E. 2002. Cation exchange properties of acid forest soils of the northeastern USA. European Journal of Soil Science 53:271-282.

Johnson, D.W., and D.E. Todd. 1990. Nutrient cycling in forests of Walker Branch watershed, Tennessee: roles of uptake and leaching in causing soil changes. J. Environ. Qual. 19:97-104. 
Joslin, J.D., J.M. Kelly, and H. Van Miegroet. 1992. Soil chemistry and nutrition of North American spruce-fir stands: evidence for recent change. J. Environ. Qual. 21:12-30.

Joslin, J.D. and M.H. Wolfe. 1989. Aluminum effects on Northern Red Oak seedling growth in six forest soil horizons. Soil Sci Soc. Am. J. 53: 274-281.

Lawrence, G.B., M.B. David, G.M. Lovett, P.S. Murdoch, D.A. Burns, J.L. Stoddard, B.P. Baldigo, J.H. Porter, and A.W. Thompson. 1999. Soil calcium status and the response of stream chemistry to changing acidic deposition rates. Ecological Applications 9(3):1059-1072.

Logsdon, S.D. and C.A. Cambardella. 2000. Temporal Changes in Small DepthIncremental Soil Bulk Density. Soil Sci. Soc. Am. J. 64: 710-714.

Lyon, J., and W.E. Sharpe. 1999. An assessment of the Ca:Al ratios of selected Pennsylvania forest soils. Water, Air, and Soil Pollution 109:53-65.

Mann, L.K., D.W. Johnson. D.C. West, D.W. Cole, J.W. Hornbeck, C.W. Martin, H. Riekerk, C.T. Smith, W.T. Swank, L.M. Tritton, and D.H. Van Lear. (1988). Effects of whole-tree and stem-only clearcutting on postharvest hydrologic losses, nutrient capital, and regrowth. Forest Science 34:412-428.

Markewitz, D., D.D. Richter, H.L. Allen, and J.B. Urrego. 1998. Three decades of observed soil acidification in the Calhoun Experimental Forest: Has acid rain made a difference? Soil Sci. Soc. Am. J. 62:1428-1439.

McDaniel, A. 1997. Tree roots - where are they? The Virginia Gardener Newsletter 6(8).

Miller, J.O., J.M. Galbraith, and W.L. Daniels. 2004. Soil organic carbon content in frigid southern Appalachian mountain soils. Soil Sci. Soc. Am. J. 68:194-203.

Mizel, N. 2005.The transport and fate of applied limestone sand and palletized lime following timber harvesting. Master's Thesis, The Pennsylvania State University. $64 \mathrm{p}$.

Mount, H. R., and R.F. Paetzold. 2002. The temperature regime for selected soils in the United States. United States Department of Agriculture, Natural Resources Conservation Service, National Soil Survey Center, Lincoln, Nebraska, Soil Survey Investigation Report No. 48.

National Atmospheric Deposition Program (NADP). 2005. National Atmospheric Deposition Program. $<$ http://nadp.sws.uiuc.edu/>.

National Atmospheric Deposition Program (NADP-NRSP-3). 2005. NADP Program Office, Illinois State Water Survey, 2204 Griffith Dr., Champaign, IL 61820. 
Oettinger, D. 2005. Planting under trees: protecting tree roots from damage is important when creating beds under trees. Landscape Architecture April:56-68.

Pelle. E. 1990. Elemental organic analysis. Part 1. Am. Lab. 22:116-125.

Prescott, C.E. 2002. The influence of the forest canopy on nutrient cycling. Tree Physiology 22(15/16):1193-1200.

Price, P.H.. West Virginia Geologic Survey: Greenbrier County. Wheeling News Litho. Co.: Wheeling, WV. 1939.

Reger, D.B. West Virginia Geologic Survey: Nicholas County. Wheeling News Litho. Co.: Wheeling, WV. 1921.

Reger, D.B. West Virginia Geologic Survey: Webster County and Portion of Mingo District, Randolph County, South of Valley Fork of the Elk River. Wheeling News Litho. Co.: Wheeling, WV. 1920.

Rengel, Z. (ed). 2003. Handbook of Soil Acidity. Marcel Dekker, Inc.: New York.

Rice, C.L., R.L. Martino, and E.R. Slucher. 1992. Regional aspects of Pottsville and Allegheny stratigraphy and depositional environments; Ohio and Kentucky. U. S. Geological Survey: Reston, VA. No.OF 92-0558.

Schnably, Jamie .2003.. Soil characterization, classification, and ciomass accumulation in the Otter Creek Wilderness. Master's Thesis, West Virginia University, [On-line Abstract]. Available: https://etd.wvu.edu/etd/etdDocumentData.jsp?jsp_etdId=3215

Singer, C.E., and D. C. Havill. 1985. Manganese as an ecological factor in salt marshes, Plant Ecology 62(1-3):287-292.

Skinner, M.F., D. Zabowski, R. Harrison, A. Lowe, and D. Xue. 2001. Measuring the cation exchange capacity of forest soils. Commun. Soil Sci. Plant Anal. 32(1112):1751-1764.

Skyllberg U. 1999. $\mathrm{pH}$ and solubility of aluminum in acidic forest soils: a consequence of reactions between organic acidity and aluminum alkalinity. European Journal of Soil Science 50:95-106.

Soil Survey Staff. 2003. Keys to Soil Taxonomy. $9^{\text {th }}$ ed. National Cooperative Soil Survey. U.S. Government Printing Office, Washington, D.C.

Soil Survey Staff, 1996. Soil Laboratory Methods Manual. Soil Survey Investigations Report No. 42. Version 3.0. USDA Natural Resources Conservation Service. National Soil Survey Center. Lincoln, Nebraska 
Soil Survey Staff. 2002. Soil Survey of Greenbrier County, West Virginia. National Cooperative Soil Survey. U.S. Government Printing Office, Washington, D.C.

Soil Survey Staff. 1992. Soil Survey of Nicholas County, West Virginia. National Cooperative Soil Survey. U.S. Government Printing Office, Washington, D.C.

Soil Survey Staff. 1998. Soil Survey of Webster, West Virginia. National Cooperative Soil Survey. U.S. Government Printing Office, Washington, D.C.

Soil Survey Staff. 1975. Soil Taxonomy. A basic system of soil classification for making and interpreting soil surveys. USDA - Soil Conservation Service Agricultural Handbook \#436, U.S. Gov. Print. Office, Washington, DC, 754 p.

Sparks, D.L. 2003. Environmental Soil Chemistry. $2^{\text {nd }}$ ed. Academic Press, San Diego.

Strausbaugh, P.D. and E.L. Core. 1977. Flora of West Virginia. $2^{\text {nd }}$ Ed. Seneca Books, Inc, Grantsville, WV.

Thomas, G.W. 1982. Exchangeable cations. In: A.L. Page (ed.) Methods of soil analysis, Part 2 Chemical and microbiological properties, 2nd edition. Agronomy 9: 159165.

Tracy, L. 2005. MNF Geologist, personal communication.

U.S. Geological Survey. 1999. Soil-calcium depletion linked to acid rain and forest growth in the eastern United States. USGS 98-4267.

Washburn, C.S. and M. Arthur. 2002. Spatial variability in soil nutrient availability in an oak-pine forest: potential effects of tree species. Canadian Journal of Forest Research 33(12):2321-2330.

Yanai, R.D., R.P. Phillips, M.A. Arthur, T.G. Siccama, and E.N. Hane. 2005. Spatial and temporal variation in calcium and aluminum in northern hardwood forest floors. Water, Air, and Soil Pollution 160:109-118.

Yang, Z.H., B.R. Singh, and B.K Sitaula. 2004. Soil organic carbon fractions under different land uses in Mardi watershed of Nepal. Commun. Soil Sci. Plant Anal. 35(5-6):615-629. 


\section{Appendices \\ APPENDIX A \\ SOIL DECRIPTION GUIDLINES}

The following list of physical and morphological features, as outlined in the Soil Survey Manual (Soil Survey Staff, 1993) will be noted when describing field soil properties:

1. The presence of horizons or layers

2. Depth and thickness of each horizon (in, $\mathrm{cm}$ )

3. Boundary of each horizon (Distinction and Topography)

4. Matrix color (Hue, value, and chroma as represented by the Munsell Soil Color notations)

5. Pockets of dissimilar material (Abundance, contrast, size, and color)

6. Mottling (Abundance, contrast, size, and color)

7. Texture class by feel (\% sand silt, and clay)

8. Structure (Type, strength, and grade)

9. Consistence

10. Field $\mathrm{pH}$ of each horizon

11. Roots (Size and abundance)

12. Presence of artifacts

13. Presence of rock fragments for each horizon (Size and type)

14. Other field observations may include the presence of clay films, redoximorphic features, and bridged voids.

15. Slope; the presence of rills, gulleys, and compacted zones will also be noted.

16. Dominant overstory, midstory, and ground vegetation within 1 meter area surrounding the soil pit. 


\title{
APPENDIX B FULL CHARACTERIZATION PROFILE DESCRIPTIONS
}

\author{
Profile Number: 1
}

Soil Description Number: FS04WV025001

Sample Date: June 30, 2004

Soil Family: Typic Dystrudepts

Area: Summit Lake Rec. Area FS rd.77

Location: (GPS) NAD27 38 $15.167 \mathrm{~N} 80^{\circ} 25.639 \mathrm{~W}$

EPE 62ft

$17550108 \mathrm{E} 4233811 \mathrm{~N}$

Natural Vegetation: Black cherry, red maple, striped maple, beech, birch, hemlock

Soil Temp. Regime: frigid

Parent Material: Pottsville sandstone/ gray shale, colluvium

Physiography: Allegheny Plateau (back slope)

Relief: concave

Drainage: well-drained

Elevation: $1092 \mathrm{~m}(3580 \mathrm{ft})$

Slope: $23 \%$

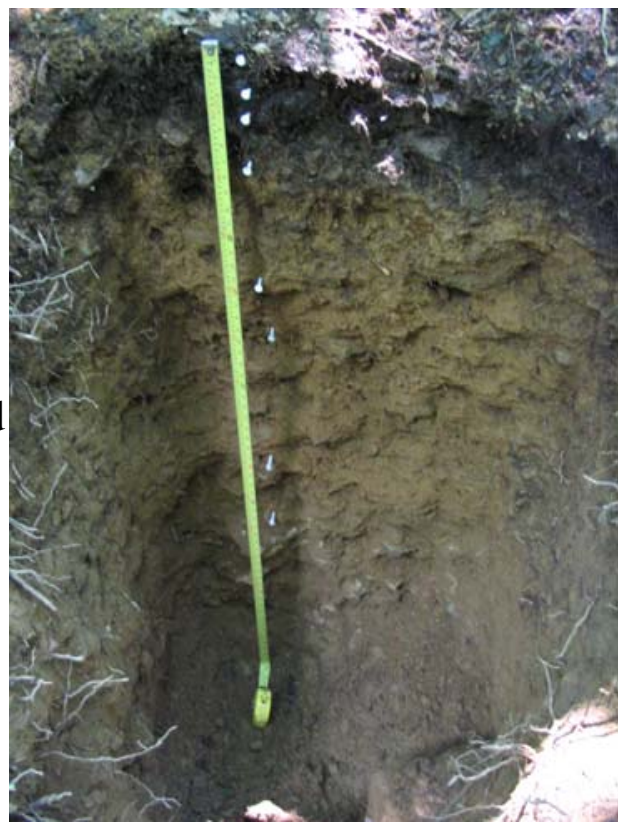

Aspect: NW

Surface stoniness: $<0.01 \%$

Site: FS04WV025001 described and sampled by Stephanie Connolly and Cara Sponaugle

Oi -- 2.5 to $0 \mathrm{~cm}$ ( 1 to 0 in)

Oe -- 0 to $2.5 \mathrm{~cm}$ ( 0 to $1 \mathrm{in})$

A1 -- 2.5 to $7.5 \mathrm{~cm}$ (1 to 3 in); very dark brown (10YR 2/2) channery loam; moderate very fine and fine granular structure; very friable; many very fine and fine roots; $25 \%$ channers; clear wavy boundary.

A2 -- 7.5 to $12.5 \mathrm{~cm}$ (3 to 5 in); dark grayish brown (10YR 4/2) channery loam; moderate very fine and fine granular structure; very friable; many very fine and fine and common medium roots; $25 \%$ channers; clear wavy boundary.

AB -- 12.5 to $20 \mathrm{~cm}$ (5 to 8 in); very dark grayish brown (10YR 3/2) channery loam; weak medium subangular blocky and moderate medium granular structure; friable; few fine and common medium roots; $15 \%$ channers; clear wavy boundary.

Bw1 -- 20 to $40.5 \mathrm{~cm}$ (8 to 16 in); yellowish brown (10YR 5/8) channery clay loam; moderate medium subangular blocky structure; friable; few fine and common medium roots; common faint clay films on rock and ped faces; $25 \%$ channers; clear wavy boundary.

Bw2 -- 40.5 to $58.5 \mathrm{~cm}$ (16 to 23 in); dark yellowish brown (10YR 4/6) channery clay loam; moderate medium subangular blocky structure; friable; few fine and common medium roots; common faint clay films on rock and ped faces; $25 \%$ channers; clear wavy boundary. 
2Bw3 -- 58.5 to $89 \mathrm{~cm}$ (23 to 35 in); dark yellowish brown (10YR 4/6) very channery loam; weak medium subangular blocky structure; friable; few fine roots; $40 \%$ channers; clear wavy boundary.

2Bw4 -- 89 to $109 \mathrm{~cm}$ (35 to 43 in); dark yellowish brown (10YR 4/4) very channery sandy loam; weak medium subangular blocky structure; friable; few fine roots; $40 \%$ channers; clear wavy boundary.

2BC -- 109 to $152.5+\mathrm{cm}$ (43 to $60+$ in); dark yellowish brown (10YR 4/4) extremely channery sandy loam; weak fine subangular blocky structure; loose; few fine roots matted around rock fragments; $65 \%$ channers.

Notes: This site is located down slope west of FS road 77 towards Coats Run. The understory contains heavily browsed remnants of trillium, cucumber root, and greenbrier. There is an increase in sand at the discontinuity. Rounded stones were found in the Bt1 as well as a large boulder in the $\mathrm{BC}$ horizon. There was no fragipan or dense layer found. 
Profile Number: 2

Soil Description Number: FS04WV025002

Sample Date: August 20, 2004

Soil Family: Typic Dystrudepts

Area: Summit Lake Rec. Area

Location: (GPS) NAD83 38 $15.501 \mathrm{~N} 80^{\circ} 26.046 \mathrm{~W}$

EPE $33 \mathrm{ft}$

Natural Vegetation: Black cherry, sugar maple, yellow poplar

Soil Temp. Regime: frigid

Parent Material: Pottsville gray shale, residuum

Physiography: Allegheny Plateau (Back slope)

Relief: concave

Drainage: well-drained

Elevation: $1056 \mathrm{~m}(3465 \mathrm{ft})$

Slope: $27 \%$

Aspect: ESE

Surface stoniness: $0.01 \%$

Site: FS04WV025002 described and sampled by Stephanie Connolly

$\mathbf{O}--5$ to $0 \mathrm{~cm}$ (2 to 0 in).

A -- 0 to $5 \mathrm{~cm}$ (0 to 2 in); dark brown (10YR 3/3) channery loam; moderate very fine and fine granular structure; very friable; many very fine to medium and few coarse roots; $20 \%$ rock fragments (10\% channers, $10 \%$ gravels); clear smooth boundary.

AB -- 5 to $7.5 \mathrm{~cm}$ (2 to 3 in); dark yellowish brown (10YR 4/4) channery loam; weak fine granular and moderate fine and weak medium subangular blocky structure; friable; many fine and common very fine and medium roots; $30 \%$ rock fragments (15\% channers, $15 \%$ gravels); clear wavy boundary.

Bw1 -- 7.5 to $18 \mathrm{~cm}$ (3 to 7 in); dark yellowish brown (10YR 4/6) channery loam; moderate medium subangular blocky structure; friable; many fine and common very fine and medium roots; $30 \%$ rock fragments ( $15 \%$ channers, $15 \%$ gravels); clear wavy boundary.

Bw2 -- 18 to $33 \mathrm{~cm}$ (7 to 13 in); yellowish brown (10YR 5/6) channery loam; moderate medium subangular blocky structure; friable; few fine and common medium roots; few faint clay films on rock and ped faces; $30 \%$ rock fragments ( $20 \%$ channers, $10 \%$ cobbles); clear wavy boundary.

Bw3 -- 33 to $66 \mathrm{~cm}$ (13 to 26 in); yellowish brown (10YR 5/6) channery loam; moderate medium subangular blocky structure; friable; few fine and common medium roots; few faint clay films on rock and ped faces; $30 \%$ channers; clear wavy boundary.

BC1 -- 66 to $94 \mathrm{~cm}$ (26 to 37 in); dark yellowish brown (10YR 4/6) and yellowish brown (10YR 5/8) very channery silt loam; weak medium subangular blocky structure; friable; few medium roots; $50 \%$ rock fragments ( $40 \%$ channers, $10 \%$ flagstones); clear wavy boundary.

BC2 -- 94 to $122 \mathrm{~cm}$ (37 to 48 in); yellowish brown (10YR 5/6) very flaggy silt loam; weak medium subangular blocky structure; friable; few fine and medium roots; $60 \%$ rock fragments ( $40 \%$ flagstones, $20 \%$ channers); abrupt smooth boundary. 
$\mathbf{2 R}$-- $122+\mathrm{cm}(60+$ in); gray shale bedrock.

Notes: This site is located up the skid trail from the final log landing on FS rd. 944. The understory contains heavily browsed remnants of hay-scented fern, striped maple, wild yam, and greenbrier. There was no fragipan or dense layer found. 
Profile Number: 3

Soil Description Number: FS04WV025003

Sample Date: July 12, 2004

Soil Family: Typic Fragiudepts

Area: Summit Lake Rec. Area FS rd. 946

Location: (GPS) NAD27 38¹4.820N 80²5.147W EPE 89ft

Natural Vegetation: Black cherry, sugar maple, beech, red maple,

Soil Temp. Regime: frigid

Parent Material: Pottsville sandstone, residuum

Physiography: Allegheny Plateau (ridge)

Relief: convex

Drainage: moderately well drained

Elevation: $1123 \mathrm{~m}(3685 \mathrm{ft})$

Slope: $15 \%$

Aspect: E

Surface stoniness: $<0.01 \%$

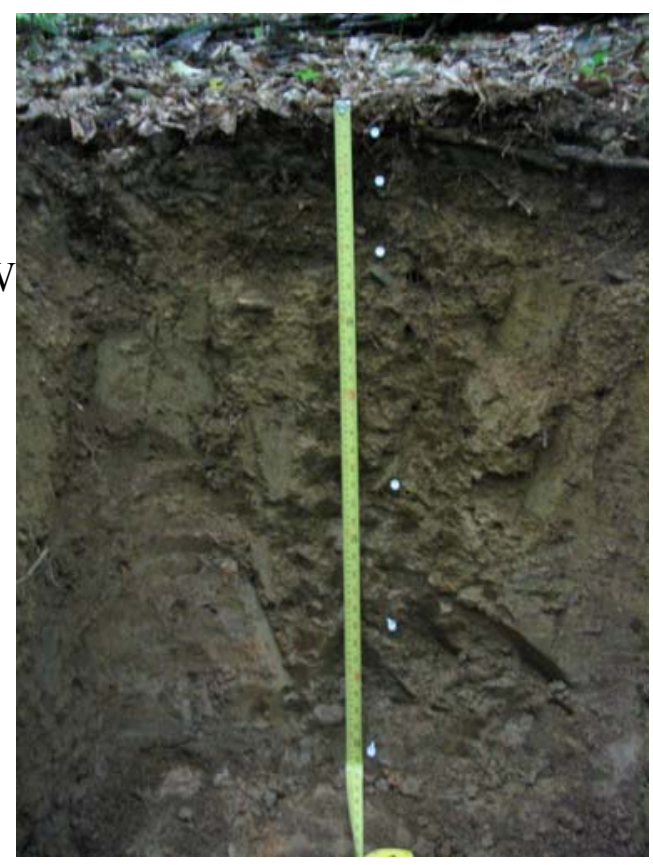

Site: FS04WV025003 described and sampled by Stephanie Connolly and Cara Sponaugle $\mathbf{O}$-- 0 to $5 \mathrm{~cm}$ (0 to $2 \mathrm{in})$.

A -- 5 to $10 \mathrm{~cm}$ (2 to 4 in); very dark grayish brown (10YR 3/2) loam; moderate medium granular and weak medium subangular blocky structure; very friable; many very fine to medium roots and few coarse roots; $<5 \%$ gravel; clear wavy boundary.

Bw1-- 10 to $20.5 \mathrm{~cm}$ (4 to 8 in); yellowish brown (10YR 5/6) heavy loam; moderate medium subangular blocky parting to moderate medium granular structure; friable; many medium roots and common very fine and fine roots; $<5 \%$ gravel; clear wavy boundary. Bw2 -- 20.5 to $53 \mathrm{~cm}$ (8 to 21 in); yellowish brown (10YR 5/8) clay loam; moderate medium subangular blocky structure; friable; common fine roots; few faint clay films on rock and ped faces; $<5 \%$ gravel; clear wavy boundary.

Bx1 -- 53 to $73.5 \mathrm{~cm}$ (21 to 29 in); yellowish brown (10YR 5/8) clay loam; moderate coarse subangular blocky structure; firm; common medium distinct light brownish gray (10YR 6/2) depletions and common medium distinct strong brown (7.5YR 5/8)

concentrations; few fine roots; few clear clay films on ped faces; $<5 \%$ gravel; clear wavy boundary.

Bx2 -- 73.5 to $91.5 \mathrm{~cm}$ (29 to 36 in); yellowish brown (10YR 5/4) clay loam; weak coarse prismatic parting to moderate coarse subangular blocky structure; firm; many medium distinct light and dark brownish gray (10YR 6/2 and 10YR 4/2) depletions and common medium distinct reddish yellow (7.5YR 6/8) concentrations on ped faces; many distinct clay films on rock and ped faces; $<5 \%$ gravel; clear wavy boundary.

Cr -- 91.5 to $96.5 \mathrm{~cm}$ (36 to 38 in); soft sandstone.

R -- 96.5+ cm (38+ in); sandstone.

Notes: This site is located above the final log landing on Forest Service Road 946. The understory consists of hay scented fern, greenbrier, red maple seedlings, moss, and beech 
regeneration but is affected by heavy deer browse. The midstory consists of beech, striped maple, and red spruce. This site has remnants of a past fire. 
Profile Number: 4

Soil Description Number: FS04WV025004

Sample Date: June 30, 2004

Soil Family: Fragic Dystrudepts

Area: Summit Lake Rec. Area

Location: (GPS) NAD27 38 $15.045 \mathrm{~N} 80^{\circ} 26.402 \mathrm{~W}$

EPE $56 \mathrm{ft}$

Natural Vegetation: Sugar maple, ash, white oak, black cherry, tulip poplar, red oak, cucumber magnolia, basswood

Soil Temp. Regime: frigid

Parent Material: Pottsville sandstone/ shale, colluvium Physiography: Allegheny Plateau (foot slope)

Relief: concave

Drainage: well-drained

Elevation: $1056 \mathrm{~m}(3465 \mathrm{ft})$

Slope: $20 \%$

Aspect: ESE

Surface stoniness: $0.001 \%$

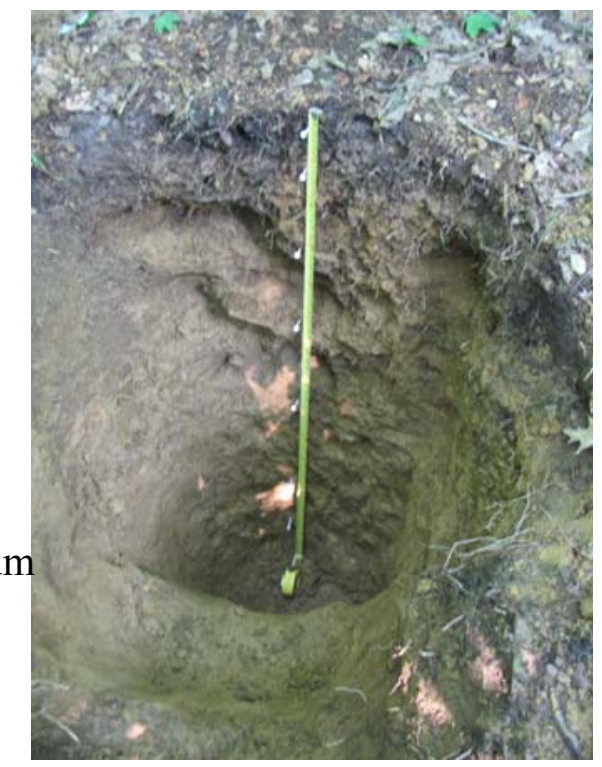

Site: FS04WV025004 described and sampled by Stephanie Connolly and Cara Sponaugle A -- 0 to $2.5 \mathrm{~cm}$ (0 to $1 \mathrm{in}$ ); black (10YR 2/1) mucky silt loam; moderate fine granular structure; very friable; many very fine and fine, common medium roots; $3 \%$ gravels; abrupt wavy boundary.

AB -- 2.5 to $12.5 \mathrm{~cm}$ (1 to 5 in); very dark grayish brown (10YR 3/2) loam; weak medium subangular blocky structure parting to moderate medium granular structure; friable; many fine and medium roots; $5 \%$ gravels; clear wavy boundary.

Bw1 -- 12.5 to $30.5 \mathrm{~cm}$ (5 to 12 in); dark yellowish brown (10YR 4/6) loam; weak and moderate medium subangular blocky structure; friable; common fine and medium roots; few faint clay films on rock faces; $8 \%$ rock fragments; clear wavy boundary.

Bw2 -- 30.5 to $51 \mathrm{~cm}$ (12 to 20 in); yellowish brown (10YR 5/4) gravelly loam; moderate medium and coarse subangular blocky structure; friable; few fine and medium roots; common faint clay films on rock and ped faces; $15 \%$ rock fragments (10\% gravel, $5 \%$ cobble); clear wavy boundary.

Bw3 -- 51 to $79 \mathrm{~cm}$ (20 to 31 in); yellowish brown (10YR 5/8) very gravelly clay loam; moderate medium and coarse subangular blocky structure; friable; $35 \%$ rock fragments ( $20 \%$ gravel, $15 \%$ channers); common faint clay films on rock and ped faces; clear wavy boundary.

2Bw4 -- 79 to $109 \mathrm{~cm}$ (31 to 43 in); yellowish brown (10YR 5/6) gravelly loam; moderate medium and coarse subangular blocky structure; friable; common faint clay films on rock and ped faces; $20 \%$ rock fragments ( $15 \%$ gravel, $5 \%$ channers); clear wavy boundary.

2Bx -- 109 to $129.5 \mathrm{~cm}$ (43 to 51 in); yellowish brown (10YR 5/8) gravelly clay loam; moderate medium and coarse subangular blocky structure; firm; many medium and few fine distinct light gray (10YR 7/1) depletions and common medium distinct yellowish red 
(5YR 5/6) concentrations; common faint clay films on rock and ped faces; $20 \%$ rock fragments ( $15 \%$ gravel, $5 \%$ channers); clear wavy boundary.

3BC -- 129.5 to $145+\mathrm{cm}$ (51 to $57+$ in); yellowish brown (10YR 5/6) very channery loam; weak medium subangular blocky structure; firm; few medium and fine distinct light gray (10YR 7/1) depletions; $40 \%$ rock fragments (25\% channers, $15 \%$ gravel).

Notes: This site is located north of lower campground and west of Summit Lake. The understory is made up of witch hazel, hay scented fern and forest grasses. The $2 \mathrm{Bt}$ and 2Btx have glitter in them that appears to be mica flakes. The 2Btx horizon has fragic characteristics but is not a true fragipan. 
Profile Number: 5

Soil Description Number: FS04WV025005

Sample Date: June 30, 2004

Soil Family: Typic Fragiudepts

Area: Summit Lake Rec. Area

Location: (GPS) NAD27 38 $15.104 \mathrm{~N} \quad 80^{\circ} 26.688 \mathrm{~W}$ EPE $75 \mathrm{ft}$

Natural Vegetation: Black cherry, red oak, sugar maple

Soil Temp. Regime: frigid

Parent Material: Pottsville sandstone/ shale, colluvium

Physiography: Allegheny Plateau (bench)

Relief: concave

Drainage: well-drained

Elevation: $1102 \mathrm{~m}(3615 \mathrm{ft})$

Slope: $24-25 \%$

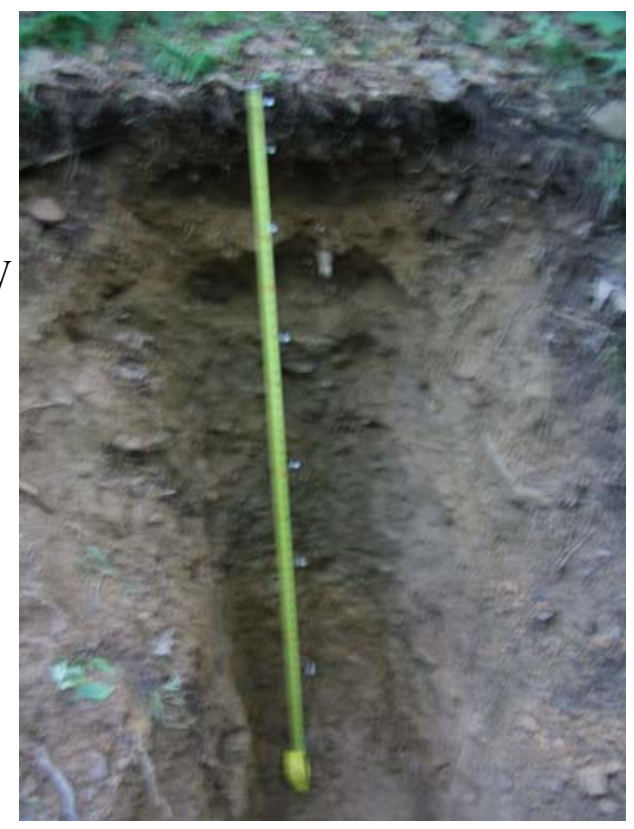

Aspect: SW

Surface stoniness: $0.001 \%$

Site: FS04WV025005 described and sampled by Stephanie Connolly and Cara Sponaugle $\mathbf{O}--2.5$ to $0 \mathrm{~cm}$ (1 to 0 in); decaying oak leaves.

A -- 0 to $2.5 \mathrm{~cm}$ (0 to 1 in); black (10YR 2/1) mucky silt loam; moderate fine granular structure; very friable; many very fine and fine, and common medium roots; $<5 \%$ channers; abrupt wavy boundary.

AB-- 2.5 to $13 \mathrm{~cm}$ (1 to 5 in); dark yellowish brown (10YR 4/4) and dark brown (10YR 3/3) silt loam; weak medium subangular blocky parting to moderate fine granular structure; friable; many very fine and fine, common medium, and few coarse roots; $<5 \%$ channers; clear wavy boundary.

Bw1 -- 13 to $25.5 \mathrm{~cm}$ (5 to 10 in); dark yellowish brown (10YR 4/4) silt loam; moderate fine and medium subangular blocky structure; friable; many very fine and fine, common medium, few coarse roots; $10 \%$ gravels; clear wavy boundary.

Bw2 -- 25.5 to $48 \mathrm{~cm}$ (10 to 19 in); dark yellowish brown (10YR 4/6) gravelly loam; moderate fine and medium subangular blocky structure; friable; few fine and common medium roots; common distinct clay films on rock and ped faces; $25 \%$ rock fragments ( $15 \%$ gravels, $10 \%$ cobbles); clear wavy boundary.

2Bx1 -- 48 to $79 \mathrm{~cm}$ (19 to $31 \mathrm{in}$ ); brown (10YR 5/3) very gravelly clay loam; moderate medium subangular blocky structure; firm; few fine roots; many distinct clay films on rock and ped faces; $45 \%$ rock fragments (30\% gravels, $15 \%$ shale channers); clear wavy boundary.

2Bx2 -- 79 to $104 \mathrm{~cm}$ (31 to 41 in); dark brown (10YR 4/3) extremely gravelly clay loam; moderate medium subangular blocky structure; firm; common medium gray (10YR 5/1) depletions and common medium reddish yellow (5YR 6/8) concentrations; 65\% rock fragments (50\% gravels, $15 \%$ shale channers); many distinct clay films on rock and ped faces; clear wavy boundary. 
3Bx3 -- 109 to $127 \mathrm{~cm}$ (41 to 50 in); yellowish brown (10YR 5/6) channery clay; moderate medium subangular blocky structure; firm; common medium light grayish brown (10YR 6/2) depletions and common medium strong brown (7.5YR 5/8) concentrations; $30 \%$ rock fragments ( $20 \%$ channers, $10 \%$ gravels); many distinct clay films on rock and ped faces; clear wavy boundary. 3BC -- 127 to $152.5+\mathrm{cm}(50$ to $60+$ in); dark yellowish brown (10YR 4/4) very channery clay; weak coarse subangular blocky structure; firm; common medium light grayish brown (10YR 6/2) depletions and common medium strong brown (7.5YR 5/6) concentrations; $40 \%$ rock fragments ( $30 \%$ channers, $10 \%$ gravels).

Notes: This site is located NW of the upper campground in the bank of an old forest road. The understory consists of hay scented fern, greenbrier, and violet. The Btx horizons all show fragic characteristics but are not true fragipans. 
Profile Number: 17

Soil Description Number: FS04WV025010

Sample Date: June 20, 2004

Soil Family: Typic Fragiudults

Area: Summit Lake Rec. Area FS rd. 943

Location: (GPS) NAD83 38 $14.904 \mathrm{~N} 80^{\circ} 25.648 \mathrm{~W}$ EPE 52ft

Natural Vegetation: Red maple, beech, sugar maple, black cherry

Soil Temp. Regime: frigid

Parent Material: Pottsville sandstone/shale, residuum

Physiography: Allegheny Plateau (shoulder)

Relief: convex

Drainage: moderately well drained

Elevation: $1126 \mathrm{~m}(3695 \mathrm{ft})$

Slope: $17 \%$

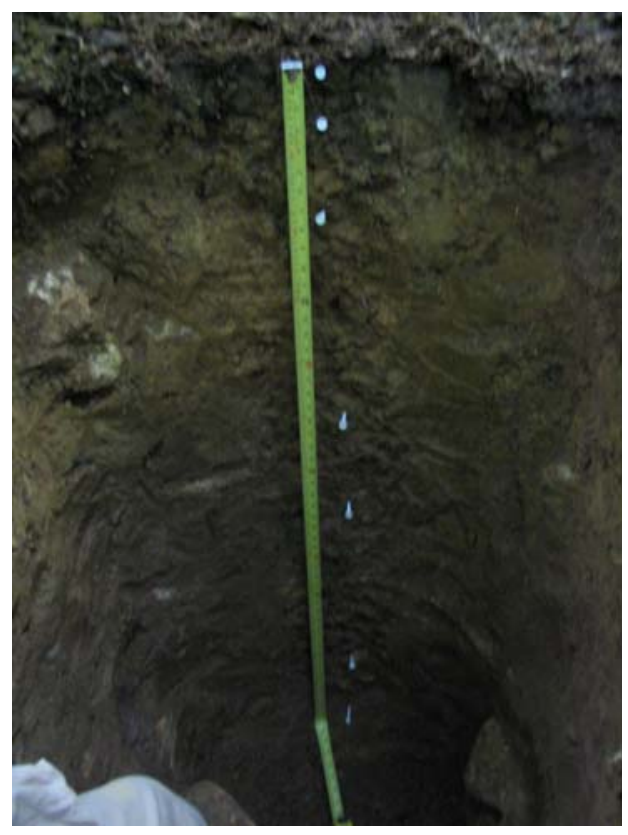

Aspect: WSW

Surface stoniness: $<0.01 \%$

Site: FS04WV025010 described and sampled by Stephanie Connolly and Cara Sponaugle Oi -- 0 to $2.5 \mathrm{~cm}$ (0 to $1 \mathrm{in})$.

A/E -- 2.5 to $7.5 \mathrm{~cm}$ (1 to 3 in); dark brown (10YR 3/3) and dark grayish brown (10YR4/2) loam; moderate medium granular and weak medium subangular blocky structure; friable; many very fine and fine, and common medium roots; $<5 \%$ channers; abrupt wavy boundary.

BA-- 7.5 to $20 \mathrm{~cm}$ (3 to 8 in); yellowish brown (10YR 5/4 and 10YR 5/6) loam; weak medium subangular blocky structure; friable; common very fine and many fine and medium roots; $<5 \%$ channers; clear wavy boundary.

Bt -- 20 to $53 \mathrm{~cm}$ (8 to $21 \mathrm{in}$ ); yellowish brown (10YR 5/6) very flaggy loam; moderate medium subangular blocky structure; friable; few very fine, common fine, and many medium roots; common faint clay films on rock and ped faces; $35 \%$ flagstones; clear wavy boundary.

Btx1 -- 53 to $73.5 \mathrm{~cm}$ (21 to 29 in); yellowish brown (10YR 5/4) cobbly loam; weak medium subangular blocky parting to weak medium platy structure; firm; common distinct light brownish gray (10YR 6/2) depletions and brownish yellow (10YR 6/6) and reddish yellow (7.5YR 5/8) concentrations; many distinct clay films on rock and ped faces; $15 \%$ cobbles; clear wavy boundary.

Btx2 -- 73.5 to $124.5 \mathrm{~cm}$ (29 to 49 in); brownish yellow (10YR 6/8) very stony loam; weak medium subangular blocky parting to weak medium platy structure; firm; many distinct light gray (10YR 7/1) and light brownish gray (10YR 6/2) depletions and brownish yellow (10YR 6/6) and reddish yellow (5YR 6/8) concentrations; many distinct manganese concentrations on rock faces; many distinct clay films on rock and ped faces; $40 \%$ rock fragments ( $35 \%$ stones, $5 \%$ cobbles); clear wavy boundary.

BC -- 124.5 to $13 \mathrm{~cm}$ (49 to 54 in); yellowish brown (10YR 5/8) cobbly loam; weak coarse subangular blocky structure; firm; many distinct light gray (10YR 7/1) and light 
brownish gray (10YR 6/2) depletions and reddish yellow (5YR 6/8) concentrations; many distinct manganese concentrations on rock faces; $15 \%$ cobbles; clear wavy boundary. Cr -- 137+ cm (54+ in); sandstone.

Notes: This site is located NW above the final log landing on Forest Service Rd. 943. The understory consists of hay-scented fern, cherry seedlings, grasses, moss, red maple, beech, sugar maple, and violet. The midstory consists of striped maple, red maple, yellow birch, and beech. 
Profile Number: 37

Soil Description Number: FS04WV025019

Sample Date: July 20, 2004

Soil Family: Oxyaquic Dystrudepts

Area: Summit Lake Rec. Area FS rd. 945

Location: (GPS) NAD83 38 $14.812 \mathrm{~N} 80^{\circ} 25.801 \mathrm{~W}$ EPE $62 \mathrm{ft}$

Natural Vegetation: Black cherry, red maple, sugar maple, yellow birch, basswood, magnolia

Soil Temp. Regime: frigid

Parent Material: Pottsville sandstone/ shale, alluvium

Physiography: Allegheny Plateau (floodplain)

Relief: convex

Drainage: well-drained

Elevation: $1067 \mathrm{~m}(3500 \mathrm{ft})$

Slope: $8 \%$

Aspect: SW

Surface stoniness: $<0.01 \%$

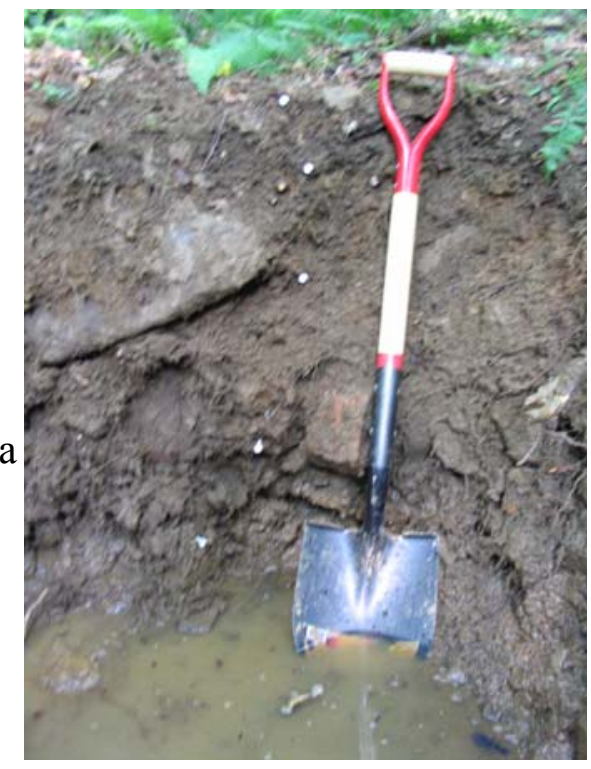

Site: FS04WV025019 described and sampled by Stephanie Connolly and Cara Sponaugle $\mathbf{O}--0$ to $2.5 \mathrm{~cm}$ (0 to $1 \mathrm{in}$ ).

A -- 2.5 to $13 \mathrm{~cm}$ (1 to 5 in); dark brown (10YR 3/3) silt loam; moderate medium granular structure; very friable; many very fine to medium and common coarse roots; $1 \%$ boulders; abrupt wavy boundary.

Bw1-- 13 to $30.5 \mathrm{~cm}$ (5 to 12 in); dark yellowish brown (10YR 4/4) very channery loam; weak medium subangular blocky and moderate fine granular structure; very friable; common very fine and many fine and medium, and few coarse roots around rocks; 55\% rock fragments ( $40 \%$ channers, $15 \%$ gravels); clear wavy boundary.

Bw2 -- 30.5 to $58.5 \mathrm{~cm}$ (12 to 23 in); brown (10YR 4/3) extremely gravelly loam; weak medium subangular blocky parting to moderate fine granular structure; very friable; few very fine and coarse, and many fine and medium roots around rocks; $80 \%$ rock fragments ( $30 \%$ cobbles, $50 \%$ gravels); clear wavy boundary.

Bw3 -- 58.5 to $73.5 \mathrm{~cm}$ (23 to 29 in); dark yellowish brown (10YR 5/4) extremely gravelly silt loam; weak medium subangular blocky parting to moderate fine granular structure; very friable; $80 \%$ rock fragments ( $30 \%$ cobbles, $50 \%$ gravels); abrupt wavy boundary.

BC -- 73.5+ cm (29+ in); brownish yellow (10YR 6/8) very gravelly loam; weak medium subangular blocky parting to weak medium platy structure; firm; many distinct light gray (10YR 7/1) depletions and brownish yellow (10YR 6/8) and yellowish brown (10YR 5/8) concentrations; many distinct black manganese concentrations throughout; $50 \%$ rock fragments ( $40 \%$ gravels, $10 \%$ cobbles).

Notes: This site is located NW beyond the log landing on Forest Service Road 945. The understory consists of hay-scented fern, striped maple, and beech. The midstory consists of magnolia, red maple, ironwood, and beech. There is a perched water table with free 
flowing water at one gallon per minute in the BA and Ab horizons. Water does not flow through the $\mathrm{BC}$ horizon. 


\section{Profile Number: 7}

Soil Description Number: FS04WV101001

Sample Date: June 30, 2004

Soil Family: Typic Hapludults

Area: Summit Lake Rec. Area FS rd. 99

Location: (GPS) NAD27 38 $16.286 \mathrm{~N} 80^{\circ} 26.387 \mathrm{~W}$ EPE $58 \mathrm{ft}$ $17548996 \mathrm{E} 4235883 \mathrm{~N}$

Natural Vegetation: Black cherry, sugar maple, striped maple

Soil Temp. Regime: frigid

Parent Material: Pottsville sandstone/ gray shale, residuum

Physiography: Allegheny Plateau (ridge)

Relief: convex

Drainage: well-drained

Elevation: $1132 \mathrm{~m}(3715 \mathrm{ft})$

Slope: $12-13 \%$

Aspect: NW

Surface stoniness: $<0.01 \%$

Site: FS04WV101001 described and sampled by Stephanie Connolly and Cara Sponaugle Oi -- 2.5 to $0 \mathrm{~cm}$ ( 1 to 0 in).

Oe -- 0 to $2.5 \mathrm{~cm}$ (0 to $1 \mathrm{in})$; many very fine and fine and common coarse roots; abrupt wavy boundary.

A -- 2.5 to $5 \mathrm{~cm}$ ( 1 to 2 in); black (10YR 2/1) loam; moderate very fine and fine granular structure; very friable; many very fine to medium roots; $<5 \%$ channers; abrupt wavy boundary.

BA-- 5 to $10 \mathrm{~cm}$ (2 to 4 in); dark grayish brown (10YR 4/2) loam; weak and moderate medium subangular blocky structure; friable; many very fine to medium roots; $5 \%$ channers; abrupt wavy boundary.

Bt1 -- 10 to $25.5 \mathrm{~cm}$ (4 to 10 in); dark yellowish brown (10YR 4/6) loam; moderate medium subangular blocky; friable; common very fine to medium roots; $10 \%$ channers; few faint clay films on rock and ped faces; abrupt wavy boundary.

Bt2 -- 25.5 to $48 \mathrm{~cm}$ (10 to 19 in); yellowish brown (10YR 5/8) loam; moderate medium subangular blocky structure; firm; common very fine to medium roots; many distinct clay films on rock and ped faces; $13 \%$ channers; clear wavy boundary.

Bt3 -- 48 to $61 \mathrm{~cm}$ (19 to 24 in); dark yellowish brown (10YR 4/6) loam; moderate medium subangular blocky structure; friable; few fine and medium roots matted around rock fragments; common distinct clay films on rock and ped faces; $10 \%$ channers; abrupt wavy boundary.

Cr -- 61 to $79 \mathrm{~cm}$ (24 to $31 \mathrm{in})$; soft gray shale.

$\mathbf{R}--79+\mathrm{cm}(31+\mathrm{in})$; gray shale.

Notes: This site is located SE of the intersection of FS Road 99 and FS road 786. This is the highest point of the Summit Lake area. The understory consists of hay scented fern, greenbrier, cherry regeneration, and several forest grasses but is affected by heavy deer browse. In both the BA and Bt1 horizons organic matter follows the root channels. 
Profile Number: 23

Soil Description Number: FS04WV067007

Sample Date: September 22, 2004

Soil Family: Typic Dystrudepts

Area: Summit Lake Rec. Area FS rd.99A

Location: (GPS) NAD27 38 $16.152 \mathrm{~N} 80^{\circ} 27.831 \mathrm{~W}$ EPE $52 \mathrm{ft}$

Natural Vegetation: Red maple, red oak, beech, cucumber magnolia

Soil Temp. Regime: frigid

Parent Material: Pottsville gray shale, residuum

Physiography: Allegheny Plateau (shoulder)

Relief: concave

Drainage: well-drained

Elevation: $1094 \mathrm{~m}(3590 \mathrm{ft})$

Slope: $13 \%$

Aspect: SW

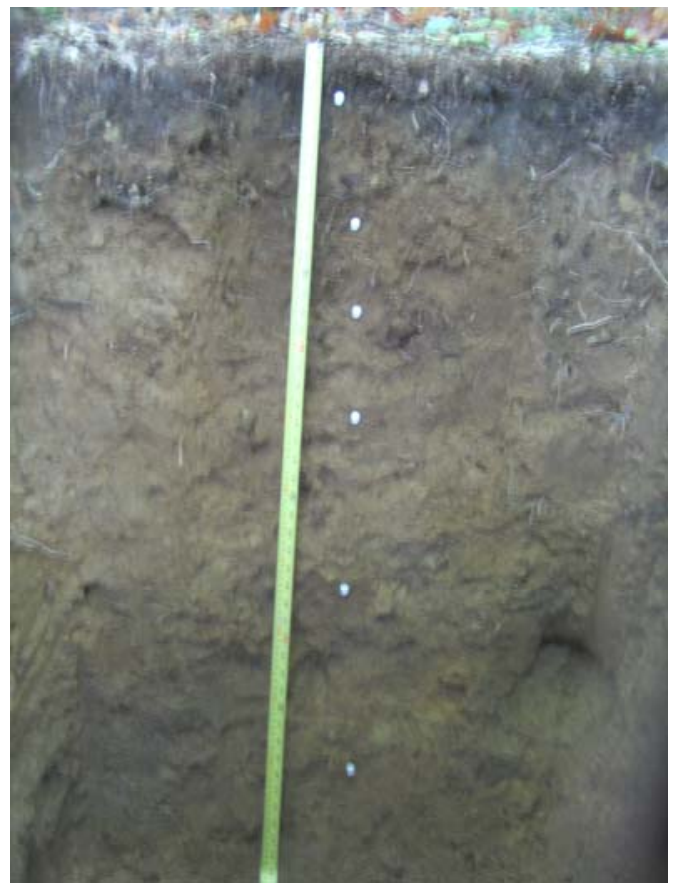

Surface stoniness: $<0.01 \%$

Site: FS04WV067007 described and sampled by Cara Sponaugle

Oi -- 0 to $2.5 \mathrm{~cm}$ (0 to 1 in).

A -- 2.5 to $7.5 \mathrm{~cm}$ (1 to 3 in); very dark grayish brown (10YR 3/2) loam; moderate medium granular structure; very friable; many very fine and fine roots; $<10 \%$ channers; abrupt wavy boundary.

BA -- 7.5 to $23 \mathrm{~cm}$ (3 to 9 in); dark yellowish brown (10YR 4/6) loam; moderate medium granular and moderate medium subangular blocky structure; very friable; many very fine and fine and common medium roots; $<10 \%$ channers; abrupt wavy boundary.

Bw1 -- 23 to $33 \mathrm{~cm}$ (9 to 13 in); yellowish brown (10YR 5/6) loam; moderate medium subangular blocky structure; friable; many very fine and fine and common medium roots; few faint clay skins on rock and ped faces; $<10 \%$ channers; clear wavy boundary.

Bw2 -- 33 to $48 \mathrm{~cm}$ (13 to 19 in); yellowish brown (10YR 5/6) clay loam; moderate medium subangular blocky structure; friable; common fine and few coarse roots; common faint clay films on rock and ped faces; $10 \%$ channers; clear wavy boundary. Bw3 -- 48 to $73.5 \mathrm{~cm}$ (19 to 29 in); yellowish brown (10YR 5/6) channery clay loam; moderate medium subangular blocky structure; friable; few fine roots; common distinct clay films on rock and ped faces; $30 \%$ channers; clear wavy boundary.

BC -- 73.5 to $101.5 \mathrm{~cm}$ (29 to 40 in); yellowish brown (10YR 5/6) very channery clay loam; weak medium subangular blocky structure; friable; few fine roots around rock fragments; $45 \%$ channers; clear wavy boundary.

Cr -- 101.5 to $117 \mathrm{~cm}$ (40 to 46 in); soft weathered shale.

$\mathbf{R}$-- $117+\mathrm{cm}(46+$ in); black shale bedrock.

Notes: This site is located above the final log landing on FS Rd 99A. The understory contains beech seedlings, oak seedlings, and greenbrier. 
Profile Number: 6

Soil Description Number: FS04WV067001

Sample Date: September 2, 2004

Soil Family: Fragic Dystrudepts

Area: Summit Lake Rec. Area FS rd. 943

Location: (GPS) NAD27 38 $16.779 \mathrm{~N} \quad 80^{\circ} 36.683 \mathrm{~W}$ EPE $52 \mathrm{ft}$

Natural Vegetation: White oak, yellow poplar, chestnut oak

Soil Temp. Regime: frigid

Parent Material: Pottsville sandstone, colluvium

Physiography: Allegheny Plateau (back slope)

Relief: concave

Drainage: well-drained

Elevation: $1125 \mathrm{~m}(3690 \mathrm{ft})$

Slope: $30 \%$

Aspect: NW

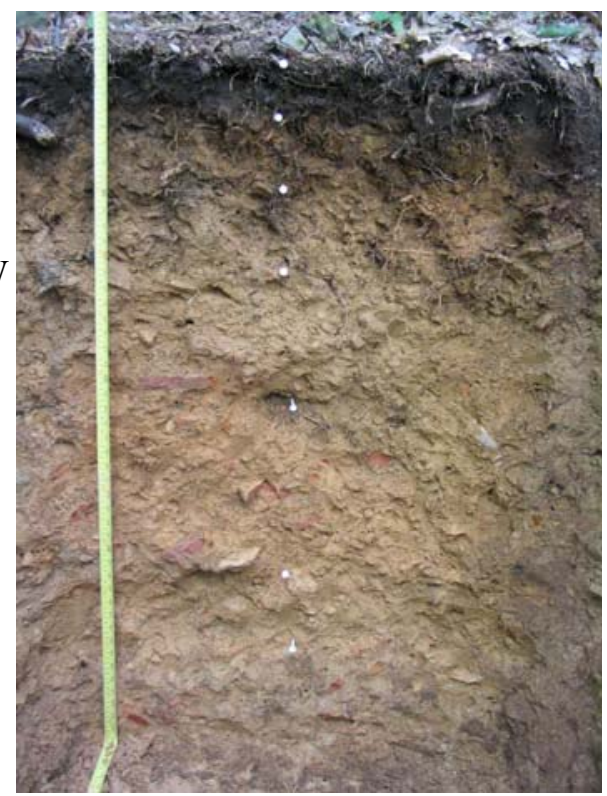

Surface stoniness: $0.01 \%$

Site: FS04WV067001 described and sampled by Stephanie Connolly

Oi -- 5 to $0 \mathrm{~cm}$ (2 to 0 in).

A -- 0 to $13 \mathrm{~cm}$ ( 0 to 5 in); black (10YR 2/2) very channery loam; moderate very fine and fine granular structure; very friable; many very fine and fine, and few coarse and medium roots throughout; $40 \%$ rock fragments ( $30 \%$ channers, $10 \%$ gravels); clear wavy boundary.

AB-- 13 to $25.5 \mathrm{~cm}$ (5 to 10 in); dark yellowish brown (10YR 4/4 and 10YR 4/6) channery loam; weak fine granular and weak medium subangular blocky structure; very friable; many very fine and common fine and medium roots; $20 \%$ rock fragments $(15 \%$ channers, $5 \%$ gravels); clear wavy boundary.

BA -- 25.5 to $38 \mathrm{~cm}$ (10 to $15 \mathrm{in}$ ); dark yellowish brown (10YR 4/6) very channery loam; weak medium subangular blocky structure; friable; many fine, common medium, and few coarse roots; $40 \%$ rock fragments ( $30 \%$ channers, $10 \%$ gravels); clear wavy boundary.

Bw1 -- 38 to $61 \mathrm{~cm}$ (15 to 24 in); yellowish brown (10YR 5/6) very channery loam; moderate medium subangular blocky structure; friable; common faint clay films on rock and ped faces; common fine roots; $40 \%$ rock fragments ( $30 \%$ channers, $10 \%$ gravels); clear wavy boundary.

Bw2 -- 61 to $91.5 \mathrm{~cm}$ (24 to 36 in); yellowish brown (10YR 5/6) very channery sandy loam; weak fine prismatic and weak medium subangular blocky structure; firm; few fine roots; few faint clay films on rock faces; $50 \%$ rock fragments (35\% channers, $10 \%$ gravels, $5 \%$ flagstones); clear wavy boundary.

Bw3 -- 91.5 to $106.5 \mathrm{~cm}$ (36 to 42 in); yellowish brown (10YR 5/8) very channery sandy loam; weak medium subangular blocky structure; firm; few fine roots; $37 \%$ rock fragments ( $35 \%$ channers, $2 \%$ flagstones); abrupt wavy boundary. C -- 106.5 to $129.5 \mathrm{~cm}$ (42 to $51 \mathrm{in}$ ); yellowish brown (10YR 5/8) very channery sandy loam; massive; firm; $37 \%$ rock fragments (35\% channers, $2 \%$ flagstones); clear wavy boundary. 
Cr -- 129.5+ cm $(51+$ in $)$; paralithic sandstone.

Notes: This site is located below Forest Service Rd. 943. The understory consists of hayscented fern, moss, red oak, white oak, mountain laurel, greenbrier, and rubus. 
Profile Number: 8

Soil Description Number: FS04WV067002

Sample Date: July 29, 2004

Soil Family: Typic Dystrudepts

Area: Holcom Rd.

Location: (GPS) NAD83 38 $16.225 \mathrm{~N} 80^{\circ} 33.759 \mathrm{~W}$ EPE $62 \mathrm{ft}$

Natural Vegetation: White oak, red oak, sugar maple, beech

Soil Temp. Regime: mesic

Parent Material: Pottsville sandstone, residuum

Physiography: Allegheny Plateau (ridge)

Relief: concave

Drainage: well-drained

Elevation: $914.5 \mathrm{~m}(3000 \mathrm{ft})$

Slope: $2 \%$

Aspect: W aspect

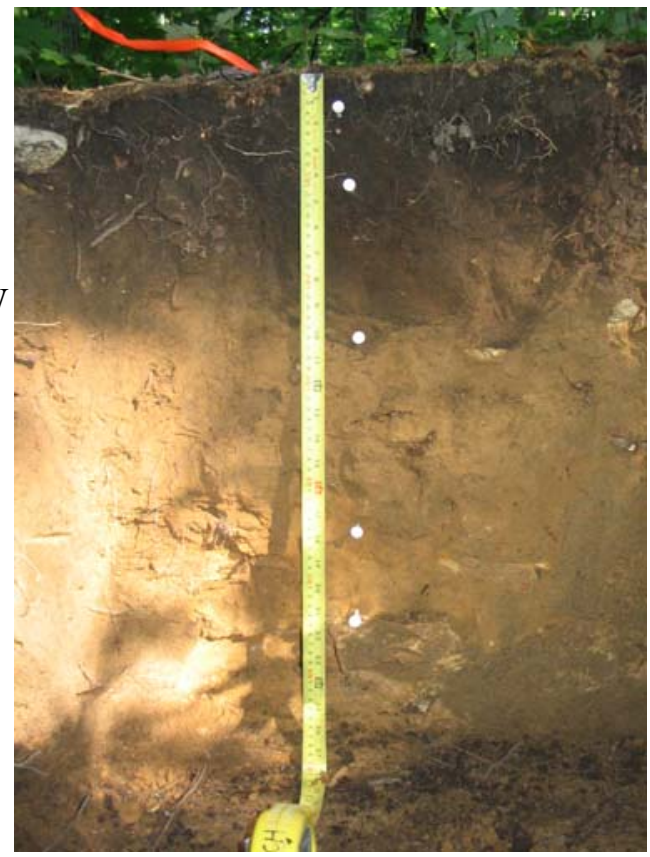

Surface stoniness: $<1 \%$

Site: FS04WV067002 described and sampled by Stephanie Connolly and Cara Sponaugle $\mathbf{O}$-- 0 to $2.5 \mathrm{~cm}$ (0 to $1 \mathrm{in})$.

A -- 2.5 to $10 \mathrm{~cm}$ (1 to 4 in); very dark brown (10YR 2/2) loam; moderate medium granular structure; very friable; many very fine and fine roots and few medium roots; $10 \%$ stones; clear wavy boundary.

BA-- 10 to $25.5 \mathrm{~cm}$ (4 to $10 \mathrm{in}$ ); dark brown (10YR 4/3) loam; moderate medium granular and moderate medium subangular blocky structure; friable; common very fine and fine roots; $5 \%$ channers; clear wavy boundary.

Bw1 -- 25.5 to $43 \mathrm{~cm}$ (10 to 17 in); yellowish brown (10YR 5/6) very channery sandy loam; moderate medium subangular blocky structure; friable; few fine and medium roots throughout; $30 \%$ channers; clear wavy boundary.

Bw2 -- 43 to $53 \mathrm{~cm}$ (17 to 21 in); yellowish brown (10YR 5/8) extremely channery sandy loam; moderate medium subangular blocky structure; friable; few fine roots on rock faces; $60 \%$ channers; clear wavy boundary.

Cr -- 53 to $71 \mathrm{~cm}$ (21 to $28 \mathrm{in})$; soft sandstone.

R -- 71+cm (28+ in); sandstone.

Notes: This site is located on the ridge at the top of Holcom Rd. The understory consists of striped maple, witch hazel, red oak seedlings, greenbrier, and hay-scented fern. 
Profile Number: 9

Soil Description Number: FS04WV067003

Sample Date: September 2, 2004

Soil Family: Typic Dystrudepts

Area: Morris Creek, Holcom Rd.

Location: (GPS) NAD83 38 $15.548 \mathrm{~N} 80^{\circ} 33.751 \mathrm{~W}$ EPE $33 \mathrm{ft}$

Natural Vegetation: White oak, red oak, sugar maple white ash

Soil Temp. Regime: mesic

Parent Material: Pottsville sandstone, residuum

Physiography: Allegheny Plateau (ridge)

Relief: concave

Drainage: moderately well drained

Elevation: $859.5 \mathrm{~m}(2820 \mathrm{ft})$

Slope: $1 \%$

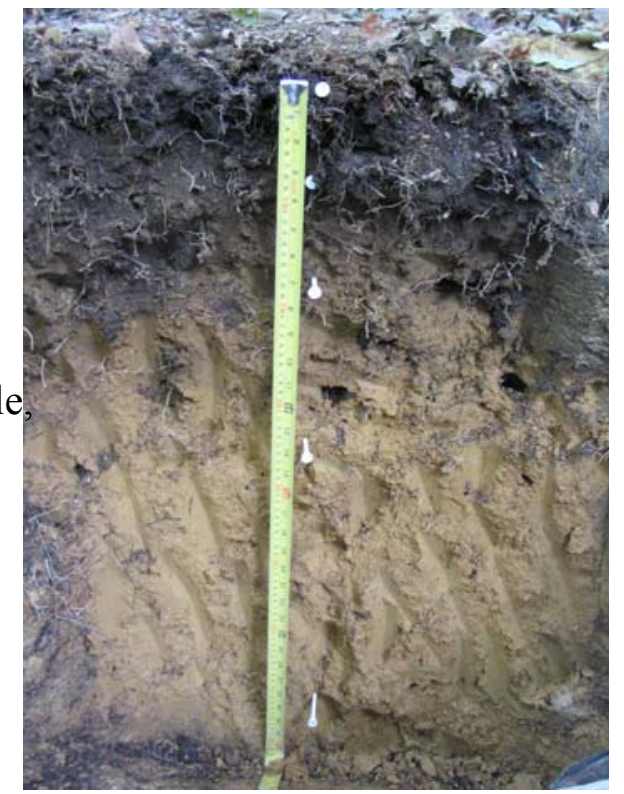

Aspect: N

Surface stoniness: $0.1 \%$ boulders and stones

Site: FS04WV067003 described and sampled by Stephanie Connolly

$\mathbf{O i}--2.5$ to $0 \mathrm{~cm}$ ( 1 to 0 in). Leaf litter and very dense root mat of very fine roots.

A -- 0 to $7.5 \mathrm{~cm}$ ( 0 to 3 in); very dark brown (10YR 2/2) loam; moderate very fine and

fine granular structure; very friable; many very fine and fine and few medium roots; $10 \%$ gravels; clear wavy boundary.

AB -- 7.5 to $18 \mathrm{~cm}$ (3 to 7 in); dark brown (10YR 4/3) loam; moderate medium granular and weak medium subangular blocky structure; friable; common fine and medium and few very fine roots; $5 \%$ gravels; clear wavy boundary.

Bw1 -- 18 to $35.5 \mathrm{~cm}$ (7 to 14 in); dark yellowish brown (10YR 4/6) loam; moderate medium subangular blocky structure; friable; common distinct clay skins on ped faces; common fine and coarse and few medium roots; $5 \%$ gravels; clear wavy boundary.

Bw2 -- 35.5 to $73.5 \mathrm{~cm}$ (14 to 29 in); yellowish brown (10YR 5/6) very bouldery loam; moderate medium subangular blocky structure; friable; common distinct clay skins on ped faces; few fine roots on rock faces; $50 \%$ boulder; clear wavy boundary.

BC -- 73.5 to $89 \mathrm{~cm}$ (29 to 35 in); yellowish brown (10YR 5/6) very bouldery sandy loam; weak medium subangular blocky structure; friable; common distinct light brown (10YR 6/4) depletions and weak faint strong brown (7.5YR 5/8) concentrations; 50\% boulders; abrupt smooth boundary.

$\mathbf{R}$-- 89+ cm (35+ in); coarse red sandstone boulder or bedrock.

Notes: This site is located above St Road 39 above the rock wall. The understory consists of blue cohosh, sugar maple seedlings, red maple seedlings, trillium, and jack-inthe-pulpit. Large pockets of A horizon material is translocated through the profile along boulders. 
Profile Number: 10

Soil Description Number: FS04WV067004

Sample Date: July 13, 2004

Soil Family: Fluventic Dystrudepts

Area: FS rd 943 - Coal Siding Run

Location: (GPS) NAD83 38¹6.693N 80³6.462W EPE $43 \mathrm{ft}$

Natural Vegetation: Tulip poplar, yellow birch, red maple, black birch, shagbark hickory

Soil Temp. Regime: mesic

Parent Material: Pottsville sandstone, alluvium

Physiography: Allegheny Plateau (floodplain)

Relief: concave

Drainage: somewhat poorly drained

Elevation: $731.5 \mathrm{~m}(2400 \mathrm{ft})$

Slope: $8 \%$

Aspect: WSW aspect

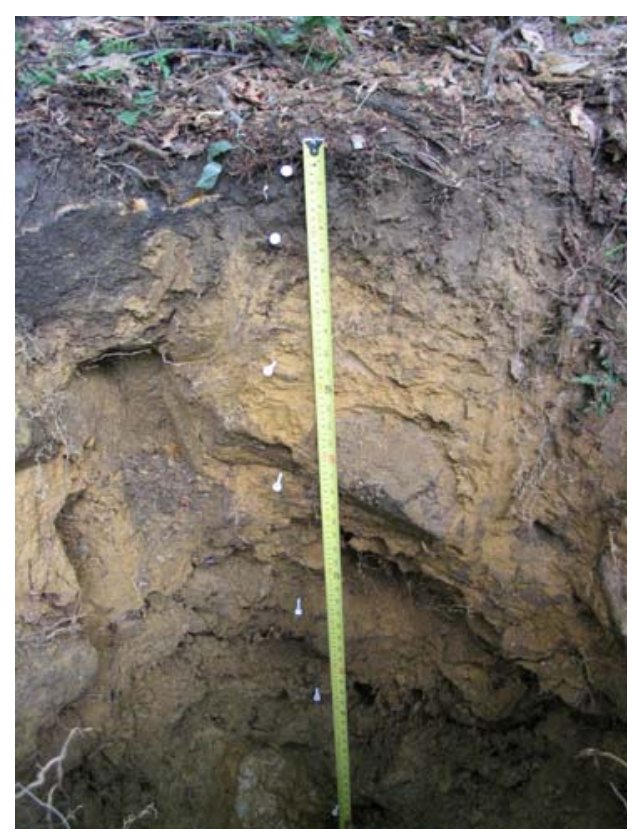

Surface stoniness: $70 \%$ bouldery

Site: FS04WV067004 described and sampled by Stephanie Connolly and Cara Sponaugle $\mathbf{O}$-- 0 to $5 \mathrm{~cm}$ (0 to 2 in).

A -- 5 to $13 \mathrm{~cm}$ (2 to 5 in); dark brown (10YR 3/3) extremely bouldery silt loam; moderate medium granular structure; very friable; many very fine and fine and few coarse roots; $80 \%$ rock fragments ( $60 \%$ boulders, $20 \%$ cobbles); gradual wavy boundary. BA-- 13 to $30 \mathrm{~cm}$ (5 to $11 \mathrm{in}$ ); yellowish brown (10YR 5/4) extremely bouldery silt loam; weak fine granular and moderate medium subangular blocky structure; friable; common distinct black manganese coatings on rock faces; many very fine and fine and few coarse roots around rocks; $80 \%$ rock fragments ( $60 \%$ boulders, $20 \%$ cobbles); gradual wavy boundary.

Bw1 -- 30 to $48 \mathrm{~cm}$ (11 to 19 in); yellowish brown (10YR 5/8) extremely bouldery loam; moderate medium subangular blocky structure; friable; many distinct black manganese coatings on rock faces; common very fine and fine roots around rocks; $85 \%$ rock fragments ( $60 \%$ boulders, $25 \%$ cobbles); gradual wavy boundary.

Bw2 -- 48 to $84 \mathrm{~cm}$ (19 to 33 in); yellowish brown (10YR 5/6) extremely bouldery loam; moderate medium subangular blocky structure; friable; common light yellowish brown (10YR 6/4) depletions in pores; common distinct black manganese coatings on rock faces; common very fine and fine roots around rocks; $85 \%$ rock fragments $(60 \%$ boulders, $25 \%$ cobbles); gradual wavy boundary.

$2 \mathbf{A b}$-- 84 to $101.5 \mathrm{~cm}$ (33 to 40 in); dark yellowish brown (10YR 4/4) extremely bouldery silt loam; weak medium subangular blocky structure; friable; common fine roots around rocks; $85 \%$ rock fragments ( $60 \%$ boulders, $25 \%$ cobbles); gradual wavy boundary.

2C1 -- 101.5 to $107 \mathrm{~cm}$ (40 to 42 in); dark brown (10YR 4/3) extremely bouldery loamy sand; single grain; loose; common distinct light gray (10YR 7/2) depletions and common distinct yellowish brown (10YR 5/8) concentrations; $85 \%$ rock fragments $(60 \%$ boulders, $25 \%$ cobbles); gradual irregular boundary. 
$2 C 2$-- 107 to $127 \mathrm{~cm}$ (42 to $50 \mathrm{in})$; yellowish brown (10YR 5/6) extremely bouldery loamy sand; single grain; loose; $85 \%$ rock fragments (60\% boulders, $25 \%$ cobbles); clear wavy boundary.

$\mathbf{2 C 3}-127$ to $157.5+\mathrm{cm}$ (50 to $62+$ in); yellowish brown (10YR 5/6) extremely bouldery sand; single grain; loose; $85 \%$ rock fragments $(60 \%$ boulders, $25 \%$ cobbles $)$.

Notes: This site is located in the Coal Siding Run floodplain off of Forest Service Rd. 943. The understory consists of rhododendron, hemlock, service berry, red maple, basswood, Frasier fir, hay-scented fern, red oak, moss, lichen, and greenbrier. The midstory consists of yellow birch, red maple, beech, sugar maple, and hemlock. The water table is located at $102 \mathrm{~cm}$ (40 in) with free water at $127 \mathrm{~cm}$ (50 in). 
Profile Number: 11

Soil Description Number: FS04WV067005

Sample Date: July 14, 2004

Soil Family: Typic Fragiudepts

Area: Pocahontas Road above Richwood

Location: (GPS) NAD83 38¹4.902N 80³2.391W EPE 89ft

Natural Vegetation: Chestnut oak, white oak, red oak, red maple, tulip poplar, black birch

Soil Temp. Regime: mesic

Parent Material: Pottsville sandstone, colluvium over residuum

Physiography: Allegheny Plateau (bench)

Relief: convex

Drainage: well-drained

Elevation: $881 \mathrm{~m}(2890 \mathrm{ft})$

Slope: $20 \%$

Aspect: SE aspect

Surface stoniness: $1 \%$

Site: FS04WV067005 described and sampled by Stephanie Connolly and Cara Sponaugle $\mathbf{O}--0$ to $2.5 \mathrm{~cm}$ ( 0 to $1 \mathrm{in})$.

A -- 2.5 to $7.5 \mathrm{~cm}$ (1 to 3 in); very dark grayish brown (10YR 3/2) silt loam; moderate medium granular structure; very friable; many very fine and fine roots and few medium roots; $10 \%$ stones; clear wavy boundary.

AB -- 7.5 to $20 \mathrm{~cm}$ (3 to 8 in); dark brown (10YR 3/3) very gravelly silt loam; moderate medium granular and weak fine subangular blocky structure; very friable; many very fine to medium roots; $55 \%$ rock fragments (35\% gravel, $20 \%$ channers); clear wavy boundary. Bw1 -- 20 to $30.5 \mathrm{~cm}$ (8 to 12 in); dark yellowish brown (10YR 4/4) very gravelly loam; moderate medium subangular blocky parting to weak medium granular structure; very friable; common very fine roots and many fine and medium roots; $45 \%$ rock fragments (35\% gravels, $10 \%$ channers); clear wavy boundary.

Bw2 -- 30.5 to $51 \mathrm{~cm}$ (12 to 20 in); yellowish brown (10YR 5/6) very gravelly loam; moderate medium subangular blocky structure; friable; common fine and few medium roots; common distinct clay films on rocks; $40 \%$ rock fragments $(35 \%$ gravels, $5 \%$ cobbles); clear wavy boundary.

Bw3 -- 51 to $94 \mathrm{~cm}$ (20 to 37 in); yellowish brown (10YR 5/6) very gravelly loam; moderate coarse subangular blocky structure; friable; common distinct clay films on rock and ped faces; $50 \%$ rock fragments (40\% gravel, $10 \%$ cobble); abrupt wavy boundary. Bx1 -- 94 to $124.5 \mathrm{~cm}$ (37 to 49 in); yellowish brown (10YR 5/6) gravelly silt loam; weak coarse prismatic structure to moderate medium platy structure; firm; common distinct light brownish gray (10YR 6/2) depletions on ped faces and few distinct yellowish red (5YR 4/6) concentration streaks; common distinct clay films on rock and ped faces; 25 rock fragments (15\% gravel, $10 \%$ cobble); clear wavy boundary.

Bx2 - 124.5 to $145 \mathrm{~cm}$ (49 to 57 in); strong brown (7.5YR 5/8) gravelly silt loam; weak coarse prismatic parting to moderate medium platy structure; firm; few distinct light pinkish gray (10YR 7/2) depletions and few distinct yellowish red (5YR 4/6) 
concentrations; common distinct clay films on rock and ped faces; $15 \%$ gravel; clear wavy boundary.

C -- 145 to $152.5 \mathrm{~cm}$ (57 to $60 \mathrm{in})$; strong brown (10YR 4/6) very cobbly silt loam; massive; firm; common distinct light gray (10YR 7/1) depletions; 50\% cobbles; clear wavy boundary.

$2 \mathbf{R}$-- $152.5+\mathrm{cm}(60+\mathrm{in})$; sandstone.

Notes: This site is located below Pocahontas Road above Richwood. The understory consists of hay scented fern, greenbrier, red maple seedlings, moss, striped maple, witch hazel, red oak seedlings, sugar maple seedlings, wild yarn, chestnut oak seedlings, New York fern, black cherry seedlings, and beech regeneration. The midstory consists of beech, sugar maple, black cherry, witch hazel, black gum, and red maple. 
Profile Number: 12

Soil Description Number: FS04WV067006

Sample Date: August 20, 2004

Soil Family: Aquic Dystrudepts

Area: Morris Creek, State Road 39

Location: (GPS) NAD27 38 $15.200 \mathrm{~N} 80^{\circ} 35.530 \mathrm{~W}$ EPE $115 \mathrm{ft}$

Natural Vegetation: Sugar maple, tulip poplar, red oak, hemlock

Soil Temp. Regime: mesic

Parent Material: Pottsville sandstone/ shale, colluvium

Physiography: Allegheny Plateau (foot slope)

Relief: concave

Drainage: Somewhat poorly drained

Elevation: $670.5 \mathrm{~m}(2200 \mathrm{ft})$

Slope: $36 \%$

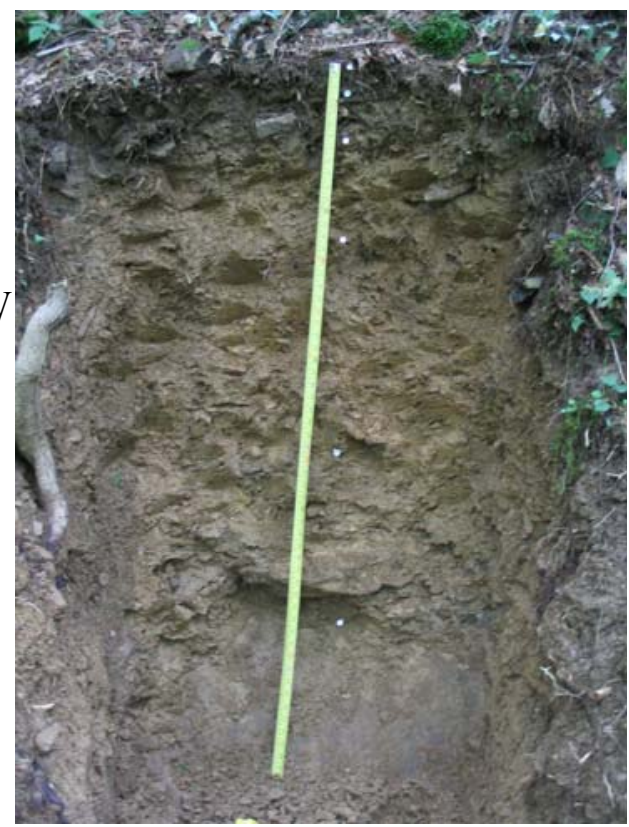

Aspect: N

Surface stoniness: $0.001 \%$

Site: FS04WV067006 described and sampled by Stephanie Connolly

Oi -- 2.5 to $0 \mathrm{~cm}$ ( 1 to 0 in).

A -- 0 to $5 \mathrm{~cm}$ (0 to 2 in); very dark brown (10YR 3/3) channery silt loam; moderate very

fine and fine granular structure; friable; common very fine and fine roots; $20 \%$ rock

fragments (5\% cobbles, $5 \%$ gravels, $10 \%$ channers); clear smooth boundary.

AB -- 5 to $15 \mathrm{~cm}$ (2 to 6 in); dark yellowish brown (10YR 4/4) channery silt loam; weak fine subangular blocky and moderate fine granular structure; friable; common very fine and many fine and medium roots; $25 \%$ rock fragments (5\% cobbles, $20 \%$ channers); clear wavy boundary.

Bw1 -- 15 to $33 \mathrm{~cm}$ (6 to 13 in); dark yellowish brown (10YR 4/6) very gravelly silt loam; moderate medium and weak fine subangular blocky structure; friable; few medium and coarse and medium fine roots; $35 \%$ rock fragments (20\% gravels, $15 \%$ channers); clear wavy boundary.

2Bw2 -- 33 to $79 \mathrm{~cm}$ (13 to 31 in); dark yellowish brown (10YR 4/6) channery loam; moderate medium and coarse subangular blocky structure; firm; common distinct light brownish gray (10YR 6/2) depletions and reddish yellow (5YR 5/8) concentrations; common fine and few medium roots; $25 \%$ rock fragments ( $5 \%$ cobbles, $20 \%$ channers); clear wavy boundary.

2Bw3 -- 79 to $114 \mathrm{~cm}$ (31 to 45 in); yellowish brown (10YR 5/6) gravelly and channery sandy clay loam; moderate medium and coarse subangular blocky structure; firm; common distinct light brownish gray (10YR 6/2) depletions and reddish yellow (5YR $5 / 8$ ) concentrations; few fine and medium roots; $40 \%$ rock fragments (20\% gravels, $20 \%$ channers); clear wavy boundary.

2BC -- 114 to $152.5+\mathrm{cm}(45$ to $60+$ in); yellowish brown $(10 \mathrm{YR} 5 / 6)$ extremely bouldery sandy clay loam; weak medium and coarse subangular blocky structure; firm; 
common distinct reddish yellow (5YR 5/8) concentrations; few fine roots around rock fragments; $90 \%$ rock fragments ( $70 \%$ boulders, $20 \%$ cobbles).

Notes: This site is located above the state road at the bridge crossing Morris Creek. The understory is made up of witch hazel, hay scented fern, sharp lobed hepatica, Christmas fern, wood nettle, trillium, and mountain magnolia. There are several springs in the surrounding area 
Profile Number: 33

Soil Description Number: FS04WV067017

Sample Date: July 29, 2004

Soil Family: Typic Dystrudepts

Area: Holcom Rd.

Location: (GPS) NAD83 38 $16.963 \mathrm{~N} 80^{\circ} 35.585 \mathrm{~W}$ EPE $43 \mathrm{ft}$

Natural Vegetation: White oak, red oak, sugar maple

Soil Temp. Regime: mesic

Parent Material: Pottsville sandstone, residuum

Physiography: Allegheny Plateau (shoulder)

Relief: convex

Drainage: well-drained

Elevation: $859.5 \mathrm{~m}(2820 \mathrm{ft})$

Slope: $2 \%$

Aspect: W aspect

Surface stoniness: $<1 \%$

Site: FS04WV067017 described and sampled by Stephanie Connolly and Cara Sponaugle $\mathbf{O}--0$ to $2.5 \mathrm{~cm}(0$ to $1 \mathrm{in})$.

A1 -- 2.5 to $7.5 \mathrm{~cm}$ (1 to 3 in); very dark brown (10YR 2/2) loam; moderate medium granular structure; very friable; many very fine to medium roots; $<5 \%$ channers; clear wavy boundary.

A2-- 7.5 to $13 \mathrm{~cm}$ (3 to 5 in); dark grayish brown (10YR 4/2) loam; moderate medium granular structure; very friable; many very fine to medium roots; $<5 \%$ channers; clear wavy boundary.

BA -- 13 to $23 \mathrm{~cm}$ (5 to 9 in); dark yellowish brown (10YR 4/4) loam; moderate medium subangular blocky parting to moderate medium granular structure; friable; many very fine to medium roots; $5 \%$ channers; clear wavy boundary.

Bw -- 23 to $43 \mathrm{~cm}$ (9 to 17 in); yellowish brown (10YR 5/6) loam; moderate medium subangular blocky structure; friable; common fine and few medium roots; $10 \%$ channers; clear wavy boundary.

BC -- 43 to $66 \mathrm{~cm}$ (17 to 26 in); yellowish brown (10YR 5/8) very channery sandy loam; weak medium subangular blocky structure; very friable; few fine roots on rock faces; $40 \%$ channers; clear wavy boundary.

C -- 66 to $76 \mathrm{~cm}$ (26 to 30 in); yellowish brown (10YR 5/8) sandy loam; massive; very friable; few fine roots on rock faces; abrupt irregular boundary; $<5 \%$ channers.

$\mathbf{R}$-- 76+ cm (30+ in); sandstone.

Notes: This site is located on the ridge off of Holcom Rd in clear cut unit near FS road 908. The understory consists of rhododendron, mountain laurel, and greenbrier. 


\section{APPENDIX C \\ SATELLITE PIT DESCRIPTIONS}

\section{Satellite Sites - Field Descriptions}

Organic layers not sampled or described in these Sites.

Site Number: 13

Soil Description Number: FS04WV025006

Sample Date: July 6, 2004

Area: Summit Lake Rec. Area below upper campground

Location: (GPS) NAD27 38 14.896N 80²6.816W EPE 30ft

Natural Vegetation: Black cherry, sugar maple, red oak

Soil Temp. Regime: frigid

Parent Material: Pottsville sandstone, colluvium

Physiography: Allegheny Plateau (side slope)

Slope: $40 \%$

Aspect: NE

Surface Stoniness: $60 \%$

A -- 0 to $7.5 \mathrm{~cm}$ (0 to 3 in); very dark gray (10YR 3/1) mucky loam; moderate medium granular structure; very friable.

BA -- 7.5 to $18 \mathrm{~cm}$ (3 to 7 in); very dark grayish brown (10YR 3/2) loam; moderate medium granular and moderate medium subangular blocky structure; friable.

Bt -- 18 to $25.5+\mathrm{cm}$ (7 to $10+$ in); dark yellowish brown (10YR 4/6) clay loam;

moderate medium subangular blocky structure; friable.

Notes: This site is located down slope of campsite 21 of the upper campground at Summit Lake. The understory consists of hay-scented fern and greenbrier.

Site Number: 14

Soil Description Number: FS04WV025007

Sample Date: July 6, 2004

Area: Summit Lake Rec. Area below upper campground

Location: (GPS) NAD27 38²14.899N 80²6.797W EPE 131ft

Natural Vegetation: Black cherry, sugar maple, red oak

Soil Temp. Regime: frigid

Parent Material: Pottsville sandstone, residuum

Physiography: Allegheny Plateau (bench)

Slope: $4 \%$

Aspect: NE

Surface Stoniness: $60 \%$

A -- 0 to $5 \mathrm{~cm}$ (0 to 2 in); black (10YR 2/1) mucky loam; moderate medium granular structure; very friable.

BA -- 5 to $15 \mathrm{~cm}$ (2 to 6 in); dark yellowish brown (10YR 4/4) loam; moderate medium granular and moderate medium subangular blocky structure; friable. 
Bw -- 15 to $25.5+\mathrm{cm}$ (6 to $10+$ in); yellowish brown (10YR 5/6) clay loam; moderate medium subangular blocky structure; friable.

Notes: This site is located down slope of campsite 21 of the upper campground at Summit Lake. The understory consists of hay-scented fern and greenbrier. There is a large rock outcrop in the slope above this site.

Site Number: 15

Soil Description Number: FS04WV025008

Sample Date: July 6, 2004

Area: Summit Lake Rec. Area upper campground

Location: (GPS) NAD27 38¹5.020N 80²6.631W EPE 82ft

Natural Vegetation: Black cherry, sugar maple, striped maple, hemlock, beech

Soil Temp. Regime: frigid

Parent Material: Pottsville sandstone, alluvial

Physiography: Allegheny Plateau (alluvial)

Slope: $8 \%$

Aspect: NE

Surface Stoniness: $<0.01 \%$

A -- 0 to $7.5 \mathrm{~cm}$ (0 to 3 in); very dark grayish brown (10YR 3/2) loam; moderate medium granular structure; very friable.

Bt -- 7.5 to $20+$ cm (3 to $8+$ in); dark yellowish brown (10YR 4/6) clay loam; moderate medium subangular blocky structure; friable.

Notes: This site is located off the trail above campsite 14 at the upper Summit Lake campground. The understory consists of hay-scented fern, greenbrier, striped maple seedlings, and beech seedlings.

Site Number: 16

Soil Description Number: FS04WV025009

Sample Date: July 6, 2004

Area: Summit Lake Rec. Area FS rd. 945

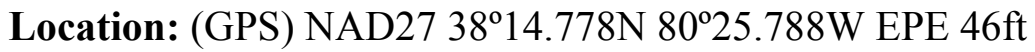

Natural Vegetation: Black cherry, sugar maple

Soil Temp. Regime: frigid

Parent Material: Pottsville sandstone, colluvium

Physiography: Allegheny Plateau (toeslope)

Slope: $18 \%$

Aspect: NE

Surface Stoniness: $<0.01 \%$

A -- 0 to $10 \mathrm{~cm}$ (0 to 4 in); very dark grayish brown (10YR 3/2) silt loam; moderate medium granular structure; very friable.

Bt -10 to $20+\mathrm{cm}$ (4 to $8+$ in); dark yellowish brown (10YR 4/6) clay loam; moderate medium subangular blocky structure; friable. 
Notes: This site is located off the landing on Forest Service road 945. The understory consists of hay-scented fern, sugar maple seedlings, and violets.

Site Number: 18

Soil Description Number: FS04WV025011

Sample Date: July 28, 2004

Area: Summit Lake - FS rd 788

Location: (GPS) NAD83 38 $14.533 \mathrm{~N} 80^{\circ} 26.113 \mathrm{~W}$ EPE $85 \mathrm{ft}$

Natural Vegetation: sugar maple, beech, black cherry

Soil Temp. Regime: frigid

Parent Material: Pottsville sandstone, colluvium

Physiography: Allegheny Plateau (shoulder)

Slope: $14 \%$

Aspect: E

Surface Stoniness: $<0.01 \%$

A -- 0 to $5 \mathrm{~cm}$ ( 0 to 2 in); very dark grayish brown (10YR 3/2) loam; moderate medium granular structure; very friable.

BA -- 5 to $20 \mathrm{~cm}$ (2 to 8 in); dark yellowish brown (10YR 4/4) loam; moderate medium granular and moderate medium subangular blocky structure; friable.

Bt -- 20 to $30.5+\mathrm{cm}(8$ to $12+$ in); yellowish brown (10YR 5/6) clay loam; moderate medium subangular blocky structure; friable.

Notes: This site is located off of Forest Service Road 788. The understory consists of hay-scented fern, forest grasses, striped maple, and sugar maple seedlings.

Site Number: 19

Soil Description Number: FS04WV025012

Sample Date: July 7, 2004

Area: Summit Lake Rec. Area above lake

Location: (GPS) NAD27 38 $15.523 \mathrm{~N} 80^{\circ} 26.105 \mathrm{~W}$ EPE 52ft

Natural Vegetation: Black cherry, sugar maple, striped maple

Soil Temp. Regime: frigid

Parent Material: Pottsville sandstone, residuum

Physiography: Allegheny Plateau (bench)

Slope: $5 \%$

Aspect: NE

Surface Stoniness: $<0.01 \%$

A -- 0 to $13 \mathrm{~cm}$ (0 to 5 in); very dark grayish brown (10YR 3/2) mucky loam; moderate medium granular structure; very friable.

Bw -- 13 to $23+\mathrm{cm}$ (5 to 9+ in); dark yellowish brown (10YR 4/6) clay loam; moderate medium subangular blocky structure; friable. 
Notes: This site is located above the lake off of Forest Service road 944. The understory consists of hay-scented fern. There is a "rock city" on the bench within view of the sample site.

Site Number: 20

Soil Description Number: FS04WV025013

Sample Date: July 7, 2004

Area: Summit Lake Rec. Area FS rd 99

Location: (GPS) NAD27 38²15.344N 80²5.696W EPE 72ft

Natural Vegetation: Black cherry, striped maple, hemlock, beech

Soil Temp. Regime: frigid

Parent Material: Pottsville sandstone, residuum

Physiography: Allegheny Plateau (ridge)

Slope: $14 \%$

Aspect: NE

Surface Stoniness: $<0.01 \%$

A -- 0 to $5 \mathrm{~cm}$ ( 0 to 2 in); very dark brown (10YR 2/2) loam; moderate medium granular structure; very friable.

BA -- 5 to $10 \mathrm{~cm}$ (2 to 4 in); dark brown (10YR 4/3) loam; moderate medium granular and weak medium subangular blocky structure; friable.

Bt -- 10 to $23+$ cm (4 to 9+ in); dark yellowish brown (10YR 4/6) clay loam; moderate medium subangular blocky structure; friable.

Notes: This site is located on the ridge above Forest Service road 99. The understory consists of hay-scented fern, greenbrier, and cucumber root. There are several large boulders in the area.

Site Number: 21

Soil Description Number: FS04WV025014

Sample Date: July 7, 2004

Area: Summit Lake - FS rd 788

Location: (GPS) NAD27 38014.545N 80²5.987W EPE 102ft

Natural Vegetation: Sugar maple, hemlock, beech

Soil Temp. Regime: frigid

Parent Material: Pottsville sandstone, colluvium

Physiography: Allegheny Plateau (midslope)

Slope: $24 \%$

Aspect: E

Surface Stoniness: $<0.01 \%$

A -- 0 to $7.5 \mathrm{~cm}$ (0 to 3 in); very dark grayish brown (10YR 3/2) loam; moderate medium granular structure; very friable.

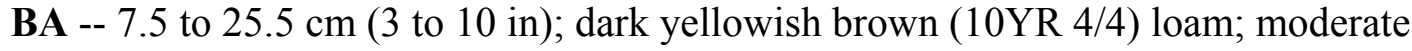
medium subangular blocky parting to moderate medium granular structure; friable. 
Bt -- 25.5 to $36+\mathrm{cm}(10$ to $14+$ in); yellowish brown (10YR 5/6) clay loam; moderate medium subangular blocky structure; friable.

Notes: This site is located below Forest Service road 788. The understory consists of hay-scented fern, violets, and forest grasses.

Site Number: 22

Soil Description Number: FS04WV025015

Sample Date: July 7, 2004

Area: Summit Lake Rec. Area FS rd 786

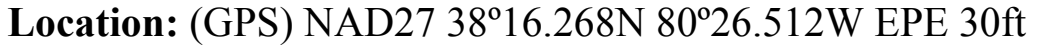

Natural Vegetation: Black cherry, sugar maple, striped maple, basswood

Soil Temp. Regime: frigid

Parent Material: Pottsville sandstone, colluvium

Physiography: Allegheny Plateau (shoulder)

Slope: $28 \%$

Aspect: E

Surface Stoniness: $<0.01 \%$

A -- 0 to $10 \mathrm{~cm}$ (0 to 4 in); very dark grayish brown (10YR 3/2) mucky loam; moderate medium granular structure; very friable.

Bt -- 10 to $25.5+\mathrm{cm}$ (4 to $10+$ in); yellowish brown (10YR 5/6) clay loam; moderate medium subangular blocky structure; friable.

Notes: This site is located below Forest Service road 786. The understory consists of hay-scented fern, forest grasses, and cherry seedlings.

Site Number: 24

Soil Description Number: FS04WV067008

Sample Date: July 27, 2004

Area: Holcom Rd before bridge

Location: (GPS) NAD83 38 $15.208 \mathrm{~N} \mathrm{80} 35.535 \mathrm{~W}$ EPE 69ft

Natural Vegetation: sugar maple, red maple, yellow poplar, beech

Soil Temp. Regime: mesic

Parent Material: Pottsville sandstone, colluvium

Physiography: Allegheny Plateau (toeslope)

Slope: $28 \%$

Aspect: N

Surface Stoniness: $<0.01 \%$

A -- 0 to $13 \mathrm{~cm}$ (0 to 5 in); very dark grayish brown (10YR 3/2) loam; moderate medium granular structure; very friable.

BA -- 13 to 28 cm (5 to 11 in); dark yellowish brown (10YR 4/4) loam; moderate medium subangular blocky parting to moderate medium granular structure; friable. Bw -- 28 to $38+\mathrm{cm}$ (11 to $15+$ in); yellowish brown (10YR 5/6) clay loam; moderate medium subangular blocky structure; friable. 
Notes: This site is located on the Holcom side of the project area. The understory consists of greenbrier, hay-scented fern, and maple seedlings, and violets.

Site Number: 25

Soil Description Number: FS04WV067009

Sample Date: July 27, 2004

Area: Holcom Rd above bridge

Location: (GPS) NAD83 38015.317N 80³5.530W EPE 121ft

Natural Vegetation: sugar maple, red maple, birch, beech, cucumber magnolia, white oak, red oak

Soil Temp. Regime: mesic

Parent Material: Pottsville sandstone, alluvium

Physiography: Allegheny Plateau (floodplain)

Slope: $2 \%$

Aspect: N

Surface Stoniness: $<0.01 \%$

A -- 0 to $7.5 \mathrm{~cm}$ (0 to 3 in); very dark grayish brown (10YR 3/2) sandy loam; weak medium granular structure; very friable.

BA -- 7.5 to $20 \mathrm{~cm}$ (3 to 8 in); dark brown (10YR 4/3) sandy loam; weak medium subangular blocky and moderate medium granular structure; very friable.

Bg -- 20 to 33+ cm (8 to 13+ in); dark gray (10YR 3/1) sandy loam; weak medium subangular blocky structure; very friable.

Notes: This site is located above the bridge on Holcom Rd. in the Morris Creek floodplain. The understory consists of greenbrier, NY fern, rhododendron, mountain laurel, forest grasses, and maple, beech, and oak seedlings. Other colors found in the Bwg horizon are 10YR 4/1, 10YR 4/4, and 5YR 4/6.

Site Number: 26

Soil Description Number: FS04WV067010

Sample Date: July 27, 2004

Area: Holcom Rd.

Location: (GPS) NAD83 38 $15.257 \mathrm{~N} \mathrm{80} 35.219 \mathrm{~W}$ EPE 43ft

Natural Vegetation: sugar maple, beech, cucumber magnolia, white oak, red oak

Soil Temp. Regime: mesic

Parent Material: Pottsville sandstone, colluvium

Physiography: Allegheny Plateau (midslope)

Slope: 28\%

Aspect: S

Surface Stoniness: $<0.01 \%$

A -- 0 to $10 \mathrm{~cm}$ (0 to 4 in); very dark grayish brown (10YR 3/2) loam; moderate medium granular structure; very friable. 
BA -- 10 to $25.5 \mathrm{~cm}$ (4 to 10 in); dark yellowish brown (10YR 4/4) loam; weak medium subangular blocky structure; friable.

Bw -- 25.5 to $38+\mathrm{cm}$ (10 to $15+$ in); yellowish brown (10YR 5/6) clay loam; moderate medium subangular blocky structure; friable.

Notes: This site is located above Holcom road. The understory consists of witch hazel, NY fern, and maple and oak seedlings.

Site Number: 27

Soil Description Number: FS04WV067011

Sample Date: July 27, 2004

Area: Holcom Rd - headwaters of Morris Creek

Location: (GPS) NAD83 38 $15.382 \mathrm{~N} 80^{\circ} 34.174 \mathrm{~W}$ EPE $72 \mathrm{ft}$

Natural Vegetation: sugar maple, white oak, red oak, fire cherry

Soil Temp. Regime: mesic

Parent Material: Pottsville sandstone, alluvium

Physiography: Allegheny Plateau (floodplain)

Slope: $13 \%$

Aspect: SE

Surface Stoniness: $<0.01 \%$

BA -- 0 to $13 \mathrm{~cm}$ (0 to 5 in); dark yellowish brown (10YR 4/4) sandy loam; weak medium subangular blocky structure; friable.

Bw -- 13 to $23+\mathrm{cm}$ (5 to $9+$ in); yellowish brown (10YR 5/6) sandy loam; moderate medium subangular blocky structure; friable.

Notes: This site is located off of Holcom road before the stone bridge in the headwaters of Morris Creek. The understory consists of NY fern, violets, forest grasses, trillium, and rhododendron.

Site Number: 28

Soil Description Number: FS04WV067012

Sample Date: July 27, 2004

Area: Holcom Rd.

Location: (GPS) NAD83 38¹6.365N 80³3.905W EPE 62ft

Natural Vegetation: sugar maple, red maple, hickory, red oak

Soil Temp. Regime: mesic

Parent Material: Pottsville sandstone, residuum

Physiography: Allegheny Plateau (ridge)

Slope: $1 \%$

Aspect: SW

Surface Stoniness: $<0.01 \%$

A -- 0 to $7.5 \mathrm{~cm}$ (0 to 3 in); very dark grayish brown (10YR 3/2) loam; moderate medium granular structure; very friable. 
BA -- 7.5 to $23 \mathrm{~cm}$ (3 to 9 in); dark yellowish brown (10YR 4/4) loam; moderate medium granular and moderate medium subangular blocky structure; friable.

Bw -- 23 to $35.5+\mathrm{cm}$ (9 to 14+ in); yellowish brown (10YR 5/8) clay loam; moderate medium subangular blocky structure; friable.

Notes: This site is located off of Holcom Rd across from intersection with Pocahontas $\mathrm{Rd}$. The understory consists of greenbrier, witch hazel, and maple seedlings.

Site Number: 29

Soil Description Number: FS04WV067013

Sample Date: July 27, 2004

Area: Holcom Rd

Location: (GPS) NAD83 38²17.148N 80³5.560W EPE 141ft

Natural Vegetation: sugar maple, red maple, beech, white oak, red oak

Soil Temp. Regime: mesic

Parent Material: Pottsville sandstone, colluvium

Physiography: Allegheny Plateau (midslope)

Slope: $33 \%$

Aspect: NE

Surface Stoniness: $<0.01 \%$

A -- 0 to $15 \mathrm{~cm}$ (0 to 6 in); very dark grayish brown (10YR 3/2) loam; moderate medium granular structure; very friable.

BA -- 15 to $25.5 \mathrm{~cm}$ (6 to 10 in); dark yellowish brown (10YR 4/6) loam; moderate medium subangular blocky and moderate medium granular structure; friable.

Bw -- 25.5 to $41 \mathrm{~cm}$ (10 to $16+$ in); yellowish brown (10YR 5/8) clay loam; moderate medium subangular blocky structure; friable.

Notes: This site is located off of Holcom $\mathrm{Rd}$. on the right side. The understory consists of striped maple, hay-scented fern, and maple and oak seedlings.

Site Number: 30

Soil Description Number: FS04WV067014

Sample Date: July 27, 2004

Area: Holcom Rd

Location: (GPS) NAD83 38¹6.556N 80³4.643W EPE 112ft

Natural Vegetation: sugar maple, red maple, yellow poplar, white oak, red oak

Soil Temp. Regime: mesic

Parent Material: Pottsville sandstone, residuum

Physiography: Allegheny Plateau (bench)

Slope: $8 \%$

Aspect: SE

Surface Stoniness: $<0.01 \%$

A -- 0 to $5 \mathrm{~cm}$ (0 to 2 in); very dark grayish brown (10YR 3/2) silt loam; moderate medium granular structure; very friable. 
BA -- 5 to $15 \mathrm{~cm}$ (2 to 6 in); dark yellowish brown (10YR 4/4) loam; moderate medium granular and moderate medium subangular blocky structure; friable.

Bw -- 15 to $25.5+\mathrm{cm}$ (6 to $10+$ in); brownish yellow (10YR 6/8) loam; moderate medium subangular blocky structure; friable.

Notes: This site is located off of Holcom Rd. The understory consists of greenbrier, hayscented fern, striped maple, and maple and oak seedlings.

Site Number: 31

Soil Description Number: FS04WV067015

Sample Date: July 27, 2004

Area: County Rt. 74 above Richwood

Location: (GPS) NAD83 38 $14.604 \mathrm{~N} \mathrm{80} 32.277 \mathrm{~W}$ EPE 66ft

Natural Vegetation: sugar maple, basswood, hickory, white oak, red oak

Soil Temp. Regime: frigid

Parent Material: Pottsville sandstone, colluvium

Physiography: Allegheny Plateau (shoulder)

Slope: $9 \%$

Aspect: NNE

Surface Stoniness: $<0.01 \%$

A -- 0 to $13 \mathrm{~cm}$ (0 to 5 in); very dark brown (10YR 2/2) silt loam; moderate medium granular structure; very friable.

BA -- 13 to $33 \mathrm{~cm}$ (5 to 13 in); dark brown (10YR 3/3) loam; weak medium subangular blocky parting to moderate medium granular structure; friable.

Bw -- 33 to $43+$ cm (13 to $17+$ in); dark yellowish brown (10YR 4/4) clay loam;

moderate medium subangular blocky structure; friable.

Notes: This site is located off of Holcom Rd. The understory consists of hat-scented fern, poison ivy, bloodroot, and maple, beech, and oak seedlings.

Site Number: 32

Soil Description Number: FS04WV067016

Sample Date: July 27, 2004

Area: County Rt. 74 above Richwood

Location: (GPS) NAD83 38014.521N 80³2.376W EPE 143ft

Natural Vegetation: sugar maple, beech, white oak, red oak

Soil Temp. Regime: mesic

Parent Material: Pottsville sandstone, residuum

Physiography: Allegheny Plateau (ridge)

Slope: $<1 \%$

Aspect: NNE

Surface Stoniness: $<0.01 \%$

A -- 0 to $10 \mathrm{~cm}$ (0 to 4 in); very dark brown (10YR 2/2) loam; moderate medium granular structure; very friable. 
BA -- 10 to $23 \mathrm{~cm}$ (4 to 9 in); dark yellowish brown (10YR 4/4) loam; weak medium subangular blocky parting to moderate medium granular structure; friable.

Bt -- 23 to $30.5+$ cm (9 to $12+$ in); yellowish brown (10YR 5/8) loam; moderate medium subangular blocky structure; friable.

Notes: This site is located off of County Rt. 74. The understory consists of greenbrier, hay-scented fern, witch hazel, striped maple, and maple and oak seedlings.

Site Number: 34

Soil Description Number: FS04WV025016

Sample Date: July 28, 2004

Area: Summit Lake - in floodplain at FS rd 944 gate

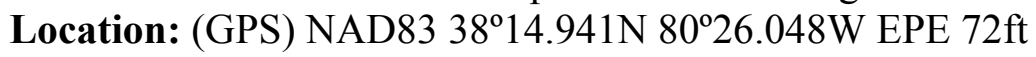

Natural Vegetation: birch, beech, cucumber magnolia, hemlock

Soil Temp. Regime: frigid

Parent Material: Pottsville sandstone, alluvium

Physiography: Allegheny Plateau (floodplain)

Slope: $4 \%$

Aspect: NW

Surface Stoniness: $<0.01 \%$

A1 -- 0 to $7.5 \mathrm{~cm}$ (0 to 3 in); very dark brown (10YR 2/2) loam; moderate medium granular structure; very friable.

A2 -- 7.5 to $15 \mathrm{~cm}$ (3 to 6 in); dark grayish brown (10YR 3/2) loam; moderate medium granular structure; very friable.

Bw -- 15 to $28+$ cm (6 to $11+$ in); yellowish brown (10YR 5/8) clay loam; moderate medium subangular blocky structure; friable.

Notes: This site is located in the floodplain at Forest Service Road 944 gate. The understory consists of hay-scented fern, forest grasses, ground pine, trillium, and violets.

Site Number: 35

Soil Description Number: FS04WV025017

Sample Date: July 28, 2004

Area: Summit Lake - FS rd 944

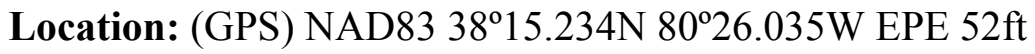

Natural Vegetation: sugar maple, beech, black cherry

Soil Temp. Regime: frigid

Parent Material: Pottsville sandstone, colluvium

Physiography: Allegheny Plateau (midslope)

Slope: $23 \%$

Aspect: NW

Surface Stoniness: $<0.01 \%$

A -- 0 to $7.5 \mathrm{~cm}$ (0 to 3 in); very dark grayish brown (10YR 3/2) loam; moderate medium granular structure; very friable. 
BA -- 7.5 to $23 \mathrm{~cm}$ (3 to 9 in); dark yellowish brown (10YR 4/4) loam; moderate medium granular and moderate medium subangular blocky structure; friable.

Bt -- 23 to $33+\mathrm{cm}$ (9 to $13+$ in); yellowish brown (10YR 4/6) clay loam; moderate medium subangular blocky structure; friable.

Notes: This site is located off of Forest Service Road 944. The understory consists of hay-scented fern, striped maple, and beech seedlings.

Site Number: 36

Soil Description Number: FS04WV025018

Sample Date: July 28, 2004

Area: Summit Lake - FS rd 944

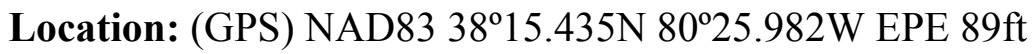

Natural Vegetation: red maple, beech, hemlock

Soil Temp. Regime: frigid

Parent Material: Pottsville sandstone, colluvium

Physiography: Allegheny Plateau (toeslope)

Slope: $14 \%$

Aspect: NW

Surface Stoniness: $<0.01 \%$

A -- 0 to $10 \mathrm{~cm}$ (0 to 4 in); very dark grayish brown (10YR 3/2) loam; moderate medium granular structure; very friable.

Bw -- 10 to $25.5+\mathrm{cm}$ (4 to $10+$ in); yellowish brown (10YR 5/8) clay loam; moderate medium subangular blocky structure; friable.

Notes: This site is located off of Forest Service Road 944. The understory consists of hay-scented fern, striped maple, and beech seedlings.

Site Number: 38

Soil Description Number: FS04WV067018

Sample Date: July 26, 2004

Area: Holcom Rd. end of FS Rd. 908

Location: (GPS) NAD83 38²16.526N 80³6.146W EPE 85ft

Natural Vegetation: Cucumber magnolia, yellow poplar, beech, sugar maple, red oak

Soil Temp. Regime: mesic

Parent Material: Pottsville sandstone, colluvium

Physiography: Allegheny Plateau (toeslope)

Slope: $14 \%$

Aspect: NW

Surface Stoniness: $<0.01 \%$

A -- 0 to $7.5 \mathrm{~cm}$ (0 to 3 in); very dark brown (10YR 2/2) loam; moderate medium granular structure; very friable.

BA -- 7.5 to $20 \mathrm{~cm}$ (3 to 8 in); dark yellowish brown (10YR 3/4) loam; moderate medium subangular blocky parting to moderate medium granular structure; friable. 
Bt -- 20 to $30.5 \mathrm{~cm}$ (8 to $12+$ in); yellowish brown (10YR 5/6) loam; moderate medium subangular blocky structure; friable.

Notes: This site is located beyond the final log landing on Forest Service road 908. The understory consists of hay-scented fern, greenbrier, sugar maple seedlings, magnolia seedlings, and violets.

Site Number: 39

Soil Description Number: FS04WV067019

Sample Date: July 26, 2004

Area: Holcom Rd. FS Rd. 908

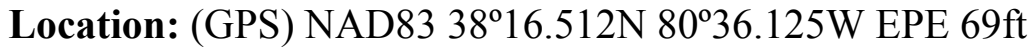

Natural Vegetation: Cucumber magnolia, yellow poplar, beech, sugar maple, red oak

Soil Temp. Regime: mesic

Parent Material: Pottsville sandstone, residuum

Physiography: Allegheny Plateau (bench)

Slope: $12 \%$

Aspect: NW

Surface Stoniness: $<0.01 \%$

A -- 0 to $15 \mathrm{~cm}$ (0 to 6 in); very dark grayish brown (10YR 3/2) silt loam; moderate medium granular structure; very friable.

BA -- 15 to $33 \mathrm{~cm}$ (6 to 13 in); dark yellowish brown (10YR 4/4) loam; moderate medium subangular blocky and moderate medium granular structure; friable.

Bw -- 33 to $46+\mathrm{cm}$ (13 to $18+$ in); yellowish brown (10YR 5/6) clay loam; moderate medium subangular blocky structure; friable.

Notes: This site is located off of Forest Service road 908. The understory consists of hay-scented fern, cucumber root, striped maple, sugar maple seedlings, red oak seedlings, and violets.

Site Number: 40

Soil Description Number: FS04WV067020

Sample Date: July 26, 2004

Area: Holcom Rd. FS Rd. 908

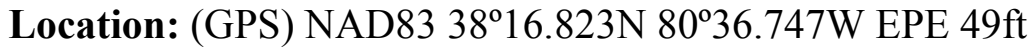

Natural Vegetation: red maple, white oak, red oak

Soil Temp. Regime: mesic

Parent Material: Pottsville sandstone, colluvium

Physiography: Allegheny Plateau (shoulder)

Slope: $14 \%$

Aspect: SW

Surface Stoniness: $<0.01 \%$

A -- 0 to $10 \mathrm{~cm}$ (0 to 4 in); black (10YR 2/1) loam; moderate medium granular structure; very friable. 
BA -- 10 to $20 \mathrm{~cm}$ (4 to 8 in); dark yellowish brown (10YR 3/4) sandy loam; moderate medium subangular blocky and moderate medium granular structure; friable.

Bt -- 20 to $33+\mathrm{cm}$ ( 8 to $13+$ in); dark yellowish brown (10YR 4/4) sandy loam; moderate medium subangular blocky structure; friable.

Notes: This site is located off of Forest Service road 908. The understory consists of greenbrier, mountain laurel, rhododendron, tea berry, oak seedlings, and violets.

Site Number: 41

Soil Description Number: FS04WV067021

Sample Date: July 26, 2004

Area: Holcom Rd. FS Rd. 908

Location: (GPS) NAD83 38¹6.982N 80³6.488W EPE 49ft

Natural Vegetation: sugar maple, basswood, white oak, red oak

Soil Temp. Regime: mesic

Parent Material: Pottsville sandstone, residuum

Physiography: Allegheny Plateau (ridge)

Slope: $3 \%$

Aspect: SE

Surface Stoniness: $<0.01 \%$

A -- 0 to $7.5 \mathrm{~cm}$ (0 to 3 in); very dark gray (10YR 3/1) loam; moderate medium granular structure; very friable.

BA -- 75 to $20 \mathrm{~cm}$ (3 to 8 in); dark yellowish brown (10YR 4/4) loam; moderate medium subangular blocky structure; friable.

Bw -- 20 to $28+$ cm (8 to $11+$ in); yellowish brown $(10$ YR 5/6) sandy loam; moderate medium subangular blocky structure; friable.

Notes: This site is located off of Forest Service road 908. The understory consists of greenbrier, striped maple, and sugar maple seedlings.

Site Number: 42

Soil Description Number: FS04WV067022

Sample Date: July 26, 2004

Area: Holcom Rd.

Location: (GPS) NAD83 38 $15.737 \mathrm{~N} \mathrm{80} 33.722 \mathrm{~W}$ EPE 49ft

Natural Vegetation: sugar maple, white oak, yellow poplar

Soil Temp. Regime: mesic

Parent Material: Pottsville sandstone, colluvium

Physiography: Allegheny Plateau (shoulder)

Slope: $24 \%$

Aspect: WNW

Surface Stoniness: $<0.01 \%$

A1 -- 0 to $13 \mathrm{~cm}$ (0 to 5 in); black (10YR 2/1) sandy loam; moderate medium granular structure; very friable. 
A2 -- 13 to $33 \mathrm{~cm}$ (5 to 13 in); very dark gray (10YR 3/1) sandy loam; moderate medium granular structure; very friable.

AB -- 33 to $43+$ cm (13 to $17+$ in); dark grayish brown (10YR 3/2) sandy loam; moderate medium subangular blocky and moderate medium granular structure; friable.

Notes: This site is located off Holcom road above the rock wall. The understory consists of hay-scented fern, NY fern, striped maple, and oak seedlings.

Site Number: 43

Soil Description Number: FS04WV067023

Sample Date: July 26, 2004

Area: Pocahontas Rd. Holcom side

Location: (GPS) NAD83 38²15.617N 80³3.583W EPE 75ft

Natural Vegetation: sugar maple, red maple, yellow poplar, white oak, red oak

Soil Temp. Regime: mesic

Parent Material: Pottsville sandstone, residuum

Physiography: Allegheny Plateau (ridge)

Slope: $3 \%$

Aspect: NW

Surface Stoniness: $<0.01 \%$

A -- 0 to $7.5 \mathrm{~cm}$ (0 to 3 in); very dark grayish brown (10YR 3/2) loam; moderate medium granular structure; very friable.

BA -- 7.5 to $15 \mathrm{~cm}$ (3 to 6 in); dark brown (10YR 4/3) loam; weak medium subangular blocky structure; friable.

Bw -- 15 to $30.5+\mathrm{cm}$ (6 to $12+$ in); yellowish brown (10YR 5/6) clay loam; moderate medium subangular blocky structure; friable.

Notes: This site is located off of Pocahontas road - Holcom side. The understory consists of greenbrier, NY fern, and maple and oak seedlings.

Site Number: 44

Soil Description Number: FS04WV067024

Sample Date: July 26, 2004

Area: Pocahontas road - Holcom side

Location: (GPS) NAD83 38¹5.021N 80³2.397W EPE 52ft

Natural Vegetation: sugar maple, beech, white oak, red maple

Soil Temp. Regime: mesic

Parent Material: Pottsville sandstone, colluvium

Physiography: Allegheny Plateau (midslope)

Slope: $13 \%$

Aspect: N

Surface Stoniness: $<0.01 \%$

BA -- 0 to $7.5 \mathrm{~cm}$ (0 to 3 in); dark brown (10YR 4/3) loam; moderate medium granular and weak medium subangular blocky structure; very friable. 
Bt -- 7.5 to $20+$ cm (3 to 8+ in); yellowish brown (10YR 5/4) clay loam; moderate medium subangular blocky structure; friable.

Notes: This site is located off of Pocahontas road - Holcom side. The understory consists of greenbrier, cucumber root, blood root, and beech seedlings.

Site Number: 45

Soil Description Number: FS04WV025020

Sample Date: July 28, 2004

Area: Summit Lake - FS rd 77

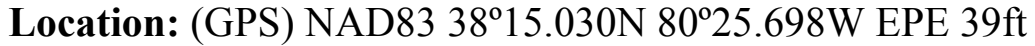

Natural Vegetation: sugar maple, beech, black cherry

Soil Temp. Regime: frigid

Parent Material: Pottsville sandstone, residuum

Physiography: Allegheny Plateau (bench)

Slope: $8 \%$

Aspect: NNW

Surface Stoniness: $<0.01 \%$

A -- 0 to $7.5 \mathrm{~cm}$ (0 to 3 in); dark brown (10YR 3/3) loam; moderate medium granular structure; very friable.

BA -- 7.5 to $20 \mathrm{~cm}$ (3 to 8 in); dark yellowish brown (10YR 4/4) loam; moderate medium granular and weak medium subangular blocky structure; friable.

Bt -- 20 to $30.5+\mathrm{cm}$ (8 to $12+$ in); yellowish brown (10YR 5/6) clay loam; moderate medium subangular blocky structure; friable.

Notes: This site is located off of Forest Service Road 77. The understory consists of hayscented fern, forest grasses, striped maple, and violets.

Site Number: 46

Soil Description Number: FS04WV025021

Sample Date: July 28, 2004

Area: Summit Lake - FS rd 786

Location: (GPS) NAD83 38 $16.004 \mathrm{~N} 80^{\circ} 26.452 \mathrm{~W}$ EPE 49ft

Natural Vegetation: sugar maple, red maple, black cherry

Soil Temp. Regime: frigid

Parent Material: Pottsville sandstone, colluvium

Physiography: Allegheny Plateau (midslope)

Slope: $26 \%$

Aspect: NW

Surface Stoniness: $<0.01 \%$

A -- 0 to $5 \mathrm{~cm}$ (0 to 2 in); dark brown (10YR 3/3) loam; moderate medium granular structure; very friable.

BA -- 5 to $15 \mathrm{~cm}$ (2 to 6 in); dark yellowish brown (10YR 4/6) loam; weak medium subangular blocky structure; friable. 
Bw -- 15 to $25.5 \mathrm{~cm}$ (6 to 10+ in); yellowish brown (10YR 5/6) clay loam; moderate medium subangular blocky structure; friable.

Notes: This site is located off of Forest Service Road 786. The understory consists of hay-scented fern, violets, striped maple, and red maple seedlings.

Site Number: 47

Soil Description Number: FS04WV101002

Sample Date: July 28, 2004

Area: Summit Lake - FS rd 99 Pocahontas Rd

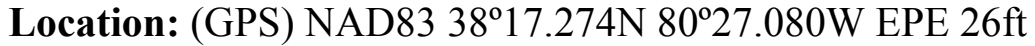

Natural Vegetation: sugar maple, beech, black cherry

Soil Temp. Regime: frigid

Parent Material: Pottsville sandstone, residuum

Physiography: Allegheny Plateau (bench)

Slope: $3 \%$

Aspect: N

Surface Stoniness: $<0.01 \%$

A -- 0 to $13 \mathrm{~cm}$ (0 to $5 \mathrm{in})$; very dark grayish brown (10YR 3/2) loam; moderate medium granular structure; very friable.

BA -- 13 to $30.5 \mathrm{~cm}$ (5 to 12 in); dark yellowish brown (10YR 4/4) loam; moderate medium granular and weak medium subangular blocky structure; friable.

Bt -- 30.5 to $40.5+\mathrm{cm}$ (12 to $16+$ in); dark yellowish brown (10YR 4/4) clay loam; moderate medium subangular blocky structure; friable.

Notes: This site is located off of Forest Service Road 99. The understory consists of hayscented fern, forest grasses, and sugar maple seedlings.

Site Number: 48

Soil Description Number: FS04WV067025

Sample Date: August 1, 2004

Area: Holcom Rd. - at intersection with FS rd 908

Location: (GPS) NAD83 38017.180N 80³5.660W EPE 112ft

Natural Vegetation: hemlock, white oak, beech

Soil Temp. Regime: mesic

Parent Material: Pottsville sandstone, residuum

Physiography: Allegheny Plateau (ridge)

Slope: $<1 \%$

Aspect: NW

Surface Stoniness: $<0.01 \%$

A -- 0 to $7.5 \mathrm{~cm}$ (0 to 3 in); very dark grayish brown (10YR 3/2) loam; moderate medium granular structure; very friable.

BA -- (7.5 to $18 \mathrm{~cm} 3$ to 7 in); dark yellowish brown (10YR 4/6) sandy loam; weak medium subangular blocky structure; friable. 
Bw -- 18 to $25.5+\mathrm{cm}$ (7 to $10+$ in); yellowish brown (10YR 5/6) sandy loam; moderate medium subangular blocky structure; friable.

Notes: This site is located off of Holcom Rd at the intersection with FS road 908. The understory consists of hay-scented fern, greenbrier, and red maple, white oak, and beech seedlings.

Site Number: 49

Soil Description Number: FS04WV067026

Sample Date: August 1, 2004

Area: Holcom Rd.

Location: (GPS) NAD83 38 $15.459 \mathrm{~N} \mathrm{80} 33.297 \mathrm{~W}$ EPE 39ft

Natural Vegetation: sugar maple, beech, red maple, red oak

Soil Temp. Regime: mesic

Parent Material: Pottsville sandstone, residuum

Physiography: Allegheny Plateau (ridge)

Slope: $<1 \%$

Aspect: NW

Surface Stoniness: $<0.01 \%$

A -- 0 to $13 \mathrm{~cm}$ (0 to $5 \mathrm{in})$; very dark brown (10YR 2/2) loam; moderate medium granular structure; very friable.

BA -- 13 to $28 \mathrm{~cm}$ (5 to 11 in); dark yellowish brown (10YR 4/3) loam; moderate medium subangular blocky structure; friable.

Bw -- 28 to $38+\mathrm{cm}$ (11 to $15+$ in); yellowish brown (10YR 5/6) clay loam; moderate medium subangular blocky structure; friable.

Notes: This site is located off of Holcom Road. The understory consists of greenbrier, oak seedlings, and red maple seedlings.

Site Number: 50

Soil Description Number: FS04WV067027

Sample Date: August 1, 2004

Area: Holcom Rd.

Location: (GPS) NAD83 38 $16.579 \mathrm{~N} 80^{\circ} 34.575 \mathrm{~W}$ EPE $43 \mathrm{ft}$

Natural Vegetation: sugar maple, red maple, red maple, red oak, beech, chestnut

Soil Temp. Regime: mesic

Parent Material: Pottsville sandstone, colluvium

Physiography: Allegheny Plateau (bench)

Slope: $17 \%$

Aspect: NNW

Surface Stoniness: $<0.01 \%$

A -- 0 to $5 \mathrm{~cm}$ (0 to 2 in); very dark grayish brown (10YR 3/2) loam; moderate medium granular structure; very friable. 
BA -- 5 to $15 \mathrm{~cm}$ (2 to 6 in); dark yellowish brown (10YR 4/4) loam; moderate medium granular and moderate medium subangular blocky structure; friable.

Bt -- 15 to $28+\mathrm{cm}$ (6 to $11+$ in); yellowish brown (10YR 5/8) loam; moderate medium subangular blocky structure; friable.

Notes: This site is located off of Holcom Road. The understory consists of greenbrier, hay-scented fern, white oak seedlings, and red oak seedlings.

Site Number: 51

Soil Description Number: FS04WV067028

Sample Date: August 1, 2004

Area: Pocahontas Rd - Holcom

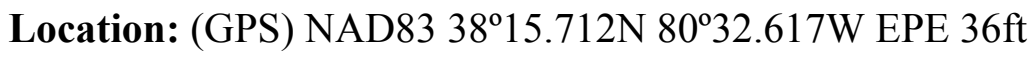

Natural Vegetation: sugar maple, beech

Soil Temp. Regime: mesic

Parent Material: Pottsville sandstone, colluvium

Physiography: Allegheny Plateau (midslope)

Slope: $14 \%$

Aspect: NE

Surface Stoniness: $<0.01 \%$

A1 -- 0 to $5 \mathrm{~cm}$ (0 to 2 in); very dark grayish brown (10YR 3/2) loam; moderate medium granular structure; very friable.

A2 -- 5 to $20 \mathrm{~cm}$ (2 to 8 in); dark brown (10YR 3/3) loam; moderate medium granular structure; very friable.

Bw -- 20 to $30.5+\mathrm{cm}$ (8 to $12+$ in); dark yellowish brown (10YR 4/6) loam; moderate medium subangular blocky structure; friable.

Notes: This site is located off of Pocahontas Road above Holcom. The understory consists of hay-scented fern, cucumber root, beech seedlings, red oak seedlings, and sugar maple seedlings.

Site Number: 52

Soil Description Number: FS04WV067029

Sample Date: August 1, 2004

Area: Pocahontas Rd - Holcom

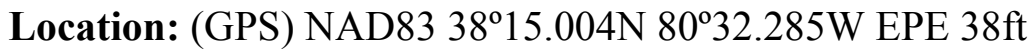

Natural Vegetation: sugar maple, beech, red oak

Soil Temp. Regime: mesic

Parent Material: Pottsville sandstone, colluvium

Physiography: Allegheny Plateau (midslope)

Slope: $18 \%$

Aspect: W

Surface Stoniness: $<0.01 \%$ 
A -- 0 to $2.5 \mathrm{~cm}$ (0 to 1 in); dark brown (10YR 3/3) loam; moderate medium granular structure; very friable.

BA -- 2.5 to $18 \mathrm{~cm}$ (1 to 7 in); dark yellowish brown (10YR 4/4) loam; moderate medium subangular blocky structure; friable.

Bw -- 18 to $30.5+$ cm (7 to $12+$ in); yellowish brown (10YR 5/6) clay loam; moderate medium subangular blocky structure; friable.

Notes: This site is located off of Pocahontas Road above Holcom. The understory consists of greenbrier, oak seedlings, maple seedlings, hay-scented fern, mountain laurel, and rhododendron.

Site Number: 53

Soil Description Number: FS04WV067030

Sample Date: August 1, 2004

Area: Pocahontas Rd. Holcom

Location: (GPS) NAD83 38 $15.028 \mathrm{~N} \mathrm{80} 32.322 \mathrm{~W}$ EPE 46ft

Natural Vegetation: sugar maple, beech, red oak

Soil Temp. Regime: mesic

Parent Material: Pottsville sandstone, residuum

Physiography: Allegheny Plateau (bench)

Slope: $3 \%$

Aspect: W

Surface Stoniness: $<0.01 \%$

A -- 0 to $5 \mathrm{~cm}$ (0 to 2 in); very dark grayish brown (10YR 3/2) loam; moderate medium granular structure; very friable.

BA -- 5 to $20 \mathrm{~cm}$ (2 to 8 in); dark yellowish brown (10YR 4/3) loam; moderate medium subangular blocky structure; friable.

Bt -- 20 to $33+\mathrm{cm}$ (8 to $13+$ in); yellowish brown (10YR 5/4) clay loam; moderate medium subangular blocky structure; friable.

Notes: This site is located off of Pocahontas Road above Holcom. The understory consists of greenbrier, oak seedlings, maple seedlings, hay-scented fern, mountain laurel, and rhododendron.

Site Number: 54

Soil Description Number: FS04WV067031

Sample Date: August 1, 2004

Area: County Rt 74 above Richwood

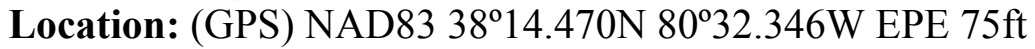

Natural Vegetation: sugar maple, beech, red oak, white oak

Soil Temp. Regime: mesic

Parent Material: Pottsville sandstone, residuum

Physiography: Allegheny Plateau (bench)

Slope: 3\%

Aspect: N 
Surface Stoniness: $<0.01 \%$

A -- 0 to $5 \mathrm{~cm}$ (0 to 2 in); dark brown (10YR 3/3) loam; moderate medium granular structure; very friable.

BA -- 5 to $15 \mathrm{~cm}$ (2 to 6 in); dark yellowish brown (10YR 5/4) loam; moderate medium subangular blocky parting to moderate medium granular structure; friable.

Bw -- 15 to $25.5+\mathrm{cm}$ (6 to $10+$ in); brownish yellow (10YR 6/6) loam; moderate medium subangular blocky structure; friable.

Notes: This site is located above Richwood on County Rt.74. The understory consists of greenbrier, oak seedlings, maple seedlings, hay-scented fern, witch hazel, and rhododendron.

Site Number: 55

Soil Description Number: FS04WV067032

Sample Date: August 1, 2004

Area: Holcom Rd

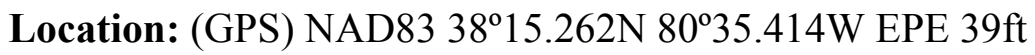

Natural Vegetation: sugar maple, beech, red oak, white oak, hemlock

Soil Temp. Regime: mesic

Parent Material: Pottsville sandstone, colluvium

Physiography: Allegheny Plateau (toeslope)

Slope: $8 \%$

Aspect: SSW

Surface Stoniness: $<0.01 \%$

A -- 0 to $7.5 \mathrm{~cm}$ ( 0 to 3 in); dark brown (10YR 3/3) loam; moderate medium granular structure; very friable.

Bt -- 7.5 to $20+$ cm (3 to $8+$ in); dark yellowish brown (10YR 4/6) loam; moderate medium subangular blocky structure; friable.

Notes: This site is located off of Holcom Road above intersection with FS rd 908. The understory consists of greenbrier, oak seedlings, striped maple, and poison ivy.

Site Number: 56

Soil Description Number: FS04WV025023

Sample Date: August 2, 2004

Area: Summit Lake - FS rd 943

Location: (GPS) NAD83 38 $14.803 \mathrm{~N} 80^{\circ} 25.242 \mathrm{~W}$ EPE 82ft

Natural Vegetation: sugar maple, beech, black cherry

Soil Temp. Regime: frigid

Parent Material: Pottsville sandstone, colluvium

Physiography: Allegheny Plateau (shoulder)

Slope: $8 \%$

Aspect: SW

Surface Stoniness: $<0.01 \%$ 
A -- 0 to $5 \mathrm{~cm}$ (0 to 2 in); dark brown (10YR 3/3) loam; moderate medium granular structure; very friable.

BA -- 5 to $15 \mathrm{~cm}$ (2 to 6 in); dark yellowish brown (10YR 4/4) loam; moderate medium subangular blocky structure; friable.

Bt -- 15 to $30.5+$ cm (6 to $12+$ in); dark yellowish brown (10YR 4/6) clay loam;

moderate medium subangular blocky structure; friable.

Notes: This site is located off of Forest Service Road 943. The understory consists of striped maple and hay-scented fern.

Site Number: 57

Soil Description Number: FS04WV025024

Sample Date: August 2, 2004

Area: Summit Lake - FS rd 943

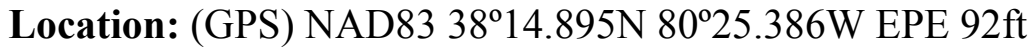

Natural Vegetation: sugar maple, beech, black cherry

Soil Temp. Regime: frigid

Parent Material: Pottsville sandstone, colluvium

Physiography: Allegheny Plateau (midslope)

Slope: $22 \%$

Aspect: SW

Surface Stoniness: $<0.01 \%$

A -- 0 to $2.5 \mathrm{~cm}$ (0 to $1 \mathrm{in})$; very dark grayish brown (10YR 3/2) silt loam; moderate medium granular structure; very friable.

BA -- 2.5 to $15 \mathrm{~cm}$ (1 to 6 in); dark yellowish brown (10YR 4/6) loam; moderate medium subangular blocky parting to moderate medium subangular blocky structure; friable.

Bw -- 15 to $25.5+$ cm (6 to $10+$ in); yellowish brown (10YR 5/8) clay loam; moderate medium subangular blocky structure; friable.

Notes: This site is located off of Forest Service Road 943. The understory consists of striped maple, beech seedlings, and hay-scented fern.

Site Number: 58

Soil Description Number: FS04WV025025

Sample Date: August 2, 2004

Area: Summit Lake - FS rd 943

Location: (GPS) NAD83 38¹5.151N 80²5.544W EPE 33ft

Natural Vegetation: sugar maple, beech, black cherry, cucumber magnolia

Soil Temp. Regime: frigid

Parent Material: Pottsville sandstone, residuum

Physiography: Allegheny Plateau (bench)

Slope: $7 \%$

Aspect: SW

Surface Stoniness: $<0.01 \%$ 
A -- 0 to $7.5 \mathrm{~cm}$ (0 to 3 in); very dark brown (10YR 2/2) loam; moderate medium granular structure; very friable.

BA -- 7.5 to $15 \mathrm{~cm}$ (3 to 6 in); dark yellowish brown (10YR 4/3) loam; moderate medium granular and moderate medium subangular blocky structure; friable.

Bt -- 15 to $28+\mathrm{cm}$ (6 to $11+$ in); yellowish brown (10YR 5/6) loam; moderate medium subangular blocky structure; friable.

Notes: This site is located off of Forest Service Road 943. The understory consists of striped maple, witch hazel, ground pine, and hay-scented fern. The water table is found at 12 in.

Site Number: 59

Soil Description Number: FS04WV067033

Sample Date: August 2, 2004

Area: Morris Creek - FS rd 99A

Location: (GPS) NAD83 38 $16.232 \mathrm{~N} 80^{\circ} 27.857 \mathrm{~W}$ EPE $33 \mathrm{ft}$

Natural Vegetation: hickory, red oak

Soil Temp. Regime: mesic

Parent Material: Pottsville sandstone, colluvium/alluvium

Physiography: Allegheny Plateau (floodplain)

Slope: $5 \%$

Aspect: S

Surface Stoniness: $<0.01 \%$

A1 -- 0 to $10 \mathrm{~cm}$ (0 to 4 in); very dark brown (10YR 2/2) loam; moderate medium granular structure; very friable.

A2 -- 10 to $15 \mathrm{~cm}$ (4 to 6 in); dark brown (10YR 3/3) loam; moderate medium granular structure; very friable.

BA -- 15 to $23+$ cm (6 to 9+ in); dark yellowish brown (10YR 4/4) loam; moderate medium subangular blocky structure; friable.

Notes: This site is located off of Forest Service Road 99A. The understory consists of striped maple, hay-scented fern, greenbrier, witch hazel, and maple, beech, and oak seedlings.

Site Number: 60

Soil Description Number: FS04WV067034

Sample Date: August 2, 2004

Area: Summit Lake - FS rd 99A

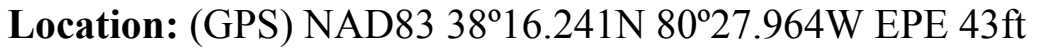

Natural Vegetation: yellow poplar, red oak, red maple, beech

Soil Temp. Regime: frigid

Parent Material: Pottsville sandstone, colluvium

Physiography: Allegheny Plateau (midslope)

Slope: $18 \%$ 
Aspect: SE

Surface Stoniness: $<0.01 \%$

A -- 0 to $7.5 \mathrm{~cm}$ (0 to 3 in); very dark grayish brown (10YR 3/2) loam; moderate medium granular structure; very friable.

BA -- 7.5 to $20 \mathrm{~cm}$ (3 to 8 in); dark yellowish brown (10YR 4/3) loam; moderate medium granular and moderate medium subangular blocky structure; friable.

Bt -- 20 to 33+ cm (8 to 13+ in); yellowish brown (10YR 5/6) loam; moderate medium subangular blocky structure; friable.

Notes: This site is located off of Forest Service Road 99A. The understory consists of striped maple, greenbrier, and beech, maple, and oak seedlings.

Site Number: 61

Soil Description Number: FS04WV101003

Sample Date: August 2, 2004

Area: Summit Lake - FS rd 99

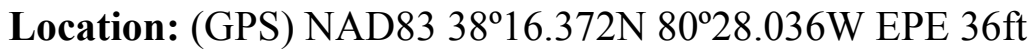

Natural Vegetation: sugar maple, red maple, red oak, yellow poplar

Soil Temp. Regime: frigid

Parent Material: Pottsville sandstone, colluvium

Physiography: Allegheny Plateau (midslope)

Slope: $17 \%$

Aspect: S

Surface Stoniness: $<0.01 \%$

A -- 0 to $5 \mathrm{~cm}$ (0 to 2 in); dark brown (10YR 3/3) loam; moderate medium granular structure; very friable.

BA -- 5 to $15 \mathrm{~cm}$ (2 to 6 in); dark yellowish brown (10YR 4/4) loam; moderate medium subangular blocky structure; friable.

Bt -- 15 to $25.5+\mathrm{cm}$ (6 to $10+$ in); yellowish brown (10YR 5/6) clay loam; moderate medium subangular blocky structure; friable.

Notes: This site is located off of Forest Service Road 943. The understory consists of striped maple and hay-scented fern.

Site Number: 62

Soil Description Number: FS04WV101004

Sample Date: August 2, 2004

Area: Summit Lake - FS rd 99

Location: (GPS) NAD83 38 $16.548 \mathrm{~N} \mathrm{80} 27.685 \mathrm{~W}$ EPE $43 \mathrm{ft}$

Natural Vegetation: sugar maple, red maple, black cherry, hickory, red oak

Soil Temp. Regime: frigid

Parent Material: Pottsville sandstone, residuum

Physiography: Allegheny Plateau (ridge)

Slope: $2 \%$ 
Aspect: SE

Surface Stoniness: $<0.01 \%$

A -- 0 to $7.5 \mathrm{~cm}$ (0 to 3 in); very dark brown (10YR 2/2) silt loam; moderate medium granular structure; very friable.

BA -- 7.5 to $18 \mathrm{~cm}$ (3 to 7 in); dark yellowish brown (10YR 4/3) silt loam; moderate medium subangular blocky parting to moderate medium granular structure; friable.

Bt -- 18 to $30.5+\mathrm{cm}$ (7 to $12+$ in); yellowish brown (10YR 5/6) loam; moderate medium subangular blocky structure; friable.

Notes: This site is located off of Forest Service Road 99. The understory consists of hayscented fern, forest grasses, and red maple seedlings.

Site Number: 63

Soil Description Number: FS04WV101005

Sample Date: August 2, 2004

Area: Summit Lake - FS rd 99

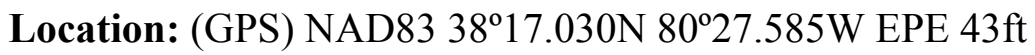

Natural Vegetation: sugar maple, beech, black cherry

Soil Temp. Regime: frigid

Parent Material: Pottsville sandstone, colluvium

Physiography: Allegheny Plateau (bench)

Slope: $4 \%$

Aspect: SE

Surface Stoniness: $<0.01 \%$

$1 \mathrm{A1}$-- 0 to $10 \mathrm{~cm}$ (0 to 4 in); very dark grayish brown (10YR 3/2) sandy loam; moderate medium granular structure; very friable.

$1 \mathrm{A2}$-- 10 to $30.5 \mathrm{~cm}$ (4 to $12 \mathrm{in);} \mathrm{dark} \mathrm{brown} \mathrm{(10YR} \mathrm{3/3)} \mathrm{sandy} \mathrm{loam;} \mathrm{moderate} \mathrm{medium}$ granular blocky structure; friable.

$\mathbf{2 A b}$-- 30.5 to $43+\mathrm{cm}$ (12 to $17+$ in); very dark brown (10YR 2/2) silt loam; moderate medium granular structure; friable.

Notes: This site is located off of Forest Service Road 99. The understory consists of striped maple, hay-scented fern, violets, witch hazel, and maple and beech seedlings.

Site Number: 64

Soil Description Number: FS04WV101006

Sample Date: August 2, 2004

Area: Summit Lake - FS rd 99

Location: (GPS) NAD83 38²16.388N 80²6.418W EPE 62ft

Natural Vegetation: sugar maple, beech, black cherry, red oak

Soil Temp. Regime: frigid

Parent Material: Pottsville sandstone, residuum

Physiography: Allegheny Plateau (bench)

Slope: $5 \%$ 
Aspect: W

Surface Stoniness: $<0.01 \%$

A -- 0 to $5 \mathrm{~cm}$ (0 to 2 in); dark brown (10YR 3/3) loam; moderate medium granular structure; very friable.

BA -- 5 to $20 \mathrm{~cm}$ (2 to 8 in); dark yellowish brown (10YR 4/4) loam; moderate medium subangular blocky parting to moderate medium granular structure; friable.

Bt -- 20 to $33+\mathrm{cm}(8$ to $13+$ in); yellowish brown $(10 \mathrm{YR} 5 / 6)$ clay loam; moderate medium subangular blocky structure; friable.

Notes: This site is located off of Forest Service Road 99. The understory consists of striped maple, hay-scented fern, violets, and forest grasses.

Site Number: 65

Soil Description Number: FS04WV025026

Sample Date: August 4, 2004

Area: Summit Lake - lake path

Location: (GPS) NAD83 38²15.419N 80²6.326W EPE 105ft

Natural Vegetation: Beech, red oak, red maple, black cherry

Soil Temp. Regime: frigid

Parent Material: Pottsville sandstone, colluvium

Physiography: Allegheny Plateau (toeslope)

Slope: $2 \%$

Aspect: E

Surface Stoniness: $<0.01 \%$

A -- 0 to $10 \mathrm{~cm}$ (0 to 4 in); dark brown (10YR 3/3) loam; moderate medium granular structure; very friable.

BA -- 10 to $23 \mathrm{~cm}$ (4 to 9 in); dark yellowish brown (10YR 5/4) loam; moderate medium subangular blocky parting to moderate medium granular structure; friable.

Bt -- 23 to $35.5+\mathrm{cm}$ (9 to $14+$ in); yellowish brown (10YR 5/6) clay loam; moderate medium subangular blocky structure; friable.

Notes: This site is located west of Summit Lake along the path bordering the lake. The understory consists of hay-scented fern, striped maple, cucumber root, and beech, maple, and cherry seedlings. There are white 10YR 7/1 mottles in the BA horizon only.

Site Number: 66

Soil Description Number: FS04WV025027

Sample Date: August 4, 2004

Area: Summit Lake - lake path

Location: (GPS) NAD83 38¹5.1N42 80²6.313W EPE 105ft

Natural Vegetation: Beech, red oak, red maple, black cherry

Soil Temp. Regime: frigid

Parent Material: Pottsville sandstone, colluvium

Physiography: Allegheny Plateau (toeslope) 
Slope: $6 \%$

Aspect: E

Surface Stoniness: $<0.01 \%$

A -- 0 to $5 \mathrm{~cm}$ (0 to 2 in); dark brown (10YR 3/3) mucky loam; moderate medium granular structure; very friable.

BA -- 5 to $10 \mathrm{~cm}$ (2 to 4 in); dark yellowish brown (10YR 4/4) loam; moderate medium subangular blocky parting to moderate medium granular structure; friable.

Bt -- 10 to $20+\mathrm{cm}$ (4 to $8+$ in); yellowish brown (10YR 5/8) clay loam; moderate medium subangular blocky structure; friable.

Notes: This site is located west of Summit Lake along the path that borders the lake. The understory consists of hay-scented fern, striped maple, forest grasses, and beech, maple, and oak seedlings.

Site Number: 67

Soil Description Number: FS04WV025022

Sample Date: July 28, 2004

Area: Summit Lake - FS rd 786

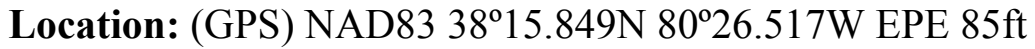

Natural Vegetation: sugar maple, beech, black cherry

Soil Temp. Regime: frigid

Parent Material: Pottsville sandstone, residuum

Physiography: Allegheny Plateau (ridge)

Slope: $<1 \%$

Aspect: NW

Surface Stoniness: $<0.01 \%$

A -- 0 to $10 \mathrm{~cm}$ (0 to 4 in); very dark grayish brown (10YR 3/2) loam; moderate medium granular structure; very friable.

Bt -- 10 to $23+$ cm (4 to 9+ in); dark yellowish brown (10YR 4/6) clay loam; moderate medium subangular blocky structure; friable.

Notes: This site is located off of Forest Service Road 786. The understory consists of forest grasses, striped maple, and sugar maple seedlings. 


\section{APPENDIX D \\ PHYSICAL PROPERTIES DATA}

\begin{tabular}{|c|c|c|c|c|c|c|c|c|c|}
\hline \multirow[b]{2}{*}{$\begin{array}{l}\text { Descrip. } \\
\text { Page \# }\end{array}$} & \multirow[b]{2}{*}{ Sample ID } & \multirow[b]{2}{*}{$\begin{array}{l}\text { Wshed } \\
\text { Area }\end{array}$} & \multirow[b]{2}{*}{$\begin{array}{l}\text { Landscape } \\
\text { Position }\end{array}$} & \multirow[b]{2}{*}{$\begin{array}{c}\text { Sand } \\
\%\end{array}$} & \multirow[b]{2}{*}{$\begin{array}{l}\text { Silt } \\
\%\end{array}$} & \multirow[b]{2}{*}{$\begin{array}{c}\text { Clay } \\
\%\end{array}$} & \multirow[b]{2}{*}{ Texture } & \multicolumn{2}{|c|}{$\begin{array}{l}\text { Bulk Density } \\
\mathrm{g} \mathrm{cm}^{-3}\end{array}$} \\
\hline & & & & & & & & Clod & Frame \\
\hline \multirow[t]{8}{*}{69} & FS04WV025001A1 & East & Back slope & 38 & 38 & 24 & Loam & & 0.26 \\
\hline & FS04WV025001A2 & East & Back slope & 37 & 37 & 25 & Loam & & 0.63 \\
\hline & FS04WV025001AB & East & Back slope & 35 & 34 & 31 & Clay Loam & & 1.13 \\
\hline & FS04WV025001Bw1 & East & Back slope & 43 & 33 & 24 & Loam & 1.36 & \\
\hline & FS04WV025001Bw2 & East & Back slope & 43 & 33 & 24 & Loam & 1.26 & \\
\hline & FS04WV025001Bw3 & East & Back slope & 51 & 29 & 20 & Loam & 1.00 & \\
\hline & FS04WV025001Bw4 & East & Back slope & 62 & 24 & 14 & Sandy Loam & 1.19 & \\
\hline & FS04WV025001BC & East & Back slope & 67 & 25 & 8 & Sandy Loam & 1.11 & \\
\hline \multirow[t]{7}{*}{71} & FS04WV025002A & East & Back slope & 21 & 50 & 30 & Clay Loam & & 0.68 \\
\hline & FS04WV025002AB & East & Back slope & 23 & 51 & 26 & Silt Loam & 1.01 & 0.72 \\
\hline & FS04WV025002Bw1 & East & Back slope & 26 & 44 & 30 & Clay Loam & 1.01 & \\
\hline & FS04WV025002Bw2 & East & Back slope & 25 & 46 & 29 & Clay Loam & 1.03 & \\
\hline & FS04WV025002Bw3 & East & Back slope & 31 & 44 & 26 & Loam & 1.30 & \\
\hline & FS04WV025002BC1 & East & Back slope & 31 & 49 & 20 & Loam & 1.20 & \\
\hline & FS04WV025002BC2 & East & Back slope & 27 & 51 & 22 & Silt Loam & 1.26 & \\
\hline \multirow[t]{5}{*}{73} & FS04WV025003A & East & Ridge & 8 & 58 & 33 & $\begin{array}{l}\text { Silty Clay } \\
\text { Loam }\end{array}$ & & 1.15 \\
\hline & FS04WV025003Bw1 & East & Ridge & 10 & 60 & 30 & $\begin{array}{l}\text { Silty Clay } \\
\text { Loam }\end{array}$ & 1.17 & \\
\hline & FS04WV025003Bw2 & East & Ridge & 14 & 57 & 29 & $\begin{array}{l}\text { Silty Clay } \\
\text { Loam }\end{array}$ & 1.37 & \\
\hline & FS04WV025003Bx1 & East & Ridge & 13 & 69 & 18 & Silt Loam & 1.50 & \\
\hline & FS04WV025003Bx2 & East & Ridge & 11 & 65 & 23 & Silt Loam & 1.77 & \\
\hline \multirow[t]{8}{*}{75} & FS04WV025004A & East & Foot & 37 & 42 & 21 & Loam & & 1.23 \\
\hline & FS04WV025004AB & East & Foot & 32 & 52 & 16 & Silt Loam & 1.09 & \\
\hline & FS04WV025004Bw1 & East & Foot & 27 & 49 & 24 & Loam & 1.02 & \\
\hline & FS04WV025004Bw2 & East & Foot & 26 & 56 & 18 & Silt Loam & 1.40 & \\
\hline & FS04WV025004Bw3 & East & Foot & 34 & 50 & 17 & Loam & 1.47 & \\
\hline & FS04WV025004BW4 & East & Foot & 42 & 40 & 18 & Loam & 1.63 & \\
\hline & FS04WV025004Bx & East & Foot & 33 & 49 & 18 & Loam & 1.60 & \\
\hline & FS04WV025004BC & East & Foot & 44 & 43 & 13 & Loam & 1.62 & \\
\hline \multirow[t]{3}{*}{77} & FS04WV025005A & East & Bench & 26 & 53 & 21 & Silt Loam & & 0.36 \\
\hline & FS04WV025005AB & East & Bench & 25 & 39 & 36 & Silt Loam & 0.78 & \\
\hline & FS04WV025005Bw1 & East & Bench & 20 & 47 & 33 & $\begin{array}{l}\text { Silty Clay } \\
\text { Loam }\end{array}$ & 1.03 & \\
\hline
\end{tabular}




\begin{tabular}{|c|c|c|c|c|c|c|c|c|c|}
\hline \multirow[b]{2}{*}{$\begin{array}{l}\text { Descrip. } \\
\text { Page \# }\end{array}$} & \multirow[b]{2}{*}{ Sample ID } & \multirow[b]{2}{*}{$\begin{array}{l}\text { Wshed } \\
\text { Area }\end{array}$} & \multirow[b]{2}{*}{$\begin{array}{l}\text { Landscape } \\
\text { Position }\end{array}$} & \multirow[b]{2}{*}{$\begin{array}{c}\text { Sand } \\
\%\end{array}$} & \multirow[b]{2}{*}{$\begin{array}{l}\text { Silt } \\
\%\end{array}$} & \multirow[b]{2}{*}{$\begin{array}{c}\text { Clay } \\
\%\end{array}$} & \multirow[b]{2}{*}{ Texture } & \multicolumn{2}{|c|}{$\begin{array}{l}\text { Bulk Density } \\
\mathrm{g} \mathrm{cm}^{-3}\end{array}$} \\
\hline & & & & & & & & Clod & Frame \\
\hline & FS04WV025005Bw2 & East & Bench & 23 & 51 & 26 & Loam & 1.50 & \\
\hline & FS04WV025005Bx1 & East & Bench & 28 & 51 & 22 & Loam & 1.48 & \\
\hline & FS04WV025005Bx2 & East & Bench & 34 & 45 & 22 & Loam & 1.62 & \\
\hline & FS04WV025005B 33 & East & Bench & 21 & 47 & 31 & Clay Loam & 1.72 & \\
\hline & FS04WV025005BC & East & Bench & 15 & 45 & 40 & Clay & 1.65 & \\
\hline \multirow[t]{6}{*}{79} & FS04WV025010A/E & East & Shoulder & 13 & 69 & 18 & Silt Loam & & 0.91 \\
\hline & FS04WV025010BA & East & Shoulder & & & & & 1.32 & \\
\hline & FS04WV025010Bt & East & Shoulder & 13 & 46 & 41 & $\begin{array}{l}\text { Silty Clay } \\
\text { Loam }\end{array}$ & 1.46 & \\
\hline & FS04WV025010Btx1 & East & Shoulder & 24 & 57 & 19 & Silt Loam & 1.58 & \\
\hline & FS04WV025010Btx2 & East & Shoulder & 21 & 51 & 28 & Clay Loam & 1.58 & \\
\hline & FS04WV025010BC & East & Shoulder & 13 & 55 & 32 & $\begin{array}{l}\text { Silty Clay } \\
\text { Loam }\end{array}$ & 1.58 & \\
\hline \multirow[t]{5}{*}{81} & FS04WV025019A & East & Floodplain & & & & & & \\
\hline & FS04WV025019Bw1 & East & Floodplain & 49 & 27 & 24 & Loam & & \\
\hline & FS04WV025019Bw2 & East & Floodplain & 45 & 31 & 24 & Loam & & \\
\hline & FS04WV025019Bw3 & East & Floodplain & 50 & 36 & 14 & Loam & & \\
\hline & FS04WV025019BC & East & Floodplain & 38 & 47 & 15 & Loam & & \\
\hline \multirow[t]{5}{*}{83} & FS04WV101001A & East & Ridge & 11 & 66 & 23 & Silt Loam & & 0.51 \\
\hline & FS04WV101001BA & East & Ridge & 13 & 58 & 29 & $\begin{array}{l}\text { Silty Clay } \\
\text { Loam }\end{array}$ & & 0.91 \\
\hline & FS04WV101001Bt1 & East & Ridge & 49 & 22 & 29 & $\begin{array}{l}\text { Sandy Clay } \\
\text { Loam }\end{array}$ & 1.40 & \\
\hline & FS04WV101001Bt2 & East & Ridge & 13 & 61 & 26 & Silt Loam & 0.95 & \\
\hline & FS04WV101001Bt3 & East & Ridge & 13 & 70 & 17 & Silt Loam & 1.33 & \\
\hline \multirow[t]{6}{*}{84} & FS04WV067007A & East & Shoulder & 34 & 46 & 20 & Loam & & 0.38 \\
\hline & FS04WV067007BA & East & Shoulder & 30 & 58 & 12 & Silt Loam & 1.04 & \\
\hline & FS04WV067007Bw1 & East & Shoulder & 33 & 52 & 15 & Silt Loam & 1.07 & \\
\hline & FS04WV067007Bw2 & East & Shoulder & 29 & 55 & 16 & Silt Loam & 1.12 & \\
\hline & FS04WV067007Bw3 & East & Shoulder & 32 & 60 & 8 & Silt Loam & 1.21 & \\
\hline & FS04WV067007BC & East & Shoulder & 35 & 54 & 11 & Silt Loam & 1.37 & \\
\hline \multirow[t]{7}{*}{85} & FS04WV067001A & West & Back slope & 39 & 49 & 12 & Loam & & 0.49 \\
\hline & FS04WV067001AB & West & Back slope & 43 & 44 & 13 & Loam & 1.48 & \\
\hline & FS04WV067001BA & West & Back slope & 44 & 43 & 13 & Loam & 1.56 & \\
\hline & FS04WV067001Bw1 & West & Back slope & 45 & 41 & 14 & Loam & 1.55 & \\
\hline & FS04WV067001Bw2 & West & Back slope & 61 & 23 & 16 & Sandy Loam & 1.27 & \\
\hline & FS04WV067001BC & West & Back slope & 61 & 27 & 12 & Sandy Loam & 1.58 & \\
\hline & FS04WV067001C & West & Back slope & 65 & 27 & 8 & Sandy Loam & 1.82 & \\
\hline
\end{tabular}




\begin{tabular}{|c|c|c|c|c|c|c|c|c|c|}
\hline \multirow[b]{2}{*}{$\begin{array}{l}\text { Descrip. } \\
\text { Page \# }\end{array}$} & \multirow[b]{2}{*}{ Sample ID } & \multirow[b]{2}{*}{$\begin{array}{l}\text { Wshed } \\
\text { Area }\end{array}$} & \multirow[b]{2}{*}{$\begin{array}{l}\text { Landscape } \\
\text { Position }\end{array}$} & \multirow[b]{2}{*}{$\begin{array}{c}\text { Sand } \\
\%\end{array}$} & \multirow[b]{2}{*}{$\begin{array}{l}\text { Silt } \\
\%\end{array}$} & \multirow[b]{2}{*}{$\begin{array}{c}\text { Clay } \\
\%\end{array}$} & \multirow[b]{2}{*}{ Texture } & \multicolumn{2}{|c|}{$\begin{array}{l}\text { Bulk Density } \\
\mathrm{g} \mathrm{cm}^{-3}\end{array}$} \\
\hline & & & & & & & & Clod & Frame \\
\hline \multirow[t]{4}{*}{87} & FS04WV067002A & West & Ridge & 42 & 38 & 20 & Loam & 1.15 & 0.74 \\
\hline & FS04WV067002BA & West & Ridge & 52 & 32 & 15 & Sandy Loam & 1.30 & \\
\hline & FS04WV067002Bw1 & West & Ridge & 55 & 31 & 14 & Sandy Loam & 1.36 & \\
\hline & FS04WV067002Bw2 & West & Ridge & 62 & 28 & 10 & Sandy Loam & 1.50 & \\
\hline \multirow[t]{5}{*}{88} & FS04WV067003A & West & Ridge & 35 & 49 & 15 & Loam & 0.85 & 0.62 \\
\hline & FS04WV067003AB & West & Ridge & 38 & 43 & 19 & Loam & 1.09 & \\
\hline & FS04WV067003Bw1 & West & Ridge & 42 & 40 & 18 & Loam & 1.55 & \\
\hline & FS04WV067003Bw2 & West & Ridge & 46 & 44 & 10 & Loam & 1.68 & \\
\hline & FS04WV067003BC & West & Ridge & 43 & 38 & 18 & Loam & 1.75 & \\
\hline \multirow[t]{8}{*}{89} & FS04WV067004A & West & Floodplain & 61 & 28 & 11 & Sandy Loam & 1.11 & 0.70 \\
\hline & FS04WV067004BA & West & Floodplain & 52 & 31 & 16 & Sandy Loam & 1.28 & \\
\hline & FS04WV067004Bw1 & West & Floodplain & 48 & 32 & 19 & Loam & 1.22 & \\
\hline & FS04WV067004Bw2 & West & Floodplain & 32 & 33 & 35 & Clay Loam & 1.43 & \\
\hline & FS04WV067004Ab & West & Floodplain & 49 & 37 & 14 & Loam & & \\
\hline & FS04WV067004C1 & West & Floodplain & 65 & 30 & 6 & Sandy Loam & & \\
\hline & FS04WV067004C2 & West & Floodplain & 79 & 13 & 8 & Loamy Sand & & \\
\hline & FS04WV067004C3 & West & Floodplain & 74 & 17 & 10 & Sandy Loam & & \\
\hline \multirow[t]{8}{*}{91} & FS04WV067005A & West & Bench & 45 & 43 & 12 & Loam & & 0.56 \\
\hline & FS04WV067005AB & West & Bench & 47 & 39 & 14 & Loam & 1.22 & \\
\hline & FS04WV067005Bw1 & West & Bench & 45 & 33 & 22 & Loam & 1.39 & \\
\hline & FS04WV067005Bw2 & West & Bench & & & & & 1.44 & \\
\hline & FS04WV067005Bw3 & West & Bench & 58 & 32 & 10 & Sandy Loam & 1.50 & \\
\hline & FS04WV067005Bx1 & West & Bench & 26 & 63 & 11 & Silt Loam & 1.68 & \\
\hline & FS04WV067005Bx2 & West & Bench & 13 & 62 & 25 & Silt Loam & 1.71 & \\
\hline & FS04WV067005C & West & Bench & 33 & 52 & 16 & Silt Loam & 1.73 & \\
\hline \multirow{7}{*}{93} & & & & & & & Silty Clay & & \\
\hline & FS04WV067006A & West & Foot & 19 & 50 & 31 & Loam & & 0.58 \\
\hline & FS04WV067006AB & West & Foot & 23 & 47 & 30 & Clay Loam & 1.00 & \\
\hline & FS04WV067006Bw1 & West & Foot & 18 & 58 & 24 & Silt Loam & 1.27 & \\
\hline & FS04WV067006Bw2 & West & Foot & 19 & 52 & 30 & $\begin{array}{l}\text { Silty Clay } \\
\text { Loam }\end{array}$ & 1.42 & \\
\hline & FS04WV067006Bw3 & West & Foot & 27 & 56 & 17 & Silt Loam & 1.47 & \\
\hline & FS04WV067006BC & West & Foot & 31 & 54 & 16 & Silt Loam & 1.43 & \\
\hline \multirow[t]{4}{*}{95} & FS04WV067017A1 & West & Shoulder & 49 & 40 & 11 & Loam & & 0.56 \\
\hline & FS04WV067017A2 & West & Shoulder & 47 & 42 & 11 & Loam & & 0.77 \\
\hline & FS04WV067017BA & West & Shoulder & 44 & 40 & 16 & Loam & 1.21 & \\
\hline & FS04WV067017Bw & West & Shoulder & 43 & 37 & 20 & Loam & 1.25 & \\
\hline
\end{tabular}




\begin{tabular}{|c|c|c|c|c|c|c|c|c|c|}
\hline \multirow[b]{2}{*}{$\begin{array}{l}\text { Descrip. } \\
\text { Page \# }\end{array}$} & \multirow[b]{2}{*}{ Sample ID } & \multirow[b]{2}{*}{$\begin{array}{l}\text { Wshed } \\
\text { Area }\end{array}$} & \multirow[b]{2}{*}{$\begin{array}{l}\text { Landscape } \\
\text { Position }\end{array}$} & \multirow[b]{2}{*}{$\begin{array}{c}\text { Sand } \\
\%\end{array}$} & \multirow[b]{2}{*}{$\begin{array}{l}\text { Silt } \\
\%\end{array}$} & \multirow[b]{2}{*}{$\begin{array}{c}\text { Clay } \\
\%\end{array}$} & \multirow[b]{2}{*}{ Texture } & \multicolumn{2}{|c|}{$\begin{array}{l}\text { Bulk Density } \\
\mathrm{g} \mathrm{cm}^{-3}\end{array}$} \\
\hline & & & & & & & & Clod & Frame \\
\hline & FS04WV067017BC & West & Shoulder & 12 & 72 & 17 & Silt Loam & 1.43 & \\
\hline & FS04WV067017C & West & Shoulder & 59 & 31 & 10 & Sandy Loam & 1.63 & \\
\hline \multirow[t]{3}{*}{96} & FS04WV025006A & East & Back slope & 52 & 37 & 11 & Loam & & \\
\hline & FS04WV025006BA & East & Back slope & 46 & 41 & 13 & Loam & & \\
\hline & FS04WV025006Bt & East & Back slope & 43 & 37 & 20 & Loam & & \\
\hline \multirow[t]{3}{*}{96} & FS04WV025007A & East & Bench & 46 & 35 & 18 & Loam & & \\
\hline & FS04WV025007BA & East & Bench & 46 & 33 & 21 & Loam & & \\
\hline & FS04WV025007Bw & East & Bench & 52 & 32 & 16 & Loam & & \\
\hline \multirow[t]{2}{*}{97} & FS04WV025008A & East & Floodplain & 22 & 43 & 35 & Clay Loam & & \\
\hline & FS04WV025008Bt & East & Floodplain & 23 & 36 & 41 & Clay & & \\
\hline \multirow[t]{2}{*}{97} & FS04WV025009A & East & Foot & 22 & 55 & 23 & Silt Loam & & \\
\hline & FS04WV025009Bt & East & Foot & 13 & 51 & 37 & $\begin{array}{l}\text { Silty Clay } \\
\text { Loam }\end{array}$ & & \\
\hline \multirow[t]{3}{*}{98} & FS04WV025011A & East & Shoulder & 22 & 43 & 34 & Clay Loam & & \\
\hline & FS04WV025011BA & East & Shoulder & 23 & 49 & 28 & Clay Loam & & \\
\hline & FS04WV025011Bt & East & Shoulder & 34 & 44 & 22 & Loam & & \\
\hline \multirow[t]{2}{*}{98} & FS04WV025012A & East & Bench & 19 & 49 & 31 & Clay Loam & & \\
\hline & FS04WV025012Bw & East & Bench & 32 & 47 & 22 & Loam & & \\
\hline \multirow[t]{3}{*}{99} & FS04WV025013A & East & Ridge & 60 & 25 & 15 & Sandy Loam & & \\
\hline & FS04WV025013BA & East & Ridge & 48 & 35 & 17 & Loam & & \\
\hline & FS04WV025013Bt & East & Ridge & 18 & 46 & 36 & Clay Loam & & \\
\hline \multirow[t]{3}{*}{99} & FS04WV025014A & East & Back slope & & & & & & \\
\hline & FS04WV025014BA & East & Back slope & 14 & 55 & 31 & $\begin{array}{l}\text { Silty Clay } \\
\text { Loam }\end{array}$ & & \\
\hline & FS04WV025014Bt & East & Back slope & 12 & 51 & 37 & $\begin{array}{l}\text { Silty Clay } \\
\text { Loam }\end{array}$ & & \\
\hline \multirow[t]{2}{*}{100} & FS04WV025015A & East & Shoulder & 22 & 49 & 28 & Clay Loam & & \\
\hline & FS04WV025015Bt & East & Shoulder & 15 & 52 & 33 & $\begin{array}{l}\text { Silty Clay } \\
\text { Loam }\end{array}$ & & \\
\hline \multirow[t]{3}{*}{100} & FS04WV067008A & West & Foot & 23 & 57 & 20 & Silt Loam & & \\
\hline & FS04WV067008BA & West & Foot & 17 & 59 & 24 & Silt Loam & & \\
\hline & FS04WV067008Bw & West & Foot & 20 & 56 & 24 & Silt Loam & & \\
\hline
\end{tabular}




\begin{tabular}{|c|c|c|c|c|c|c|c|c|c|}
\hline \multirow[b]{2}{*}{$\begin{array}{l}\text { Descrip. } \\
\text { Page \# }\end{array}$} & \multirow[b]{2}{*}{ Sample ID } & \multirow[b]{2}{*}{$\begin{array}{l}\text { Wshed } \\
\text { Area }\end{array}$} & \multirow[b]{2}{*}{$\begin{array}{l}\text { Landscape } \\
\text { Position }\end{array}$} & \multirow[b]{2}{*}{$\begin{array}{c}\text { Sand } \\
\%\end{array}$} & \multirow[b]{2}{*}{$\begin{array}{l}\text { Silt } \\
\%\end{array}$} & \multirow[b]{2}{*}{$\begin{array}{c}\text { Clay } \\
\%\end{array}$} & \multirow[b]{2}{*}{ Texture } & \multicolumn{2}{|c|}{$\begin{array}{c}\text { Bulk Density } \\
\mathrm{g} \mathrm{cm}^{-3}\end{array}$} \\
\hline & & & & & & & & Clod & Frame \\
\hline \multirow[t]{3}{*}{101} & FS04WV067009A & West & Floodplain & 54 & 38 & 8 & Sandy Loam & & \\
\hline & FS04WV067009BA & West & Floodplain & 74 & 19 & 7 & Sandy Loam & & \\
\hline & FS04WV067009Bg & West & Floodplain & 65 & 30 & 5 & Sandy Loam & & \\
\hline \multirow[t]{3}{*}{101} & FS04WV067010A & West & Back slope & 31 & 46 & 23 & Loam & & \\
\hline & FS04WV067010BA & West & Back slope & 28 & 47 & 25 & Loam & & \\
\hline & FS04WV067010Bw & West & Back slope & 32 & 50 & 18 & Silt Loam & & \\
\hline \multirow[t]{2}{*}{102} & FS04WV067011BA & West & Floodplain & 54 & 37 & 9 & Sandy Loam & & \\
\hline & FS04WV067011Bw & West & Floodplain & 71 & 24 & 5 & Sandy Loam & & \\
\hline \multirow[t]{3}{*}{102} & FS04WV067012A & West & Ridge & 8 & 71 & 21 & Silt Loam & & \\
\hline & FS04WV067012BA & West & Ridge & & & & & & \\
\hline & FS04WV067012Bw & West & Ridge & 9 & 64 & 27 & Silt Loam & & \\
\hline \multirow[t]{3}{*}{103} & FS04WV067013A & West & Back slope & 54 & 34 & 11 & Sandy Loam & & \\
\hline & FS04WV067013BA & West & Back slope & 51 & 37 & 12 & Loam & & \\
\hline & FS04WV067013Bw & West & Back slope & 51 & 39 & 11 & Loam & & \\
\hline \multirow[t]{3}{*}{103} & FS04WV067014A & West & Bench & 19 & 66 & 15 & Silt Loam & & \\
\hline & FS04WV067014BA & West & Bench & 20 & 55 & 25 & Silt Loam & & \\
\hline & FS04WV067014Bw & West & Bench & 23 & 53 & 25 & Silt Loam & & \\
\hline \multirow[t]{3}{*}{104} & FS04WV067015A & West & Shoulder & 35 & 38 & 27 & Loam & & \\
\hline & FS04WV067015BA & West & Shoulder & 39 & 36 & 25 & Loam & & \\
\hline & FS04WV067015Bw & West & Shoulder & 33 & 51 & 16 & Silt Loam & & \\
\hline \multirow[t]{3}{*}{104} & FS04WV067016A & West & Ridge & 52 & 39 & 10 & Loam & & \\
\hline & FS04WV067016BA & West & Ridge & 48 & 39 & 13 & Loam & & \\
\hline & FS04WV067016Bt & West & Ridge & 49 & 36 & 15 & Loam & & \\
\hline \multirow[t]{3}{*}{105} & FS04WV025016A1 & East & Floodplain & 41 & 19 & 40 & Clay & & \\
\hline & FS04WV025016A2 & East & Floodplain & 32 & 43 & 26 & Loam & & \\
\hline & FS04WV025016Bw & East & Floodplain & 42 & 40 & 18 & Loam & & \\
\hline \multirow[t]{3}{*}{105} & FS04WV025017A & East & Back slope & 37 & 32 & 31 & Clay Loam & & \\
\hline & FS04WV025017BA & East & Back slope & 16 & 48 & 35 & $\begin{array}{l}\text { Silty Clay } \\
\text { Loam }\end{array}$ & & \\
\hline & FS04WV025017Bt & East & Back slope & 11 & 48 & 41 & Silty Clay & & \\
\hline \multirow[t]{2}{*}{106} & FS04WV025018A & East & Foot & 27 & 46 & 27 & Clay Loam & & \\
\hline & FS04WV025018Bw & East & Foot & 29 & 47 & 24 & Loam & & \\
\hline
\end{tabular}




\begin{tabular}{|c|c|c|c|c|c|c|c|c|c|}
\hline \multirow[b]{2}{*}{$\begin{array}{l}\text { Descrip. } \\
\text { Page \# }\end{array}$} & \multirow[b]{2}{*}{ Sample ID } & \multirow[b]{2}{*}{$\begin{array}{l}\text { Wshed } \\
\text { Area }\end{array}$} & \multirow[b]{2}{*}{$\begin{array}{l}\text { Landscape } \\
\text { Position }\end{array}$} & \multirow[b]{2}{*}{$\begin{array}{c}\text { Sand } \\
\%\end{array}$} & \multirow[b]{2}{*}{$\begin{array}{l}\text { Silt } \\
\%\end{array}$} & \multirow[b]{2}{*}{$\begin{array}{c}\text { Clay } \\
\%\end{array}$} & \multirow[b]{2}{*}{ Texture } & \multicolumn{2}{|c|}{$\begin{array}{l}\text { Bulk Density } \\
\mathrm{g} \mathrm{cm}^{-3}\end{array}$} \\
\hline & & & & & & & & Clod & Frame \\
\hline \multirow[t]{3}{*}{106} & FS04WV067018A & West & Foot & 53 & 32 & 15 & Sandy Loam & & \\
\hline & FS04WV067018BA & West & Foot & 54 & 35 & 11 & Sandy Loam & & \\
\hline & FS04WV067018Bt & West & Foot & 54 & 35 & 12 & Sandy Loam & & \\
\hline \multirow[t]{3}{*}{107} & FS04WV067019A & West & Bench & 37 & 48 & 15 & Loam & & \\
\hline & FS04WV067019BA & West & Bench & 37 & 40 & 23 & Loam & & \\
\hline & FS04WV067019Bw & West & Bench & 37 & 56 & 7 & Silt Loam & & \\
\hline \multirow[t]{3}{*}{107} & FS04WV067020A & West & Shoulder & 58 & 35 & 6 & Sandy Loam & & \\
\hline & FS04WV067020BA & West & Shoulder & 60 & 30 & 10 & Sandy Loam & & \\
\hline & FS04WV067020Bt & West & Shoulder & 56 & 31 & 13 & Sandy Loam & & \\
\hline \multirow[t]{3}{*}{108} & FS04WV067021A & West & Ridge & 46 & 39 & 15 & Loam & & \\
\hline & FS04WV067021BA & West & Ridge & 44 & 42 & 14 & Loam & & \\
\hline & FS04WV067021Bw & West & Ridge & 42 & 45 & 13 & Loam & & \\
\hline \multirow[t]{3}{*}{108} & FS04WV067022A1 & West & Shoulder & 82 & 12 & 6 & Loamy Sand & & \\
\hline & FS04WV067022A2 & West & Shoulder & 84 & 13 & 3 & Loamy Sand & & \\
\hline & FS04WV067022AB & West & Shoulder & 82 & 16 & 2 & Loamy Sand & & \\
\hline \multirow[t]{3}{*}{109} & FS04WV067023A & West & Ridge & 27 & 51 & 22 & Silt Loam & & \\
\hline & FS04WV067023BA & West & Ridge & 32 & 38 & 30 & Clay Loam & & \\
\hline & FS04WV067023Bw & West & Ridge & 27 & 46 & 26 & Loam & & \\
\hline \multirow[t]{2}{*}{109} & FS04WV067024BA & West & Back slope & 18 & 57 & 25 & Silt Loam & & \\
\hline & FS04WV067024Bt & West & Back slope & 19 & 54 & 28 & $\begin{array}{l}\text { Silty Clay } \\
\text { Loam }\end{array}$ & & \\
\hline \multirow[t]{3}{*}{110} & FS04WV025020A & East & Bench & 43 & 40 & 16 & Loam & & \\
\hline & FS04WV025020BA & East & Bench & 62 & 20 & 18 & Sandy Loam & & \\
\hline & FS04WV025020Bt & East & Bench & 32 & 38 & 30 & Clay Loam & & \\
\hline \multirow[t]{3}{*}{110} & FS04WV025021A & East & Back slope & 19 & 50 & 31 & $\begin{array}{l}\text { Silty Clay } \\
\text { Loam }\end{array}$ & & \\
\hline & FS04WV025021BA & East & Back slope & 15 & 44 & 41 & Silty Clay & & \\
\hline & FS04WV025021Bw & East & Back slope & 16 & 53 & 31 & $\begin{array}{l}\text { Silty Clay } \\
\text { Loam }\end{array}$ & & \\
\hline \multirow[t]{3}{*}{111} & FS04WV101002A & East & Ridge & 7 & 71 & 23 & Silt Loam & & \\
\hline & FS04WV101002BA & East & Ridge & 23 & 44 & 33 & Clay Loam & & \\
\hline & FS04WV101002Bt & East & Ridge & 12 & 51 & 37 & $\begin{array}{l}\text { Silty Clay } \\
\text { Loam }\end{array}$ & & \\
\hline
\end{tabular}




\begin{tabular}{|c|c|c|c|c|c|c|c|c|c|}
\hline \multirow[b]{2}{*}{$\begin{array}{l}\text { Descrip. } \\
\text { Page \# }\end{array}$} & \multirow[b]{2}{*}{ Sample ID } & \multirow[b]{2}{*}{$\begin{array}{l}\text { Wshed } \\
\text { Area }\end{array}$} & \multirow[b]{2}{*}{$\begin{array}{l}\text { Landscape } \\
\text { Position }\end{array}$} & \multirow[b]{2}{*}{$\begin{array}{c}\text { Sand } \\
\%\end{array}$} & \multirow[b]{2}{*}{$\begin{array}{l}\text { Silt } \\
\%\end{array}$} & \multirow[b]{2}{*}{$\begin{array}{c}\text { Clay } \\
\%\end{array}$} & \multirow[b]{2}{*}{ Texture } & \multicolumn{2}{|c|}{$\begin{array}{l}\text { Bulk Density } \\
\mathrm{g} \mathrm{cm}^{-3}\end{array}$} \\
\hline & & & & & & & & Clod & Frame \\
\hline \multirow[t]{3}{*}{111} & FS04WV067025A & West & Ridge & 65 & 22 & 12 & Sandy Loam & & \\
\hline & FS04WV067025BA & West & Ridge & 50 & 36 & 14 & Loam & & \\
\hline & FS04WV067025Bw & West & Ridge & 60 & 24 & 16 & Sandy Loam & & \\
\hline \multirow[t]{3}{*}{112} & FS04WV067026A & West & Ridge & 36 & 63 & 1 & Silt Loam & & \\
\hline & FS04WV067026BA & West & Ridge & 36 & 47 & 17 & Loam & & \\
\hline & FS04WV067026Bw & West & Ridge & 40 & 45 & 15 & Loam & & \\
\hline \multirow[t]{3}{*}{112} & FS04WV067027A & West & Shoulder & 50 & 32 & 18 & Loam & & \\
\hline & FS04WV067027BA & West & Shoulder & 48 & 36 & 16 & Loam & & \\
\hline & FS04WV067027Bt & West & Shoulder & 43 & 38 & 19 & Loam & & \\
\hline \multirow[t]{3}{*}{113} & FS04WV067028A1 & West & Back slope & 35 & 46 & 19 & Loam & & \\
\hline & FS04WV067028A2 & West & Back slope & 34 & 39 & 27 & Loam & & \\
\hline & FS04WV067028Bw & West & Back slope & 36 & 42 & 22 & Loam & & \\
\hline \multirow[t]{3}{*}{113} & FS04WV067029A & West & Back slope & 34 & 46 & 20 & Loam & & \\
\hline & FS04WV067029BA & West & Back slope & 42 & 39 & 19 & Loam & & \\
\hline & FS04WV067029Bw & West & Back slope & 44 & 37 & 19 & Loam & & \\
\hline \multirow[t]{3}{*}{114} & FS04WV067030A & West & Bench & 30 & 47 & 23 & Loam & & \\
\hline & FS04WV067030BA & West & Bench & 22 & 56 & 22 & Silt Loam & & \\
\hline & FS04WV067030Bt & West & Bench & 20 & 52 & 28 & $\begin{array}{l}\text { Silty Clay } \\
\text { Loam }\end{array}$ & & \\
\hline \multirow[t]{3}{*}{114} & FS04WV067031A & West & Bench & 35 & 45 & 20 & Loam & & \\
\hline & FS04WV067031BA & West & Bench & 33 & 46 & 21 & Loam & & \\
\hline & FS04WV067031Bw & West & Bench & 34 & 45 & 21 & Loam & & \\
\hline \multirow[t]{2}{*}{115} & FS04WV067032A & West & Foot & 51 & 35 & 13 & Loam & & \\
\hline & FS04WV067032Bt & West & Foot & 52 & 27 & 21 & $\begin{array}{l}\text { Sandy Clay } \\
\text { Loam }\end{array}$ & & \\
\hline \multirow[t]{3}{*}{115} & FS04WV025023A & East & Shoulder & 11 & 58 & 31 & $\begin{array}{l}\text { Silty Clay } \\
\text { Loam }\end{array}$ & & \\
\hline & FS04WV025023BA & East & Shoulder & 9 & 54 & 37 & $\begin{array}{l}\text { Silty Clay } \\
\text { Loam }\end{array}$ & & \\
\hline & FS04WV025023Bt & East & Shoulder & 10 & 46 & 44 & Silty Clay & & \\
\hline \multirow[t]{3}{*}{116} & FS04WV025024A & East & Back slope & 33 & 55 & 12 & Silt Loam & & \\
\hline & FS04WV025024BA & East & Back slope & 35 & 34 & 31 & Clay Loam & & \\
\hline & FS04WV025024Bw & East & Back slope & 35 & 41 & 23 & Loam & & \\
\hline
\end{tabular}




\begin{tabular}{|c|c|c|c|c|c|c|c|c|c|}
\hline \multirow[b]{2}{*}{$\begin{array}{l}\text { Descrip. } \\
\text { Page \# }\end{array}$} & \multirow[b]{2}{*}{ Sample ID } & \multirow[b]{2}{*}{$\begin{array}{l}\text { Wshed } \\
\text { Area }\end{array}$} & \multirow[b]{2}{*}{$\begin{array}{l}\text { Landscape } \\
\text { Position }\end{array}$} & \multirow[b]{2}{*}{$\begin{array}{c}\text { Sand } \\
\%\end{array}$} & \multirow[b]{2}{*}{$\begin{array}{l}\text { Silt } \\
\%\end{array}$} & \multirow[b]{2}{*}{$\begin{array}{c}\text { Clay } \\
\%\end{array}$} & \multirow[b]{2}{*}{ Texture } & \multicolumn{2}{|c|}{$\begin{array}{c}\text { Bulk Density } \\
\mathrm{g} \mathrm{cm}^{-3}\end{array}$} \\
\hline & & & & & & & & Clod & Frame \\
\hline \multirow[t]{3}{*}{116} & FS04WV025025A & East & Bench & 35 & 43 & 22 & Loam & & \\
\hline & FS04WV025025BA & East & Bench & 38 & 35 & 27 & Loam & & \\
\hline & FS04WV025025Bt & East & Bench & 36 & 33 & 31 & Clay Loam & & \\
\hline \multirow[t]{3}{*}{117} & FS04WV067033A1 & East & Floodplain & 39 & 37 & 25 & Loam & & \\
\hline & FS04WV067033A2 & East & Floodplain & 43 & 33 & 24 & Loam & & \\
\hline & FS04WV067033BA & East & Floodplain & 44 & 32 & 24 & Loam & & \\
\hline \multirow[t]{3}{*}{117} & FS04WV067034A & East & Back slope & 32 & 53 & 15 & Silt Loam & & \\
\hline & FS04WV067034BA & East & Back slope & 33 & 45 & 22 & Loam & & \\
\hline & FS04WV067034Bt & East & Back slope & 32 & 45 & 23 & Loam & & \\
\hline \multirow[t]{3}{*}{118} & FS04WV101003A & East & Back slope & 33 & 41 & 26 & Loam & & \\
\hline & FS04WV101003BA & East & Back slope & 32 & 35 & 34 & Clay Loam & & \\
\hline & FS04WV101003Bt & East & Back slope & 23 & 43 & 34 & Clay Loam & & \\
\hline \multirow[t]{3}{*}{118} & FS04WV101004A & East & Ridge & 43 & 39 & 18 & Loam & & \\
\hline & FS04WV101004BA & East & Ridge & 38 & 37 & 25 & Loam & & \\
\hline & FS04WV101004Bt & East & Ridge & 12 & 59 & 29 & $\begin{array}{l}\text { Silty Clay } \\
\text { Loam }\end{array}$ & & \\
\hline \multirow[t]{3}{*}{119} & FS04WV101005A1 & East & Bench & 74 & 25 & 1 & Loamy Sand & & \\
\hline & FS04WV101005A2 & East & Bench & 68 & 23 & 10 & Sandy Loam & & \\
\hline & FS04WV101005Ab & East & Bench & 53 & 33 & 14 & Sandy Loam & & \\
\hline \multirow[t]{3}{*}{119} & FS04WV101006A & East & Bench & 18 & 54 & 29 & $\begin{array}{l}\text { Silty Clay } \\
\text { Loam }\end{array}$ & & \\
\hline & FS04WV101006BA & East & Bench & 38 & 39 & 23 & Loam & & \\
\hline & FS04WV101006Bt & East & Bench & 12 & 60 & 29 & $\begin{array}{l}\text { Silty Clay } \\
\text { Loam }\end{array}$ & & \\
\hline \multirow[t]{2}{*}{120} & FS04WV025026A & East & Foot & 37 & 48 & 15 & Loam & & \\
\hline & FS04WV025026BA & East & Foot & 29 & 42 & 29 & Clay Loam & & \\
\hline \multirow[t]{3}{*}{120} & FS04WV025027A & East & Foot & 30 & 50 & 20 & Loam & & \\
\hline & FS04WV025027BA & East & Foot & 27 & 46 & 27 & Clay Loam & & \\
\hline & FS04WV025027Bt & East & Foot & 27 & 41 & 31 & Clay Loam & & \\
\hline \multirow[t]{2}{*}{121} & FS04WV025022A & East & Ridge & 18 & 71 & 11 & Silt Loam & & \\
\hline & FS04WV025022Bt & East & Ridge & 28 & 52 & 19 & Silt Loam & & \\
\hline
\end{tabular}




\section{APPENDIX E \\ ACIDITY AND BUFFERING DATA}

\begin{tabular}{|c|c|c|c|c|c|c|c|}
\hline $\begin{array}{l}\text { Descrip. } \\
\text { Page \# }\end{array}$ & Sample ID & $\begin{array}{l}\text { Wshed } \\
\text { Area }\end{array}$ & $\begin{array}{l}\text { Landscape } \\
\text { Position }\end{array}$ & soil pH & $\begin{array}{c}\text { acidity } \\
\text { meq/100g }\end{array}$ & $\begin{array}{c}\text { ECEC } \\
\mathrm{meq} / 100 \mathrm{~g}\end{array}$ & BSECEC \\
\hline \multirow[t]{8}{*}{69} & FS04WV025001A1 & East & Back slope & 3.6 & 9.6 & 15.6 & 38.3 \\
\hline & FS04WV025001A2 & East & Back slope & 3.4 & 9.6 & 11.5 & 16.4 \\
\hline & FS04WV025001AB & East & Back slope & 3.7 & 12.4 & 13.0 & 4.6 \\
\hline & FS04WV025001Bw1 & East & Back slope & 4.5 & 5.2 & 5.4 & 4.5 \\
\hline & FS04WV025001Bw2 & East & Back slope & 4.6 & 3.6 & 3.8 & 5.9 \\
\hline & FS04WV025001Bw3 & East & Back slope & 4.5 & 3.6 & 3.8 & 5.4 \\
\hline & FS04WV025001Bw4 & East & Back slope & 4.6 & 2.8 & 3.0 & 5.5 \\
\hline & FS04WV025001BC & East & Back slope & 4.7 & 2.4 & 2.6 & 6.5 \\
\hline \multirow[t]{7}{*}{71} & FS04WV025002A & East & Back slope & 3.9 & 10.0 & 12.0 & 16.4 \\
\hline & FS04WV025002AB & East & Back slope & 4.3 & 7.2 & 7.8 & 7.1 \\
\hline & FS04WV025002Bw1 & East & Back slope & 4.5 & 6.0 & 6.3 & 5.2 \\
\hline & FS04WV025002Bw2 & East & Back slope & 4.6 & 5.6 & 6.1 & 7.5 \\
\hline & FS04WV025002Bw3 & East & Back slope & 4.5 & 5.6 & 5.9 & 4.5 \\
\hline & FS04WV025002BC1 & East & Back slope & 4.5 & 5.6 & 5.9 & 4.9 \\
\hline & FS04WV025002BC2 & East & Back slope & 4.6 & 5.2 & 5.4 & 4.5 \\
\hline \multirow[t]{5}{*}{73} & FS04WV025003A & East & Ridge & 3.5 & 13.2 & 14.3 & 7.6 \\
\hline & FS04WV025003Bw1 & East & Ridge & 4.1 & 10.0 & 10.4 & 3.8 \\
\hline & FS04WV025003Bw2 & East & Ridge & 4.5 & 6.0 & 6.2 & 3.8 \\
\hline & FS04WV025003Bx1 & East & Ridge & 4.5 & 4.4 & 4.6 & 5.0 \\
\hline & FS04WV025003Bx2 & East & Ridge & 4.5 & 6.4 & 6.7 & 3.8 \\
\hline \multirow[t]{8}{*}{75} & FS04WV025004A & East & Foot & 3.5 & 7.2 & 9.1 & 20.4 \\
\hline & FS04WV025004AB & East & Foot & 3.6 & 9.2 & 9.9 & 6.8 \\
\hline & FS04WV025004Bw1 & East & Foot & 4.2 & 6.0 & 6.3 & 5.2 \\
\hline & FS04WV025004Bw2 & East & Foot & 4.6 & 2.8 & 3.0 & 6.4 \\
\hline & FS04WV025004Bw3 & East & Foot & 4.5 & 2.8 & 3.0 & 7.0 \\
\hline & FS04WV025004Bw4 & East & Foot & 4.6 & 3.6 & 3.8 & 6.2 \\
\hline & FS04WV025004Bx & East & Foot & 4.7 & 4.0 & 4.3 & 6.0 \\
\hline & FS04WV025004BC & East & Foot & 4.7 & 3.6 & 3.9 & 7.3 \\
\hline \multirow[t]{7}{*}{77} & FS04WV025005A & East & Bench & 3.5 & 11.6 & 13.1 & 11.6 \\
\hline & FS04WV025005AB & East & Bench & 3.7 & 16.4 & 17.0 & 3.6 \\
\hline & FS04WV025005Bw1 & East & Bench & 4.4 & 6.4 & 6.7 & 4.7 \\
\hline & FS04WV025005Bw2 & East & Bench & 4.5 & 5.2 & 5.4 & 4.4 \\
\hline & FS04WV025005Bx1 & East & Bench & 4.5 & 5.2 & 5.4 & 4.4 \\
\hline & FS04WV025005Bx2 & East & Bench & 4.6 & 4.8 & 5.0 & 4.6 \\
\hline & FS04WV025005Bx3 & East & Bench & 4.6 & 7.2 & 7.6 & 5.7 \\
\hline
\end{tabular}




\begin{tabular}{|c|c|c|c|c|c|c|c|}
\hline $\begin{array}{l}\text { Descrip. } \\
\text { Page \# }\end{array}$ & Sample ID & $\begin{array}{l}\text { Wshed } \\
\text { Area }\end{array}$ & $\begin{array}{l}\text { Landscape } \\
\text { Position }\end{array}$ & soil pH & $\begin{array}{c}\text { acidity } \\
\text { meq/100g }\end{array}$ & $\begin{array}{c}\text { ECEC } \\
\mathrm{meq} / 100 \mathrm{~g}\end{array}$ & BSECEC \\
\hline & FS04WV025005BC & East & Bench & 4.5 & 6.8 & 7.3 & 6.7 \\
\hline \multirow[t]{6}{*}{79} & FS04WV025010A/E & East & Shoulder & 3.5 & 10.8 & 13.0 & 17.0 \\
\hline & FS04WV025010BA & East & Shoulder & 4.1 & 8.8 & 9.3 & 5.6 \\
\hline & FS04WV025010Bt & East & Shoulder & 4.4 & 5.6 & 5.9 & 5.3 \\
\hline & FS04WV025010Btx1 & East & Shoulder & 4.6 & 4.8 & 5.2 & 6.9 \\
\hline & FS04WV025010Btx2 & East & Shoulder & 4.6 & 5.6 & 6.0 & 6.0 \\
\hline & FS04WV025010BC & East & Shoulder & 4.5 & 5.2 & 5.6 & 7.0 \\
\hline \multirow[t]{5}{*}{81} & FS04WV025019A & East & Floodplain & 3.9 & 7.2 & 8.3 & 13.7 \\
\hline & FS04WV025019Bw1 & East & Floodplain & 4.2 & 4.8 & 5.4 & 10.5 \\
\hline & FS04WV025019Bw2 & East & Floodplain & 4.3 & 4.8 & 5.4 & 10.8 \\
\hline & FS04WV025019Bw3 & East & Floodplain & 4.6 & 3.6 & 4.2 & 13.3 \\
\hline & FS04WV025019BC & East & Floodplain & 4.7 & 2.8 & 3.6 & 22.1 \\
\hline \multirow[t]{5}{*}{83} & FS04WV101001A & East & Ridge & 3.4 & 9.2 & 11.7 & 21.4 \\
\hline & FS04WV101001BA & East & Ridge & 3.6 & 13.6 & 14.4 & 5.9 \\
\hline & FS04WV101001Bt1 & East & Ridge & 4.5 & 5.6 & 5.8 & 3.9 \\
\hline & FS04WV101001Bt2 & East & Ridge & 4.3 & 9.2 & 9.6 & 3.7 \\
\hline & FS04WV101001Bt3 & East & Ridge & 4.5 & 5.6 & 5.8 & 3.4 \\
\hline \multirow[t]{6}{*}{84} & FS04WV067007A & East & Shoulder & 3.7 & 11.2 & 11.8 & 5.3 \\
\hline & FS04WV067007BA & East & Shoulder & 4.5 & 6.4 & 6.7 & 4.2 \\
\hline & FS04WV067007Bw1 & East & Shoulder & 4.6 & 3.2 & 3.4 & 5.9 \\
\hline & FS04WV067007Bw2 & East & Shoulder & 4.6 & 3.2 & 3.3 & 3.9 \\
\hline & FS04WV067007Bw3 & East & Shoulder & 4.6 & 3.6 & 3.7 & 3.4 \\
\hline & FS04WV067007BC & East & Shoulder & 4.5 & 4.0 & 4.2 & 3.6 \\
\hline \multirow[t]{7}{*}{85} & FS04WV067001A & West & Back slope & 4.3 & 5.6 & 7.7 & 27.1 \\
\hline & FS04WV067001AB & West & Back slope & 4.6 & 2.8 & 3.1 & 8.6 \\
\hline & FS04WV067001Bw1 & West & Back slope & 4.6 & 2.8 & 3.0 & 7.1 \\
\hline & FS04WV067001Bw2 & West & Back slope & 4.6 & 3.6 & 3.8 & 5.4 \\
\hline & FS04WV067001Bw3 & West & Back slope & 4.5 & 2.8 & 3.0 & 6.2 \\
\hline & FS04WV067001BC & West & Back slope & 4.5 & 2.4 & 2.6 & 7.3 \\
\hline & FS04WV067001C & West & Back slope & 4.5 & 1.6 & 1.8 & 9.1 \\
\hline \multirow[t]{4}{*}{87} & FS04WV067002A & West & Ridge & 3.9 & 5.6 & 6.1 & 7.5 \\
\hline & FS04WV067002BA & West & Ridge & 4.6 & 3.2 & 3.4 & 5.5 \\
\hline & FS04WV067002Bw1 & West & Ridge & 4.8 & 2.8 & 3.1 & 10.8 \\
\hline & FS04WV067002Bw2 & West & Ridge & 4.5 & 2.8 & 3.0 & 6.1 \\
\hline \multirow[t]{2}{*}{88} & FS04WV067003A & West & Ridge & 3.9 & 6.8 & 9.2 & 25.7 \\
\hline & FS04WV067003AB & West & Ridge & 4.3 & 5.2 & 6.0 & 13.7 \\
\hline
\end{tabular}




\begin{tabular}{|c|c|c|c|c|c|c|c|}
\hline $\begin{array}{l}\text { Descrip. } \\
\text { Page \# }\end{array}$ & Sample ID & $\begin{array}{l}\text { Wshed } \\
\text { Area }\end{array}$ & $\begin{array}{l}\text { Landscape } \\
\text { Position }\end{array}$ & soil pH & $\begin{array}{l}\text { acidity } \\
\text { meq/100g }\end{array}$ & $\begin{array}{c}\text { ECEC } \\
\mathrm{meq} / 100 \mathrm{~g}\end{array}$ & BSECEC \\
\hline & FS04WV067003Bw1 & West & Ridge & 4.4 & 4.4 & 4.9 & 9.6 \\
\hline & FS04WV067003Bw2 & West & Ridge & 4.5 & 3.6 & 3.9 & 8.4 \\
\hline & FS04WV067003BC & West & Ridge & 4.5 & 3.6 & 3.9 & 7.3 \\
\hline \multirow[t]{8}{*}{89} & FS04WV067004A & West & Floodplain & 4.1 & 4.4 & 5.3 & 17.7 \\
\hline & FS04WV067004BA & West & Floodplain & 4.3 & 4.0 & 4.3 & 6.9 \\
\hline & FS04WV067004Bw1 & West & Floodplain & 4.6 & 3.2 & 3.4 & 5.2 \\
\hline & FS04WV067004Bw2 & West & Floodplain & 4.6 & 4.8 & 5.0 & 4.9 \\
\hline & FS04WV067004Ab & West & Floodplain & 4.5 & 3.2 & 3.6 & 10.9 \\
\hline & FS04WV067004C1 & West & Floodplain & 4.8 & 1.6 & 2.1 & 25.3 \\
\hline & FS04WV067004C2 & West & Floodplain & 4.8 & 0.8 & 1.1 & 26.5 \\
\hline & FS04WV067004C3 & West & Floodplain & 5.1 & 0.4 & 1.6 & 75.0 \\
\hline \multirow[t]{8}{*}{91} & FS04WV067005A & West & Bench & 3.9 & 8.4 & 9.5 & 11.1 \\
\hline & FS04WV067005AB & West & Bench & 4.0 & 6.8 & 7.3 & 6.2 \\
\hline & FS04WV067005Bw1 & West & Bench & 4.4 & 4.0 & 4.2 & 5.3 \\
\hline & FS04WV067005Bw2 & West & Bench & 4.6 & 4.0 & 4.2 & 5.7 \\
\hline & FS04WV067005Bw3 & West & Bench & 4.6 & 4.0 & 4.3 & 7.9 \\
\hline & FS04WV067005Bx1 & West & Bench & 4.7 & 3.6 & 4.1 & 11.5 \\
\hline & FS04WV067005Bx2 & West & Bench & 4.5 & 4.8 & 5.2 & 7.8 \\
\hline & FS04WV067005BC & West & Bench & 4.6 & 3.6 & 4.1 & 12.1 \\
\hline \multirow[t]{6}{*}{93} & FS04WV067006A & West & Foot & 4.0 & 8.4 & 10.0 & 16.3 \\
\hline & FS04WV067006AB & West & Foot & 4.2 & 7.2 & 7.9 & 8.4 \\
\hline & FS04WV067006Bw1 & West & Foot & 4.6 & 5.2 & 5.5 & 6.3 \\
\hline & FS04WV067006Bw2 & West & Foot & 4.6 & 4.8 & 5.2 & 7.9 \\
\hline & FS04WV067006Bw3 & West & Foot & 4.8 & 4.0 & 4.7 & 15.1 \\
\hline & FS04WV067006BC & West & Foot & 4.7 & 3.6 & 4.3 & 16.6 \\
\hline \multirow[t]{6}{*}{95} & FS04WV067017A & West & Shoulder & 4.1 & 7.2 & 7.6 & 5.5 \\
\hline & FS04WV067017AE & West & Shoulder & 4.5 & 4.4 & 4.7 & 6.2 \\
\hline & FS04WV067017BA & West & Shoulder & 4.6 & 3.6 & 3.8 & 5.8 \\
\hline & FS04WV067017Bw1 & West & Shoulder & 4.5 & 4.0 & 4.2 & 4.2 \\
\hline & FS04WV067017BC & West & Shoulder & 4.4 & 3.2 & 3.4 & 5.0 \\
\hline & FS04WV067017C & West & Shoulder & 4.4 & 3.6 & 3.7 & 3.7 \\
\hline \multirow[t]{3}{*}{96} & FS04WV025006A & East & Back slope & 3.3 & 7.2 & 8.3 & 13.4 \\
\hline & FS04WV025006BA & East & Back slope & 3.6 & 10.4 & 10.8 & 3.9 \\
\hline & FS04WV025006Bt & East & Back slope & 4.2 & 6.4 & 6.7 & 4.2 \\
\hline \multirow[t]{3}{*}{96} & FS04WV025007A & East & Bench & 3.6 & 8.0 & 9.5 & 15.9 \\
\hline & FS04WV025007BA & East & Bench & 4.4 & 4.0 & 4.3 & 7.2 \\
\hline & FS04WV025007Bw & East & Bench & 4.5 & 4.4 & 4.8 & 8.6 \\
\hline
\end{tabular}




\begin{tabular}{|c|c|c|c|c|c|c|c|}
\hline $\begin{array}{l}\text { Descrip. } \\
\text { Page \# }\end{array}$ & Sample ID & $\begin{array}{l}\text { Wshed } \\
\text { Area }\end{array}$ & $\begin{array}{l}\text { Landscape } \\
\text { Position }\end{array}$ & soil pH & $\begin{array}{c}\text { acidity } \\
\text { meq/100g }\end{array}$ & $\begin{array}{c}\text { ECEC } \\
\mathrm{meq} / 100 \mathrm{~g}\end{array}$ & BSECEC \\
\hline \multirow{2}{*}{97} & FS04WV025008A & East & Floodplain & 3.5 & 15.6 & 18.0 & 13.3 \\
\hline & FS04WV025008Bt & East & Floodplain & 3.9 & 11.6 & 12.1 & 4.2 \\
\hline \multirow[t]{2}{*}{97} & FS04WV025009A & East & Foot & 3.8 & 8.8 & 9.8 & 10.6 \\
\hline & FS04WV025009Bt & East & Foot & 4.2 & 6.4 & 6.8 & 6.4 \\
\hline \multirow[t]{3}{*}{98} & FS04WV025011A & East & Shoulder & 3.8 & 8.4 & 9.7 & 13.0 \\
\hline & FS04WV025011BA & East & Shoulder & 4.1 & 7.2 & 7.8 & 7.2 \\
\hline & FS04WV025011Bt & East & Shoulder & 4.4 & 5.6 & 6.0 & 6.8 \\
\hline \multirow[t]{2}{*}{98} & FS04WV025012A & East & Bench & 3.8 & 10.8 & 11.4 & 5.3 \\
\hline & FS04WV025012Bw & East & Bench & 4.6 & 4.4 & 4.6 & 5.3 \\
\hline \multirow[t]{3}{*}{99} & FS04WV025013A & East & Ridge & 3.4 & 5.2 & 7.4 & 29.5 \\
\hline & FS04WV025013BA & East & Ridge & 3.6 & 8.4 & 8.8 & 4.3 \\
\hline & FS04WV025013Bt & East & Ridge & 4.1 & 9.6 & 9.9 & 2.7 \\
\hline \multirow[t]{3}{*}{99} & FS04WV025014A & East & Back slope & 3.8 & 9.2 & 10.5 & 12.6 \\
\hline & FS04WV025014BA & East & Back slope & 4.4 & 7.2 & 7.6 & 5.8 \\
\hline & FS04WV025014Bt & East & Back slope & 4.6 & 6.8 & 7.3 & 6.7 \\
\hline \multirow[t]{2}{*}{100} & FS04WV025015A & East & Shoulder & 3.4 & 10.0 & 11.1 & 9.7 \\
\hline & FS04WV025015Bt & East & Shoulder & 4.1 & 11.6 & 11.9 & 2.4 \\
\hline \multirow[t]{3}{*}{100} & FS04WV067008A & West & Foot & 3.9 & 6.8 & 7.8 & 13.0 \\
\hline & FS04WV067008BA & West & Foot & 4.2 & 6.8 & 7.2 & 5.1 \\
\hline & FS04WV067008Bw & West & Foot & 4.3 & 6.0 & 6.3 & 4.9 \\
\hline \multirow[t]{3}{*}{101} & FS04WV067009A & West & Floodplain & 4.0 & 3.6 & 4.4 & 17.6 \\
\hline & FS04WV067009BA & West & Floodplain & 4.1 & 1.6 & 1.8 & 10.4 \\
\hline & FS04WV067009Bw & West & Floodplain & 4.1 & 2.0 & 2.2 & 8.7 \\
\hline \multirow[t]{3}{*}{101} & FS04WV067010A & West & Back slope & 4.3 & 4.8 & 5.9 & 18.6 \\
\hline & FS04WV067010BA & West & Back slope & 4.6 & 2.8 & 3.3 & 14.1 \\
\hline & FS04WV067010Bw & West & Back slope & 4.6 & 2.8 & 3.3 & 15.0 \\
\hline \multirow[t]{2}{*}{102} & FS04WV067011BA & West & Floodplain & 4.4 & 2.4 & 2.7 & 12.3 \\
\hline & FS04WV067011Bw & West & Floodplain & 4.5 & 1.6 & 1.8 & 9.5 \\
\hline \multirow[t]{3}{*}{102} & FS04WV067012A & West & Ridge & 3.9 & 9.2 & 10.5 & 12.5 \\
\hline & FS04WV067012BA & West & Ridge & 4.3 & 6.0 & 6.5 & 7.7 \\
\hline & FS04WV067012Bw & West & Ridge & 4.4 & 6.4 & 6.8 & 6.4 \\
\hline
\end{tabular}




\begin{tabular}{|c|c|c|c|c|c|c|c|}
\hline $\begin{array}{l}\text { Descrip. } \\
\text { Page \# }\end{array}$ & Sample ID & $\begin{array}{l}\text { Wshed } \\
\text { Area }\end{array}$ & $\begin{array}{l}\text { Landscape } \\
\text { Position }\end{array}$ & soil pH & $\begin{array}{c}\text { acidity } \\
\text { meq/100g }\end{array}$ & $\begin{array}{c}\text { ECEC } \\
\mathrm{meq} / 100 \mathrm{~g}\end{array}$ & BSECEC \\
\hline \multirow{3}{*}{103} & FS04WV067013A & West & Back slope & 3.8 & 7.2 & 8.5 & 15.0 \\
\hline & FS04WV067013BA & West & Back slope & 4.5 & 2.8 & 3.0 & 7.5 \\
\hline & FS04WV067013Bw & West & Back slope & 4.6 & 2.4 & 2.6 & 6.9 \\
\hline \multirow[t]{3}{*}{103} & FS04WV067014A & West & Bench & 4.0 & 5.2 & 7.4 & 29.8 \\
\hline & FS04WV067014BA & West & Bench & 4.4 & 4.0 & 4.5 & 11.1 \\
\hline & FS04WV067014Bw & West & Bench & 4.4 & 4.4 & 4.8 & 8.6 \\
\hline \multirow[t]{3}{*}{104} & FS04WV067015A & West & Shoulder & 4.1 & 5.6 & 6.8 & 17.6 \\
\hline & FS04WV067015BA & West & Shoulder & 4.2 & 4.8 & 5.4 & 10.7 \\
\hline & FS04WV067015Bw & West & Shoulder & 4.6 & 3.6 & 4.0 & 9.0 \\
\hline \multirow[t]{3}{*}{104} & FS04WV067016A & West & Ridge & 4.0 & 4.8 & 6.3 & 23.6 \\
\hline & FS04WV067016BA & West & Ridge & 4.4 & 3.2 & 3.5 & 9.6 \\
\hline & FS04WV067016Bt & West & Ridge & 4.5 & 3.6 & 3.8 & 6.1 \\
\hline \multirow[t]{3}{*}{105} & FS04WV025016A1 & East & Floodplain & 3.7 & 10.8 & 12.3 & 11.9 \\
\hline & FS04WV025016A2 & East & Floodplain & 3.8 & 14.4 & 15.0 & 3.8 \\
\hline & FS04WV025016Bw & East & Floodplain & 4.2 & 9.2 & 9.4 & 2.1 \\
\hline \multirow[t]{3}{*}{105} & FS04WV025017A & East & Back slope & 3.6 & 8.8 & 9.9 & 11.1 \\
\hline & FS04WV025017BA & East & Back slope & 4.1 & 12.4 & 12.8 & 2.9 \\
\hline & FS04WV025017Bt & East & Back slope & 4.4 & 10.4 & 10.8 & 3.4 \\
\hline \multirow[t]{2}{*}{106} & FS04WV025018A & East & Foot & 3.7 & 12.8 & 13.7 & 6.4 \\
\hline & FS04WV025018Bw & East & Foot & 4.1 & 8.4 & 8.6 & 2.7 \\
\hline \multirow[t]{3}{*}{106} & FS04WV067018A & West & Foot & 3.9 & 4.8 & 5.6 & 13.6 \\
\hline & FS04WV067018BA & West & Foot & 4.3 & 3.6 & 3.8 & 6.4 \\
\hline & FS04WV067018Bt & West & Foot & 4.6 & 2.8 & 3.0 & 5.7 \\
\hline \multirow[t]{3}{*}{107} & FS04WV067019A & West & Bench & 4.1 & 6.0 & 7.0 & 14.3 \\
\hline & FS04WV067019BA & West & Bench & 4.4 & 4.8 & 5.1 & 6.5 \\
\hline & FS04WV067019Bw & West & Bench & 4.6 & 4.0 & 4.3 & 6.2 \\
\hline \multirow[t]{3}{*}{107} & FS04WV067020A & West & Shoulder & 3.7 & 6.0 & 6.7 & 10.4 \\
\hline & FS04WV067020BA & West & Shoulder & 4.4 & 4.4 & 4.6 & 5.2 \\
\hline & FS04WV067020Bt & West & Shoulder & 4.5 & 2.8 & 3.0 & 7.8 \\
\hline \multirow[t]{3}{*}{108} & FS04WV067021A & West & Ridge & 3.9 & 6.0 & 7.1 & 14.8 \\
\hline & FS04WV067021BA & West & Ridge & 4.4 & 3.6 & 4.1 & 11.2 \\
\hline & FS04WV067021Bw & West & Ridge & 4.5 & 3.2 & 3.4 & 6.7 \\
\hline
\end{tabular}




\begin{tabular}{|c|c|c|c|c|c|c|c|}
\hline $\begin{array}{l}\text { Descrip. } \\
\text { Page \# }\end{array}$ & Sample ID & $\begin{array}{l}\text { Wshed } \\
\text { Area }\end{array}$ & $\begin{array}{l}\text { Landscape } \\
\text { Position }\end{array}$ & soil pH & $\begin{array}{c}\text { acidity } \\
\text { meq/100g }\end{array}$ & $\begin{array}{c}\text { ECEC } \\
\mathrm{meq} / 100 \mathrm{~g}\end{array}$ & BSECEC \\
\hline \multirow[t]{3}{*}{108} & FS04WV067022A1 & West & Shoulder & 3.6 & 2.8 & 3.4 & 17.5 \\
\hline & FS04WV067022A2 & West & Shoulder & 3.6 & 2.4 & 2.6 & 6.9 \\
\hline & FS04WV067022AB & West & Shoulder & 3.8 & 3.6 & 3.8 & 6.0 \\
\hline \multirow[t]{3}{*}{109} & FS04WV067023A & West & Ridge & 3.9 & 9.6 & 10.7 & 10.0 \\
\hline & FS04WV067023BA & West & Ridge & 4.3 & 6.0 & 6.3 & 5.3 \\
\hline & FS04WV067023Bw & West & Ridge & 4.5 & 5.2 & 5.5 & 4.9 \\
\hline \multirow[t]{2}{*}{109} & FS04WV067024BA & West & Back slope & 4.4 & 6.8 & 7.5 & 9.4 \\
\hline & FS04WV067024Bt & West & Back slope & 4.5 & 5.2 & 5.6 & 6.9 \\
\hline \multirow[t]{3}{*}{110} & FS04WV025020A & East & Bench & 4.2 & 4.0 & 5.0 & 19.9 \\
\hline & FS04WV025020BA & East & Bench & 4.5 & 3.6 & 4.0 & 9.2 \\
\hline & FS04WV025020Bt & East & Bench & 4.6 & 4.0 & 4.3 & 7.2 \\
\hline \multirow[t]{3}{*}{110} & FS04WV025021A & East & Back slope & 3.5 & 8.4 & 10.0 & 16.2 \\
\hline & FS04WV025021BA & East & Back slope & 3.9 & 8.4 & 9.0 & 6.2 \\
\hline & FS04WV025021Bw & East & Back slope & 4.3 & 8.0 & 8.4 & 4.9 \\
\hline \multirow[t]{3}{*}{111} & FS04WV101002A & East & Ridge & 3.9 & 7.2 & 8.6 & 15.7 \\
\hline & FS04WV101002BA & East & Ridge & 4.3 & 6.8 & 8.1 & 15.7 \\
\hline & FS04WV101002Bt & East & Ridge & 4.6 & 6.4 & 7.7 & 17.2 \\
\hline \multirow[t]{3}{*}{111} & FS04WV067025A & West & Ridge & 4.2 & 6.4 & 6.8 & 5.9 \\
\hline & FS04WV067025BA & West & Ridge & 4.5 & 4.0 & 4.2 & 5.4 \\
\hline & FS04WV067025Bw & West & Ridge & 4.6 & 3.2 & 3.3 & 3.6 \\
\hline \multirow[t]{3}{*}{112} & FS04WV067026A & West & Ridge & 3.1 & 14.0 & 15.1 & 7.1 \\
\hline & FS04WV067026BA & West & Ridge & 4.3 & 9.6 & 10.0 & 4.3 \\
\hline & FS04WV067026Bw & West & Ridge & 4.4 & 5.6 & 5.9 & 4.4 \\
\hline \multirow[t]{3}{*}{112} & FS04WV067027A & West & Shoulder & 4.1 & 7.2 & 7.7 & 6.9 \\
\hline & FS04WV067027BA & West & Shoulder & 4.5 & 4.8 & 5.1 & 5.1 \\
\hline & FS04WV067027Bt & West & Shoulder & 4.7 & 3.2 & 3.5 & 7.5 \\
\hline \multirow[t]{3}{*}{113} & FS04WV067028A1 & West & Back slope & 4.0 & 7.2 & 7.9 & 9.4 \\
\hline & FS04WV067028A2 & West & Back slope & 4.4 & 4.8 & 5.2 & 7.4 \\
\hline & FS04WV067028Bw & West & Back slope & 4.7 & 3.6 & 3.8 & 6.0 \\
\hline \multirow[t]{3}{*}{113} & FS04WV067029A & West & Back slope & 4.4 & 7.2 & 7.8 & 7.7 \\
\hline & FS04WV067029BA & West & Back slope & 4.6 & 4.0 & 4.3 & 6.8 \\
\hline & FS04WV067029Bw & West & Back slope & 4.7 & 3.6 & 3.9 & 7.7 \\
\hline
\end{tabular}




\begin{tabular}{|c|c|c|c|c|c|c|c|}
\hline $\begin{array}{l}\text { Descrip. } \\
\text { Page \# }\end{array}$ & Sample ID & $\begin{array}{l}\text { Wshed } \\
\text { Area }\end{array}$ & $\begin{array}{l}\text { Landscape } \\
\text { Position }\end{array}$ & soil pH & $\begin{array}{c}\text { acidity } \\
\text { meq/100g }\end{array}$ & $\begin{array}{c}\text { ECEC } \\
\mathrm{meq} / 100 \mathrm{~g}\end{array}$ & BSECEC \\
\hline \multirow[t]{3}{*}{114} & FS04WV067030A & West & Bench & 4.2 & 4.8 & 7.5 & 36.3 \\
\hline & FS04WV067030BA & West & Bench & 4.6 & 5.2 & 6.0 & 12.7 \\
\hline & FS04WV067030Bt & West & Bench & 4.7 & 4.4 & 4.9 & 9.7 \\
\hline \multirow[t]{3}{*}{114} & FS04WV067031A & West & Bench & 4.2 & 6.8 & 7.7 & 11.9 \\
\hline & FS04WV067031BA & West & Bench & 4.2 & 5.2 & 5.5 & 6.2 \\
\hline & FS04WV067031Bw & West & Bench & 4.6 & 4.0 & 4.2 & 5.8 \\
\hline \multirow[t]{2}{*}{115} & FS04WV067032A & West & Foot & 4.2 & 7.6 & 8.8 & 13.7 \\
\hline & FS04WV067032Bt & West & Foot & 4.4 & 4.0 & 4.2 & 5.2 \\
\hline \multirow[t]{3}{*}{115} & FS04WV025023A & East & Shoulder & 4.3 & 9.2 & 9.8 & 6.5 \\
\hline & FS04WV025023BA & East & Shoulder & 4.4 & 8.0 & 8.4 & 5.0 \\
\hline & FS04WV025023Bt & East & Shoulder & 4.5 & 8.0 & 8.4 & 4.5 \\
\hline \multirow[t]{3}{*}{116} & FS04WV025024A & East & Back slope & 3.8 & 10.4 & 11.1 & 6.2 \\
\hline & FS04WV025024BA & East & Back slope & 4.3 & 6.0 & 6.2 & 3.8 \\
\hline & FS04WV025024Bw & East & Back slope & 4.4 & 6.0 & 6.3 & 4.4 \\
\hline \multirow[t]{3}{*}{116} & FS04WV025025A & East & Bench & 3.8 & 12.0 & 12.8 & 5.9 \\
\hline & FS04WV025025BA & East & Bench & 4.1 & 9.2 & 9.6 & 3.9 \\
\hline & FS04WV025025Bt & East & Bench & 4.2 & 8.4 & 8.7 & 3.9 \\
\hline \multirow[t]{3}{*}{117} & FS04WV067033A1 & East & Floodplain & 3.9 & 11.2 & 12.2 & 8.4 \\
\hline & FS04WV067033A2 & East & Floodplain & 4.1 & 10.0 & 10.6 & 5.3 \\
\hline & FS04WV067033BA & East & Floodplain & 4.2 & 8.8 & 9.3 & 5.4 \\
\hline \multirow[t]{3}{*}{117} & FS04WV067034A & East & Back slope & 4.1 & 10.4 & 10.9 & 4.8 \\
\hline & FS04WV067034BA & East & Back slope & 4.3 & 8.0 & 8.3 & 3.9 \\
\hline & FS04WV067034Bt & East & Back slope & 4.5 & 3.6 & 3.8 & 5.5 \\
\hline \multirow[t]{3}{*}{118} & FS04WV101003A & East & Back slope & 4.2 & 8.4 & 10.1 & 16.4 \\
\hline & FS04WV101003BA & East & Back slope & 4.4 & 6.4 & 7.1 & 9.2 \\
\hline & FS04WV101003Bt & East & Back slope & 4.7 & 4.4 & 4.8 & 7.5 \\
\hline \multirow[t]{3}{*}{118} & FS04WV101004A & East & Ridge & 3.5 & 9.6 & 10.6 & 9.3 \\
\hline & FS04WV101004BA & East & Ridge & 4.1 & 7.6 & 8.0 & 4.6 \\
\hline & FS04WV101004Bt & East & Ridge & 4.3 & 6.8 & 7.1 & 4.6 \\
\hline \multirow[t]{3}{*}{119} & FS04WV101005A1 & East & Bench & 3.9 & 3.2 & 3.5 & 9.2 \\
\hline & FS04WV101005A2 & East & Bench & 4.0 & 4.8 & 5.1 & 5.0 \\
\hline & FS04WV101005Ab & East & Bench & 4.0 & 5.6 & 6.0 & 6.4 \\
\hline
\end{tabular}




\begin{tabular}{|c|c|c|c|c|c|c|c|}
\hline $\begin{array}{l}\text { Descrip. } \\
\text { Page \# }\end{array}$ & Sample ID & $\begin{array}{l}\text { Wshed } \\
\text { Area }\end{array}$ & $\begin{array}{l}\text { Landscape } \\
\text { Position }\end{array}$ & soil pH & $\begin{array}{c}\text { acidity } \\
\text { meq/100g }\end{array}$ & $\begin{array}{c}\text { ECEC } \\
\mathrm{meq} / 100 \mathrm{~g}\end{array}$ & BSECEC \\
\hline \multirow{3}{*}{119} & FS04WV101006A & East & Bench & 4.0 & 9.2 & 10.1 & 8.5 \\
\hline & FS04WV101006BA & East & Bench & 4.3 & 9.2 & 9.8 & 5.6 \\
\hline & FS04WV101006Bt & East & Bench & 4.3 & 8.0 & 8.6 & 6.9 \\
\hline \multirow[t]{3}{*}{120} & FS04WV025026A & East & Foot & 3.4 & 7.2 & 8.1 & 10.7 \\
\hline & FS04WV025026BA & East & Foot & 4.0 & 10.0 & 10.3 & 2.8 \\
\hline & FS04WV025026Bt & East & Foot & 4.2 & 8.8 & 9.1 & 3.2 \\
\hline \multirow[t]{3}{*}{120} & FS04WV025027A & East & Foot & 4.0 & 9.6 & 10.5 & 8.6 \\
\hline & FS04WV025027BA & East & Foot & 4.3 & 7.6 & 8.0 & 4.5 \\
\hline & FS04WV025027Bt & East & Foot & 4.5 & 7.2 & 7.5 & 4.3 \\
\hline \multirow[t]{2}{*}{121} & FS04WV025022A & East & Ridge & 3.4 & 6.0 & 8.4 & 28.4 \\
\hline & FS04WV025022Bt & East & Ridge & 4.4 & 5.2 & 5.7 & 9.2 \\
\hline
\end{tabular}


APPENDIX F

BASE CATION DATA

\begin{tabular}{|c|c|c|c|c|c|c|c|}
\hline $\begin{array}{l}\text { Descrip. } \\
\text { Page \# }\end{array}$ & Sample ID & $\begin{array}{l}\text { Wshed } \\
\text { Area }\end{array}$ & $\begin{array}{l}\text { Landscape } \\
\text { Position }\end{array}$ & $\mathrm{Ca}$ & Mg & $\mathbf{K}$ & $\mathrm{Na}$ \\
\hline & & & & \multicolumn{4}{|c|}{$\mathrm{mg} / \mathrm{kg}$} \\
\hline \multirow[t]{8}{*}{69} & FS04WV025001A1 & East & Back slope & 905 & 95.1 & 206 & 35 \\
\hline & FS04WV025001A2 & East & Back slope & 257 & 37.6 & 93 & 13 \\
\hline & FS04WV025001AB & East & Back slope & 57 & 14.5 & 57 & 10 \\
\hline & FS04WV025001Bw1 & East & Back slope & 17 & 4.3 & 34 & 8 \\
\hline & FS04WV025001Bw2 & East & Back slope & 18 & 4.1 & 26 & 8 \\
\hline & FS04WV025001Bw3 & East & Back slope & 16 & 3.9 & 23 & 7 \\
\hline & FS04WV025001Bw4 & East & Back slope & 15 & 3.1 & 15 & 6 \\
\hline & FS04WV025001BC & East & Back slope & 14 & 3.6 & 15 & 6 \\
\hline \multirow[t]{7}{*}{71} & FS04WV025002A & East & Back slope & 261 & 40.1 & 97 & 19 \\
\hline & FS04WV025002AB & East & Back slope & 49 & 11.3 & 56 & 16 \\
\hline & FS04WV025002Bw1 & East & Back slope & 24 & 6.8 & 42 & 11 \\
\hline & FS04WV025002Bw2 & East & Back slope & 44 & 8.7 & 40 & 15 \\
\hline & FS04WV025002Bw3 & East & Back slope & 20 & 4.7 & 34 & 9 \\
\hline & FS04WV025002BC1 & East & Back slope & 22 & 5.9 & 34 & 10 \\
\hline & FS04WV025002BC2 & East & Back slope & 18 & 4.2 & 36 & 7 \\
\hline \multirow[t]{5}{*}{73} & FS04WV025003A & East & Ridge & 110 & 30.8 & 83 & 15 \\
\hline & FS04WV025003Bw1 & East & Ridge & 24 & 10.4 & 54 & 11 \\
\hline & FS04WV025003Bw2 & East & Ridge & 15 & 4.7 & 37 & 7 \\
\hline & FS04WV025003Bx1 & East & Ridge & 13 & 4.1 & 41 & 6 \\
\hline & FS04WV025003Bx2 & East & Ridge & 13 & 4.8 & 52 & 4 \\
\hline \multirow[t]{8}{*}{75} & FS04WV025004A & East & Foot & 227 & 44.7 & 114 & 13 \\
\hline & FS04WV025004AB & East & Foot & 62 & 20.0 & 61 & 11 \\
\hline & FS04WV025004Bw1 & East & Foot & 26 & 8.0 & 37 & 9 \\
\hline & FS04WV025004Bw2 & East & Foot & 16 & 3.8 & 20 & 7 \\
\hline & FS04WV025004Bw3 & East & Foot & 17 & 4.0 & 28 & 5 \\
\hline & FS04WV025004Bw4 & East & Foot & 17 & 4.4 & 37 & 5 \\
\hline & FS04WV025004Bx & East & Foot & 20 & 4.5 & 41 & 4 \\
\hline & FS04WV025004BC & East & Foot & 24 & 4.4 & 40 & 6 \\
\hline \multirow[t]{8}{*}{77} & FS04WV025005A & East & Bench & 146 & 53.1 & 118 & 13 \\
\hline & FS04WV025005AB & East & Bench & 44 & 21.0 & 69 & 11 \\
\hline & FS04WV025005Bw1 & East & Bench & 24 & 7.2 & 38 & 10 \\
\hline & FS04WV025005Bw2 & East & Bench & 18 & 4.5 & 33 & 7 \\
\hline & FS04WV025005Bx1 & East & Bench & 17 & 4.8 & 33 & 7 \\
\hline & FS04WV025005Bx2 & East & Bench & 17 & 4.3 & 33 & 6 \\
\hline & FS04WV025005B×3 & East & Bench & 23 & 9.7 & 83 & 6 \\
\hline & FS04WV025005BC & East & Bench & 26 & 12.9 & 90 & 5 \\
\hline
\end{tabular}




\begin{tabular}{|c|c|c|c|c|c|c|c|}
\hline $\begin{array}{l}\text { Descrip. } \\
\text { Page \# }\end{array}$ & Sample ID & $\begin{array}{l}\text { Wshed } \\
\text { Area }\end{array}$ & $\begin{array}{l}\text { Landscape } \\
\text { Position }\end{array}$ & $\mathrm{Ca}$ & $\mathrm{Mg}$ & K & $\mathrm{Na}$ \\
\hline & & & & \multicolumn{4}{|c|}{$\mathrm{mg} / \mathrm{kg}$} \\
\hline \multirow[t]{6}{*}{79} & FS04WV025010A/E & East & Shoulder & 235 & 67.4 & 152 & 23 \\
\hline & FS04WV025010BA & East & Shoulder & 37 & 16.2 & 62 & 10 \\
\hline & FS04WV025010Bt & East & Shoulder & 23 & 8.0 & 38 & 8 \\
\hline & FS04WV025010Btx1 & East & Shoulder & 34 & 9.5 & 36 & 4 \\
\hline & FS04WV025010Btx2 & East & Shoulder & 27 & 11.9 & 41 & 4 \\
\hline & FS04WV025010BC & East & Shoulder & 29 & 13.2 & 47 & 3 \\
\hline \multirow[t]{5}{*}{81} & FS04WV025019A & East & Floodplain & 102 & 35.3 & 100 & 20 \\
\hline & FS04WV025019Bw1 & East & Floodplain & 49 & 21.5 & 47 & 6 \\
\hline & FS04WV025019Bw2 & East & Floodplain & 52 & 22.5 & 48 & 4 \\
\hline & FS04WV025019Bw3 & East & Floodplain & 51 & 19.8 & 43 & 6 \\
\hline & FS04WV025019BC & East & Floodplain & 76 & 36.1 & 39 & 4 \\
\hline \multirow[t]{5}{*}{83} & FS04WV101001A & East & Ridge & 345 & 47.7 & 128 & 15 \\
\hline & FS04WV101001BA & East & Ridge & 97 & 19.4 & 55 & 15 \\
\hline & FS04WV101001Bt1 & East & Ridge & 28 & 7.7 & 37 & 14 \\
\hline & FS04WV101001Bt2 & East & Ridge & 16 & 3.9 & 31 & 8 \\
\hline & FS04WV101001Bt3 & East & Ridge & 13 & 2.5 & 33 & 7 \\
\hline \multirow[t]{6}{*}{84} & FS04WV067007A & East & Shoulder & 47 & 26.1 & 52 & 12 \\
\hline & FS04WV067007BA & East & Shoulder & 20 & 7.9 & 23 & 13 \\
\hline & FS04WV067007Bw1 & East & Shoulder & 17 & 4.7 & 14 & 9 \\
\hline & FS04WV067007Bw2 & East & Shoulder & 11 & 2.7 & 13 & 5 \\
\hline & FS04WV067007Bw3 & East & Shoulder & 8.5 & 2.5 & 17 & 4 \\
\hline & FS04WV067007BC & East & Shoulder & 8.0 & 3.0 & 26 & 4 \\
\hline \multirow[t]{7}{*}{85} & FS04WV067001A & West & Back slope & 301 & 44.2 & 62 & 14 \\
\hline & FS04WV067001AB & West & Back slope & 26 & 5.2 & 23 & 7 \\
\hline & FS04WV067001Bw1 & West & Back slope & 21 & 4.4 & 21 & 4 \\
\hline & FS04WV067001BW2 & West & Back slope & 19 & 4.2 & 23 & 5 \\
\hline & FS04WV067001Bw3 & West & Back slope & 16 & 3.7 & 24 & 3 \\
\hline & FS04WV067001BC & West & Back slope & 18 & 4.0 & 20 & 3 \\
\hline & FS04WV067001C & West & Back slope & 16 & 4.0 & 13 & 3 \\
\hline \multirow[t]{4}{*}{87} & FS04WV067002A & West & Ridge & 40 & 14.1 & 43 & 6 \\
\hline & FS04WV067002BA & West & Ridge & 19 & 4.2 & 14 & 5 \\
\hline & FS04WV067002Bw1 & West & Ridge & 46 & 6.3 & 14 & 6 \\
\hline & FS04WV067002Bw2 & West & Ridge & 17 & 3.8 & 17 & 5 \\
\hline \multirow[t]{4}{*}{88} & FS04WV067003A & West & Ridge & 370 & 26.6 & 93 & 12 \\
\hline & FS04WV067003AB & West & Ridge & 115 & 10.2 & 44 & 12 \\
\hline & FS04WV067003Bw1 & West & Ridge & 63 & 6.7 & 28 & 7 \\
\hline & FS04WV067003Bw2 & West & Ridge & 39 & 6.0 & 24 & 5 \\
\hline
\end{tabular}




\begin{tabular}{|c|c|c|c|c|c|c|c|}
\hline $\begin{array}{l}\text { Descrip. } \\
\text { Page \# }\end{array}$ & Sample ID & $\begin{array}{l}\text { Wshed } \\
\text { Area }\end{array}$ & $\begin{array}{l}\text { Landscape } \\
\text { Position }\end{array}$ & $\mathrm{Ca}$ & Mg & $\mathrm{K}$ & $\mathrm{Na}$ \\
\hline & & & & & & & \\
\hline & FS04WV067003BC & West & Ridge & 31 & 5.5 & 26 & 4 \\
\hline 89 & FS04WV067004A & West & Floodplain & 118 & 26.4 & 42 & 7 \\
\hline & FS04WV067004BA & West & Floodplain & 25 & 8.0 & 30 & 7 \\
\hline & FS04WV067004Bw1 & West & Floodplain & 13 & 4.6 & 23 & 3 \\
\hline & FS04WV067004Bw2 & West & Floodplain & 19 & 6.7 & 31 & 4 \\
\hline & FS04WV067004Ab & West & Floodplain & 41 & 10.6 & 28 & 7 \\
\hline & FS04WV067004C1 & West & Floodplain & 62 & 18.5 & 23 & 5 \\
\hline & FS04WV067004C2 & West & Floodplain & 30 & 10.9 & 14 & 3 \\
\hline & FS04WV067004C3 & West & Floodplain & 114 & 70.6 & 20 & 5 \\
\hline 91 & FS04WV067005A & West & Bench & 108 & 40.9 & 53 & 9 \\
\hline & FS04WV067005AB & West & Bench & 33 & 17.8 & 43 & 6 \\
\hline & FS04WV067005Bw1 & West & Bench & 12 & 6.8 & 35 & 4 \\
\hline & FS04WV067005Bw2 & West & Bench & 14 & 7.7 & 35 & 4 \\
\hline & FS04WV067005BW3 & West & Bench & 22 & 15.4 & 34 & 5 \\
\hline & FS04WV067005Bx1 & West & Bench & 30 & 25.4 & 35 & 4 \\
\hline & FS04WV067005Bx2 & West & Bench & 19 & 24.5 & 38 & 3 \\
\hline & FS04WV067005C & West & Bench & 33 & 26.2 & 37 & 6 \\
\hline 93 & FS04WV067006A & West & Foot & 212 & 37.5 & 84 & 13 \\
\hline & FS04WV067006AB & West & Foot & 72 & 12.9 & 57 & 11 \\
\hline & FS04WV067006BW1 & West & Foot & 32 & 5.3 & 45 & 7 \\
\hline & FS04WV067006Bw2 & West & Foot & 42 & 7.4 & 46 & 6 \\
\hline & FS04WV067006BW3 & West & Foot & 92 & 16.3 & 39 & 5 \\
\hline & FS04WV067006BC & West & Foot & 92 & 17.2 & 39 & 5 \\
\hline 95 & FS04WV067017A1 & West & Shoulder & 34 & 13.5 & 38 & 10 \\
\hline & FS04WV067017A2 & West & Shoulder & 22 & 8.9 & 31 & 7 \\
\hline & FS04WV067017BA & West & Shoulder & 18 & 5.7 & 24 & 5 \\
\hline & FS04WV067017Bw & West & Shoulder & 12 & 4.9 & 25 & 3 \\
\hline & FS04WV067017BC & West & Shoulder & 10 & 5.2 & 27 & 2 \\
\hline & FS04WV067017C & West & Shoulder & 8.1 & 3.3 & 24 & 2.0 \\
\hline 96 & FS04WV025006A & East & Back slope & 138 & 30.0 & 54 & 8 \\
\hline & FS04WV025006BA & East & Back slope & 39 & 13.1 & 34 & 7 \\
\hline & FS04WV025006Bt & East & Back slope & 24 & 6.6 & 23 & 10 \\
\hline 96 & FS04WV025007A & East & Bench & 179 & 37.8 & 101 & 12 \\
\hline & FS04WV025007BA & East & Bench & 27 & 9.7 & 29 & 6 \\
\hline & FS04WV025007Bw & East & Bench & 43 & 9.7 & 31 & 9 \\
\hline 97 & FS04WV025008A & East & Floodplain & 330 & 61.1 & 77 & 12 \\
\hline & FS04WV025008Bt & East & Floodplain & 49 & 14.9 & 43 & 6 \\
\hline
\end{tabular}




\begin{tabular}{|c|c|c|c|c|c|c|c|}
\hline $\begin{array}{l}\text { Descrip } \\
\text { Page \# }\end{array}$ & Sample ID & $\begin{array}{l}\text { Wshed } \\
\text { Area }\end{array}$ & $\begin{array}{l}\text { Landscape } \\
\text { Position }\end{array}$ & $\mathrm{Ca}$ & Mg & K & $\mathrm{Na}$ \\
\hline & & & & & & & \\
\hline 97 & FS04WV025009A & East & Foot & 98 & 34.2 & 88 & 11 \\
\hline & FS04WV025009Bt & East & Foot & 34 & 12.9 & 52 & 7 \\
\hline 98 & FS04WV025011A & East & Shoulder & 146 & 37.5 & 73 & 9 \\
\hline & FS04WV025011BA & East & Shoulder & 56 & 17.3 & 45 & 5 \\
\hline & FS04WV025011Bt & East & Shoulder & 41 & 11.9 & 33 & 6 \\
\hline 98 & FS04WV025012A & East & Bench & 39 & 25.2 & 73 & 5 \\
\hline & FS04WV025012BW & East & Bench & 19 & 6.4 & 28 & 7 \\
\hline 99 & FS04WV025013A & East & Ridge & 311 & 46.3 & 76 & 12 \\
\hline & FS04WV025013BA & East & Ridge & 34 & 12.4 & 33 & 4 \\
\hline & FS04WV025013Bt & East & Ridge & 16 & 8.4 & 34 & 8 \\
\hline 99 & FS04WV025014A & East & Back slope & 177 & 32.8 & 57 & 6 \\
\hline & FS04WV025014BA & East & Back slope & 38 & 14.4 & 44 & 4 \\
\hline & FS04WV025014Bt & East & Back slope & 47 & 14.8 & 40 & 6 \\
\hline 100 & FS04WV025015A & East & Shoulder & 100 & 44.5 & 68 & 8 \\
\hline & FS04WV025015Bt & East & Shoulder & 13 & 10.8 & 40 & 6 \\
\hline 100 & FS04WV067008A & West & Foot & 131 & 23.2 & 54 & 9 \\
\hline & FS04WV067008BA & West & Foot & 38 & 7.0 & 33 & 7 \\
\hline & FS04WV067008Bw & West & Foot & 30 & 5.1 & 31 & 8 \\
\hline 101 & FS04WV067009A & West & Floodplain & 81 & 23.3 & 49 & 11 \\
\hline & FS04WV067009BA & West & Floodplain & 18 & 5.3 & 16 & 3 \\
\hline & FS04WV067009Bg & West & Floodplain & 18 & 4.6 & 18 & 5 \\
\hline 101 & FS04WV067010A & West & Back slope & 130 & 28.4 & 68 & 9 \\
\hline & FS04WV067010BA & West & Back slope & 40 & 14.6 & 44 & 7 \\
\hline & FS04WV067010Bw & West & Back slope & 52 & 11.7 & 43 & 7 \\
\hline 102 & FS04WV067011BA & West & Floodplain & 43 & 5.6 & 21 & 5 \\
\hline & FS04WV067011Bw & West & Floodplain & 20 & 2.6 & 13 & 3 \\
\hline 102 & FS04WV067012A & West & Ridge & 141 & 32.6 & 112 & 14 \\
\hline & FS04WV067012BA & West & Ridge & 38 & 13.9 & 62 & 9 \\
\hline & FS04WV067012Bw & West & Ridge & 36 & 12.1 & 49 & 8 \\
\hline 103 & FS04WV067013A & West & Back slope & 139 & 31.4 & 96 & 17 \\
\hline & FS04WV067013BA & West & Back slope & 19 & 5.2 & 22 & 7 \\
\hline & FS04WV067013Bw & West & Back slope & 16 & 3.1 & 17 & 7 \\
\hline
\end{tabular}




\begin{tabular}{|c|c|c|c|c|c|c|c|}
\hline $\begin{array}{l}\text { Descrip. } \\
\text { Page \# }\end{array}$ & Sample ID & $\begin{array}{l}\text { Wshed } \\
\text { Area }\end{array}$ & $\begin{array}{l}\text { Landscape } \\
\text { Position }\end{array}$ & $\mathrm{Ca}$ & Mg & K & $\mathrm{Na}$ \\
\hline & & & & & $\mathrm{mg}$ & & \\
\hline 103 & FS04WV067014A & West & Bench & 321 & 34.0 & 108 & 12 \\
\hline & FS04WV067014BA & West & Bench & 51 & 9.1 & 56 & 6 \\
\hline & FS04WV067014Bw & West & Bench & 42 & 7.4 & 46 & 7 \\
\hline 104 & FS04WV067015A & West & Shoulder & 138 & 25.3 & 99 & 11 \\
\hline & FS04WV067015BA & West & Shoulder & 68 & 10.2 & 47 & 7 \\
\hline & FS04WV067015Bw & West & Shoulder & 40 & 5.0 & 35 & 6 \\
\hline 104 & FS04WV067016A & West & Ridge & 201 & 26.5 & 82 & 12 \\
\hline & FS04WV067016BA & West & Ridge & 35 & 6.7 & 30 & 8 \\
\hline & FS04WV067016Bt & West & Ridge & 21 & 4.5 & 27 & 5 \\
\hline 105 & FS04WV025016A1 & East & Floodplain & 196 & 37.8 & 53 & 9 \\
\hline & FS04WV025016A2 & East & Floodplain & 58 & 18.6 & 37 & 9 \\
\hline & FS04WV025016Bw & East & Floodplain & 12 & 6.2 & 24 & 6 \\
\hline 105 & FS04WV025017A & East & Back slope & 136 & 28.5 & 61 & 7 \\
\hline & FS04WV025017BA & East & Back slope & 23 & 11.3 & 52 & 8 \\
\hline & FS04WV025017Bt & East & Back slope & 24 & 8.6 & 53 & 10 \\
\hline 106 & FS04WV025018A & East & Foot & 80 & 28.8 & 71 & 14 \\
\hline & FS04WV025018Bw & East & Foot & 17 & 6.9 & 29 & 4 \\
\hline 106 & FS04WV067018A & West & Foot & 91 & 16.6 & 48 & 9 \\
\hline & FS04WV067018BA & West & Foot & 25 & 4.6 & 23 & 6 \\
\hline & FS04WV067018Bt & West & Foot & 18 & 2.0 & 17 & 5 \\
\hline 107 & FS04WV067019A & West & Bench & 116 & 22.4 & 75 & 10 \\
\hline & FS04WV067019BA & West & Bench & 31 & 7.4 & 34 & 7 \\
\hline & FS04WV067019Bw & West & Bench & 26 & 4.1 & 27 & 7 \\
\hline 107 & FS04WV067020A & West & Shoulder & 59 & 25.4 & 61 & 8 \\
\hline & FS04WV067020BA & West & Shoulder & 17 & 5.7 & 36 & 5 \\
\hline & FS04WV067020Bt & West & Shoulder & 19 & 4.9 & 29 & 6 \\
\hline 108 & FS04WV067021A & West & Ridge & 109 & 31.1 & 86 & 7 \\
\hline & FS04WV067021BA & West & Ridge & 42 & 6.3 & 67 & 5 \\
\hline & FS04WV067021Bw & West & Ridge & 18 & 2.9 & 38 & 4 \\
\hline 108 & FS04WV067022A1 & West & Shoulder & 70 & 18.1 & 29 & 6 \\
\hline & FS04WV067022A2 & West & Shoulder & 18 & 5.1 & 12 & 3 \\
\hline & FS04WV067022AB & West & Shoulder & 24 & 6.3 & 13 & 5 \\
\hline 109 & FS04WV067023A & West & Ridge & 101 & 33.3 & 92 & 14 \\
\hline
\end{tabular}




\begin{tabular}{|c|c|c|c|c|c|c|c|}
\hline $\begin{array}{l}\text { Descrip. } \\
\text { Page \# }\end{array}$ & Sample ID & $\begin{array}{l}\text { Wshed } \\
\text { Area }\end{array}$ & $\begin{array}{l}\text { Landscape } \\
\text { Position }\end{array}$ & $\mathrm{Ca}$ & Mg & K & $\mathrm{Na}$ \\
\hline & & & & & & & \\
\hline & FS04WV067023BA & West & Ridge & 24 & 9.9 & 41 & 7 \\
\hline & FS04WV067023Bw & West & Ridge & 19 & 6.7 & 37 & 6 \\
\hline 109 & FS04WV067024BA & West & Back slope & 64 & 17.4 & 78 & 11 \\
\hline & FS04WV067024Bt & West & Back slope & 26 & 8.8 & 54 & 10 \\
\hline 110 & FS04WV025020A & East & Bench & 145 & 20.0 & 37 & 4 \\
\hline & FS04WV025020BA & East & Bench & 45 & 6.3 & 27 & 4 \\
\hline & FS04WV025020Bt & East & Bench & 38 & 5.4 & 23 & 4 \\
\hline 110 & FS04WV025021A & East & Back slope & 220 & 33.7 & 85 & 8 \\
\hline & FS04WV025021BA & East & Back slope & 60 & 11.3 & 53 & 5 \\
\hline & FS04WV025021Bw & East & Back slope & 37 & 8.9 & 47 & 7 \\
\hline 111 & FS04WV101002A & East & Ridge & 173 & 29.3 & 79 & 9 \\
\hline & FS04WV101002BA & East & Ridge & 182 & 22.2 & 55 & 8 \\
\hline & FS04WV101002Bt & East & Ridge & 194 & 19.2 & 53 & 16 \\
\hline 111 & FS04WV067025A & West & Ridge & 26 & 13.3 & 43 & 12 \\
\hline & FS04WV067025BA & West & Ridge & 17 & 6.4 & 23 & 8 \\
\hline & FS04WV067025Bw & West & Ridge & 8.6 & 2.6 & 13 & 5 \\
\hline 112 & FS04WV067026A & West & Ridge & 107 & 34.8 & 72 & 15 \\
\hline & FS04WV067026BA & West & Ridge & 33 & 13.6 & 45 & 9 \\
\hline & FS04WV067026Bw & West & Ridge & 16 & 7.6 & 34 & 7 \\
\hline 112 & FS04WV067027A & West & Shoulder & 48 & 20.2 & 40 & 6 \\
\hline & FS04WV067027BA & West & Shoulder & 17 & 7.0 & 34 & 7 \\
\hline & FS04WV067027Bt & West & Shoulder & 23 & 4.2 & 30 & 8 \\
\hline 113 & FS04WV067028A1 & West & Back slope & 73 & 17.3 & 78 & 9 \\
\hline & FS04WV067028A2 & West & Back slope & 35 & 7.3 & 43 & 9 \\
\hline & FS04WV067028Bw & West & Back slope & 20 & 3.7 & 26 & 7 \\
\hline 113 & FS04WV067029A & West & Back slope & 60 & 14.3 & 51 & 11 \\
\hline & FS04WV067029BA & West & Back slope & 26 & 6.3 & 31 & 7 \\
\hline & FS04WV067029Bw & West & Back slope & 25 & 6.1 & 35 & 8 \\
\hline 114 & FS04WV067030A & West & Bench & 432 & 43.4 & 68 & 11 \\
\hline & FS04WV067030BA & West & Bench & 97 & 15.1 & 44 & 8 \\
\hline & FS04WV067030Bt & West & Bench & 55 & 7.9 & 37 & 9 \\
\hline 114 & FS04WV067031A & West & Bench & 89 & 24.3 & 90 & 10 \\
\hline & FS04WV067031BA & West & Bench & 25 & 9.6 & 46 & 6 \\
\hline
\end{tabular}




\begin{tabular}{|c|c|c|c|c|c|c|c|}
\hline $\begin{array}{l}\text { Descrip. } \\
\text { Page \# }\end{array}$ & Sample ID & $\begin{array}{l}\text { Wshed } \\
\text { Area }\end{array}$ & $\begin{array}{l}\text { Landscape } \\
\text { Position }\end{array}$ & $\mathrm{Ca}$ & Mg & $\mathrm{K}$ & $\mathrm{Na}$ \\
\hline & & & & & mg & & \\
\hline & FS04WV067031Bw & West & Bench & 16 & 5.7 & 38 & 5 \\
\hline 115 & FS04WV067032A & West & Foot & 162 & 35.2 & 29 & 8 \\
\hline & FS04WV067032Bt & West & Foot & 20 & 7.4 & 14 & 6 \\
\hline 115 & FS04WV025023A & East & Shoulder & 53 & 19.8 & 69 & 9 \\
\hline & FS04WV025023BA & East & Shoulder & 30 & 12.1 & 58 & 7 \\
\hline & FS04WV025023Bt & East & Shoulder & 28 & 9.4 & 50 & 8 \\
\hline 116 & FS04WV025024A & East & Back slope & 56 & 20.8 & 64 & 17 \\
\hline & FS04WV025024BA & East & Back slope & 20 & 4.4 & 27 & 7 \\
\hline & FS04WV025024Bw & East & Back slope & 25 & 5.0 & 25 & 10 \\
\hline 116 & FS04WV025025A & East & Bench & 64 & 22.2 & 68 & 18 \\
\hline & FS04WV025025BA & East & Bench & 28 & 10.3 & 43 & 8 \\
\hline & FS04WV025025Bt & East & Bench & 28 & 8.0 & 39 & 7 \\
\hline 117 & FS04WV067033A1 & East & Floodplain & 86 & 34.2 & 88 & 22 \\
\hline & FS04WV067033A2 & East & Floodplain & 40 & 21.5 & 51 & 11 \\
\hline & FS04WV067033BA & East & Floodplain & 35 & 17.0 & 50 & 13 \\
\hline 117 & FS04WV067034A & East & Back slope & 52 & 15.2 & 44 & 7 \\
\hline & FS04WV067034BA & East & Back slope & 22 & 9.5 & 39 & 7 \\
\hline & FS04WV067034Bt & East & Back slope & 14 & 3.8 & 30 & 8 \\
\hline 118 & FS04WV101003A & East & Back slope & 95 & 121 & 52 & 10 \\
\hline & FS04WV101003BA & East & Back slope & 33 & 44.2 & 37 & 7 \\
\hline & FS04WV101003Bt & East & Back slope & 24 & 15.8 & 28 & 8 \\
\hline 118 & FS04WV101004A & East & Ridge & 116 & 23.2 & 66 & 11 \\
\hline & FS04WV101004BA & East & Ridge & 28 & 9.4 & 44 & 8 \\
\hline & FS04WV101004Bt & East & Ridge & 26 & 6.1 & 37 & 13 \\
\hline 119 & FS04WV101005A1 & East & Bench & 40 & 6.3 & 21 & 5 \\
\hline & FS04WV101005A2 & East & Bench & 24 & 5.6 & 21 & 8 \\
\hline & FS04WV101005Ab & East & Bench & 44 & 8.1 & 24 & 9 \\
\hline 119 & FS04WV101006A & East & Bench & 97 & 19.5 & 67 & 8 \\
\hline & FS04WV101006BA & East & Bench & 51 & 13.5 & 55 & 10 \\
\hline & FS04WV101006Bt & East & Bench & 59 & 10.6 & 53 & 17 \\
\hline 120 & FS04WV025026A & East & Foot & 91 & 29.3 & 51 & 9 \\
\hline & FS04WV025026BA & East & Foot & 20 & 8.1 & 36 & 7 \\
\hline
\end{tabular}




\begin{tabular}{llllcccc}
\hline $\begin{array}{l}\text { Descrip. Sample ID } \\
\text { Page \# }\end{array}$ & $\begin{array}{l}\text { Wshed } \\
\text { Area }\end{array}$ & $\begin{array}{l}\text { Landscape } \\
\text { Position }\end{array}$ & Ca & Mg & K & Na \\
\hline & & & \multicolumn{5}{c}{ mg/kg } \\
\hline & FS04WV025026Bt & East & Foot & 21 & 7.3 & 34 & 9 \\
\hline 120 & & & & & & \\
\hline & FS04WV025027A & East & Foot & 98 & 22.5 & 69 & 12 \\
\hline & FS04WV025027BA & East & Foot & 30 & 8.0 & 42 & 8 \\
\hline & FS04WV025027Bt & East & Foot & 27 & 5.5 & 39 & 11 \\
\hline 121 & & & & & & \\
\hline & FS04WV025022A & East & Ridge & 334 & 43.9 & 113 & 14 \\
\hline & FS04WV025022Bt & East & Ridge & 55 & 9.9 & 47 & 13 \\
\hline
\end{tabular}




\section{APPENDIX G ACID CATION DATA}

\begin{tabular}{|c|c|c|c|c|c|c|}
\hline \multirow[t]{2}{*}{$\begin{array}{l}\text { Descrip. } \\
\text { Page \# }\end{array}$} & \multirow[t]{2}{*}{ Sample ID } & \multirow[t]{2}{*}{$\begin{array}{l}\text { Wshed } \\
\text { Area }\end{array}$} & \multirow[t]{2}{*}{$\begin{array}{l}\text { Landscape } \\
\text { Position }\end{array}$} & Al & $\mathrm{Fe}$ & Mn \\
\hline & & & & \multicolumn{3}{|c|}{$\mathrm{mg} / \mathrm{kg}$} \\
\hline \multirow[t]{8}{*}{69} & FS04WV025001A1 & East & Back slope & 634 & 128 & 65.7 \\
\hline & FS04WV025001A2 & East & Back slope & 601 & 86 & 16.3 \\
\hline & FS04WV025001AB & East & Back slope & 946 & 70 & 8.7 \\
\hline & FS04WV025001Bw1 & East & Back slope & 380 & 9.0 & 1.5 \\
\hline & FS04WV025001Bw2 & East & Back slope & 286 & 7.3 & 1.4 \\
\hline & FS04WV025001Bw3 & East & Back slope & 253 & 12 & 1.5 \\
\hline & FS04WV025001Bw4 & East & Back slope & 178 & 3.7 & 1.0 \\
\hline & FS04WV025001BC & East & Back slope & 155 & 4.0 & 1.6 \\
\hline \multirow[t]{7}{*}{71} & FS04WV025002A & East & Back slope & 745 & 14 & 119 \\
\hline & FS04WV025002AB & East & Back slope & 573 & 2.8 & 22.0 \\
\hline & FS04WV025002Bw1 & East & Back slope & 432 & 5.2 & 12.1 \\
\hline & FS04WV025002Bw2 & East & Back slope & 418 & 4.8 & 11.3 \\
\hline & FS04WV025002Bw3 & East & Back slope & 442 & 2.1 & 9.8 \\
\hline & FS04WV025002BC1 & East & Back slope & 370 & 2.3 & 12.8 \\
\hline & FS04WV025002BC2 & East & Back slope & 405 & 1.1 & 7.8 \\
\hline \multirow[t]{5}{*}{73} & FS04WV025003A & East & Ridge & 1006 & 93 & 16.2 \\
\hline & FS04WV025003Bw1 & East & Ridge & 686 & 16 & 15.5 \\
\hline & FS04WV025003Bw2 & East & Ridge & 459 & 3.0 & 5.1 \\
\hline & FS04WV025003Bx1 & East & Ridge & 363 & 3.3 & 4.3 \\
\hline & FS04WV025003Bx2 & East & Ridge & 475 & 0.9 & 2.2 \\
\hline \multirow[t]{8}{*}{75} & FS04WV025004A & East & Foot & 422 & 52 & 37.7 \\
\hline & FS04WV025004AB & East & Foot & 723 & 62 & 9.5 \\
\hline & FS04WV025004Bw1 & East & Foot & 433 & 22 & 3.6 \\
\hline & FS04WV025004Bw2 & East & Foot & 210 & 6.6 & 1.6 \\
\hline & FS04WV025004Bw3 & East & Foot & 257 & 2.0 & 1.9 \\
\hline & FS04WV025004Bw4 & East & Foot & 274 & 1.7 & 3.8 \\
\hline & FS04WV025004Bx & East & Foot & 295 & 1.0 & 3.8 \\
\hline & FS04WV025004BC & East & Foot & 256 & 1.1 & 6.7 \\
\hline \multirow[t]{6}{*}{77} & FS04WV025005A & East & Bench & 855 & 101 & 20.1 \\
\hline & FS04WV025005AB & East & Bench & 1005 & 90 & 8.0 \\
\hline & FS04WV025005Bw1 & East & Bench & 481 & 4.1 & 16.3 \\
\hline & FS04WV025005Bw2 & East & Bench & 393 & 3.3 & 5.2 \\
\hline & FS04WV025005Bx1 & East & Bench & 364 & 2.7 & 6.4 \\
\hline & FS04WV025005Bx2 & East & Bench & 295 & 3.8 & 6.6 \\
\hline
\end{tabular}




\begin{tabular}{|c|c|c|c|c|c|c|}
\hline \multirow[t]{3}{*}{$\begin{array}{l}\text { Descrip. } \\
\text { Page \# }\end{array}$} & \multirow{3}{*}{$\begin{array}{l}\text { Sample ID } \\
\text { FS04WV025005B X3 }\end{array}$} & \multirow{3}{*}{$\begin{array}{l}\begin{array}{l}\text { Wshed } \\
\text { Area }\end{array} \\
\text { East } \\
\end{array}$} & \multirow{3}{*}{$\begin{array}{l}\text { Landscape } \\
\text { Position } \\
\text { Bench } \\
\end{array}$} & \multirow{2}{*}{\multicolumn{2}{|c|}{$\begin{array}{c}\mathrm{Fe} \\
\mathrm{mg} / \mathrm{kg}\end{array}$}} & \multirow[t]{2}{*}{ Mn } \\
\hline & & & & & & \\
\hline & & & & 520 & 1.4 & 12.0 \\
\hline & FS04WV025005BC & East & Bench & 559 & 1.6 & 15.1 \\
\hline \multirow[t]{6}{*}{79} & FS04WV025010A/E & East & Shoulder & 747 & 98 & 65.2 \\
\hline & FS04WV025010BA & East & Shoulder & 614 & 16 & 14.9 \\
\hline & FS04WV025010Bt & East & Shoulder & 436 & 15 & 3.6 \\
\hline & FS04WV025010Btx1 & East & Shoulder & 363 & 0.8 & 10.8 \\
\hline & FS04WV025010Btx2 & East & Shoulder & 382 & 1.6 & 14.0 \\
\hline & FS04WV025010BC & East & Shoulder & 372 & 3.1 & 23.2 \\
\hline \multirow[t]{5}{*}{81} & FS04WV025019A & East & Floodplain & 530 & 8.6 & 82.8 \\
\hline & FS04WV025019Bw1 & East & Floodplain & 345 & 3.1 & 39.4 \\
\hline & FS04WV025019Bw2 & East & Floodplain & 350 & 2.2 & 53.5 \\
\hline & FS04WV025019Bw3 & East & Floodplain & 244 & 2.5 & 39.2 \\
\hline & FS04WV025019BC & East & Floodplain & 178 & 0.3 & 40.2 \\
\hline \multirow[t]{5}{*}{83} & FS04WV101001A & East & Ridge & 502 & 44 & 30.3 \\
\hline & FS04WV101001BA & East & Ridge & 976 & 74 & 5.9 \\
\hline & FS04WV101001Bt1 & East & Ridge & 694 & 23 & 8.6 \\
\hline & FS04WV101001Bt2 & East & Ridge & 511 & 9.3 & 2.5 \\
\hline & FS04WV101001Bt3 & East & Ridge & 435 & 5.4 & 3.5 \\
\hline \multirow[t]{6}{*}{84} & FS04WV067007A & East & Shoulder & 827 & 109 & 3.8 \\
\hline & FS04WV067007BA & East & Shoulder & 429 & 18 & 0.7 \\
\hline & FS04WV067007Bw1 & East & Shoulder & 234 & 7.4 & 0.6 \\
\hline & FS04WV067007Bw2 & East & Shoulder & 240 & 5.0 & 0.6 \\
\hline & FS04WV067007Bw3 & East & Shoulder & 262 & 5.4 & 0.8 \\
\hline & FS04WV067007BC & East & Shoulder & 304 & 3.9 & 8.6 \\
\hline \multirow[t]{7}{*}{85} & FS04WV067001A & West & Back slope & 399 & 16 & 51.7 \\
\hline & FS04WV067001AB & West & Back slope & 248 & 3.5 & 1.1 \\
\hline & FS04WV067001Bw1 & West & Back slope & 202 & 5.4 & 0.6 \\
\hline & FS04WV067001Bw2 & West & Back slope & 254 & 6.7 & 0.5 \\
\hline & FS04WV067001Bw3 & West & Back slope & 253 & 6.2 & 0.25 \\
\hline & FS04WV067001BC & West & Back slope & 177 & 3.0 & 0.25 \\
\hline & FS04WV067001C & West & Back slope & 114 & 1.6 & 0.25 \\
\hline \multirow[t]{4}{*}{87} & FS04WV067002A & West & Ridge & 434 & 6.5 & 35.2 \\
\hline & FS04WV067002BA & West & Ridge & 238 & 5.1 & 2.6 \\
\hline & FS04WV067002Bw1 & West & Ridge & 214 & 3.9 & 2.9 \\
\hline & FS04WV067002Bw2 & West & Ridge & 210 & 7.6 & 1.4 \\
\hline
\end{tabular}




\begin{tabular}{|c|c|c|c|c|c|c|}
\hline \multirow[t]{2}{*}{$\begin{array}{l}\text { Descrip. } \\
\text { Page \# }\end{array}$} & \multirow[t]{2}{*}{ Sample ID } & \multirow[t]{2}{*}{$\begin{array}{l}\text { Wshed } \\
\text { Area }\end{array}$} & \multirow[t]{2}{*}{$\begin{array}{l}\text { Landscape } \\
\text { Position }\end{array}$} & $\mathrm{Al}$ & $\mathrm{Fe}$ & Mn \\
\hline & & & & \multicolumn{3}{|c|}{$\mathrm{mg} / \mathrm{kg}$} \\
\hline \multirow[t]{5}{*}{88} & FS04WV067003A & West & Ridge & 512 & 8.4 & 187 \\
\hline & FS04WV067003AB & West & Ridge & 408 & 5.4 & 42.8 \\
\hline & FS04WV067003Bw1 & West & Ridge & 378 & 6.5 & 7.1 \\
\hline & FS04WV067003Bw2 & West & Ridge & 277 & 6.8 & 1.7 \\
\hline & FS04WV067003BC & West & Ridge & 278 & 3.5 & 3.5 \\
\hline \multirow[t]{8}{*}{89} & FS04WV067004A & West & Floodplain & 346 & 16 & 39.4 \\
\hline & FS04WV067004BA & West & Floodplain & 307 & 6.3 & 11.3 \\
\hline & FS04WV067004BW1 & West & Floodplain & 219 & 4.6 & 1.2 \\
\hline & FS04WV067004Bw2 & West & Floodplain & 249 & 3.9 & 7.1 \\
\hline & FS04WV067004Ab & West & Floodplain & 217 & 2.8 & 41.6 \\
\hline & FS04WV067004C1 & West & Floodplain & 99 & 3.8 & 34.2 \\
\hline & FS04WV067004C2 & West & Floodplain & 56 & 2.5 & 10.2 \\
\hline & FS04WV067004C3 & West & Floodplain & 27 & 4.2 & 3.4 \\
\hline \multirow[t]{8}{*}{91} & FS04WV067005A & West & Bench & 599 & 22 & 43.5 \\
\hline & FS04WV067005AB & West & Bench & 442 & 10 & 23.9 \\
\hline & FS04WV067005Bw1 & West & Bench & 327 & 5.4 & 6.1 \\
\hline & FS04WV067005Bw2 & West & Bench & 301 & 4.3 & 3.2 \\
\hline & FS04WV067005BW3 & West & Bench & 250 & 2.8 & 3.3 \\
\hline & FS04WV067005Bx1 & West & Bench & 257 & 1.2 & 3.2 \\
\hline & FS04WV067005Bx2 & West & Bench & 298 & 0.7 & 3.5 \\
\hline & FS04WV067005C & West & Bench & 244 & 1.7 & 17.7 \\
\hline \multirow[t]{6}{*}{93} & FS04WV067006A & West & Foot & 592 & 5.6 & 102 \\
\hline & FS04WV067006AB & West & Foot & 505 & 2.2 & 42.1 \\
\hline & FS04WV067006Bw1 & West & Foot & 345 & 1.3 & 13.7 \\
\hline & FS04WV067006Bw2 & West & Foot & 336 & 0.8 & 20.6 \\
\hline & FS04WV067006Bw3 & West & Foot & 281 & 2.7 & 9.4 \\
\hline & FS04WV067006BC & West & Foot & 283 & 1.8 & 7.3 \\
\hline \multirow[t]{6}{*}{95} & FS04WV067017A1 & West & Shoulder & 520 & 36 & 10.0 \\
\hline & FS04WV067017A2 & West & Shoulder & 312 & 8.5 & 4.5 \\
\hline & FS04WV067017BA & West & Shoulder & 260 & 5.7 & 2.0 \\
\hline & FS04WV067017Bw & West & Shoulder & 259 & 5.3 & 1.0 \\
\hline & FS04WV067017BC & West & Shoulder & 292 & 7.1 & 0.6 \\
\hline & FS04WV067017C & West & Shoulder & 254 & 7.2 & 0.8 \\
\hline \multirow[t]{3}{*}{96} & FS04WV025006A & East & Back slope & 488 & 61 & 13.4 \\
\hline & FS04WV025006BA & East & Back slope & 778 & 67 & 4.2 \\
\hline & FS04WV025006Bt & East & Back slope & 508 & 15 & 2.6 \\
\hline
\end{tabular}




\begin{tabular}{|c|c|c|c|c|c|c|}
\hline \multirow[t]{2}{*}{$\begin{array}{l}\text { Descrip. } \\
\text { Page \# }\end{array}$} & \multirow[t]{2}{*}{ Sample ID } & \multirow[t]{2}{*}{$\begin{array}{l}\text { Wshed } \\
\text { Area }\end{array}$} & \multirow[t]{2}{*}{$\begin{array}{l}\text { Landscape } \\
\text { Position }\end{array}$} & Al & $\mathrm{Fe}$ & $\mathrm{Mn}$ \\
\hline & & & & \multicolumn{3}{|c|}{$\mathrm{mg} / \mathrm{kg}$} \\
\hline \multirow[t]{3}{*}{96} & FS04WV025007A & East & Bench & 542 & 22 & 112 \\
\hline & FS04WV025007BA & East & Bench & 275 & 3.3 & 18.5 \\
\hline & FS04WV025007Bw & East & Bench & 306 & 5.3 & 10.5 \\
\hline \multirow[t]{2}{*}{97} & FS04WV025008A & East & Floodplain & 1101 & 143 & 23.2 \\
\hline & FS04WV025008Bt & East & Floodplain & 694 & 20 & 7.3 \\
\hline \multirow[t]{2}{*}{97} & FS04WV025009A & East & Foot & 631 & 3.1 & 182 \\
\hline & FS04WV025009Bt & East & Foot & 499 & 1.6 & 41.9 \\
\hline \multirow[t]{3}{*}{98} & FS04WV025011A & East & Shoulder & 633 & 22 & 78.6 \\
\hline & FS04WV025011BA & East & Shoulder & 503 & 11 & 25.4 \\
\hline & FS04WV025011Bt & East & Shoulder & 419 & 5.2 & 12.1 \\
\hline \multirow[t]{2}{*}{98} & FS04WV025012A & East & Bench & 610 & 17 & 71.3 \\
\hline & FS04WV025012BW & East & Bench & 301 & 3.3 & 12.2 \\
\hline \multirow[t]{3}{*}{99} & FS04WV025013A & East & Ridge & 271 & 28 & 69.4 \\
\hline & FS04WV025013BA & East & Ridge & 619 & 37 & 12.2 \\
\hline & FS04WV025013Bt & East & Ridge & 779 & 23 & 17.0 \\
\hline \multirow[t]{3}{*}{99} & FS04WV025014A & East & Back slope & 578 & 23 & 43.2 \\
\hline & FS04WV025014BA & East & Back slope & 555 & 7.8 & 19.3 \\
\hline & FS04WV025014Bt & East & Back slope & 480 & 2.3 & 15.9 \\
\hline \multirow[t]{2}{*}{100} & FS04WV025015A & East & Shoulder & 715 & 51 & 15.3 \\
\hline & FS04WV025015Bt & East & Shoulder & 794 & 41 & 3.5 \\
\hline \multirow[t]{3}{*}{100} & FS04WV067008A & West & Foot & 495 & 24 & 50.8 \\
\hline & FS04WV067008BA & West & Foot & 445 & 15 & 8.1 \\
\hline & FS04WV067008Bw & West & Foot & 438 & 5.9 & 3.5 \\
\hline \multirow[t]{3}{*}{101} & FS04WV067009A & West & Floodplain & 279 & 19 & 47.3 \\
\hline & FS04WV067009BA & West & Floodplain & 123 & 3.1 & 23.7 \\
\hline & FS04WV067009Bg & West & Floodplain & 128 & 2.9 & 22.9 \\
\hline \multirow[t]{3}{*}{101} & FS04WV067010A & West & Back slope & 351 & 2.9 & 98.5 \\
\hline & FS04WV067010BA & West & Back slope & 218 & 0.9 & 37.9 \\
\hline & FS04WV067010Bw & West & Back slope & 224 & 1.1 & 26.6 \\
\hline \multirow[t]{2}{*}{102} & FS04WV067011BA & West & Floodplain & 178 & 1.8 & 10.9 \\
\hline & FS04WV067011Bw & West & Floodplain & 115 & 2.0 & 5.8 \\
\hline
\end{tabular}




\begin{tabular}{|c|c|c|c|c|c|c|}
\hline \multirow[t]{2}{*}{$\begin{array}{l}\text { Descrip. } \\
\text { Page \# }\end{array}$} & \multirow[t]{2}{*}{ Sample ID } & \multirow[t]{2}{*}{$\begin{array}{l}\text { Wshed } \\
\text { Area }\end{array}$} & \multirow[t]{2}{*}{$\begin{array}{l}\text { Landscape } \\
\text { Position }\end{array}$} & Al & $\mathrm{Fe}$ & Mn \\
\hline & & & & \multicolumn{3}{|c|}{$\mathrm{mg} / \mathrm{kg}$} \\
\hline \multirow[t]{3}{*}{102} & FS04WV067012A & West & Ridge & 671 & 10 & 157 \\
\hline & FS04WV067012BA & West & Ridge & 500 & 2.6 & 37.1 \\
\hline & FS04WV067012Bw & West & Ridge & 496 & 3.2 & 15.9 \\
\hline \multirow[t]{3}{*}{103} & FS04WV067013A & West & Back slope & 513 & 30 & 107 \\
\hline & FS04WV067013BA & West & Back slope & 221 & 3.1 & 8.7 \\
\hline & FS04WV067013Bw & West & Back slope & 163 & 2.3 & 5.3 \\
\hline \multirow[t]{3}{*}{103} & FS04WV067014A & West & Bench & 306 & 1.9 & 223 \\
\hline & FS04WV067014BA & West & Bench & 256 & 1.0 & 42.6 \\
\hline & FS04WV067014Bw & West & Bench & 326 & 1.0 & 24.0 \\
\hline \multirow[t]{3}{*}{104} & FS04WV067015A & West & Shoulder & 390 & 2.4 & 163 \\
\hline & FS04WV067015BA & West & Shoulder & 354 & 1.6 & 75.3 \\
\hline & FS04WV067015Bw & West & Shoulder & 283 & 1.2 & 25.5 \\
\hline \multirow[t]{3}{*}{104} & FS04WV067016A & West & Ridge & 373 & 4.3 & 118 \\
\hline & FS04WV067016BA & West & Ridge & 211 & 1.7 & 19.6 \\
\hline & FS04WV067016Bt & West & Ridge & 262 & 1.9 & 6.2 \\
\hline \multirow[t]{3}{*}{105} & FS04WV025016A1 & East & Floodplain & 737 & 79 & 29.7 \\
\hline & FS04WV025016A2 & East & Floodplain & 1142 & 92 & 5.8 \\
\hline & FS04WV025016Bw & East & Floodplain & 640 & 39 & 2.1 \\
\hline \multirow[t]{3}{*}{105} & FS04WV025017A & East & Back slope & 644 & 67 & 30.2 \\
\hline & FS04WV025017BA & East & Back slope & 927 & 47 & 12.9 \\
\hline & FS04WV025017Bt & East & Back slope & 816 & 13 & 8.2 \\
\hline \multirow[t]{2}{*}{106} & FS04WV025018A & East & Foot & 898 & 40 & 34.2 \\
\hline & FS04WV025018Bw & East & Foot & 577 & 16 & 4.7 \\
\hline \multirow[t]{3}{*}{106} & FS04WV067018A & West & Foot & 318 & 8.1 & 33.2 \\
\hline & FS04WV067018BA & West & Foot & 266 & 5.3 & 3.5 \\
\hline & FS04WV067018Bt & West & Foot & 222 & 3.3 & 1.0 \\
\hline \multirow[t]{3}{*}{107} & FS04WV067019A & West & Bench & 478 & 9.5 & 34.5 \\
\hline & FS04WV067019BA & West & Bench & 361 & 3.1 & 7.5 \\
\hline & FS04WV067019Bw & West & Bench & 278 & 2.7 & 1.8 \\
\hline \multirow[t]{3}{*}{107} & FS04WV067020A & West & Shoulder & 440 & 50 & 7.3 \\
\hline & FS04WV067020BA & West & Shoulder & 307 & 14 & 3.6 \\
\hline & FS04WV067020Bt & West & Shoulder & 191 & 3.7 & 2.1 \\
\hline
\end{tabular}




\begin{tabular}{|c|c|c|c|c|c|c|}
\hline \multirow[t]{2}{*}{$\begin{array}{l}\text { Descrip. } \\
\text { Page \# }\end{array}$} & \multirow[t]{2}{*}{ Sample ID } & \multirow[t]{2}{*}{$\begin{array}{l}\text { Wshed } \\
\text { Area }\end{array}$} & \multirow[t]{2}{*}{$\begin{array}{l}\text { Landscape } \\
\text { Position }\end{array}$} & Al & $\mathrm{Fe}$ & Mn \\
\hline & & & & \multicolumn{3}{|c|}{$\mathrm{mg} / \mathrm{kg}$} \\
\hline \multirow[t]{3}{*}{108} & FS04WV067021A & West & Ridge & 482 & 16 & 62.4 \\
\hline & FS04WV067021BA & West & Ridge & 273 & 4.4 & 6.2 \\
\hline & FS04WV067021Bw & West & Ridge & 233 & 2.8 & 1.8 \\
\hline \multirow[t]{3}{*}{108} & FS04WV067022A1 & West & Shoulder & 152 & 14 & 13.5 \\
\hline & FS04WV067022A2 & West & Shoulder & 129 & 8.8 & 1.6 \\
\hline & FS04WV067022AB & West & Shoulder & 225 & 15 & 2.8 \\
\hline \multirow[t]{3}{*}{109} & FS04WV067023A & West & Ridge & 624 & 27 & 47.0 \\
\hline & FS04WV067023BA & West & Ridge & 431 & 4.8 & 11.6 \\
\hline & FS04WV067023Bw & West & Ridge & 415 & 6.8 & 3.2 \\
\hline \multirow[t]{2}{*}{109} & FS04WV067024BA & West & Back slope & 503 & 17 & 13.3 \\
\hline & FS04WV067024Bt & West & Back slope & 383 & 8.9 & 6.9 \\
\hline \multirow[t]{3}{*}{110} & FS04WV025020A & East & Bench & 264 & 1.7 & 38.4 \\
\hline & FS04WV025020BA & East & Bench & 228 & 1.0 & 21.0 \\
\hline & FS04WV025020Bt & East & Bench & 266 & 2.6 & 2.4 \\
\hline \multirow[t]{3}{*}{110} & FS04WV025021A & East & Back slope & 511 & 28 & 93.6 \\
\hline & FS04WV025021BA & East & Back slope & 638 & 6.2 & 38.5 \\
\hline & FS04WV025021BW & East & Back slope & 625 & 1.7 & 18.6 \\
\hline \multirow[t]{3}{*}{111} & FS04WV101002A & East & Ridge & 573 & 5.5 & 74.4 \\
\hline & FS04WV101002BA & East & Ridge & 432 & 4.5 & 15.5 \\
\hline & FS04WV101002Bt & East & Ridge & 482 & 8.7 & 10.4 \\
\hline \multirow[t]{3}{*}{111} & FS04WV067025A & West & Ridge & 469 & 23 & 3.2 \\
\hline & FS04WV067025BA & West & Ridge & 286 & 5.9 & 1.0 \\
\hline & FS04WV067025Bw & West & Ridge & 257 & 4.1 & 0.25 \\
\hline \multirow[t]{3}{*}{112} & FS04WV067026A & West & Ridge & 740 & 92 & 7.1 \\
\hline & FS04WV067026BA & West & Ridge & 708 & 38 & 5.8 \\
\hline & FS04WV067026Bw & West & Ridge & 343 & 12 & 1.8 \\
\hline \multirow[t]{3}{*}{112} & FS04WV067027A & West & Shoulder & 524 & 39 & 6.2 \\
\hline & FS04WV067027BA & West & Shoulder & 368 & 13 & 3.3 \\
\hline & FS04WV067027Bt & West & Shoulder & 245 & 2.7 & 3.5 \\
\hline \multirow[t]{3}{*}{113} & FS04WV067028A1 & West & Back slope & 564 & 3.7 & 107 \\
\hline & FS04WV067028A2 & West & Back slope & 356 & 1.5 & 29.9 \\
\hline & FS04WV067028Bw & West & Back slope & 269 & 3.1 & 10.9 \\
\hline
\end{tabular}




\begin{tabular}{|c|c|c|c|c|c|c|}
\hline \multirow[t]{2}{*}{$\begin{array}{l}\text { Descrip. } \\
\text { Page \# }\end{array}$} & \multirow[t]{2}{*}{ Sample ID } & \multirow[t]{2}{*}{$\begin{array}{l}\text { Wshed } \\
\text { Area }\end{array}$} & \multirow[t]{2}{*}{$\begin{array}{l}\text { Landscape } \\
\text { Position }\end{array}$} & Al & $\mathrm{Fe}$ & Mn \\
\hline & & & & \multicolumn{3}{|c|}{$\mathrm{mg} / \mathrm{kg}$} \\
\hline \multirow[t]{3}{*}{113} & FS04WV067029A & West & Back slope & 524 & 20 & 18.4 \\
\hline & FS04WV067029BA & West & Back slope & 303 & 3.4 & 12.5 \\
\hline & FS04WV067029Bw & West & Back slope & 280 & 3.9 & 5.7 \\
\hline \multirow[t]{3}{*}{114} & FS04WV067030A & West & Bench & 268 & 2.5 & 66.7 \\
\hline & FS04WV067030BA & West & Bench & 331 & 2.5 & 17.6 \\
\hline & FS04WV067030Bt & West & Bench & 321 & 3.2 & 6.1 \\
\hline \multirow[t]{3}{*}{114} & FS04WV067031A & West & Bench & 422 & 9.0 & 54.0 \\
\hline & FS04WV067031BA & West & Bench & 351 & 3.4 & 24.9 \\
\hline & FS04WV067031Bw & West & Bench & 289 & 2.2 & 4.5 \\
\hline \multirow[t]{2}{*}{115} & FS04WV067032A & West & Foot & 557 & 17 & 50.6 \\
\hline & FS04WV067032Bt & West & Foot & 224 & 3.8 & 13.7 \\
\hline \multirow[t]{3}{*}{115} & FS04WV025023A & East & Shoulder & 679 & 24 & 22.4 \\
\hline & FS04WV025023BA & East & Shoulder & 590 & 16 & 6.1 \\
\hline & FS04WV025023Bt & East & Shoulder & 538 & 9.2 & 4.2 \\
\hline \multirow[t]{3}{*}{116} & FS04WV025024A & East & Back slope & 822 & 36 & 21.3 \\
\hline & FS04WV025024BA & East & Back slope & 448 & 12 & 2.7 \\
\hline & FS04WV025024Bw & East & Back slope & 444 & 12 & 2.7 \\
\hline \multirow[t]{3}{*}{116} & FS04WV025025A & East & Bench & 915 & 38 & 8.5 \\
\hline & FS04WV025025BA & East & Bench & 711 & 32 & 4.0 \\
\hline & FS04WV025025Bt & East & Bench & 665 & 26 & 3.9 \\
\hline \multirow[t]{3}{*}{117} & FS04WV067033A1 & East & Floodplain & 822 & 83 & 17.9 \\
\hline & FS04WV067033A2 & East & Floodplain & 658 & 44 & 14.1 \\
\hline & FS04WV067033BA & East & Floodplain & 615 & 30 & 10.6 \\
\hline \multirow[t]{3}{*}{117} & FS04WV067034A & East & Back slope & 645 & 48 & 4.0 \\
\hline & FS04WV067034BA & East & Back slope & 526 & 35 & 1.8 \\
\hline & FS04WV067034Bt & East & Back slope & 264 & 10 & 1.0 \\
\hline \multirow[t]{3}{*}{118} & FS04WV101003A & East & Back slope & 565 & 19 & 29.0 \\
\hline & FS04WV101003BA & East & Back slope & 448 & 5.3 & 17.2 \\
\hline & FS04WV101003Bt & East & Back slope & 338 & 3.5 & 8.0 \\
\hline \multirow[t]{3}{*}{118} & FS04WV101004A & East & Ridge & 665 & 63 & 18.3 \\
\hline & FS04WV101004BA & East & Ridge & 605 & 21 & 10.1 \\
\hline & FS04WV101004Bt & East & Ridge & 535 & 12 & 4.8 \\
\hline
\end{tabular}




\begin{tabular}{|c|c|c|c|c|c|c|}
\hline \multirow[t]{2}{*}{$\begin{array}{l}\text { Descrip. } \\
\text { Page \# }\end{array}$} & \multirow[t]{2}{*}{ Sample ID } & \multirow[t]{2}{*}{$\begin{array}{l}\text { Wshed } \\
\text { Area }\end{array}$} & \multirow[t]{2}{*}{$\begin{array}{l}\text { Landscape } \\
\text { Position }\end{array}$} & Al & $\mathrm{Fe}$ & Mn \\
\hline & & & & \multicolumn{3}{|c|}{$\mathrm{mg} / \mathrm{kg}$} \\
\hline \multirow[t]{3}{*}{119} & FS04WV101005A1 & East & Bench & 187 & 17 & 6.6 \\
\hline & FS04WV101005A2 & East & Bench & 374 & 21 & 5.6 \\
\hline & FS04WV101005Ab & East & Bench & 431 & 21 & 2.1 \\
\hline \multirow[t]{3}{*}{119} & FS04WV101006A & East & Bench & 672 & 18 & 28.3 \\
\hline & FS04WV101006BA & East & Bench & 696 & 14 & 11.7 \\
\hline & FS04WV101006Bt & East & Bench & 598 & 14 & 5.8 \\
\hline \multirow[t]{3}{*}{120} & FS04WV025026A & East & Foot & 465 & 57 & 7.8 \\
\hline & FS04WV025026BA & East & Foot & 761 & 51 & 3.9 \\
\hline & FS04WV025026Bt & East & Foot & 626 & 25 & 6.0 \\
\hline \multirow[t]{3}{*}{120} & FS04WV025027A & East & Foot & 649 & 99 & 12.9 \\
\hline & FS04WV025027BA & East & Foot & 559 & 21 & 4.4 \\
\hline & FS04WV025027Bt & East & Foot & 557 & 16 & 2.8 \\
\hline \multirow[t]{2}{*}{121} & FS04WV025022A & East & Ridge & 390 & 41 & 102 \\
\hline & FS04WV025022Bt & East & Ridge & 353 & 10 & 12.6 \\
\hline
\end{tabular}




\section{APPENDIX H \\ CARBON AND NITROGEN DATA}

\begin{tabular}{|c|c|c|c|c|c|c|}
\hline $\begin{array}{l}\text { Descrip. } \\
\text { Page \# }\end{array}$ & Sample ID & $\begin{array}{l}\text { Wshed } \\
\text { Area }\end{array}$ & $\begin{array}{l}\text { Landscape } \\
\text { Position }\end{array}$ & $\begin{array}{c}\text { LOI } \\
\%\end{array}$ & $\begin{array}{l}\text { TN } \\
\%\end{array}$ & $\begin{array}{l}\text { TC } \\
\% \\
\end{array}$ \\
\hline \multirow[t]{8}{*}{69} & FS04WV025001A1 & East & Back slope & 34.0 & 0.93 & 15.4 \\
\hline & FS04WV025001A2 & East & Back slope & 17.1 & 0.54 & 9.92 \\
\hline & FS04WV025001AB & East & Back slope & 10.9 & 0.27 & 4.56 \\
\hline & FS04WV025001Bw1 & East & Back slope & 6.2 & 0.14 & 1.85 \\
\hline & FS04WV025001Bw2 & East & Back slope & 4.9 & 0.09 & 1.13 \\
\hline & FS04WV025001Bw3 & East & Back slope & 5.6 & 0.11 & 1.50 \\
\hline & FS04WV025001Bw4 & East & Back slope & 4.2 & 0.07 & 0.93 \\
\hline & FS04WV025001BC & East & Back slope & 3.4 & 0.05 & 0.72 \\
\hline \multirow[t]{7}{*}{71} & FS04WV025002A & East & Back slope & 18.0 & 0.57 & 7.67 \\
\hline & FS04WV025002AB & East & Back slope & 9.3 & 0.24 & 2.78 \\
\hline & FS04WV025002Bw1 & East & Back slope & 7.5 & 0.17 & 1.90 \\
\hline & FS04WV025002Bw2 & East & Back slope & 6.3 & 0.12 & 1.37 \\
\hline & FS04WV025002Bw3 & East & Back slope & 6.0 & 0.12 & 1.38 \\
\hline & FS04WV025002BC1 & East & Back slope & 5.4 & 0.10 & 1.04 \\
\hline & FS04WV025002BC2 & East & Back slope & 5.0 & 0.09 & 0.87 \\
\hline \multirow[t]{5}{*}{73} & FS04WV025003A & East & Ridge & 14.0 & 0.41 & 6.33 \\
\hline & FS04WV025003Bw1 & East & Ridge & 7.8 & 0.19 & 2.32 \\
\hline & FS04WV025003Bw2 & East & Ridge & 5.3 & 0.11 & 1.16 \\
\hline & FS04WV025003Bx1 & East & Ridge & 4.0 & 0.06 & 0.57 \\
\hline & FS04WV025003Bx2 & East & Ridge & 3.8 & 0.04 & 0.46 \\
\hline \multirow[t]{8}{*}{75} & FS04WV025004A & East & Foot & 13.8 & 0.44 & 6.54 \\
\hline & FS04WV025004AB & East & Foot & 8.4 & 0.25 & 3.54 \\
\hline & FS04WV025004Bw1 & East & Foot & 6.9 & 0.17 & 2.52 \\
\hline & FS04WV025004Bw2 & East & Foot & 4.5 & 0.08 & 1.01 \\
\hline & FS04WV025004Bw3 & East & Foot & 3.5 & 0.06 & 0.69 \\
\hline & FS04WV025004Bw43 & East & Foot & 3.2 & 0.04 & 0.44 \\
\hline & FS04WV025004Bx & East & Foot & 3.2 & 0.04 & 0.47 \\
\hline & FS04WV025004BC & East & Foot & 3.4 & 0.03 & 0.31 \\
\hline \multirow[t]{7}{*}{77} & FS04WV025005A & East & Bench & 20.1 & 0.64 & 10.9 \\
\hline & FS04WV025005AB & East & Bench & 13.9 & 0.37 & 7.13 \\
\hline & FS04WV025005Bw1 & East & Bench & 8.7 & 0.17 & 3.00 \\
\hline & FS04WV025005Bw2 & East & Bench & 8.3 & 0.13 & 3.01 \\
\hline & FS04WV025005Bx1 & East & Bench & 7.3 & 0.12 & 2.76 \\
\hline & FS04WV025005Bx2 & East & Bench & 8.9 & 0.11 & 3.53 \\
\hline & FS04WV025005Btx3 & East & Bench & 5.5 & 0.05 & 0.38 \\
\hline
\end{tabular}




\begin{tabular}{|c|c|c|c|c|c|c|}
\hline $\begin{array}{l}\text { Descrip. } \\
\text { Page \# }\end{array}$ & Sample ID & $\begin{array}{l}\text { Wshed } \\
\text { Area }\end{array}$ & $\begin{array}{l}\text { Landscape } \\
\text { Position }\end{array}$ & $\begin{array}{c}\text { LOI } \\
\%\end{array}$ & $\begin{array}{l}\text { TN } \\
\%\end{array}$ & $\begin{array}{l}\text { TC } \\
\%\end{array}$ \\
\hline & FS04WV025005BC & East & Bench & 5.0 & 0.05 & 0.31 \\
\hline \multirow[t]{6}{*}{79} & FS04WV025010A/E & East & Shoulder & 21.6 & 0.72 & 10.3 \\
\hline & FS04WV025010BA & East & Shoulder & 7.2 & 0.21 & 2.27 \\
\hline & FS04WV025010Bt & East & Shoulder & 5.6 & 0.12 & 1.15 \\
\hline & FS04WV025010Btx1 & East & Shoulder & 4.7 & 0.06 & 0.75 \\
\hline & FS04WV025010Btx2 & East & Shoulder & 4.5 & 0.05 & 0.65 \\
\hline & FS04WV025010BC & East & Shoulder & 3.9 & 0.05 & 0.42 \\
\hline \multirow[t]{5}{*}{81} & FS04WV025019A & East & Floodplain & 15.2 & 0.53 & 8.09 \\
\hline & FS04WV025019Bw1 & East & Floodplain & 8.7 & 0.24 & 3.02 \\
\hline & FS04WV025019BW2 & East & Floodplain & 9.6 & 0.25 & 3.14 \\
\hline & FS04WV025019Bw3 & East & Floodplain & 7.2 & 0.19 & 2.57 \\
\hline & FS04WV025019BC & East & Floodplain & 2.7 & 0.04 & 0.36 \\
\hline \multirow[t]{5}{*}{83} & FS04WV101001A & East & Ridge & 19.4 & 0.61 & 9.71 \\
\hline & FS04WV101001BA & East & Ridge & 13.7 & 0.35 & 6.72 \\
\hline & FS04WV101001Bt1 & East & Ridge & 8.5 & 0.18 & 2.85 \\
\hline & FS04WV101001Bt2 & East & Ridge & 5.8 & 0.10 & 1.25 \\
\hline & FS04WV101001Bt3 & East & Ridge & 5.6 & 0.09 & 1.15 \\
\hline \multirow[t]{6}{*}{84} & FS04WV067007A & East & Shoulder & 14.7 & 0.38 & 7.82 \\
\hline & FS04WV067007BA & East & Shoulder & 8.3 & 0.16 & 3.14 \\
\hline & FS04WV067007Bw1 & East & Shoulder & 7.1 & 0.11 & 2.00 \\
\hline & FS04WV067007Bw2 & East & Shoulder & 5.8 & 0.08 & 1.36 \\
\hline & FS04WV067007Bw3 & East & Shoulder & 3.5 & 0.04 & 0.52 \\
\hline & FS04WV067007BC & East & Shoulder & 3.7 & 0.04 & 0.41 \\
\hline \multirow[t]{7}{*}{85} & FS04WV067001A & West & Back slope & 13.6 & 0.43 & 8.09 \\
\hline & FS04WV067001AB & West & Back slope & 5.1 & 0.09 & 1.84 \\
\hline & FS04WV067001Bw1 & West & Back slope & 3.0 & 0.04 & 0.71 \\
\hline & FS04WV067001BW2 & West & Back slope & 2.7 & 0.03 & 0.30 \\
\hline & FS04WV067001Bw3 & West & Back slope & 2.0 & 0.02 & 0.16 \\
\hline & FS04WV067001BC & West & Back slope & 1.8 & 0.02 & 0.13 \\
\hline & FS04WV067001C & West & Back slope & 1.3 & 0.01 & 0.07 \\
\hline \multirow[t]{4}{*}{87} & FS04WV067002A & West & Ridge & 9.8 & 0.29 & 4.79 \\
\hline & FS04WV067002BA & West & Ridge & 5.5 & 0.10 & 1.74 \\
\hline & FS04WV067002Bw1 & West & Ridge & 3.6 & 0.08 & 1.14 \\
\hline & FS04WV067002BW2 & West & Ridge & 2.1 & 0.04 & 0.39 \\
\hline \multirow[t]{2}{*}{88} & FS04WV067003A & West & Ridge & 18.8 & 0.44 & 7.70 \\
\hline & FS04WV067003AB & West & Ridge & 8.3 & 0.23 & 3.45 \\
\hline
\end{tabular}




\begin{tabular}{|c|c|c|c|c|c|c|}
\hline $\begin{array}{l}\text { Descrip. } \\
\text { Page \# }\end{array}$ & Sample ID & $\begin{array}{l}\text { Wshed } \\
\text { Area }\end{array}$ & $\begin{array}{l}\text { Landscape } \\
\text { Position }\end{array}$ & $\begin{array}{c}\text { LOI } \\
\%\end{array}$ & $\begin{array}{l}\text { TN } \\
\%\end{array}$ & $\begin{array}{l}\text { TC } \\
\%\end{array}$ \\
\hline & FS04WV067003Bw1 & West & Ridge & 3.5 & 0.06 & 0.86 \\
\hline & FS04WV067003Bw2 & West & Ridge & 2.3 & 0.03 & 0.31 \\
\hline & FS04WV067003BC & West & Ridge & 2.1 & 0.02 & 0.19 \\
\hline \multirow[t]{8}{*}{89} & FS04WV067004A & West & Floodplain & 7.3 & 0.23 & 3.69 \\
\hline & FS04WV067004BA & West & Floodplain & 4.5 & 0.11 & 1.69 \\
\hline & FS04WV067004Bw1 & West & Floodplain & 3.0 & 0.04 & 0.48 \\
\hline & FS04WV067004Bw2 & West & Floodplain & 4.2 & 0.07 & 0.82 \\
\hline & FS04WV067004Ab & West & Floodplain & 3.2 & 0.06 & 0.76 \\
\hline & FS04WV067004C1 & West & Floodplain & 2.7 & 0.08 & 1.02 \\
\hline & FS04WV067004C2 & West & Floodplain & 1.0 & 0.02 & 0.24 \\
\hline & FS04WV067004C3 & West & Floodplain & 1.4 & 0.02 & 0.26 \\
\hline \multirow[t]{8}{*}{91} & FS04WV067005A & West & Bench & 11.9 & 0.34 & 6.39 \\
\hline & FS04WV067005AB & West & Bench & 7.8 & 0.20 & 3.68 \\
\hline & FS04WV067005Bw1 & West & Bench & 5.6 & 0.12 & 1.97 \\
\hline & FS04WV067005Bw2 & West & Bench & 3.9 & 0.07 & 0.88 \\
\hline & FS04WV067005Bw3 & West & Bench & 2.9 & 0.03 & 0.23 \\
\hline & FS04WV067005Bx1 & West & Bench & 3.9 & 0.03 & 0.16 \\
\hline & FS04WV067005Bx2 & West & Bench & 4.1 & 0.04 & 0.13 \\
\hline & FS04WV067005C & West & Bench & 4.6 & 0.03 & 0.17 \\
\hline \multirow[t]{6}{*}{93} & FS04WV067006A & West & Foot & 12.1 & 0.44 & 5.07 \\
\hline & FS04WV067006AB & West & Foot & 7.9 & 0.23 & 2.52 \\
\hline & FS04WV067006Bw1 & West & Foot & 5.1 & 0.09 & 1.01 \\
\hline & FS04WV067006Bw2 & West & Foot & 4.3 & 0.06 & 0.60 \\
\hline & FS04WV067006Bw3 & West & Foot & 3.7 & 0.04 & 0.40 \\
\hline & FS04WV067006BC & West & Foot & 3.4 & 0.04 & 0.31 \\
\hline \multirow[t]{6}{*}{95} & FS04WV067017A1 & West & Shoulder & 9.8 & 0.20 & 4.73 \\
\hline & FS04WV067017A2 & West & Shoulder & 6.4 & 0.13 & 2.85 \\
\hline & FS04WV067017BA & West & Shoulder & 5.2 & 0.09 & 1.89 \\
\hline & FS04WV067017Bw & West & Shoulder & 3.7 & 0.05 & 0.85 \\
\hline & FS04WV067017BC & West & Shoulder & 2.1 & 0.03 & 0.25 \\
\hline & FS04WV067017C & West & Shoulder & 2.4 & 0.03 & 0.50 \\
\hline \multirow[t]{3}{*}{96} & FS04WV025006A & East & Back slope & 15.7 & 0.45 & 7.65 \\
\hline & FS04WV025006BA & East & Back slope & 10.9 & 0.28 & 5.07 \\
\hline & FS04WV025006Bt & East & Back slope & 7.6 & 0.21 & 3.97 \\
\hline \multirow[t]{3}{*}{96} & FS04WV025007A & East & Bench & 22.4 & 0.73 & 11.8 \\
\hline & FS04WV025007BA & East & Bench & 8.4 & 0.22 & 3.20 \\
\hline & FS04WV025007Bw & East & Bench & 8.3 & 0.19 & 2.88 \\
\hline
\end{tabular}




\begin{tabular}{|c|c|c|c|c|c|c|}
\hline $\begin{array}{l}\text { Descrip. } \\
\text { Page \# }\end{array}$ & Sample ID & $\begin{array}{l}\text { Wshed } \\
\text { Area }\end{array}$ & $\begin{array}{l}\text { Landscape } \\
\text { Position }\end{array}$ & $\begin{array}{c}\text { LOI } \\
\%\end{array}$ & $\begin{array}{l}\text { TN } \\
\%\end{array}$ & $\begin{array}{l}\text { TC } \\
\%\end{array}$ \\
\hline \multirow[t]{2}{*}{97} & FS04WV025008A & East & Floodplain & 24.3 & 0.65 & 11.8 \\
\hline & FS04WV025008Bt & East & Floodplain & 11.0 & 0.24 & 3.78 \\
\hline \multirow[t]{2}{*}{97} & FS04WV025009A & East & Foot & 16.7 & 0.56 & 7.65 \\
\hline & FS04WV025009Bt & East & Foot & 8.5 & 0.25 & 2.58 \\
\hline \multirow[t]{3}{*}{98} & FS04WV025011A & East & Shoulder & 12.6 & 0.43 & 5.22 \\
\hline & FS04WV025011BA & East & Shoulder & 7.7 & 0.20 & 2.46 \\
\hline & FS04WV025011Bt & East & Shoulder & 6.3 & 0.14 & 1.92 \\
\hline \multirow[t]{2}{*}{98} & FS04WV025012A & East & Bench & 17.1 & 0.62 & 8.01 \\
\hline & FS04WV025012Bw & East & Bench & 8.9 & 0.25 & 3.03 \\
\hline \multirow[t]{3}{*}{99} & FS04WV025013A & East & Ridge & 15.8 & 0.47 & 7.46 \\
\hline & FS04WV025013BA & East & Ridge & 6.7 & 0.19 & 2.88 \\
\hline & FS04WV025013Bt & East & Ridge & 7.9 & 0.18 & 2.28 \\
\hline \multirow[t]{3}{*}{99} & FS04WV025014A & East & Back slope & 12.4 & 0.43 & 5.25 \\
\hline & FS04WV025014BA & East & Back slope & 6.7 & 0.17 & 1.93 \\
\hline & FS04WV025014Bt & East & Back slope & 6.4 & 0.14 & 1.47 \\
\hline \multirow[t]{2}{*}{100} & FS04WV025015A & East & Shoulder & 17.1 & 0.45 & 7.16 \\
\hline & FS04WV025015Bt & East & Shoulder & 8.0 & 0.18 & 2.41 \\
\hline \multirow[t]{3}{*}{100} & FS04WV067008A & West & Foot & 8.1 & 0.29 & 3.73 \\
\hline & FS04WV067008BA & West & Foot & 5.8 & 0.16 & 1.93 \\
\hline & FS04WV067008Bw & West & Foot & 5.1 & 0.10 & 1.18 \\
\hline \multirow[t]{3}{*}{101} & FS04WV067009A & West & Floodplain & 8.0 & 0.24 & 4.78 \\
\hline & FS04WV067009BA & West & Floodplain & 2.8 & 0.08 & 2.01 \\
\hline & FS04WV067009Bg & West & Floodplain & 3.5 & 0.09 & 2.18 \\
\hline \multirow[t]{3}{*}{101} & FS04WV067010A & West & Back slope & 11.0 & 0.30 & 5.01 \\
\hline & FS04WV067010BA & West & Back slope & 6.8 & 0.17 & 2.28 \\
\hline & FS04WV067010Bw & West & Back slope & 6.2 & 0.14 & 1.86 \\
\hline \multirow[t]{2}{*}{102} & FS04WV067011BA & West & Floodplain & 3.8 & 0.09 & 1.89 \\
\hline & FS04WV067011Bw & West & Floodplain & 2.2 & 0.05 & 0.78 \\
\hline \multirow[t]{3}{*}{102} & FS04WV067012A & West & Ridge & 18.0 & 0.53 & 8.52 \\
\hline & FS04WV067012BA & West & Ridge & 9.4 & 0.22 & 3.31 \\
\hline & FS04WV067012Bw & West & Ridge & 6.7 & 0.13 & 1.69 \\
\hline
\end{tabular}




\begin{tabular}{|c|c|c|c|c|c|c|}
\hline $\begin{array}{l}\text { Descrip. } \\
\text { Page \# }\end{array}$ & Sample ID & $\begin{array}{l}\text { Wshed } \\
\text { Area }\end{array}$ & $\begin{array}{l}\text { Landscape } \\
\text { Position }\end{array}$ & $\begin{array}{c}\text { LOI } \\
\%\end{array}$ & $\begin{array}{l}\text { TN } \\
\%\end{array}$ & $\begin{array}{l}\text { TC } \\
\%\end{array}$ \\
\hline \multirow[t]{3}{*}{103} & FS04WV067013A & West & Back slope & 16.4 & 0.48 & 8.98 \\
\hline & FS04WV067013BA & West & Back slope & 5.9 & 0.13 & 2.20 \\
\hline & FS04WV067013Bw & West & Back slope & 4.3 & 0.08 & 1.33 \\
\hline \multirow[t]{3}{*}{103} & FS04WV067014A & West & Bench & 15.0 & 0.44 & 6.95 \\
\hline & FS04WV067014BA & West & Bench & 6.5 & 0.14 & 2.05 \\
\hline & FS04WV067014Bw & West & Bench & 5.2 & 0.10 & 1.30 \\
\hline \multirow[t]{3}{*}{104} & FS04WV067015A & West & Shoulder & 11.9 & 0.42 & 5.70 \\
\hline & FS04WV067015BA & West & Shoulder & 7.8 & 0.24 & 2.99 \\
\hline & FS04WV067015Bw & West & Shoulder & 5.1 & 0.13 & 1.43 \\
\hline \multirow[t]{3}{*}{104} & FS04WV067016A & West & Ridge & 11.7 & 0.35 & 6.79 \\
\hline & FS04WV067016BA & West & Ridge & 6.6 & 0.15 & 2.86 \\
\hline & FS04WV067016Bt & West & Ridge & 3.2 & 0.06 & 0.73 \\
\hline \multirow[t]{3}{*}{105} & FS04WV025016A & East & Floodplain & 19.7 & 0.53 & 8.67 \\
\hline & FS04WV025016BA & East & Floodplain & 12.0 & 0.31 & 4.73 \\
\hline & FS04WV025016Bw & East & Floodplain & 6.5 & 0.13 & 1.94 \\
\hline \multirow[t]{3}{*}{105} & FS04WV025017A & East & Back slope & 13.3 & 0.41 & 6.80 \\
\hline & FS04WV025017BA & East & Back slope & 8.8 & 0.22 & 2.97 \\
\hline & FS04WV025017Bt & East & Back slope & 8.0 & 0.19 & 2.50 \\
\hline \multirow[t]{2}{*}{106} & FS04WV025018A & East & Foot & 19.8 & 0.53 & 9.26 \\
\hline & FS04WV025018Bw & East & Foot & 4.2 & 0.09 & 1.06 \\
\hline \multirow[t]{3}{*}{106} & FS04WV067018A & West & Foot & 8.9 & 0.30 & 4.77 \\
\hline & FS04WV067018BA & West & Foot & 6.3 & 0.13 & 2.60 \\
\hline & FS04WV067018Bt & West & Foot & 3.6 & 0.07 & 1.24 \\
\hline \multirow[t]{3}{*}{107} & FS04WV067019A & West & Bench & 12.7 & 0.43 & 7.32 \\
\hline & FS04WV067019BA & West & Bench & 6.7 & 0.16 & 2.82 \\
\hline & FS04WV067019Bw & West & Bench & 3.7 & 0.07 & 1.01 \\
\hline \multirow[t]{3}{*}{107} & FS04WV067020A & West & Shoulder & 10.3 & 0.30 & 6.66 \\
\hline & FS04WV067020BA & West & Shoulder & 5.5 & 0.14 & 3.16 \\
\hline & FS04WV067020Bt & West & Shoulder & 4.5 & 0.09 & 1.85 \\
\hline \multirow[t]{3}{*}{108} & FS04WV067021A & West & Ridge & 9.8 & 0.31 & 5.60 \\
\hline & FS04WV067021BA & West & Ridge & 5.1 & 0.13 & 2.43 \\
\hline & FS04WV067021Bw & West & Ridge & 4.2 & 0.09 & 1.54 \\
\hline
\end{tabular}




\begin{tabular}{|c|c|c|c|c|c|c|}
\hline $\begin{array}{l}\text { Descrip. } \\
\text { Page \# }\end{array}$ & Sample ID & $\begin{array}{l}\text { Wshed } \\
\text { Area }\end{array}$ & $\begin{array}{l}\text { Landscape } \\
\text { Position }\end{array}$ & $\begin{array}{c}\text { LOI } \\
\%\end{array}$ & $\begin{array}{l}\text { TN } \\
\%\end{array}$ & $\begin{array}{l}\text { TC } \\
\%\end{array}$ \\
\hline \multirow[t]{3}{*}{108} & FS04WV067022A1 & West & Shoulder & 6.5 & 0.19 & 3.45 \\
\hline & FS04WV067022A2 & West & Shoulder & 2.3 & 0.07 & 1.38 \\
\hline & FS04WV067022AB & West & Shoulder & 2.7 & 0.08 & 1.50 \\
\hline \multirow[t]{3}{*}{109} & FS04WV067023A & West & Ridge & 15.9 & 0.43 & 8.86 \\
\hline & FS04WV067023BA & West & Ridge & 7.4 & 0.16 & 2.98 \\
\hline & FS04WV067023Bw & West & Ridge & 5.2 & 0.08 & 1.31 \\
\hline \multirow[t]{2}{*}{109} & FS04WV067024BA & West & Back slope & 12.6 & 0.31 & 5.94 \\
\hline & FS04WV067024Bt & West & Back slope & 8.6 & 0.17 & 3.39 \\
\hline \multirow[t]{3}{*}{110} & FS04WV025020A & East & Bench & 8.0 & 0.25 & 4.91 \\
\hline & FS04WV025020BA & East & Bench & 6.5 & 0.16 & 5.03 \\
\hline & FS04WV025020Bt & East & Bench & 3.9 & 0.08 & 0.71 \\
\hline \multirow[t]{3}{*}{110} & FS04WV025021A & East & Back slope & 14.9 & 0.49 & 6.83 \\
\hline & FS04WV025021BA & East & Back slope & 7.3 & 0.25 & 2.48 \\
\hline & FS04WV025021Bw & East & Back slope & 6.5 & 0.19 & 1.76 \\
\hline \multirow[t]{3}{*}{111} & FS04WV101002A & East & Ridge & 11.2 & 0.35 & 4.27 \\
\hline & FS04WV101002BA & East & Ridge & 8.2 & 0.24 & 3.01 \\
\hline & FS04WV101002Bt & East & Ridge & 9.2 & 0.24 & 3.12 \\
\hline \multirow[t]{3}{*}{111} & FS04WV067025A & West & Ridge & 8.5 & 0.18 & 4.35 \\
\hline & FS04WV067025BA & West & Ridge & 3.9 & 0.07 & 1.30 \\
\hline & FS04WV067025Bw & West & Ridge & 2.6 & 0.04 & 0.68 \\
\hline \multirow[t]{3}{*}{112} & FS04WV067026A & West & Ridge & 32.3 & 0.54 & 18.5 \\
\hline & FS04WV067026BA & West & Ridge & 11.9 & 0.24 & 6.06 \\
\hline & FS04WV067026Bw & West & Ridge & 6.6 & 0.13 & 2.71 \\
\hline \multirow[t]{3}{*}{112} & FS04WV067027A & West & Shoulder & 8.6 & 0.19 & 4.23 \\
\hline & FS04WV067027BA & West & Shoulder & 5.6 & 0.10 & 2.41 \\
\hline & FS04WV067027Bt & West & Shoulder & 4.3 & 0.07 & 1.18 \\
\hline \multirow[t]{3}{*}{113} & FS04WV067028A1 & West & Back slope & 13.1 & 0.44 & 6.57 \\
\hline & FS04WV067028A2 & West & Back slope & 8.7 & 0.26 & 3.58 \\
\hline & FS04WV067028Bw & West & Back slope & 5.1 & 0.12 & 1.67 \\
\hline \multirow[t]{3}{*}{113} & FS04WV067029A & West & Back slope & 10.9 & 0.23 & 4.90 \\
\hline & FS04WV067029BA & West & Back slope & 6.4 & 0.12 & 2.17 \\
\hline & FS04WV067029Bw & West & Back slope & 5.5 & 0.09 & 1.44 \\
\hline
\end{tabular}




\begin{tabular}{|c|c|c|c|c|c|c|}
\hline $\begin{array}{l}\text { Descrip. } \\
\text { Page \# }\end{array}$ & Sample ID & $\begin{array}{l}\text { Wshed } \\
\text { Area }\end{array}$ & $\begin{array}{l}\text { Landscape } \\
\text { Position }\end{array}$ & $\begin{array}{c}\text { LOI } \\
\%\end{array}$ & $\begin{array}{l}\text { TN } \\
\%\end{array}$ & $\begin{array}{l}\text { TC } \\
\%\end{array}$ \\
\hline \multirow[t]{3}{*}{114} & FS04WV067030A & West & Bench & 9.8 & 0.31 & 4.15 \\
\hline & FS04WV067030BA & West & Bench & 8.6 & 0.23 & 3.55 \\
\hline & FS04WV067030Bt & West & Bench & 6.9 & 0.15 & 2.31 \\
\hline \multirow[t]{3}{*}{114} & FS04WV067031A & West & Bench & 13.3 & 0.41 & 7.11 \\
\hline & FS04WV067031BA & West & Bench & 8.9 & 0.23 & 3.87 \\
\hline & FS04WV067031BW & West & Bench & 4.6 & 0.08 & 1.06 \\
\hline \multirow[t]{2}{*}{115} & FS04WV067032A & West & Foot & 8.9 & 0.25 & 4.72 \\
\hline & FS04WV067032Bt & West & Foot & 4.5 & 0.09 & 1.42 \\
\hline \multirow[t]{3}{*}{115} & FS04WV025023A & East & Shoulder & 10.3 & 0.30 & 3.54 \\
\hline & FS04WV025023BA & East & Shoulder & 6.4 & 0.13 & 1.47 \\
\hline & FS04WV025023Bt & East & Shoulder & 6.1 & 0.12 & 1.28 \\
\hline \multirow[t]{3}{*}{116} & FS04WV025024A & East & Back slope & 19.7 & 0.52 & 10.1 \\
\hline & FS04WV025024BA & East & Back slope & 7.9 & 0.16 & 2.71 \\
\hline & FS04WV025024BW & East & Back slope & 7.4 & 0.15 & 2.62 \\
\hline \multirow[t]{3}{*}{116} & FS04WV025025A & East & Bench & 19.3 & 0.61 & 10.9 \\
\hline & FS04WV025025BA & East & Bench & 8.6 & 0.22 & 3.32 \\
\hline & FS04WV025025Bt & East & Bench & 6.8 & 0.16 & 2.53 \\
\hline \multirow[t]{3}{*}{117} & FS04WV067033A1 & East & Floodplain & 20.2 & 0.58 & 10.5 \\
\hline & FS04WV067033A2 & East & Floodplain & 13.0 & 0.34 & 6.18 \\
\hline & FS04WV067033BA & East & Floodplain & 10.6 & 0.30 & 5.23 \\
\hline \multirow[t]{3}{*}{117} & FS04WV067034A & East & Back slope & 12.1 & 0.27 & 5.98 \\
\hline & FS04WV067034BA & East & Back slope & 7.8 & 0.16 & 3.47 \\
\hline & FS04WV067034Bt & East & Back slope & 6.0 & 0.10 & 1.65 \\
\hline \multirow[t]{3}{*}{118} & FS04WV101003A & East & Back slope & 11.0 & 0.32 & 5.20 \\
\hline & FS04WV101003BA & East & Back slope & 6.9 & 0.16 & 2.41 \\
\hline & FS04WV101003Bt & East & Back slope & 5.5 & 0.11 & 1.38 \\
\hline \multirow[t]{3}{*}{118} & FS04WV101004A & East & Ridge & 14.6 & 0.44 & 7.42 \\
\hline & FS04WV101004BA & East & Ridge & 8.5 & 0.23 & 3.64 \\
\hline & FS04WV101004Bt & East & Ridge & 7.6 & 0.20 & 2.98 \\
\hline \multirow[t]{3}{*}{119} & FS04WV101005A1 & East & Bench & 3.4 & 0.11 & 1.56 \\
\hline & FS04WV101005A2 & East & Bench & 4.7 & 0.13 & 2.05 \\
\hline & FS04WV101005Ab & East & Bench & 5.9 & 0.16 & 3.11 \\
\hline
\end{tabular}




\begin{tabular}{llllccc}
\hline $\begin{array}{l}\text { Descrip. } \\
\text { Page \# }\end{array}$ & Sample ID & $\begin{array}{l}\text { Wshed } \\
\text { Area }\end{array}$ & $\begin{array}{l}\text { Landscape } \\
\text { Position }\end{array}$ & $\begin{array}{c}\text { LOI } \\
\%\end{array}$ & $\begin{array}{c}\text { TN } \\
\%\end{array}$ & $\begin{array}{c}\text { TC } \\
\%\end{array}$ \\
\hline 119 & FS04WV101006A & East & Bench & 9.7 & 0.27 & 3.76 \\
\hline & FS04WV101006BA & East & Bench & 9.4 & 0.28 & 3.65 \\
\hline & FS04WV101006Bt & East & Bench & 9.1 & 0.23 & 3.06 \\
\hline 120 & & & & & & \\
\hline & FS04WV025026A & East & Foot & 10.6 & 0.33 & 5.76 \\
\hline & FS04WV025026BA & East & Foot & 5.9 & 0.12 & 1.82 \\
\hline 120 & FS04WV025026Bt & East & Foot & 6.8 & 0.13 & 2.02 \\
\hline & FS04WV025027A & East & Foot & 10.5 & 0.29 & 4.36 \\
\hline & FS04WV025027BA & East & Foot & 7.6 & 0.17 & 2.38 \\
\hline 121 & FS04WV025027Bt & East & Foot & 7.1 & 0.15 & 2.21 \\
\hline & FS04WV025022A & East & Ridge & 14.6 & 0.52 & 7.16 \\
\hline
\end{tabular}




\section{APPENDIX I ACID RISK DATA}

\begin{tabular}{|c|c|c|c|c|c|c|c|}
\hline $\begin{array}{l}\text { Descrip. } \\
\text { Page \# }\end{array}$ & Sample ID & $\begin{array}{l}\text { Wshed } \\
\text { Area }\end{array}$ & $\begin{array}{l}\text { Landscape } \\
\text { Position }\end{array}$ & $\begin{array}{c}\mathrm{Ca} \\
\mathrm{mg} / \mathrm{kg}\end{array}$ & $\begin{array}{c}\mathrm{Al} \\
\mathrm{mg} / \mathrm{kg}\end{array}$ & $\begin{array}{l}\text { Ca:Al } \\
\text { Ratio }\end{array}$ & $\begin{array}{c}\text { BSECEC } \\
\% \\
\end{array}$ \\
\hline \multirow[t]{8}{*}{69} & FS04WV025001A1 & East & Back slope & 75.83 & 9.80 & 5.10 & 38.3 \\
\hline & FS04WV025001A2 & East & Back slope & 45.11 & 15.40 & 1.90 & 16.4 \\
\hline & FS04WV025001AB & East & Back slope & 30.51 & 56.90 & 0.40 & 4.6 \\
\hline & FS04WV025001Bw1 & East & Back slope & 8.42 & 19.10 & 0.30 & 4.5 \\
\hline & FS04WV025001Bw2 & East & Back slope & 4.87 & 12.60 & 0.30 & 5.9 \\
\hline & FS04WV025001Bw3 & East & Back slope & 5.19 & 13.60 & 0.30 & 5.4 \\
\hline & FS04WV025001Bw4 & East & Back slope & 2.63 & 12.80 & 0.10 & 5.5 \\
\hline & FS04WV025001BC & East & Back slope & 6.28 & 10.30 & 0.40 & 6.5 \\
\hline \multirow[t]{7}{*}{71} & FS04WV025002A & East & Back slope & 49.72 & 19.09 & 1.72 & 16.4 \\
\hline & FS04WV025002AB & East & Back slope & 16.41 & 31.78 & 0.34 & 7.1 \\
\hline & FS04WV025002Bw1 & East & Back slope & 8.96 & 27.96 & 0.21 & 5.2 \\
\hline & FS04WV025002Bw2 & East & Back slope & 8.26 & 27.89 & 0.20 & 7.5 \\
\hline & FS04WV025002Bw3 & East & Back slope & 22.02 & 22.57 & 0.64 & 4.5 \\
\hline & FS04WV025002BC1 & East & Back slope & 6.08 & 26.44 & 0.15 & 4.9 \\
\hline & FS04WV025002BC2 & East & Back slope & 5.71 & 29.50 & 0.13 & 4.5 \\
\hline \multirow[t]{5}{*}{73} & FS04WV025003A & East & Ridge & 27.93 & 23.40 & 0.80 & 7.6 \\
\hline & FS04WV025003Bw1 & East & Ridge & 11.59 & 45.50 & 0.20 & 3.8 \\
\hline & FS04WV025003Bw2 & East & Ridge & 5.83 & 26.90 & 0.10 & 3.8 \\
\hline & FS04WV025003Bx1 & East & Ridge & 5.15 & 25.90 & 0.10 & 5.0 \\
\hline & FS04WV025003Bx2 & East & Ridge & 4.25 & 35.50 & 0.10 & 3.8 \\
\hline \multirow[t]{8}{*}{75} & FS04WV025004A & East & Foot & 34.11 & 12.60 & 1.80 & 20.4 \\
\hline & FS04WV025004AB & East & Foot & 22.10 & 42.90 & 0.30 & 6.8 \\
\hline & FS04WV025004Bw1 & East & Foot & 43.05 & 25.00 & 1.10 & 5.2 \\
\hline & FS04WV025004Bw2 & East & Foot & 4.38 & 17.90 & 0.20 & 6.4 \\
\hline & FS04WV025004Bw3 & East & Foot & 2.69 & 17.60 & 0.10 & 7.0 \\
\hline & FS04WV025004Bw4 & East & Foot & 3.40 & 27.10 & 0.10 & 6.2 \\
\hline & FS04WV025004Bx & East & Foot & 7.89 & 27.10 & 0.20 & 6.0 \\
\hline & FS04WV025004BC & East & Foot & 5.69 & 24.30 & 0.20 & 7.3 \\
\hline \multirow[t]{7}{*}{77} & FS04WV025005A & East & Bench & 17.50 & 18.60 & 0.60 & 11.6 \\
\hline & FS04WV025005AB & East & Bench & 3.77 & 24.00 & 0.10 & 3.6 \\
\hline & FS04WV025005Bw1 & East & Bench & 4.20 & 19.40 & 0.10 & 4.7 \\
\hline & FS04WV025005Bw2 & East & Bench & 3.98 & 22.10 & 0.10 & 4.4 \\
\hline & FS04WV025005Bx1 & East & Bench & 3.88 & 25.00 & 0.10 & 4.4 \\
\hline & FS04WV025005Bx2 & East & Bench & 1.59 & 24.60 & 0.00 & 4.6 \\
\hline & FS04WV025005Bx3 & East & Bench & 5.61 & 36.90 & 0.10 & 5.7 \\
\hline
\end{tabular}




\begin{tabular}{|c|c|c|c|c|c|c|c|}
\hline $\begin{array}{l}\text { Descrip. } \\
\text { Page \# }\end{array}$ & Sample ID & $\begin{array}{l}\text { Wshed } \\
\text { Area }\end{array}$ & $\begin{array}{l}\text { Landscape } \\
\text { Position }\end{array}$ & $\begin{array}{c}\mathrm{Ca} \\
\mathrm{mg} / \mathrm{kg}\end{array}$ & $\begin{array}{c}\mathrm{Al} \\
\mathrm{mg} / \mathrm{kg}\end{array}$ & $\begin{array}{l}\text { Ca:Al } \\
\text { Ratio }\end{array}$ & $\begin{array}{c}\text { BSECEC } \\
\% \\
\end{array}$ \\
\hline & FS04WV025005BC & East & Bench & 7.78 & 42.50 & 0.10 & 6.7 \\
\hline \multirow[t]{6}{*}{79} & FS04WV025010A/E & East & Shoulder & 39.93 & 23.80 & 1.10 & 17.0 \\
\hline & FS04WV025010BA & East & Shoulder & 12.45 & 39.40 & 0.20 & 5.6 \\
\hline & FS04WV025010Bt & East & Shoulder & 9.26 & 31.40 & 0.20 & 5.3 \\
\hline & FS04WV025010Btx1 & East & Shoulder & 8.93 & 26.50 & 0.20 & 6.9 \\
\hline & FS04WV025010Btx2 & East & Shoulder & 10.76 & 29.20 & 0.20 & 6.0 \\
\hline & FS04WV025010BC & East & Shoulder & 11.32 & 27.40 & 0.30 & 7.0 \\
\hline \multirow[t]{5}{*}{81} & FS04WV025019A & East & Floodplain & 18.30 & 23.10 & 0.50 & 13.7 \\
\hline & FS04WV025019Bw1 & East & Floodplain & 22.91 & 20.30 & 0.70 & 10.5 \\
\hline & FS04WV025019Bw2 & East & Floodplain & 24.10 & 14.10 & 1.10 & 10.8 \\
\hline & FS04WV025019Bw3 & East & Floodplain & 7.33 & 6.70 & 0.70 & 13.3 \\
\hline & FS04WV025019BC & East & Floodplain & 33.33 & 13.90 & 1.60 & 22.1 \\
\hline \multirow[t]{5}{*}{83} & FS04WV101001A & East & Ridge & 67.90 & 12.20 & 3.70 & 21.4 \\
\hline & FS04WV101001BA & East & Ridge & 38.63 & 46.40 & 0.50 & 5.9 \\
\hline & FS04WV101001Bt1 & East & Ridge & 7.88 & 39.30 & 0.10 & 3.7 \\
\hline & FS04WV101001Bt2 & East & Ridge & 4.15 & 31.40 & 0.10 & 3.9 \\
\hline & FS04WV101001Bt3 & East & Ridge & 3.40 & 31.20 & 0.10 & 3.4 \\
\hline \multirow[t]{6}{*}{84} & FS04WV067007A & East & Shoulder & 20.94 & 49.60 & 0.28 & 5.3 \\
\hline & FS04WV067007BA & East & Shoulder & 10.66 & 21.49 & 0.33 & 4.2 \\
\hline & FS04WV067007Bw1 & East & Shoulder & 4.75 & 8.69 & 0.36 & 5.9 \\
\hline & FS04WV067007Bw2 & East & Shoulder & 3.43 & 10.10 & 0.22 & 3.9 \\
\hline & FS04WV067007Bw3 & East & Shoulder & 3.63 & 22.44 & 0.11 & 3.4 \\
\hline & FS04WV067007BC & East & Shoulder & 2.14 & 27.95 & 0.05 & 3.6 \\
\hline \multirow[t]{7}{*}{85} & FS04WV067001A & West & Back slope & 49.58 & 10.16 & 3.23 & 27.1 \\
\hline & FS04WV067001AB & West & Back slope & 14.45 & 17.97 & 0.53 & 8.6 \\
\hline & FS04WV067001Bw1 & West & Back slope & 7.00 & 22.46 & 0.21 & 7.1 \\
\hline & FS04WV067001Bw2 & West & Back slope & 4.58 & 27.49 & 0.11 & 5.4 \\
\hline & FS04WV067001Bw3 & West & Back slope & 5.91 & 28.32 & 0.14 & 6.2 \\
\hline & FS04WV067001BC & West & Back slope & 7.52 & 26.85 & 0.19 & 7.3 \\
\hline & FS04WV067001C & West & Back slope & 5.00 & 19.22 & 0.17 & 9.1 \\
\hline \multirow[t]{4}{*}{87} & FS04WV067002A & West & Ridge & 6.48 & 18.70 & 0.20 & 7.5 \\
\hline & FS04WV067002BA & West & Ridge & 7.02 & 13.10 & 0.40 & 5.5 \\
\hline & FS04WV067002Bw1 & West & Ridge & 4.46 & 17.80 & 0.20 & 10.8 \\
\hline & FS04WV067002Bw2 & West & Ridge & 2.54 & 24.00 & 0.10 & 6.1 \\
\hline \multirow[t]{2}{*}{88} & FS04WV067003A & West & Ridge & 74.97 & 16.12 & 3.07 & 25.7 \\
\hline & FS04WV067003AB & West & Ridge & 55.51 & 29.86 & 1.23 & 13.7 \\
\hline
\end{tabular}




\begin{tabular}{|c|c|c|c|c|c|c|c|}
\hline $\begin{array}{l}\text { Descrip. } \\
\text { Page \# }\end{array}$ & Sample ID & $\begin{array}{l}\text { Wshed } \\
\text { Area }\end{array}$ & $\begin{array}{l}\text { Landscape } \\
\text { Position }\end{array}$ & $\begin{array}{c}\mathrm{Ca} \\
\mathrm{mg} / \mathrm{kg}\end{array}$ & $\begin{array}{c}\text { Al } \\
\mathrm{mg} / \mathrm{kg}\end{array}$ & $\begin{array}{l}\text { Ca:Al } \\
\text { Ratio }\end{array}$ & $\begin{array}{c}\text { BSECEC } \\
\%\end{array}$ \\
\hline & FS04WV067003Bw1 & West & Ridge & 34.71 & 32.47 & 0.71 & 9.6 \\
\hline & FS04WV067003Bw2 & West & Ridge & 18.71 & 27.95 & 0.44 & 8.4 \\
\hline & FS04WV067003BC & West & Ridge & 14.02 & 28.59 & 0.32 & 7.3 \\
\hline \multirow[t]{8}{*}{89} & FS04WV067004A & West & Floodplain & 17.37 & 9.60 & 1.20 & 17.7 \\
\hline & FS04WV067004BA & West & Floodplain & 8.88 & 19.20 & 0.30 & 6.9 \\
\hline & FS04WV067004Bw1 & West & Floodplain & 6.32 & 19.60 & 0.20 & 5.2 \\
\hline & FS04WV067004Bw2 & West & Floodplain & 7.93 & 23.20 & 0.20 & 4.9 \\
\hline & FS04WV067004Ab & West & Floodplain & 15.84 & 16.20 & 0.60 & 10.9 \\
\hline & FS04WV067004C1 & West & Floodplain & 37.02 & 4.30 & 5.60 & 25.3 \\
\hline & FS04WV067004C2 & West & Floodplain & 19.06 & 8.60 & 1.50 & 26.5 \\
\hline & FS04WV067004C3 & West & Floodplain & 53.40 & 0.90 & 39.40 & 75.0 \\
\hline \multirow[t]{8}{*}{91} & FS04WV067005A & West & Bench & 16.48 & 13.10 & 0.80 & 11.1 \\
\hline & FS04WV067005AB & West & Bench & 17.65 & 27.20 & 0.40 & 6.2 \\
\hline & FS04WV067005Bw1 & West & Bench & 7.92 & 17.20 & 0.30 & 5.3 \\
\hline & FS04WV067005Bw2 & West & Bench & 6.29 & 24.50 & 0.20 & 5.7 \\
\hline & FS04WV067005Bw3 & West & Bench & 8.87 & 21.60 & 0.30 & 7.9 \\
\hline & FS04WV067005Bx1 & West & Bench & 13.21 & 23.40 & 0.40 & 11.5 \\
\hline & FS04WV067005Bx2 & West & Bench & 9.59 & 28.00 & 0.20 & 7.8 \\
\hline & FS04WV067005C & West & Bench & 8.66 & 21.80 & 0.30 & 12.1 \\
\hline \multirow[t]{6}{*}{93} & FS04WV067006A & West & Foot & 102.05 & 27.03 & 2.50 & 16.3 \\
\hline & FS04WV067006AB & West & Foot & 37.28 & 32.82 & 0.75 & 8.4 \\
\hline & FS04WV067006Bw1 & West & Foot & 19.74 & 27.13 & 0.48 & 6.3 \\
\hline & FS04WV067006Bw2 & West & Foot & 19.13 & 23.69 & 0.53 & 7.9 \\
\hline & FS04WV067006Bw3 & West & Foot & 42.12 & 19.20 & 1.45 & 15.1 \\
\hline & FS04WV067006BC & West & Foot & 37.47 & 19.77 & 1.25 & 16.6 \\
\hline \multirow[t]{6}{*}{95} & FS04WV067017A1 & West & Shoulder & 3.48 & 20.00 & 0.10 & 5.5 \\
\hline & FS04WV067017A2 & West & Shoulder & 5.87 & 21.00 & 0.20 & 6.2 \\
\hline & FS04WV067017BA & West & Shoulder & 5.47 & 14.30 & 0.30 & 5.8 \\
\hline & FS04WV067017Bw & West & Shoulder & 4.06 & 22.70 & 0.10 & 4.2 \\
\hline & FS04WV067017BC & West & Shoulder & 1.25 & 29.80 & 0.00 & 5.0 \\
\hline & FS04WV067017C & West & Shoulder & 2.01 & 25.00 & 0.10 & 3.7 \\
\hline \multirow[t]{3}{*}{96} & FS04WV025006A & East & Back slope & 25.63 & 12.70 & 1.30 & 13.4 \\
\hline & FS04WV025006BA & East & Back slope & 4.53 & 19.60 & 0.20 & 3.9 \\
\hline & FS04WV025006Bt & East & Back slope & & & & 4.2 \\
\hline \multirow[t]{3}{*}{96} & FS04WV025007A & East & Bench & 30.32 & 14.90 & 1.30 & 15.9 \\
\hline & FS04WV025007BA & East & Bench & 13.62 & 12.30 & 0.70 & 7.2 \\
\hline & FS04WV025007Bw & East & Bench & & & & 8.6 \\
\hline
\end{tabular}




\begin{tabular}{|c|c|c|c|c|c|c|c|}
\hline $\begin{array}{l}\text { Descrip. } \\
\text { Page \# }\end{array}$ & Sample ID & $\begin{array}{l}\text { Wshed } \\
\text { Area }\end{array}$ & $\begin{array}{l}\text { Landscape } \\
\text { Position }\end{array}$ & $\begin{array}{c}\mathrm{Ca} \\
\mathrm{mg} / \mathrm{kg}\end{array}$ & $\begin{array}{c}\mathrm{Al} \\
\mathrm{mg} / \mathrm{kg}\end{array}$ & $\begin{array}{l}\text { Ca:Al } \\
\text { Ratio }\end{array}$ & $\begin{array}{c}\text { BSECEC } \\
\% \\
\end{array}$ \\
\hline \multirow[t]{2}{*}{97} & FS04WV025008A & East & Floodplain & 62.96 & 20.80 & 2.00 & 13.3 \\
\hline & FS04WV025008Bt & East & Floodplain & 19.66 & 41.00 & 0.30 & 4.2 \\
\hline \multirow[t]{2}{*}{97} & FS04WV025009A & East & Foot & 14.91 & 21.50 & 0.50 & 10.6 \\
\hline & FS04WV025009Bt & East & Foot & 14.30 & 22.10 & 0.40 & 6.4 \\
\hline \multirow[t]{3}{*}{98} & FS04WV025011A & East & Shoulder & 52.80 & 32.10 & 1.10 & 13.0 \\
\hline & FS04WV025011BA & East & Shoulder & 24.83 & 29.30 & 0.60 & 7.2 \\
\hline & FS04WV025011Bt & East & Shoulder & & & & 6.8 \\
\hline \multirow[t]{2}{*}{98} & FS04WV025012A & East & Bench & 10.60 & 25.30 & 0.30 & 5.3 \\
\hline & FS04WV025012BW & East & Bench & 6.98 & 13.10 & 0.40 & 5.3 \\
\hline \multirow[t]{3}{*}{99} & FS04WV025013A & East & Ridge & 40.67 & 6.00 & 4.40 & 29.5 \\
\hline & FS04WV025013BA & East & Ridge & 18.44 & 28.70 & 0.40 & 4.3 \\
\hline & FS04WV025013Bt & East & Ridge & & & & 2.7 \\
\hline \multirow[t]{3}{*}{99} & FS04WV025014A & East & Back slope & 86.52 & 28.50 & 2.00 & 12.6 \\
\hline & FS04WV025014BA & East & Back slope & 19.34 & 27.50 & 0.50 & 5.8 \\
\hline & FS04WV025014Bt & East & Back slope & & & & 6.7 \\
\hline \multirow[t]{2}{*}{100} & FS04WV025015A & East & Shoulder & 18.79 & 17.10 & 0.70 & 9.7 \\
\hline & FS04WV025015Bt & East & Shoulder & 6.62 & 36.00 & 0.10 & 2.4 \\
\hline \multirow[t]{3}{*}{100} & FS04WV067008A & West & Foot & 71.37 & 21.80 & 2.20 & 13.0 \\
\hline & FS04WV067008BA & West & Foot & 188.85 & 1.60 & & 5.1 \\
\hline & FS04WV067008Bw & West & Foot & & & & 4.9 \\
\hline \multirow[t]{3}{*}{101} & FS04WV067009A & West & Floodplain & 10.23 & 7.80 & 0.90 & 17.6 \\
\hline & FS04WV067009BA & West & Floodplain & 6.60 & 16.30 & 0.30 & 10.4 \\
\hline & FS04WV067009Bg & West & Floodplain & & & & 8.7 \\
\hline \multirow[t]{3}{*}{101} & FS04WV067010A & West & Back slope & 47.67 & 18.60 & 1.70 & 18.6 \\
\hline & FS04WV067010BA & West & Back slope & 22.18 & 8.60 & 1.70 & 14.1 \\
\hline & FS04WV067010Bw & West & Back slope & & & & 15.0 \\
\hline \multirow[t]{2}{*}{102} & FS04WV067011BA & West & Floodplain & 23.10 & 17.50 & 0.90 & 12.3 \\
\hline & FS04WV067011Bw & West & Floodplain & 8.95 & 15.70 & 0.40 & 9.5 \\
\hline \multirow[t]{3}{*}{102} & FS04WV067012A & West & Ridge & 29.68 & 24.10 & 0.80 & 12.5 \\
\hline & FS04WV067012BA & West & Ridge & 18.77 & 25.00 & 0.50 & 7.7 \\
\hline & FS04WV067012Bw & West & Ridge & & & & 6.4 \\
\hline
\end{tabular}




\begin{tabular}{|c|c|c|c|c|c|c|c|}
\hline $\begin{array}{l}\text { Descrip. } \\
\text { Page \# }\end{array}$ & Sample ID & $\begin{array}{l}\text { Wshed } \\
\text { Area }\end{array}$ & $\begin{array}{l}\text { Landscape } \\
\text { Position }\end{array}$ & $\begin{array}{c}\mathrm{Ca} \\
\mathrm{mg} / \mathrm{kg}\end{array}$ & $\begin{array}{c}\mathrm{Al} \\
\mathrm{mg} / \mathrm{kg}\end{array}$ & $\begin{array}{l}\text { Ca:Al } \\
\text { Ratio }\end{array}$ & $\begin{array}{c}\text { BSECEC } \\
\% \\
\end{array}$ \\
\hline \multirow[t]{3}{*}{103} & FS04WV067013A & West & Back slope & 22.48 & 17.10 & 0.90 & 15.0 \\
\hline & FS04WV067013BA & West & Back slope & 6.59 & 8.80 & 0.50 & 7.5 \\
\hline & FS04WV067013Bw & West & Back slope & & & & 6.9 \\
\hline \multirow[t]{3}{*}{103} & FS04WV067014A & West & Bench & 63.22 & 7.20 & 5.80 & 29.8 \\
\hline & FS04WV067014BA & West & Bench & 33.67 & 11.90 & 1.90 & 11.1 \\
\hline & FS04WV067014Bw & West & Bench & & & & 8.6 \\
\hline \multirow[t]{3}{*}{104} & FS04WV067015A & West & Shoulder & 64.05 & 15.90 & 2.70 & 17.6 \\
\hline & FS04WV067015BA & West & Shoulder & 31.36 & 21.40 & 1.00 & 10.7 \\
\hline & FS04WV067015Bw & West & Shoulder & & & & 9.0 \\
\hline \multirow[t]{3}{*}{104} & FS04WV067016A & West & Ridge & 33.32 & 8.80 & 2.50 & 23.6 \\
\hline & FS04WV067016BA & West & Ridge & 15.75 & 11.20 & 0.90 & 9.6 \\
\hline & FS04WV067016Bt & West & Ridge & & & & 6.1 \\
\hline \multirow[t]{3}{*}{105} & FS04WV025016A1 & East & Floodplain & 38.33 & 16.90 & 1.50 & 11.9 \\
\hline & FS04WV025016A2 & East & Floodplain & 21.07 & 41.80 & 0.30 & 3.8 \\
\hline & FS04WV025016Bw & East & Floodplain & & & & 2.1 \\
\hline \multirow[t]{3}{*}{105} & FS04WV025017A & East & Back slope & 72.89 & 32.10 & 1.50 & 11.1 \\
\hline & FS04WV025017BA & East & Back slope & 8.08 & 43.60 & 0.10 & 2.9 \\
\hline & FS04WV025017Bt & East & Back slope & & & & 3.4 \\
\hline \multirow[t]{2}{*}{106} & FS04WV025018A & East & Foot & 9.96 & 25.40 & 0.30 & 6.4 \\
\hline & FS04WV025018Bw & East & Foot & 9.48 & 32.90 & 0.20 & 2.7 \\
\hline \multirow[t]{3}{*}{106} & FS04WV067018A & West & Foot & 43.45 & 19.40 & 1.50 & 13.6 \\
\hline & FS04WV067018BA & West & Foot & 11.56 & 16.50 & 0.50 & 6.4 \\
\hline & FS04WV067018Bt & West & Foot & & & & 5.7 \\
\hline \multirow[t]{3}{*}{107} & FS04WV067019A & West & Bench & 16.74 & 12.90 & 0.90 & 14.3 \\
\hline & FS04WV067019BA & West & Bench & 10.51 & 18.70 & 0.40 & 6.5 \\
\hline & FS04WV067019Bw & West & Bench & & & & 6.2 \\
\hline \multirow[t]{3}{*}{107} & FS04WV067020A & West & Shoulder & 12.34 & 16.20 & 0.50 & 10.4 \\
\hline & FS04WV067020BA & West & Shoulder & 6.36 & 24.50 & 0.20 & 5.2 \\
\hline & FS04WV067020Bt & West & Shoulder & & & & 7.8 \\
\hline \multirow[t]{3}{*}{108} & FS04WV067021A & West & Ridge & 20.05 & 13.90 & 1.00 & 14.8 \\
\hline & FS04WV067021BA & West & Ridge & 24.71 & 14.00 & 1.20 & 11.2 \\
\hline & FS04WV067021Bw & West & Ridge & & & & 6.7 \\
\hline
\end{tabular}




\begin{tabular}{|c|c|c|c|c|c|c|c|}
\hline $\begin{array}{l}\text { Descrip. } \\
\text { Page \# }\end{array}$ & Sample ID & $\begin{array}{l}\text { Wshed } \\
\text { Area }\end{array}$ & $\begin{array}{l}\text { Landscape } \\
\text { Position }\end{array}$ & $\begin{array}{c}\mathrm{Ca} \\
\mathrm{mg} / \mathrm{kg}\end{array}$ & $\begin{array}{c}\mathrm{Al} \\
\mathrm{mg} / \mathrm{kg}\end{array}$ & $\begin{array}{l}\text { Ca:Al } \\
\text { Ratio }\end{array}$ & $\begin{array}{c}\text { BSECEC } \\
\%\end{array}$ \\
\hline \multirow[t]{3}{*}{108} & FS04WV067022A1 & West & Shoulder & 13.29 & 7.50 & 1.20 & 17.5 \\
\hline & FS04WV067022A2 & West & Shoulder & 2.99 & 7.00 & 0.30 & 6.9 \\
\hline & FS04WV067022AB & West & Shoulder & & & & 6.0 \\
\hline \multirow[t]{3}{*}{109} & FS04WV067023A & West & Ridge & 12.39 & 19.70 & 0.40 & 10.0 \\
\hline & FS04WV067023BA & West & Ridge & 7.79 & 28.30 & 0.20 & 5.3 \\
\hline & FS04WV067023Bw & West & Ridge & & & & 4.9 \\
\hline \multirow[t]{2}{*}{109} & FS04WV067024BA & West & Back slope & 24.99 & 33.80 & 0.50 & 9.4 \\
\hline & FS04WV067024Bt & West & Back slope & 10.58 & 26.00 & 0.30 & 6.9 \\
\hline \multirow[t]{3}{*}{110} & FS04WV025020A & East & Bench & 64.11 & 12.10 & 3.50 & 19.9 \\
\hline & FS04WV025020BA & East & Bench & 15.98 & 15.50 & 0.70 & 9.2 \\
\hline & FS04WV025020Bt & East & Bench & & & & 7.2 \\
\hline \multirow[t]{3}{*}{110} & FS04WV025021A & East & Back slope & 49.63 & 10.70 & 3.10 & 16.2 \\
\hline & FS04WV025021BA & East & Back slope & 25.58 & 32.50 & 0.50 & 6.2 \\
\hline & FS04WV025021BW & East & Back slope & & & & 4.9 \\
\hline \multirow[t]{3}{*}{111} & FS04WV101002A & East & Ridge & 92.21 & 30.90 & 2.00 & 15.7 \\
\hline & FS04WV101002BA & East & Ridge & 87.67 & 19.80 & 2.90 & 15.7 \\
\hline & FS04WV101002Bt & East & Ridge & & & & 17.2 \\
\hline \multirow[t]{3}{*}{111} & FS04WV067025A & West & Ridge & 12.93 & 40.60 & 0.20 & 5.9 \\
\hline & FS04WV067025BA & West & Ridge & 2.31 & 24.90 & 0.10 & 5.4 \\
\hline & FS04WV067025Bw & West & Ridge & & & & 3.6 \\
\hline \multirow[t]{3}{*}{112} & FS04WV067026A & West & Ridge & 18.17 & 25.60 & 0.50 & 7.1 \\
\hline & FS04WV067026BA & West & Ridge & 14.98 & 41.00 & 0.20 & 4.3 \\
\hline & FS04WV067026Bw & West & Ridge & & & & 4.4 \\
\hline \multirow[t]{3}{*}{112} & FS04WV067027A & West & Shoulder & 30.75 & 27.90 & 0.70 & 6.9 \\
\hline & FS04WV067027BA & West & Shoulder & 9.88 & 23.70 & 0.30 & 5.1 \\
\hline & FS04WV067027Bt & West & Shoulder & & & & 7.5 \\
\hline \multirow[t]{3}{*}{113} & FS04WV067028A1 & West & Back slope & 15.99 & 16.10 & 0.70 & 9.4 \\
\hline & FS04WV067028A2 & West & Back slope & 16.91 & 18.90 & 0.60 & 7.4 \\
\hline & FS04WV067028Bw & West & Back slope & & & & 6.0 \\
\hline \multirow[t]{3}{*}{113} & FS04WV067029A & West & Back slope & 26.15 & 31.80 & 0.50 & 7.7 \\
\hline & FS04WV067029BA & West & Back slope & 13.92 & 15.20 & 0.60 & 6.8 \\
\hline & FS04WV067029Bw & West & Back slope & & & & 7.7 \\
\hline
\end{tabular}




\begin{tabular}{|c|c|c|c|c|c|c|c|}
\hline $\begin{array}{l}\text { Descrip. } \\
\text { Page \# }\end{array}$ & Sample ID & $\begin{array}{l}\text { Wshed } \\
\text { Area }\end{array}$ & $\begin{array}{l}\text { Landscape } \\
\text { Position }\end{array}$ & $\begin{array}{c}\mathrm{Ca} \\
\mathrm{mg} / \mathrm{kg}\end{array}$ & $\begin{array}{c}\mathrm{Al} \\
\mathrm{mg} / \mathrm{kg}\end{array}$ & $\begin{array}{l}\text { Ca:Al } \\
\text { Ratio }\end{array}$ & $\begin{array}{c}\text { BSECEC } \\
\%\end{array}$ \\
\hline \multirow[t]{3}{*}{114} & FS04WV067030A & West & Bench & 156.00 & 6.20 & 16.50 & 36.3 \\
\hline & FS04WV067030BA & West & Bench & 61.16 & 13.40 & 3.00 & 12.7 \\
\hline & FS04WV067030Bt & West & Bench & & & & 9.7 \\
\hline \multirow[t]{3}{*}{114} & FS04WV067031A & West & Bench & 15.66 & 14.20 & 0.70 & 11.9 \\
\hline & FS04WV067031BA & West & Bench & 17.80 & 20.70 & 0.60 & 6.2 \\
\hline & FS04WV067031Bw & West & Bench & & & & 5.8 \\
\hline \multirow[t]{2}{*}{115} & FS04WV067032A & West & Foot & 66.30 & 16.30 & 2.70 & 13.7 \\
\hline & FS04WV067032Bt & West & Foot & 9.03 & 19.10 & 0.30 & 5.2 \\
\hline \multirow[t]{3}{*}{115} & FS04WV025023A & East & Shoulder & 40.43 & 33.20 & 0.80 & 6.5 \\
\hline & FS04WV025023BA & East & Shoulder & 23.16 & 36.40 & 0.40 & 5.0 \\
\hline & FS04WV025023Bt & East & Shoulder & & & & 4.5 \\
\hline \multirow[t]{3}{*}{116} & FS04WV025024A & East & Back slope & 7.66 & 21.80 & 0.20 & 6.2 \\
\hline & FS04WV025024BA & East & Back slope & 9.39 & 28.00 & 0.20 & 3.8 \\
\hline & FS04WV025024Bw & East & Back slope & & & & 4.4 \\
\hline \multirow[t]{3}{*}{116} & FS04WV025025A & East & Bench & 13.95 & 25.30 & 0.40 & 5.9 \\
\hline & FS04WV025025BA & East & Bench & 8.30 & 40.70 & 0.10 & 3.9 \\
\hline & FS04WV025025Bt & East & Bench & & & & 3.9 \\
\hline \multirow[t]{3}{*}{117} & FS04WV067033A1 & East & Floodplain & 10.23 & 22.20 & 0.30 & 8.4 \\
\hline & FS04WV067033A2 & East & Floodplain & 15.87 & 42.20 & 0.20 & 5.3 \\
\hline & FS04WV067033BA & East & Floodplain & & & & 5.4 \\
\hline \multirow[t]{3}{*}{117} & FS04WV067034A & East & Back slope & 28.93 & 17.60 & 1.10 & 4.8 \\
\hline & FS04WV067034BA & East & Back slope & 10.63 & 36.10 & 0.20 & 3.9 \\
\hline & FS04WV067034Bt & East & Back slope & & & & 5.5 \\
\hline \multirow[t]{3}{*}{118} & FS04WV101003A & East & Back slope & 23.98 & 6.90 & 2.30 & 16.4 \\
\hline & FS04WV101003BA & East & Back slope & 14.21 & 23.80 & 0.40 & 9.2 \\
\hline & FS04WV101003Bt & East & Back slope & & & & 7.5 \\
\hline \multirow[t]{3}{*}{118} & FS04WV101004A & East & Ridge & 23.93 & 20.80 & 0.80 & 9.3 \\
\hline & FS04WV101004BA & East & Ridge & 16.69 & 43.90 & 0.30 & 4.6 \\
\hline & FS04WV101004Bt & East & Ridge & & & & 4.6 \\
\hline \multirow[t]{3}{*}{119} & FS04WV101005A1 & East & Bench & 37.47 & 32.32 & 0.77 & 9.2 \\
\hline & FS04WV101005A2 & East & Bench & 15.71 & 37.14 & 0.28 & 5.0 \\
\hline & FS04WV101005Ab & East & Bench & & & & 6.4 \\
\hline
\end{tabular}




\begin{tabular}{llllcccc}
\hline $\begin{array}{l}\text { Descrip. } \\
\text { Page \# }\end{array}$ & Sample ID & $\begin{array}{l}\text { Wshed } \\
\text { Area }\end{array}$ & $\begin{array}{l}\text { Landscape } \\
\text { Position }\end{array}$ & $\begin{array}{c}\text { Ca } \\
\mathbf{m g} / \mathbf{k g}\end{array}$ & $\begin{array}{c}\text { Al } \\
\mathbf{m g} / \mathbf{k g}\end{array}$ & $\begin{array}{c}\text { Ca:Al } \\
\text { Ratio }\end{array}$ & $\begin{array}{c}\text { BSECEC } \\
\text { \% }\end{array}$ \\
\hline 119 & FS04WV101006A & East & Bench & 38.27 & 44.53 & 0.57 & 8.5 \\
\hline & FS04WV101006BA & East & Bench & 19.10 & 36.27 & 0.35 & 5.6 \\
\hline & FS04WV101006Bt & East & Bench & & & & 6.9 \\
\hline 120 & & & & & & & \\
\hline & FS04WV025026A & East & Foot & 46.96 & 25.30 & 1.20 & 10.7 \\
\hline & FS04WV025026BA & East & Foot & 6.36 & 41.00 & 0.10 & 2.8 \\
\hline & FS04WV025026Bt & East & Foot & & & & 3.2 \\
\hline 120 & FS04WV025027A & East & Foot & 44.90 & 38.60 & 0.80 & 8.6 \\
\hline & FS04WV025027BA & East & Foot & 89.08 & 17.90 & 3.30 & 4.5 \\
\hline & FS04WV025027Bt & East & Foot & & & & 4.3 \\
\hline 121 & & & & & & & \\
\hline & FS04WV025022A & East & Ridge & 109.22 & 16.50 & 4.40 & 28.4 \\
\hline
\end{tabular}

